Reading in changing society

\begin{tabular}{l|l} 
Edited by \\
Marju Lauristin and Peeter Vihalemm
\end{tabular} 
Reading in changing society 
STUDIES IN READING AND BOOK CULTURE 2 


\title{
Reading in changing society
}

\author{
Edited by \\ Marju Lauristin and Peeter Vihalemm
}




\section{STUDIES IN READING AND BOOK CULTURE 2}

Reading in changing society

Edited by Marju Lauristin and Peeter Vihalemm

Tartu 2014

Publication of this book has been financed by Estonian Science Foundation grant 8329 .

Language editors: Juta Ristsoo and Lili Pilt

Cover design: Kalle Paalits

ISSN 2382-6673 (print)

ISSN 2382-6746 (pdf)

ISBN 978-9949-32-575-7 (print)

ISBN 978-9949-32-578-8 (pdf)

Copyright: University of Tartu, authors, 2014

University of Tartu Press

www.tyk.ee 


\section{Contents}

Marju Lauristin, Peeter Vihalemm

Introduction

\section{BOOKS AND READING CULTURE}

Ilkka Mäkinen

Reading like monks: The death or survival of the love of reading? ...

Kurmo Konsa, Edith Hermann

The logic of text and structure of books: Changing the functions

\section{BOOKS AND READERS}

Peeter Vihalemm

Changes in the character of book consumption in Estonia, 1979-2011

\section{Marju Lauristin}

Reading as lifestyle

Mara Grudule, Ojars Lams

Reader in the clash of cultures: Experience in Eastern Latvia

(Latgale cultural region) 2009-2011

\section{READING IN THE DIGITAL AGE}

\section{Juha Herkman, Eliisa Vainikka}

'New reading' or communication? Finnish students as readers in the age of social media 
Skans Kersti Nilsson

Reading in a changing society: Some impact in the Swedish context

\section{READING POLICIES}

Krista Lepik

Reading policy and public libraries in Estonia - from the perspective of Foucauldian analytics of governmentality

Mats Dolatkhah, Anna Hampson Lundh

Reading, democracy and discipline: Premises for reading activities in Swedish primary schools from 1967 to 1969

Asko Tamme

Library lists and directed reading. Some episodes

in the history of Estonian libraries

Helin Puksand

The reading preferences of Estonian adolescents

\section{LIBRARY PRACTICES AND EXPERIENCES}

\section{Olga Einasto}

"The time is out of joint": A postmodern approach to library

\section{Triinu Seppam}

E-books in the Tallinn Central Library: First experiences

\section{Krista Kiisa}

Exciting reading from the past: Archiving and usability

of the periodicals stored in the digital collections

of the National Library of Estonia

\section{Ilona Smushkina, Elena Sipria-Mironov}

Prima Vista Literary Festival: The message delivered by libraries in space and time 


\title{
Introduction
}

\author{
Marju Lauristin, Peeter Vihalemm
}

The changing state of reading and its fate in the digitalised world is one of the core issues in the contemporary debates about the future of culture. The central position of the printed word, and primarily, books as the most valuable cultural medium and the main source of knowledge, are becoming questioned in the age of the Internet. Reading as gateway to the world of fantasies has been challenged by powerful audiovisual media. Is the pleasure of reading as a creative process involving imagination and self-cognition disappearing, and being replaced by the quick exchange of impressions and images in social media? Are these critical notes and concerns about the future of reading just rapid generalisations and misunderstandings, evoked by the invasion of new technologies in the old and well-established world of books? Or are there more serious reasons for speaking about the cultural changes occurring not only in the world of books, libraries and classrooms, but also in the 'real world' of politics, economics and the practical everyday life of people?

These issues were discussed during the Baltic-Nordic conference called Reading in a Changing Society organised by the Institute of Journalism, Communication and Information Studies of the University of Tartu and by the University of Tartu Library on 31 October to 1 November 2013. Some of these discussions are reflected in this collection of articles, which are based on the conference papers.

The articles represent empirical studies, theoretical and historical reflections on the changes in the world of books and reading in the Baltic and Nordic countries, as well as descriptions of the new library practices that reflect the creative efforts to adapt to the changing social and technological environment. Looking at the diversity of the content and approaches, the book is divided into five sections: Books and Reading Culture, Books and Readers, Reading in the Digital Era, Reading Policies, and Library Practices and Experiences.

Contemplating the current trends in reading culture, in the opening article 'Reading like monks: Death or survival of the love of reading?', Ilkka Mäkinen asks if the traditional love of reading, with the reader immersed in the world 
of a long text, is dying in the contemporary world? He emphasises that this is not the first time that we have faced a crisis in reading. He seeks parallels for today's situation in the history of reading, and asks what lessons we can learn from this.

The article by Kurmo Konsa and Edith Herman 'The logic of text and structure of books: Changing the function' focuses on the conceptualisation of the changes in the informational structure of books in contemporary society. The authors distinguish three different informational levels of books: structural properties, functional properties, and the context of books, which are changing in time, especially as the traditional communicative functions of books are being co-opted by electronic media.

The second section of the book presents the results of empirical research on book consumption and readers. Peeter Vihalemm's article 'Changes in the character of book consumption in Estonia, 1979-2011' investigates how the level and character of book consumption has changed in Estonia over last 30 years, based mainly on the results of representative sociological surveys conducted by the Institute of Journalism and Communication at the University of Tartu. A survey is provided of the very active book buying and reading of Estonians in the 1970s and 1980s; the sharp decline after the restoration of independence in 1991; and the contemporary trends until 2011. The article provides some explanations for these changes - after the restoration of independence and the establishment of 'normal capitalism', and the emergence of an information and consumer society, cultural mechanisms were activated that had characterised the Western countries for 30 years - a strong differentiation between elite culture and popular culture, and a general decline in book demand.

Marju Lauristin's article 'Reading as lifestyle' is also based on the redults of sociological surveys conducted by the Institute of Journalism and Communication at the University of Tartu. The analysis is inspired by Pierre Bourdieu's understanding of social and cultural stratification and by the analysis of patterns of cultural consumption in contemporary UK by Tony Bennett et al (2009). In Lauristin's analysis of the empirical data about the linkages between book consumption and more general lifestyle characteristics, she has applied similar multidimensional approach to the cultural field, comparing the levels of active cultural participation and selectivity of book preferences with the status- and gender-related patterns of lifestyles, as well as with generational differences. The article presents the results of the factor analysis of book preferences and the typology of reading-related lifestyles, also a comparison of the structures of reading-related lifestyles in 1990 and 2011. One of general conclusions of this comparison is that, despite the overall decline in the average amount of reading in Estonian society after the 1990s, the structure of readingrelated lifestyles has not radically changed, but has become more diverse and gender-balanced. 
Mara Grudule and Ojars Lams's article 'Reader in the clash of cultures: Experience in Eastern Latvia (Latgale cultural region) 2009-2011' introduces Latgale as one of four historical and cultural regions of Latvia with a large number of Russian speakers. Although most of the population today speaks Latvian and/or Russian, the region can be characterised by strong Latgallian cultural traditions. The article is based on a three-year expedition in three districts of Latgale and on the observational data gathered about the book and periodical reading interests of the local population, their language abilities, home libraries, literary taste, etc.

The third section of this volume analyses the impact of digitalisation on the young generation's reading habits and preferences. The article by Juha Herkman and Eliisa Vainikka entitled "New reading' or communication? Finnish students as readers in the age of social media' investigates how the idea of the 'digital revolution' challenges contemporary conceptions of reading. This article explores the contemporary media use and reading habits of Finnish students, who can be described as representatives of the 'Net Generation'. However, the analysis is focused on the older age group of students, aged between 18 and 30, who can be seen as a transition group between the younger 'digital natives' born with social and ubiquitous media and the older generations of 'digital immigrants', more familiar with print and broadcast media. The information presented in the article, based on the results of an empirical study, confirms this assumption. Although young adults spend a lot of time with short text forms for interpersonal and peer communication, they have not abandoned the reading of professionally produced texts, and still appreciate printed text forms, especially books.

Skans Kersti Nilsson's article 'Reading in a changing society: Some impact in the Swedish context' focuses on how young Swedish adults, 15 to 25 years old, express their thoughts on reading narrative fiction in printed books and in digitised formats. Nine focus groups were conducted, which were comprised of students from the theoretical and practical classes in upper secondary school and pupils from the folk high school. A kind of consensus in defence of reading printed books was evident. The results showed that digital reading does not pose a threat to reading narratives in printed books, and books as artefacts are not threatened by e-books.

The fourth section of the anthology is related to the reading policies in different societies at various times. Krista Lepik's starting point is the Foucauldian analysis of governmentality, which she used to analyse the present-day controversies in Estonian cultural policy. Her article 'Reading policy and public libraries in Estonia - from the perspective of Foucauldian analytics of governmentality' discusses the role of Estonian public libraries as facilitators and promoters of 
readership and questions the intervention of the state into an intimate sphere like the reader-book relationship. Since 2012, the Ministry of Culture has issued lists of 'officially favoured literature' to instruct professionals in public libraries regarding the purchase of books for the funds allocated by the state. The issue of spending the taxpayers' money effectively may have an impact that reaches far beyond the calculations in the cultural budget. The forcible enactment of a reading policy that only considers a few circumstances (cost benefit, national aims, etc.) may potentially be at cross purposes with its goals. As such, the idea of promoting best works of Estonian writers to Estonian readers may be a good cause, but the implementation of this idea can be questioned and serve as a lesson for similar enterprises in the future.

The article by Mats Dolatkhah and Anna Hampson Lundh, entitled 'Reading, democracy and discipline: Reading practices in Swedish primary school classrooms 1967-1969', provides an interesting historical parallel with the contemporary efforts of the Estonian government to control the reading tastes of the public. The article reports on an ongoing research project investigating the reading culture in Sweden after World War II. The project is based on a large collection of sound and video recordings made in Swedish primary school classrooms in 1967 and 1969. Sweden established a system of nineyear comprehensive and compulsory primary schooling, including the teaching of reading, in 1962. The main mission of this new system was to foster an independent, democratic citizenry, but recent research in educational history has suggested that it also developed a subtle, sophisticated and far-reaching disciplinary regime. However, research often assumes that the promotion of reading among children and young people works best if a voluntary spirit and individual freedom prevail in connection with the reading activities, and a feeling of compulsion is avoided. In upcoming papers, the authors will explore the reading practices as they were enacted and the field of tensions that exist between the institutional ideologies of the new comprehensive school system, and the children and teachers as individuals in particular situations.

In his article, 'Library lists and directed reading. Some episodes in the history of Estonian libraries', Asko Tamme's aim is to analyse the role of lists of recommended reading in Estonian librarianship, starting with the list published in the weekly newspaper Olevik in 1882 and ending with the introduction of systematically prepared lists in the late 1920s. The author is interested in the triangular power relations between the state/public sphere, libraries and reading. The author's hypothesis is that an analysis of the introductory and explanatory texts included with the recommended reading lists provide enough information to describe the general framework of the views, expectations and presumptions of the different parties, the functional forms they have taken, and the dynamics inside the triangular power scheme.

Helin Puksand's article 'The reading preferences of Estonian adolescents' provides a brief survey of the empirical data related to the extracurricular 
reading habits and preferences of Estonian adolescents and confirms the educational importance of school reading lists. The results of the survey, which studied the reading preferences of students in the $9^{\text {th }}$ and $11^{\text {th }}$ grades were analysed in 2008 and 2009. The overwhelming favourite was Harry Potter by J. K. Rowling, but many books from the school reading lists were among the favourites: Truth and Justice (by A. H. Tammsaare), Crime and Punishment (by Fyodor Dostoyevsky), A Doll's House (by Henrik Ibsen), Anna Karenina (by Lev Tolstoy), Bye, Yellow Cat (a youth novel by Mati Unt), Eugene Onegin (by Alexander Pushkin), The Lord of the Flies (by William Golding), The Master of Kõrboja (by A. H. Tammsaare), and The Old Man and the Sea (by Ernest Hemingway).

The last section of this volume consists of four articles on library experiences and practices. Olga Einasto's article “"Time is out of joint”: A postmodern approach to libraries' stresses that the development of libraries has always been related to the evolution of data carriers. However, twice in history, this process has been revolutionary: in the $15^{\text {th }}$ century after the invention of the printing press, and in the $20^{\text {th }}$ century once information could be saved and accessed electronically. In our libraries today, modern principles (i.e. valuing and preserving the printed word, order in organising catalogues and collections) and postmodern principles (i.e. pluralism, variety, virtuality, disappearance of barriers, and the participation of the reader) have merged. A postmodern library is a creative mix of old and new, of tools and resources, which blends digital and printed books with staff expertise in new and ever-changing arrays.

Triinu Seppam's article 'E-books in the Tallinn Central Library: First experiences' describes the introduction of e-book lending at the Tallinn Central Library on 1 February 2012. Krista Kiisa's article 'Exciting reading from the past: archiving and usability of periodicals stored in the National Library of Estonia digital collections' describes the experience of working with current and old periodicals in the National Library, and disseminating their contents via the library's digital archive DIGAR. The rapid development of informational technology undoubtedly offers new directions for the development for libraries, but it also results in a need to find new ways of communicating with the potential readers. Ilona Smushkina and Elena Sipria-Mironov's article 'Literary Festival Prima Vista - The message delivered by libraries in space and time' describes the Prima Vista literary festival, which has been organised by the University of Tartu Library every spring since 2004.

The Baltic-Nordic comparisons presented in this book show that, despite the historical and political differences, many parallel developments exist that are related to the worlds of books and reading around the Baltic Sea. Some of these trends, which got their start in the Nordic countries already in 1960s and 1970s, 
have now also reached the other side of the Baltic Sea. Some of these trends are new and caused by the technological revolution, and this also affects the fate of books throughout Europe in quite a similar manner. 


\title{
I. BOOKS AND READING CULTURE
}

\section{Reading like monks: The death or survival of the love of reading?}

\author{
Ilkka Mäkinen
}

\section{Introduction}

Reading as a spontaneous, sustained and everyday activity is in danger, or so it is believed. Today's studies and news tell us that the young generation, especially boys and young men, do not read long texts for pleasure (e.g. Northern Light on PISA 2009), even if they otherwise use and produce more text than ever.

My aim in this article is to seek historical parallels for today's reading situation. I believe that a better understanding of the historical development of reading can help us place the present situation in a broader context. Even if we believe that history does not repeat itself, historical parallels do bring forth potential scenarios. When we know what has happened before, we can act consciously, or at least, set unnecessary worries aside.

The aim of this article is to make the historical character of the European reading culture more intelligible; especially when it comes to one of its important elements, the supposition that the love of reading exists. In this article I will present a general picture of the historical development of reading, while a more detailed documentation will have to wait for the completion of future studies. When we understand that, among many other things, the love of reading is a historical construction, which has a beginning and development, and which is now on a threshold of something new, we can get a more constructive perspective on the future development of reading, which is currently unfolding. Of course, the thoughts that I will present about the future of reading are more speculative in nature.

There are many types of reading today, but two types deserve special attention. One is a functional, utilitarian type of reading that strives for an efficient acquisition of information. In fact, the goal of this type of reading is to read as little as possible in relation to the desired effects. Modern media is full of small bits of information that can be sought and constructed into new texts 
to be used in social communication, work and entertainment. Today's typical reader has no patience for spending too much time on texts that exceed the length of an average Wikipedia entry. The other type, which still exists, but is perhaps declining, is more non-utilitarian. The reader is immersed in the world of a long text, typically a thick novel. One starts on page one and continues reading a linear narrative that totally absorbs his or her mind until the end of the story. The reader loves reading and wants to read as much as possible, if the narrative appeals to him or her. Many of us are afraid that this kind of engaged reading of extensive printed texts with complex narratives, which is motivated by love of reading, is vanishing.

However, this is not the first time we are facing this kind of crisis in reading. A striking example is the antagonism between the scholastic way of reading and monastic reading in the Late Middle Ages. Scholars and students in the scholastic universities that were developing the Late Middle Ages - from the beginning of the second millennium onwards - typically read compilations, i.e., collections of text snippets from the church fathers, Aristotle and other authoritative authors. Reading whole texts from beginning to end was rare in the scholarly world. There was no need for a love of reading; the important thing was to analyse the text and use it for critical discussions. (Hamesse 1999)

But the love of reading existed elsewhere, in the monasteries. Monks, often hermits, were engrossed in the reading of the Bible, the writings of the church fathers, and other spiritual books. They chewed, swallowed, digested, and recited the texts. They had an emotional relationship with the texts, and they had a love of reading.

\section{The intensification of the European discourse on the love of reading}

In order to build a theoretical context for what I am going to say, I will briefly describe the larger research project, of which the present article is a part. Since, in another article, I have more thoroughly described the background of the European discourse on the love of reading, as well as the methods and results of my research (Mäkinen 2013a), here I will only present the general results necessary for understanding this article.

One of the crucial questions in the history of reading is whether it is possible to study how and why people really read in the past? Several methods are utilised to study the history of reading in order to penetrate the factual reality, the act and experience of reading, reading styles, genres and quantities, etc. The further back in history we go, the more serious the challenges become for this type of research, because the act or experience of reading often does not leave any visible traces. Another possibility is to study the ways in which reading is spoken about, i.e. the discourse on reading. There is no lack of discussions, opinions, laments, instructions, etc. on the subject of reading. 
To some extent, the discourse on reading reflects reality and the ways people really read. However, we must be critical of this information because speakers often set conscious or unconscious norms on how and what people are allowed to read. Therefore, we cannot always conclude what reading behaviour was actually like. However, the important aspect of the discourse on reading is that it expresses the presuppositions, conceptual structures and commitments that the speakers have adopted or accepted, often without realising it themselves. Those who discussed reading in the 18th century may have disagreed totally with each other on many details or principles in connection with reading, but they still shared important presuppositions or concepts about the essence, motivation and effects of reading.

In my doctoral thesis (1997), I studied how one of the central concepts connected to reading, namely the love of reading (lukuhalu in Finnish, läselust in Swedish), was adopted in the discourse on reading in Finland during the 18th and 19th centuries. The concept of the love of reading presumes that reading behaviour is guided by a spontaneous impulse, an inner drive, which can be enhanced or influenced by different actions, but which, in the end, is an unexplained force or drive in a human being. In Europe, the love of reading started to be discussed as a broad social phenomenon during the $18^{\text {th }}$ century.

Of course, other motives for reading exist as well, such as the rational interest in gaining knowledge and educating oneself. Work, status and the salvation of the soul are strong incentives for reading, and are often present when reading is talked about. The love of reading as an alleged motive for reading differs from the other incentives because there is no clear goal for or legitimisation of reading other than personal desire, pleasure and entertainment. Of course, this has aroused suspicions and lots of discussion on the potential dangers and blessings of reading. In my dissertation I studied this discussion in the Finnish and Swedish context (Mäkinen 1997). The present article is part of my research project to study similar phenomena on a broader European scale.

During the 18 th century, a new, spontaneous, self-sustaining and extensive reading style seemed to spread like a contagion across all social and geographical boundaries. Reinhardt Wittmann compares the rapid proliferation of reading to a contagious disease that was spread by "a reading bug" starting from a single infection, which "quickly escalated into a collective "reading epidemic". Other terms used by Wittmann are "reading mania", "reading fashion" and "new desire for reading". (Wittmann 1999)

There has been a lively discussion among the historians of reading about whether a reading revolution occurred at the end of the $18^{\text {th }}$ century. This discussion started with Rolf Engelsing's hypothesis of a revolution of reading in Germany during the late $18^{\text {th }}$ century and early $19^{\text {th }}$ century (Engelsing 1961/1973, 1970/1973). Some scholars, the most notable of them being Robert Darnton, have criticized Engelsing's theory and claimed that no such revolution took place (Darnton 1988). Others, such as Reinhardt Wittmann (1999), 
have come to the conclusion that a revolution of reading was real, not only in Germany but in Europe generally.

Reading behaviour and motivation is described in the major European languages with phrases and terms that refer to crystallised concepts. The most frequently used terms that refer to a spontaneous motivation for reading are the following: goût de la lecture in French literature; love of reading, habit of reading, desire to read in English; and Leselust in German. By studying the frequency of these terms in printed texts it is possible to follow the quantitative development of the discourse on reading. Google Books, Europeana and other digital services provide millions of books, journals and newspapers for such a study.

French, English and German phrases denoting reading 1500-1830

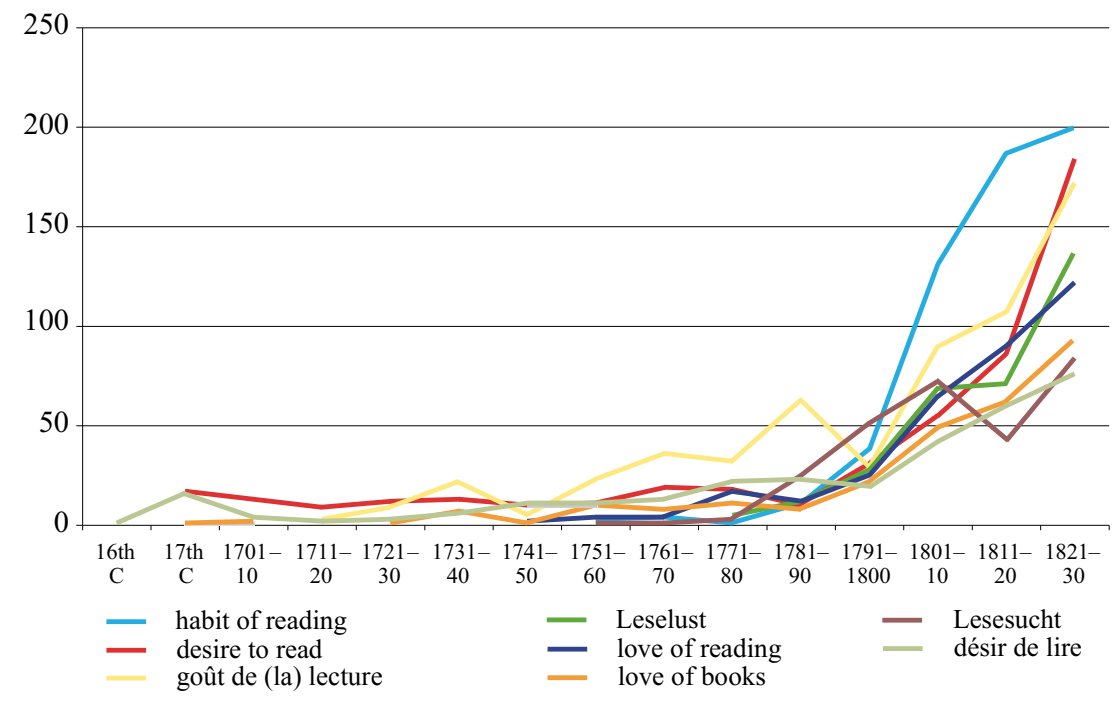

Figure 1. The occurrence of the French, English and German phrases meaning the love of reading (and equivalents) in 1500-1830. Data from Google Books.

Source: Mäkinen 2013a

The debate on the love of reading became tremendously intensified during the late 18 th century and early $19^{\text {th }}$ century. This supports the thesis that a reading revolution, or at least a revolution in the discourse related to the love of reading, did really occur (Mäkinen 2013a).

But the question remains: what caused the discourse on the love of reading? 


\section{Scholastic reading}

Let us take a closer look at the reading situation in the Late Middle Ages. At that time, he main characteristic related to reading was the scarcity of books. Every book had to be written by hand, which was expensive and time-consuming. Although some progress was made in replication techniques, such the pecia system, there was a serious bottleneck in the production of books, while the demand was growing rapidly as the result of the expansion of universities and other schools. There simply were not enough books at a reasonable price for every reader (Hamesse 1999, see also Friedenthal 2013)

On the other hand, the pedagogical methods also did not favour individual reading. The goal of learning was to collect useful arguments for scholastic argumentation. These were acquired, more or less, by rote learning. Both the lack of books and the characteristics of pedagogical and scientific practices favoured the use of compilations rather than the complete original texts. Compilations, where bits of text are taken out of their original context, do not make for very inspirational or spiritual reading. The analytic methods of scholasticism were well developed. Reading was a way to analyse the text, and tear it apart in order to use it in an oral discussion. It was necessary to find the useful parts of the texts quickly and easily.

A preliminary step was restructuring the text of the Bible, the basis of knowledge, in order to better manage the important information. The typography was refined and the text was organised in a more efficient way. The text was divided into more comprehensible and controllable sequences, paragraphs and verses, which were marked with numbers; chapters were given titles; concordances, tables of contents and alphabetical indexes were compiled (Hamesse 1999: 103-104).

The second step was producing abridgments and compilations chosen from the original theological and philosophical works. Most of the students, as well as many teachers and scholars, did not consult the original works when learning or teaching (Hamesse 1999: 113). The scholars wanted to use their time as effectively as possible. There was no point in recopying other people's works, when tools were available that made learning and remembering texts quick and easy, and helped you find the information you were looking for (ibidem).

Another reason for preferring compilations was that they ensured that the correct interpretation of the important texts would be hammered in the minds of the readers, who might draw the wrong conclusions if they read the original texts (ibidem: 116).

As Jacqueline Hamesse says, "In the Age of Scholasticism, the acquisition of knowledge became more important than the spiritual dimension of reading." (Hamesse 1999, 118). One could rephrase this as follows: The strictly utilitarian aspect of reading was preferred to more adventurous reading styles. If one only reads to find exactly what one is seeking, there is no need for a love of reading. In fact, the goal of rational reading is to read as little as possible. Once you have found what you're looking for, you can stop reading. In this case, 
reading is a function of information retrieval. The important thing is what we do with the acquired information in discussions and social media.

The scholastic type of reading is rational and controlled. The reader is always in charge of the situation. From this point of view the more engaged type of reading, which is characterised by a love of reading is suspicious, because when you innocently reads a narrative, you relinquish some of your self-determination and follow the path indicated by the text. It can lead you anywhere, and this is not rational. When you read the complete, original texts, you have to plough through long passages without exactly knowing what you are seeking, and you could find something that you had not been intentionally seeking. And, above all, time is being wasted.

\section{Monastic reading}

The scholastic way of reading was not originally the dominant one in the Christian world. We could say that scholastic reading was a novelty, an innovation, and the way of reading called monastic reading was more fundamental. The traditions of monastic reading dating from Christian Late Antiquity were "forgotten" during the Age of Scholasticism. These traditions were hibernating in the monasteries and were revived by the mystics of the High Middle Ages.

Jacqueline Hamesse provides a good characterisation of monastic reading (Hamesse 1999: 104), but the most extensive description and explanation can be found in the books by Jean Leclercq (especially: Leclercq 1993). He traces the ideals of monastic reading to the mystical views of St. Augustine and St. Gregory. St. Gregory seems to play an important role in the vocabulary that was later used to describe monastic reading (Leclercq 1993: 30).

While scholastic lectio (reading) was typically oriented towards quaestio (inquiry) and disputatio (discussion), or knowledge and science, monastic reading aspired to meditatio and oratio (prayer), or wisdom and appreciation (Leclercq 1993: 72). The relation of the monastic reader to the text was not detached and analytic, but close and rather physical, even muscular. It is often described with the word rumination: "It meant assimilating the content of a text by means of kind of mastication which releases its full flavour" (Leclercq 1993: 73). The reader is supposed to love what he is reading, taking the text into his heart and understanding its full meaning internally. "It means, as St. Augustine, St. Gregory, John of Fécamp, and others say in an untranslatable expression, to taste it with the palatum cordis or in ore cordis" (ibidem). The literal translation of palatum cordis might be something like the palate or taste of the heart, and ore cordis, the ear of the heart.

The monks' reading (lectio divina) was divided into two categories: lectio super mensam and lectio privata. Reading should never cease. That is why, when the monks gathered for a common meal, one of them stood at a pulpit and read aloud to the others. This is lectio super mensam (Negrone 1621) 
But the more typical, time-consuming reading (lectio privat), took place in the monks' cells. It was a continuous activity. It was done silently, but more often in a low voice, by muttering or murmuring the text. It was reading with passion, feeling the text affectively, because, after all, one was reading the Bible or another important text. There was an emotional relationship with the text. It was not extensive reading, but rather slow, repetitive, and contemplative reading. (Leclercq 1993)

It was essential that the monks read the original, unabbreviated works: the Bible, the books of the church fathers, and lives of the saints. New books were even created for this kind of reading. The most famous is Imitatio Christi by Thomas à Kempis, the masterpiece of medieval mysticism. Another work, lesser known outside Germany, was Die Theologia Deutsch or Der Frankfurter, presumably written in the $14^{\text {th }}$ century. It was first printed by Martin Luther (http://de.wikipedia.org/wiki/Theologia_deutsch).

When the ideals of monastic reading were explained, there were frequent references to St. Augustine and St. Gregory. Other representatives of Late Medieval mysticism were also mentioned especially St. Bernard of Clairvaux (1090-1153) and Bonaventura (1221-1274). Reading was associated with the mystic union between man, God and Christ.

For example Giulio Negrone, a Genoese Jesuit, cites Bonaventura: "In lectione itaque, si qua sibi permitti contigerit, non magis quarant scientiam, quam saporem." The goal of reading was not so much acquiring knowledge but the taste (sapor) of what one is reading. (Negrone 1621: 142)

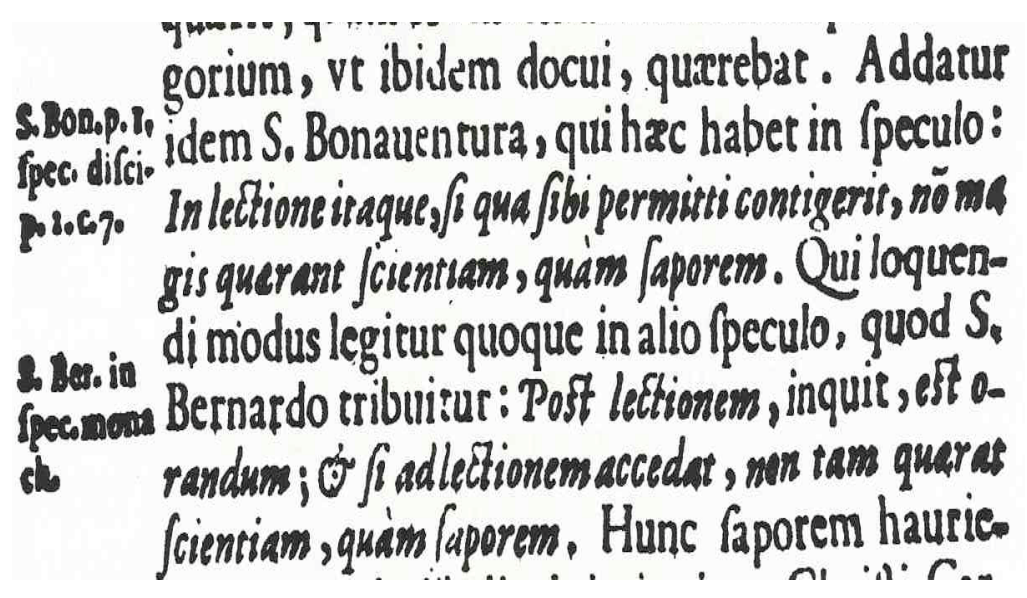

Negrone also uses the expression gustus lectionis spiritualis (taste of spiritual reading) to describe the proper attitude to reading (Negrone 1621: 144, the extracts are from the books digitised by Google Books): 


\section{De Leet.Libr.Spirit.Tr.V.}

attenti. Ex hac coniunctione oritur voluptas, fer delectatio. In guftu ipiri tualis lectionis, fapor eft, vt dixi, perfectio illa fuperioris ordinis, quę in verbis fentifque rerun facrarum ac diuinarum. ineit. Senfus interior, feu facultas eft palatum. cordis, quo corde fuperiorem anime partem inteflectu ac voluntate inftructam inteiligo, vt alibi probatum eft. Bona difpofitio palati huius eft 3 donum Sapientię. Doceor ab eodem Guilielmo,

When the mystics write about reading, their vocabulary is very corporeal.

\section{The Black Death and the renaissance of the love of reading}

As mentioned above, the scarcity of books in the Middle Ages was the dominant factor that influenced reading practices and the attitude toward reading. There were too many readers compared to the number of available books. A change in the situation was caused in a macabre way. The Black Death created havoc, especially in the European cities, where most of the readers, students and professors lived. After the catastrophic epidemic, more books were available for the surviving readers. Jacqueline Hamesse says: "Books were accessible again, and the university people, who had, to some extent, lost their taste for reading during the preceding century in their pursuit of a more utilitarian contact with knowledge, rediscovered reading." (Hamesse 1999: 119) Consequently, the humanists started to collect and search for classical texts, and reintroduce them into circulation. Printing was introduced in Europe in the middle of the $15^{\text {th }}$ century, which further increased the availability of books. During the Renaissance a more aesthetic relationship with literature also became apparent. Here and there, the practices of monastic reading started to be adopted by the lay people as well. (Hamesse 1999: 119)

\section{Reading becomes a tool in religious disputes}

Despite a certain rebirth in the individual love of reading after the Renaissance and the invention of printing, the number or people who were actively reading 
remained small. The Catholic Church did not favour the individual reading of the Bible, and was opposed to vernacular translations of the Sacred Scriptures. More secular reading was also not encouraged. The kind of rhetoric used to describe monastic reading was not intended for the masses. Until the beginning of the $16^{\text {th }}$ century, the discussion on the ideals and practices of reading was conducted in Latin.

A radical change occurred with the Reformation that increased individual reading in the $16^{\text {th }}$ century to a great extent. Martin Luther and other reformists stressed the need for everyone to personally acquaint themselves with the Holy Scriptures. For the first time, the Bible and other spiritual books were printed in the vernacular in large quantities. Reading became the centre of religious life, something that had previously not been true for common believers.

The Catholic Church felt threatened by the advances of the Reformation and launched a counterattack - the Counter-Reformation, which was supposed to support the inner religious life of the individual members of the church and their personal attachment to Catholic doctrine. This could be accomplished best by reading the appropriate books, and the Catholic Church started to massively distribute texts that supported its positions (Julia 1999). But there was one problem: how to make people read these texts, when the habit of individual reading had not previously been encouraged among the believers. The solution was simple: a love of reading had to be implanted in the people!

The Catholic clergy recommended religious reading in the vernacular to the members of the church. The ideals of this new reading were borrowed from the tradition of monastic reading. Here is a random example from France that was a very decisive battleground between the Reformation and the CounterReformation: Exhortations Monastiques du R. P. Estienne des Francois Xavier, Provincial des Carmes de la Providence de Touraine, sur la Regle de l'Ordre de la B. Heureuse Vierge Marie du Mont-Carmel, printed in 1687. It probably was meant for nuns, who could not read Latin.

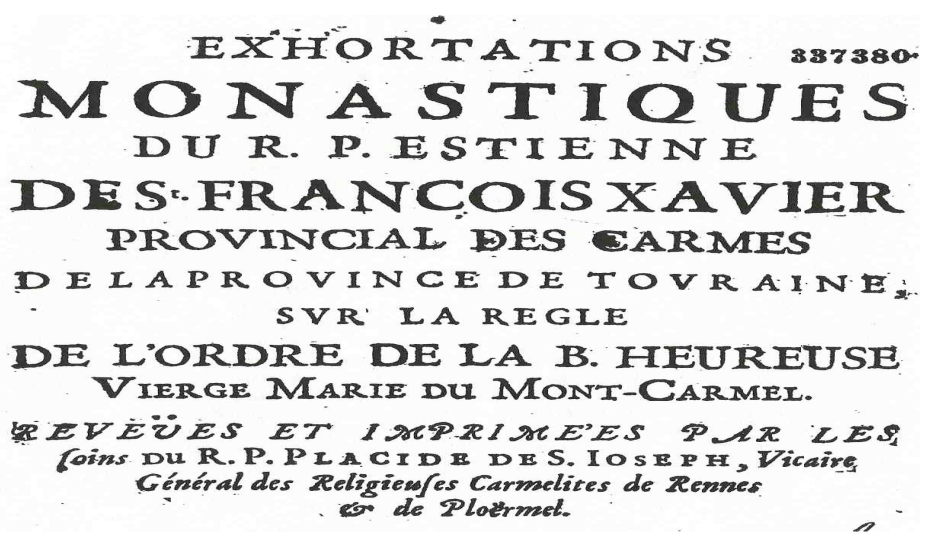


Again, the text contains references to and citations from medieval mystics, especially St. Bernard, but now the French text is most important: "Saint Bernard avoit cette pensee quand in disoit qu'en lisant if ne faut tant chercher la science \& la connoissance, qu'il faut désirer le goût, le sentiment \& la douceur intérieure. Si ad legendum accedat non tam quarat scientiam quam saporem." (Exhortations 1687: 355)

\section{pour le perfectionner. Saint Bernard avoit cette peñféé quand il difoit qu'en fifant il ne faut' pas taut chercher la fcience $\&$ la connoiffance, qu'il faut de. firer le goût, le fentiment \& la douceur intèrieure. Si ad legendum accedats son tam quarat fientiam quam faporem.}

In this way the rhetoric of the love of reading began to migrate from Latin into French and other vernacular languages.

The dilemma of the Counter-Reformation was that once people started reading, there was risk that they would read things that weren't appropriate for them (even Martin Luther and the other Reformists were aware of this risk, see Gilmont 1999). The Bible itself contains much that was seen as dangerous for an uneducated, uncontrolled reader, and the same applied to other books. Therefore, meetings of the clergy were organised to formulate instructions for the readers. Such meetings took place in Paris in 1713 and 1714. The results of the discussion at the meeting were printed in 1714 as Délibérations de l'Assemblée des Cardinaux, Archévêques et Évêques, Tenue à Paris en l'Année 1713 \& 1714. Sur l'acceptation de la Constitution en forme de Bulle de Nostre Saint Père le Pape Clément XI (Paris 1714).

\section{DELIBERATIONS}

DE L'ASSEMBLE'E DES CARDINAUX, ARCHEVEQUES ET EVEQUES, Tonué a Paris en 1 Annec 1713 . \& $17 \div 4$.

Sur lacceptation de la Conftiturion en forme de Bulle DENOSTRE SAINT PERELE PAPE G'LEMENT XI. 
When the principles of religious reading were established, the clergy could, with good conscience, recommend reading to the believers: "Nous y exhortons les fideles, qui se trouvent dans ces religieuses dispositions, heureux, si nous pouvions augmenter en eux le goût de cette sainte lecture; \& si nous les voyions mettre à profit les grandes veritez, \& les divins precepts, qui y sont renfermez." (Délibérations 1714: 49)

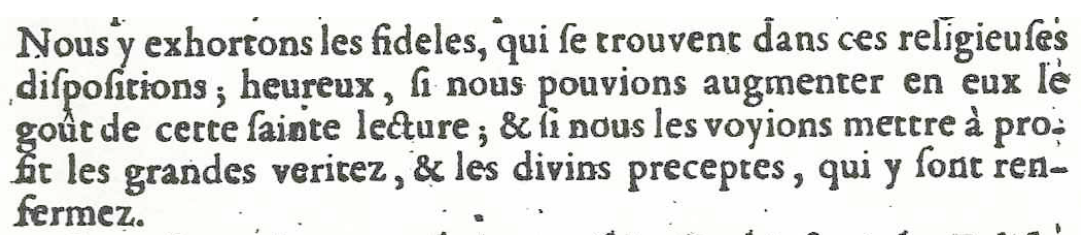

\section{The secular love of reading}

After the vernacular languages were adopted as vehicles of the discourse on reading, it was easy to streamline the phrase le goût de cette sainte lecture into le goût de lecture or le goût de la lecture, or similar phrases in other languages, and transport the discourse on reading and the love of reading into a totally secular domain. This happened more and more starting in the late $17^{\text {th }}$ century in three major European languages - French, English and German. As we have seen (Figure 1), an explosive growth in the use of phrases describing the love of reading in all these languages took place during the late $18^{\text {th }}$ century (Mäkinen 2013a).

One of the prominent figures that may have bolstered the use of the phrases related to the love of reading was Jean-Jacques Rousseau, who praised le gout de lecture of the people of Geneva in his Julie ou la Nouvelle Heloïse (1761). He also developed a pedagogical theory in Émile (1762) that was well suited to the understanding of the individual love of reading (although in the book he did not use the phrase goût de lecture). His greatest influence in this matter appeared in his Confessions (1782-89), where he speaks at length about reading and talks about his tremendous goût de la lecture in his youth. (Mäkinen 2013b, longer version in Finnish: Mäkinen 2013c)

By the end of the $18^{\text {th }}$ century, a consensus seemed to have developed about certain characteristics of the love of reading:

The love of reading

- is an inner drive;

- may be inspired at the right age, in suitable circumstances;

- if not inspired, it may remain latent;

- is difficult to control when unleashed, everyone must find the right balance themselves;

- is part of a complete modern personality;

- reflects the level of education of an individual, group, city, or nation. (Mäkinen 2013a) 
Some aspects of this new kind of extensive reading disturbed people at the time. It seemed to imply a threat of an uncontrollable urge to read that might even threaten the health of the reader, and at least his or her social functions. In some cases, the surge in the habit of reading was so dramatic that it made the establishment nervous. This happened particularly in Germany in the late 18th and early 19th centuries, when a feverish debate sprung up in the press and literature about the potential dangers of reading, as new groups of people, such as women, young people and the lower classes, all seemed to be abruptly starting to read actively and daily. At its worst the phenomenon looked pathological and many alarming words were used to describe it, such as Lesewut (reading rage), Lesesucht (reading lust), and Leserei (reading mania). (Wittmann 1999, Mäkinen 2013a)

\section{The death or survival of the love of reading}

Despite the dramatic debate on the malignant forms of reading, which was especially vehement in Germany, it is clear that, from the viewpoint of the general historical picture, in the long run, a moderate love of reading was accepted as one of the fundamental features of a modern personality.

Still, until the late 20th century, there was a residual suspicion of reading - it contains a threat. People who read can succumb to the allures of an enthralling text and lose their self-determination. Institutions of modern popular enlightenment, such as the public library, were used to direct people to acceptable literature. Only a few decades ago public libraries were careful to select only some books, and not others, because they were seen as harmful for people's intellectual development. Detective stories, romantic novels for women, and the endless series of juvenile fiction and comics were condemned by critics, librarians and people in the establishment.

It is a historical irony that these ideas were totally subverted at the end of the 20th century. Laments about the wrong kinds of reading were quickly replaced by laments about the death of the love of reading. The books that were condemned a few decades earlier would now be welcomed with open arms, if only people would read them.

Today the problem is not the scarcity of books. We live in a reader's paradise. What we are lacking now is the time and intellectual capacity to take advantage of everything that the world has to offer. The response to this challenge is in many ways similar to the situation in the late Middle Ages. We have developed techniques that help us cope with the situation. At the same time we are worried that a part of our cultural traditions may become endangered. Reading a long narrative with a complex story is one of those traditions.

I believe that the comprehension of the historical character of the love of reading can help us view the possible future scenarios more calmly. Something existed before the modern mass reading culture, and something will follow it. 
Many people sense there may be a threat of mediocrity, banality and pure consumerism, if the traditional reading of printed books should disappear. This kind of fear is a recurrent theme in the history of reading and the media in general. However, what history can probably teach us is that total decadence will not result. During the last five hundred years, the number of people who read and the time spent reading, as well as the diversification of the reading material, has continually expanded. However, the average level of sophistication has probably not declined, quite the contrary.

There have always been people who want to read extensive narrative fiction, in whatever form it is available, and they want to read original books in their entirety, just like the monks a thousand years ago. Is it possible that the polarity between these monkish readers and others will be sharper than before? It could happen, but I don't believe it. On the other hand, it seems that popular books are becoming thicker and thicker.

The digital and tablet revolution makes it more convenient than ever before to access reading material, even traditional long narrative texts. There will probably be more readers of narrative fiction than ever before, if the price and the technology are right. The seamless technology itself can create new readers and kindle a new love of reading.

It is also generally believed that people's ability to concentrate has diminished. Many of my students share this belief and say that they have observed it in themselves. I don't doubt their observations, although I suspect that they have been influenced by the current alarmed discussion, especially in Nicholas Carr's book Shallows, which many of them have read. People read texts in small bits and then move on to another website, Facebook update or tweet. Is there any coherence in what people are reading and doing? The lack of concentration, as well as the deterioration of memory that many also lament, is probably an illusion. Our world is extremely complex and various media demand our attention: it seems that we are doing quite well, and when the need arises, we can concentrate if the matter requiring attention is important to us.

Do we need the ability to read extensive fiction? Many believe that people cannot learn to read properly if they do not read long fiction at some point in their lives, and that there is a danger that technically bad readers will not develop total reading ability and be cast aside in society.

This concern is at the root of the revival of the discussion on the love of reading. This is exemplified by the Finnish Lukuinto - läslust Project, the name of which contains the term "love of reading" in both Finnish and Swedish. The goal of the project is to "strengthen the interest and ability of children and juveniles related to versatile reading and writing" (http://www.lukuinto.fi/). Another example is the European project ADORE - Teaching Struggling Adolescents Readers in European Countries. The goal of ADORE is to find ways to support the reading motivation of weak and struggling readers. It is essential to understand that reading is not self-sustaining if a person does not have a personal 
desire to read or an inner love of reading. In the background, there are theories of "engaging reading" - another expression for the love of reading. Reading is not only a cognitive operation, but is also affective to a great degree (Garbe \& Holle \& Weinhold 2010, Guthrie \& Wigfield 2000, Guthrie \& Davis 2003, Linnakylä \& Arffman 2007, and Puksand 2012).

There are other researchers who are more up-to-date on the current trends in reading. In general, I believe that there is no need to expect that all of today's trends will continue and develop into dominant ones. New trends and memes can appear at any time. Everything is in flux, nothing is certain, but this also means that the future is also not cast in stone.

The modern love of reading is a product of the print culture. What was the situation before the mass production of texts, even before (or simultaneously with) writing? Can there be intelligent life without extensive reading? Can we expect anything better than a return to the Athens of Ancient Greece (if we disregard the slavery, the suppression of women and many other ugly features)? In Athens the production of literature was at a high level, but what about the consumption? In fact, the Athenian plays, poems and philosophy were more oral and virtual than textual. The Athens of Pericles was a buzzing beehive of social media and public discussion. Is that where we are heading?

\section{References}

Darnton, R. (1988). Readers respond to Rousseau. In R. Darnton. The great cat massacre and other episodes in French cultural history. London: Allen Lane.

Engelsing, R. (1961/1973). Der Bürger als Leser. Die Bildung der protestantischen Bevölkerung Deutschlands im 17. und 18. Jahrhundert am Beispiel Bremens. Archiv für Geschichte des Buchwesens III, 1961. Republished in a revised form in R. Engelsing. Der Bürger als Leser. Lesergeschichte in Deutschland 1500-1800. Stuttgart: J.B. Metzler, 1973.

Engelsing, R. (1970/1973). Die Perioden der Lesergeschichte in der Neuzeit. - Archiv für Geschichte des Buchwesens X, 1970. Republished in a revised form in R. Engelsing. Zur Sozialgeschichte deutscher Mittel- und Unterschichten. Göttingen: Vandenhoeck und Ruprecht, 1973.

Friedenthal, M. (2013). Kääbustest ja hiiglastest. Keel ja Kirjandus, 7, 481-489.

Garbe, C., Holle, K. \& Weinhold, S. (Eds.) (2010). ADORE - Teaching Struggling Adolescents Readers in European Countries. Key elements of good practice. Frankfurt am Main, etc: Peter Lang.

Gilmont, J.-F. (1999). Protestant reformations and reading. In G. Cavallo \& R. Chartier (Eds.), A history of reading in the West. Cambridge: Polity Press.

Guthrie, J.T. \& Wigfield, A. (2000). Engagement and motivation in reading. In M. Kamil et al. (Eds.), Handbook of Reading Research. Vol. III. Mahwah, N.J.: Lawrence Erlbaum. 
Guthrie, J.T. \& Davis, M.H. (2003). Motivating struggling readers in middle school through an engagement model of classroom practice. Reading and Writing Quarterly, 19, 59-85.

Hamesse, J. (1999). The scholastic model of reading. In G. Cavallo \& R. Chartier (Eds.), A history of reading in the West. Cambridge: Polity Press.

Julia, D. (1999). Reading and the counter-reformation. In G. Cavallo \& R. Chartier (Eds.), A history of reading in the West. Cambridge: Polity Press.

Leclercq, J. (1993). The love of learning and the desire for God. A study of monastic culture. New York: Fordham University Press.

Linnakylä, P. \& Arffman, I. (Eds.) (2007). Finnish reading literacy. Jyväskylä: University of Jyväskylä.

Mäkinen, I. (1997). "Nödvändighet af LainaKirjasto": Modernin lukuhalun tulo Suomeen ja lukemisen instituutiot. Helsinki: Suomen Kirjallisuuden Seura.

Mäkinen, I. (2013a). Leselust, Goût de la Lecture, Love of Reading: Patterns in the discourse on reading in Europe from the 17th until the 19th century. In A. Navickiene, I. Mäkinen, M. Torstensson, M. Dyrbye \& Tiiu Reimo (Eds.), Good Book, Good Library, Good Reading. Studies in the History of the Book, Libraries and Reading from the Network HIBOLIRE and Its Friends. Tampere: Tampere University Press.

Mäkinen, I. (2013b). Why people read: Jean-Jacques Rousseau on the love of reading. In D. Gustafsson \& K. Linnovaara (Eds.), Essays on Libraries, Cultural Heritage and Freedom of Information. Festschrift published on the occasion of Kai Ekholm's $60^{\text {th }}$ birthday on 15 October 2013. Helsinki: The National Library of Finland.

Mäkinen, I. (2013c). Lukuhalun vallankumous ja Jean-Jacques Rousseau. Kasvatus \& aika, 1. Available: http://www.kasvatus-ja-aika.fi/site/?lan=1\&page_id=529

Negrone, G. (1621). De lectione privata librorum spiritualium. Tractatus asceticus $V$. Venetia.

Northern Light on PISA 2009 - focus on reading. Available: www.norden.org/en/ publications/publikationer/2012-501

Puksand, H. (2012). Eesti kooliõpilaste lugemisharjumused. Keel ja Kirjandus, 11, $824-835$.

Wittmann, R. (1999). Was there a Reading Revolution at the end of the eighteenth century? In G. Cavallo \& R. Chartier (Eds.), A history of reading in the West. Cambridge: Polity Press. 


\title{
The logic of text and structure of books: Changing the functions
}

\author{
Kurmo Konsa, Edith Hermann
}

Books are paradoxical objects. Based on their external shape, they are material objects, but their content is comprised of texts, the immaterial creations of authors, which can exist in various physical forms. The development of digital technology has decreased the relations between text and its physical shape, i.e. books as objects. Today, the process of publishing books is digitalised to such a degree that the only non-digital object is the final product of the process - the book itself (Kovač 2008). Both the text contained in the book and the physical form of the book represent a certain culture and record different types of information. In recent decades, in connection with the topical issue of preserving cultural heritage, the interest in the material presentation of texts has been constantly increasing, as each text needs an output via some type of artefact; it may be a bound book, a manuscript, a document or an image on the computer screen.

In this article we concentrate on the analysis of the informational structure of books as informational artefacts. The interest in books as artefacts is nothing new. Books as objects were scientifically studied already in the eighteenth century. With the spread of digital media, the interest in books as objects has increased. Whereas at first, this was primarily related to a fear that book culture might disappear; later the interest has focused on highlighting the corresponding characteristics of print and digital media, and comparing the two. In the first part of the article we describe the separation of digital text from books as artefacts and present the features of digital texts that have made this possible. In the second part of the article we introduce the informational model of the book, and based thereon, show the alternation of book functions in the context of wider spread and usage of digital texts. 


\section{The logics of digital texts}

The contemporary world is mostly made up of texts. In addition to texts in books, it also includes electronic mail, Wikis, blogs, posts in social networks, instant messaging, etc. In a narrower sense, text can be defined as information presented in writing. Based on a wider definition, texts can also be seen as several ways of presenting information. Information is always presented in material form: the movement of electrons in a wire or a radio wave in the air; colour molecules on a solid surface; the movement of electrons and ions in living matter; air vibration, etc. However, these material forms do not mean that information is constant in time. In order to continue using information after it is created, it must be saved or recorded in a more permanent form. Therefore, an information object (also, a communicative artefact) is a material object that carries information.

On the level of an abstract information object, there is no difference between information presented in analogue or digital form. Instead, the content, the fixed structure, and the existence of context are important - they allow the information to be decoded and understood. However, an examination of the presentation of signals reveals quite remarkable differences between the analogue and digital presentation of information. The information presented in analogue form is more closely related to the medium. The content and structure of a text on a printed page are preserved as long as the paper exists. In the case of digital information objects, the connection between the medium and the information is much more ephemeral. In order to explain this, digital information objects are classified into three different classes: objects, logical objects and conceptual objects (Thibodeau 2002).

Physical objects are signs inscribed on a medium or signals conveyed in some other way. The process of inscribing these signs on a medium depends on the medium. The signs are read with the help of computer hardware and software, and transformed into logical objects. The logical form of an object can be recognised and processed by application software. The logical form of an object does not depend on the way information is written on the physical medium; in other words, it is independent of the physical object level. The rules applied at the logical level determine how information is encoded in bits and how the different encodings are processed thereafter. When people are presented with a logical object, they perceive it as a conceptual object. People can understand and process conceptual objects. There can be very different recognisable conceptual objects, such as documents, photos, e-books, mathematical formulas, films, etc. The content and structure of a conceptual object are contained in one or several logical objects. However, the structure of a conceptual object can greatly differ from that of a logical object. For instance, the content of a document can be digitally encoded as an image of a page (picture file) or a 
text document (Word.doc file). These are different logical presentations of the same conceptual object.

Digitally presented information is dependent on an entire chain of encoding and decoding stages, and the information presented to the reader is created at the moment of its reproduction. In order to use a document that is preserved in its physical form as a bit sequence, it has to be interpreted as a logical object and then presented as a conceptual object. Digital preservation does not merely concern the preservation of physical objects, but also concerns the ability to reproduce these objects.

How does this affect text? Digital texts are also related to physical data carriers such as DVDs, hard disks, flash drives, computer screens, etc. However, the relationship between the text and the physical carrier is less important than in the case of traditional documents, books or photos. Some digital data carriers can be culturally significant, but they are by no means relevant textually. In comparison to previous information carriers, digital text is much more variable and changeable. On the other hand, these features make the text easier to edit and distribute (Tredinnick 2008: 68-71). However, in relation to the emergence of digital text, the question has been raised concerning the stability of the text. Text has become changeable, freed from the grasp of publishers and printing houses. Writing and printing on paper fixed what had been written, and gave an impression of stable and permanent information. Digital information is fully integrated into the communication processes and acquires its meaning in the constant activity of these processes. In this sense, it is somewhat similar to oral speech. The definitions of authoritativeness and originality of information have changed. Anyone can create information, and the mechanisms of authenticity and authoritativeness no longer function. It might seem that this development could threaten the value of knowledge; actually it is mostly related to the system of creating, distributing, using and reusing knowledge, and less to its essence and value. The system of centrally creating knowledge and fixing its authority is slowly being replaced by a network of social relationships, their participation rate, and status. Owing to the nature of digital objects (chains of encoding processes) and the fact that they are easily changeable, they are now related to the context of use, not to their creation. The value and meaning of digital objects is formed in the course of using them, not when creating them.

To sum up, it can be stated that the amount of textual information is increasing at a fast pace and different types of texts are emerging. Stable textual information in the shape of books will definitely continue to exist, if only in digital form. It is indispensible for texts that present longer narratives or logically structured discussions. The exact physical form of presenting such texts (book, e-book etc.) will be dependent upon their specific context and function. 


\section{Informational structure of books}

Books are communicative artefacts, which are used mainly to present information in textual form. Artefacts are all manmade material objects - from geological samples that have been collected (i.e., removed from their original context) and preserved for a certain purpose, to the most complicated technological objects. Communicative artefacts make up a separate group of artefacts. They include, for example, books, documents, pictures, sound recordings, computer data carriers, etc., and their main function is to preserve and mediate information (Levy Marshall 1995: 78). Books are definitely among the most widespread artefacts; and large numbers of them have been preserved from previous centuries. Along with buildings and coins, books are among the most numerous items that have survived from the Middle Ages (Hamel 2008: 3).

Every artefact is essentially an inexhaustible source of information. Various authors have proposed different approaches to describing artefact-related information (Pearce 1986; Fleming 1982). In the case of communicative artefacts, two main ways of describing their information structure can be identified. Probably, the most widespread and understandable is the model where the information contained in a book is dichotomised; in other words, a book is treated as being made up of its content in the widest sense of the word, and as the material carrier of its content. A book is a like a container consisting of text that can be transferred from one container to another without any information being lost. As Linnar Priimägi puts it in his essay "The Unbearable Lightness of the Renaissance Spirit":

Literature does not require books, a book is merely a temporary rental apartment for literature, a pile of paper bound on one edge - a ridiculous item, although one of the most ingenious inventions for its convenience (Priimägi 2000).

The dichotomous model results in the abstraction of text or content from the artefact, and in many cases this leads to claims that the text is the actual object being preserved. The dichotomous model often provides the grounds, either formally or informally, for many preservation-related activities. Microfilming, digitalisation, and other ways of reformatting information are actually based on this theoretical model. When treating a book based on the dichotomous model, one could claim that the digital age has brought about the death of books. If books are viewed merely as texts or containers for texts, it can be said that the era of books is ending. Texts left books a long time ago and exist in different physical shapes. However, books are not merely related to text. First and foremost, they are physical objects, which, in most cases, also include text. Nevertheless, when looking at some art projects that are realised as books, for example, the presence of text is not indispensible to the object being seen as a book. 
Another possibility is to try and describe all the possible information levels related to the different artefacts. In this case books are treated as multilevel information objects, which along with the text, contain various other types of information. Books are a part of the culture of their time and bear the social contexts that have created it. This study is based on a three-level model, according to which three different information levels are distinguished:

- structural information or structural properties;

- functional information or functional properties;

- the context and the relationship of an object to its context.

\section{Structural information}

Structural information encompasses all the physical (structural) features of an object, such as material, construction, design, etc.; i.e., the entire information that can be perceived by the senses and studied with physical and chemical research methods. The term "object" or "artefact" is usually used in this sense to designate an object in its physical sense. The source of structural information is the artefact itself, whereas with the following information levels, information must be obtained from additional sources.

A book is comprised of various types of materials, such as paper, printing ink, cardboard, leather, etc. Each material has a complicated composition and different physical and chemical properties (Federici 1985). The damaging processes of artefacts are largely dependent upon the properties of materials. The main material used for printed works is paper. The composition of paper has changed considerably throughout the history of its production and these changes have also significantly affected the ageing and preservation of paper. All the other types of materials used to prepare books are also affected by ageing (Konsa 2008: 46-53). The construction of an object indicates the way the object is made and the components it is comprised of. Changes have occurred in the construction of books as new materials and technologies have come into use, but also as tastes and user requirements have changed. Design describes the appearance of an object, its shape, colour, ornamentation, iconography, etc. Objects of the same material and construction can have different designs.

The format of communicative artefacts is especially important, as it reflects the way information is presented, structured, and laid out. The following format elements can be identified:

1) the means of expressing information (content): content can be expressed as text (i.e., a sequence of words), as a picture or a combination of the two, as data, cartographic material, notations, etc.;

2) the means of presenting information: how the text is laid out, structured, designed, etc.;

3) additions: all kinds of additions made later, such as annotations, underlining, notes, bookplates, etc. 
Indirect or unintentional information is information that is unintentionally included in the object or has been collected in the object during its "lifespan". The amount of such information is quite large, as documents and books are relatively good information collectors. Paper as a material has excellent absorbent properties; it binds well with gases and liquids as well as solid particles. Bindings have many folds and other hidden parts where objects can end up, either intentionally or not, and be preserved intact for a long time period. With the help of modern physical and chemical analysis models, this kind of information can be used for drawing fascinating conclusions (Vnouček 1991). For many artefacts, sound, smell, and taste can also be important structural features. In the case of books, for instance, we can discuss the sound of turning the pages, the smell of the printing ink in new books, etc. (Frost 2005; The Smell 2009).

\section{Functional information}

Functional information refers to the use of artefacts. An artefact can naturally perform different functions. In the case of objects that are carrying information, the most important function is usually the communicative one. Such objects are created in order to mediate certain ideas, knowledge, etc. We read a book primarily for its content, and therefore, the text of a book can be categorised under functional information. A text that has been functionally interpreted by a person can be called a teos in Estonian ("work of activity") as Virve Sarapik did (1999: 9-10), or just the content of a book. Functional information is carried by the book as an object. Often this means an aesthetic function. Books are considered to be works of art; e.g., they can be used to decorate interiors. ${ }^{1}$ The semiotic study of items emphasises the meanings that indicate something outside the object, either something that has happened, an abstract idea, meaning, etc. Objects mean something; they function as a certain sign and/or text. Such functions of artefacts can be called symbolic. Books have a remarkably strong symbolic function, because of their content and their existence as physical objects (Debray 1996: 141, 143-145). The ownership of certain books demonstrates education, wealth, high social status and prestige. Therefore, these objects also perform a value function, providing information about the wealth, social status, self-perception and interests of the owner or the user. Metaphysical function refers to the relationship with the supernatural world which is attached to various artefacts, including books. In several religions - for instance, Christianity and Islam - a book is the symbol of divine revelation. In Islamic mysticism, a book is the metaphor for the entire universe. ${ }^{2}$

See for example Lotman 1990.

2 See for example Cirlot 1990: 31. About books as magical objects, see Kieckhefer 1997: 4-5. 
The functional information of artefacts is actually very complicated, comprising a complex ever-changing structure. Books perform different functions one for its author, another for the publishing house, the printer, in someone's home on the reading desk, at the library, or at an exhibition of rare books. To a great extent, the functions of an artefact are related to its context, which is the third component of the informational structure of an object.

\section{Context}

The word "context" originates from the Latin word contextus, which means a connection or a link. In this model, it signifies the relationship between the artefact and the environment. Context can be described as a two-dimensional system: material (physical) and conceptual. The physical context includes all the other objects that the book is related to during its preparation and further use. ${ }^{3}$ It is very important to take the physical context into account in case of collections. Identical artefacts can carry different meanings in different collections; also the value of the object can also depend on its belonging to a certain collection.

Context as a conceptual system can be understood as the cultural and social environment related to an artefact. There are many types of social and cultural data linked to the role of the object, its meaning, and significance. For books, important contextual aspects can include the economy, trade, and informational organisation of the society, the description systems for books, production, tools, technology, work division, worldview, and art, to mention a few. Context can be related to the history of the object. Often it is not the object itself that matters the most, but the persons to whom it belonged or the historic events to which the object was connected. The values attached to the object are also a part of its conceptual context. In the treatment of informational structure of artefacts, their values are the features attributed to them; the idea- and emotion-related connections that lend importance to the objects and determine their significance for a person, community or society. The concept of value has a positive connotation here; if an object has value, it means that it is appreciated and used in the society for a certain purpose. One object can usually have several types of values. The values attributed to books are the foundation of their usage in the society.

As functional and contextual information is information about the artefact, it is not stored by or contained in the artefact itself. The objects of written heritage - books, manuscripts, magazines, newspapers, documents, microforms, digital objects, etc. - can be studied as physical objects to obtain two major types of information, which can affect the interpretation of any texts that are presented on them. One kind of information relates to the contextual information of the communicational artefacts -their materials and production

3 A very interesting treatment of the mutual development of books and way they are shelved can be found in Petroski 1999. 
techniques, i.e., how objects were made. The process of production involves very different phenomena - technical knowledge, manual skills, and materials with specific properties. Some of these properties can be comprehended intellectually and others can only be understood or checked manually. The other kind of information focuses on the effects of the structural properties (material, design, etc.) on readers' responses. Such research is clearly relevant to the history of reading and the transmission of ideas.

\section{Dynamics of the information structure of artefacts}

The described model provides the static representation of the informational structure of artefacts. However, in order to develop adequate approaches to preservation practices, it is necessary to reconstruct an artefact's biography. The informational content of the artefact results from a historical process. The historical process includes where, when and how the artefact was made; by whom, for whom and why it was made; and the successive changes in its ownership. In the biography of artefacts, three stages can be distinguished: the conceptual stage, the factual stage, and the actual stage. The first stage is the idea of the maker. This idea is related to the conceptual context of the maker. This is, in fact, the potential object. The other stages refer to the actual object. The factual stage refers to the object as it was intended by the maker, just after the completion of the production process. During an artefact's lifespan, its information content changes. The result of these changes in information at all levels (i.e., structural, functional, and contextual levels) constitutes the actual identity of the artefact. This is the artefact as it appears to us now. Structural properties, functional properties, and the context of artefacts change in time. An artefact has a physical existence, and consequently it provides information on its own genesis. Changes, alterations, and traces of wear also tell us something about the "life" of the artefact. Deterioration is usually understood as the loss of information. Paradoxically, many types of damage can add to the documentary value of an artefact as traces of its biography. Deterioration can also contribute to the aesthetic value of an object.

Changes in the informational content of artefacts are affected most by different human activities. Using artefacts changes them. Objects wear in the course of being used, they are damaged in various ways, and objects may partly or totally deteriorate. Changes in social ideology often bring about the destruction and change of artefacts. For example, there have been countless occasions in history when books have been destroyed, starting with the destruction of the 
famous Library of Alexandria in $47 \mathrm{BC}$, and ending with the burning and looting of the Iraq National Library and Archives in 2003. ${ }^{4}$

The functions of an object also change, as do its structural features. As a general rule, the utilitarian value of an object decreases in relation to its physical, technological and psychological ageing. When an object loses its practical value, it is often discarded or reused as raw material. A much more interesting situation occurs when the practical value of an object decreases, but its aesthetic and symbolic value increases. For example, a utility object can become seen as a work of art thereby changing both its meaning and function. Books that we can no longer read often become visual works of art. The transformation of an object's functions can also bring about changes in its structural features. As the values attributed to books change, so do the functions they perform. The main function of books to date - being intermediaries of textual information - is starting to diminish and transform in relation to the spread of digital information. Books will undoubtedly remain the main representatives of certain types of texts and treatments of text; however, they will cease to be the main "machines" of textual information. In the course of this shift, the other values that books have and the functions based on these values are prioritised.

The informational structure of an artefact is not simple, because different information levels are interconnected and influence each other. From the perspective of the informational structure of the artefact, preservation is not a passive action. Preservation technologies are not perfect. Some information is lost in order to save other information, and difficult decisions have to be made in order to save what, at the time, is considered to be information that will most likely be of enduring value. Copies are always interpretations. These interpretations are biased according to our own understandings and culture. During the reformatting processes, new objects are created with their own informational structure. When information is transferred to other media some information is inevitably lost. When an artefact arrives at a memory institution - library, archive, or museum - its functional and contextual information has already changed; not to mention the conservation or reformatting of the information, which also changes the structural, functional, and contextual information. Upon selecting preservation strategies, it is essential to consider the information structure of the artefact, especially if information reformatting technologies are used, which create a new object with a specific information structure (e.g., making photocopies, creating microforms, digitalisation, etc.). The preservation of books, like the preservation of other artefacts, presumes that the set of information to be preserved has been identified in advance.

$4 \quad$ About the destruction of books, see Polastron 2007, Lowenthal 1998, Sarefield 2004. 


\section{Summary}

Manuscripts and printed books are artefacts, and as such, they contain various kinds of information. This information is not only related to the textual content, but also to the history of their production. Thereby, we can also learn about the history of a particular society. Manuscripts and printed books are a part of the material culture of their eras and carry the corresponding social context. Such information is important from the point of view of book history, and it also affects the meaning of texts. The reception of a text is largely dependent upon its presentation. A book, as any other informational artefact, is always read as a whole. All the elements - the paper, dimensions and shape of the pages, text layout, font, binding material and design -have meaning for the reader, as all these details play a part in the reading process. The informational structure of an artefact is not simple, as different information levels are interrelated and affect each other. To use a term coined by Juri Lotman, we can observe each artefact as a unique semiosphere, in which the informational structure of an object comprises an organised core and diffused periphery. Digital technology has already significantly changed the ways in which we create, spread, use and understand information, including the information that has traditionally been contained in books. In the course of these changes, the values related to the creation, usage, and preservation of information also change. To treat a book as a mere container of information would indeed mean acknowledging its death. Texts can be presented by using different methods; the book as an object, however, is unique.

\section{References}

Cirlot, J. (1990). A Dictionary of Symbols. Routledge.

Debray, R. (1996). The Book As Symbolic Object. In G. Nunberg (Ed.), The Future of the Book. Berkeley, CA: University of California Press.

Federici, C. (1985). Methodology and practice of archaeological analysis in the study of book materials. PACT: Journal of the European Study Group on Physical, Chemical, Biological and Mathematical Techniques Applied to Archaeology, 12(12), 261-274.

Fleming, E. (1982). Artifact study: a proposed model. In T.J. Schlereth (Ed.), Material Culture Studies in America, Lanham: Altamira Press.

Frost, G. (2005). Reading by Hand: The haptic evaluation of artists` books. The Bonefolder: an e-journal of the bookbinder and book artists, 2(1), 3-6.

Hamel, C. (2008). Books and society. In N. Morgan \& R.M. Thomson. (Eds.), The Cambridge History of the Book in Britain, Volume II, 1100-1400. Cambridge: Cambridge University Press.

Kieckhefer, R. (1997). Forbidden Rites. Stroud: Sutton Publishing.

Konsa, K. (2008). Arhivaalide ja trükiste säilitamine. Tartu: Kleio.

Kovač, M. (2008). Never Mind the Web: Here Comes the Book. Oxford: Chandos. 
Levy, D. \& Marshall, C. (1995). Going Digital: A Look at Assumptions Underlying Digital Libraries. Communications of the ACM, 38 (4), 77-84.

Lotman, J. (1990). Kunstikooslus kui olmeruum. In J.Lotman. Kultuurisemiootika. Tekst-kirjandus-kultuur. Tallinn: Olion.

Lowenthal, L. (1998). Caliban`s legacy. Publishing Research Quarterly, 4(3), 74-83.

Pearce, S. (1986). Thinking about Things. Museums Journal, 85(4), 198-201.

Petroski, H. (1999). The Book on the Bookshelf. New York: Vintage Books.

Polastron, L. (2007). Books on Fire. London: Thames and Hudson.

Priimägi, L. (2000). Renessansivaimu talumatu kergus. Arkaadia. Eesti Päevalehe kirjanduse ja esseistikalisa, 16. september.

Sarapik, V. (1999). Keel ja kunst. Tallinn: Underi ja Tuglase Kirjanduskeskus.

Sarefield, D. (2004). Burning knowledge: Studies of bookburning in ancient Rome. Dissertation. The Ohio State University. http://www.ohiolink.edu/etd/send-pdf. cgi?osu1092663236 (26. XI 2009).

The Smell of a Book. http://www.topics-mag.com/edition19/smells/book.htm. (26. XI 2009).

Thibodeau, K. (2002). Overview of technological approaches to digital preservation and challenges in coming years. In The State of Digital Preservation: An International Perspective. Conference Proceedings. Washington, D.C.: Council on Library and Information resources.

Tredinnick, L. (2008). Digital Information Culture: The individual and society in the digital age. Oxford: Chandos Publishing.

Vnouček, J. (1991). Can we manage to restore medieval books without any loss of information? In Internationale Arbeitsgemeinschaft der Archiv-, Bibliotheks, und Graphikrestauratoren. Preprints. Uppsala. 


\title{
II. BOOKS AND READERS
}

\section{Changes in the character of book consumption in Estonia, 1979-2011}

\author{
Peeter Vihalemm
}

\section{Introduction}

Book consumption has declined during last two to three decades in very many Western countries, especially among the younger generation. The rapid and large-scale expansion of digital media has radically changed reading habits and caused pessimism about the future of the printed word.

These trends also characterize Estonia. In the 1970s and 1980s interest in books was significantly higher in Estonia than in the Western countries. Almost two-thirds of Estonians bought books at least once a month. The average print runs of books in Estonia reached 8,000-9,000, and were higher than in Nordic countries despite their larger populations (Lauristin \& Vihalemm 1986: 485). Since the early 1990s book demand in Estonia has decreased dramatically; the average print run in 2012 was 1,200 copies. The share of regular fiction readers has declined two to three times.

How can we explain these changes? Are they caused mainly by global trends in book consumption or by the societal transformation to a market economy and democracy?

This article examines how the level and character of book consumption has changed in Estonia over the last 30 years from the late 1970s to the early 2010s, using the results of the representative sociological surveys conducted by the Institute of Journalism and Communication at the University of Tartu (formerly the Department of Journalism).

\section{International trends in book demand}

In the late 1960s the emerging consumer society brought about significant changes in book demand in many European countries - the publication of 
serious fiction and classics started to decrease, the publication of popular literature (romances, crime stories, westerns) and non-fiction to increase. Since 1970s in the Nordic countries, book demand has been sharply divided into two parts: universal demand for practical and entertaining books and specialised demand for high-quality literature, including most new fiction (Gedin 1982).

The status of spiritual values has fallen so low that they are not considered no longer worthwhile pursuing other than those with a definite special interest. Schools and universities see as their main task the creation of educated citizens as quickly and efficiently as possible; citizens who can rapidly be utilized in the production of further material goods.

It is perfectly natural that culture cannot be given much space in such a social pattern. Therefore, it will become more and more the concern of specialists, if, of course, it is not a part of mass culture. (Ibidem: 165)

Due to the change in cultural standards and rising prices, the average print runs for original novels or more serious translated fiction decreased in Sweden to less than 3,000 (and despite the small editions, half of these books sold less than 1,000 copies). On the other hand, entertaining bestsellers were printed in editions of more than 25,000 copies (ibidem: 106). The same contradictions between quality books and bestsellers also emerged in other West European countries and U.S. (ibidem: 226-238).

Since the 1990s the analyses of book reading have been less focused on the contradictions between elite and mass literature, and more on the decline of interest in books, especially among the younger generation in connection with the rapid growth of digital media usage.

Interest in books is decreasing in many countries - in the U.S. (Bradshaw, Nichols \& Bauerlein 2004; Rainie et al 2012; NEA 2013), the Netherlands (Knulst \& Kraaykamp 1997), probably even more so in the post-Communist countries, in Russia (Rubinova 2010; Kononova 2011) and Poland (Gotowska 2011).

On the other hand, in some countries interest in books has been stable or has even increased. Between 1995 and 2008, the number of books sold in Finland has increased, in 1995 69\% of population bought at least one book while $77 \%$ did in 2008 (Suomi lukee 2009). The number of non-fiction books sold has decreased due to the influence of the Internet, but the buying and reading of fiction has remained stable (Herkman \& Vainikka 2012: 15). The share of book readers (percentage of persons who has read at least one book a year) has decreased from $82 \%$ in early 1990 s to $75 \%$ in 2002 , but remained stable thereafter (Tilastokeskus 2009).

In Sweden the share of regular book readers (persons who have read books at least once a week) has increased from $29-32 \%$ in $1979-1993$ to $36-38 \%$ in 1997-2011 (Nordicom 2012). At the same time, the share of men who never 
read books has increased - in 1982 their share was 22\%, in 2005, 31\%. Among women, the share of non-readers has been stable at about 15\% (Statistics Sweden 2007). The same trend of men reading less than women also characterises Finland and many other countries, including Estonia.

Until the beginning of 1990 s the book reading situation in Estonia was quite different from the Western world; thereafter, the trends in book demand have been similar. What features in this area were specific to Estonia and why did they disappear after the restoration of independence?

\section{The role of books during the decades of Soviet occupation}

A couple of decades ago, Estonia was among the most book-loving nations in the world, in respect to books that were published and read, especially to books that were bought. From the late 1950s until the early 1990s Estonians were very cultural engaged and this was characterised by the great popularity of Estonianlanguage books. The average print runs of domestic novels in 1980s ranged from 30,000 to 40,000 , of poetry from 5,000 to 7,000 (for a population of less than 1 million). The maximum print runs of fiction were 60,000 , which were very rarely exceeded even if demand was greater (Kaints 1999: 1544). In cases of extreme demand, the print runs of non-fiction could be higher, for instance, between 1985 and 1990, the print run of the national encyclopaedia totalled 220,000 due to the pre-bookings. After 1992 it was smaller, but thanks to several additional printings, still reached 60,000 (ibidem: 1547).

A survey conducted by sociologists at the Institute of History showed that the share of the working population that reads fiction at least once a month increased from $55 \%$ in 1966 to $92 \%$ in 1978 , and the share of readers of nonfiction from $23 \%$ to $74 \%$ respectively (Perekond ja kultuur 1985: 40). In 1978, $60 \%$ of the working population attended the theatre at least once a month (Arutjunjan \& Kahk 1980: 51).

Culture and education was held in high regard in almost all parts of the Soviet empire; the authorities emphasised active cultural participation as an indicator of a flourishing Communist system. Culture was subsidised by the state, and the prices of books, theatre and concert tickets were low. In Estonia and the other Baltic countries the prestige of cultural activities was especially high, however, there were also other reasons for this.

Cultural activities partly compensated for the lack of opportunities in the political and economic spheres, and functioned largely as cultural resistance to the totalitarian political regime and ideology (see Hoyer, Lauk \& Vihalemm 1993). We can say that cultural participation was the main carrier of national identity. 
[In the 1960s] culture, nature protection and sports became the areas where natural processes could evolve more normally, i.e., where the grass was allowed to grow unhampered. Compared to Russia, the development of fine arts and literature in the Baltics was not as directly controlled by the Communist Party. (Hoyer, Lauk \& Vihalemm 1993: 30)

Media in the national languages also partly fulfilled the functions of cultural opposition and national integration. On the one hand, media was an important part of the ideological state apparatus. On the other hand, it was a part of the national cultural sphere and the carrier of cultural opposition. Already due to the linguistic differences, it was not possible to for the authorities to completely understand and control the media.

The ethnic culture of the Baltic people, which was largely disseminated and developed by mass media, served as a special sanctuary, a different world, which, although influenced by Soviet ideological standards, preserved a mechanism of self-regulation and natural evolution. (Ibidem: 214)

Book buying intensified at the end of the 1950s together with the relative social liberalisation and improvement in living standards, and was quite active until the early 1990 s. According to representative surveys organised by the sociologists from the Institute of History and the National Library, 37\% of working-age Estonians had no books at home in 1966, and in 1977, the respective number had diminished to 5\% (Järve 1985: 15). The number of published titles per capita in the mother tongue was higher in Estonia than in the other Soviet Republics; and the level of expenditures for books and printed media was even higher. In 1984, every inhabitant of the USSR spent an average of 15.50 roubles for books and printed media, and every inhabitant of Estonia spent 26.30 roubles (for comparison - only 3.60 roubles more were spent on bread) (Lauristin \& Vihalemm 1986: 385).

The great interest in books and the theatre, as well as the large press readership was spread relatively evenly among all social groups; the educational differences and differences between urban and rural population were much smaller than in the Western countries. According to our surveys, at the beginning of 1980 s, $42 \%$ of households in the Estonian countryside also had home libraries, which consisted of at least several hundred books, while $10 \%$ of households had libraries with over thousand books.

In the 1960s, 1970s and 1980s, there was an unsatisfied demand for books a deficit of books in Estonian. Quite often new books sold out very quickly. The active book buying by Estonians raised questions about their motives. "Why do people rush to bookstores to queue up early morning in order to make pre-bookings for books? To what degree are serious cultural interests at play and how much is affectation and the desire for appreciation?" (Lauristin \& 
Vihalemm 1985: 247). The answers to these questions provided by our studies emphasised that both are important - a high level of cultural interests, as well as, prestigious consumption, i.e. books at home were an important indicators of people's lifestyles and everyday environments.

At the early 1980s local Russians ${ }^{1}$ were just as avid readers of books as ethnic Estonians. However, a big difference existed between these ethnic groups in book buying habits and the size of their home libraries. Almost two-thirds of Estonians bought books at least once a month; while only slightly over a quarter of the Russophones did so. Ninety-four percent of Estonians and 74\% of Russophones had a few dozen books had at home, and about a half of the Estonians and a quarter of the Russophones had considerable libraries at home (at least several hundred books) - Table 1.

Table 1. Contacts with books of Estonians and Russophones at the beginning of the 1980 s ( $\%$ of the population over 18 )

\begin{tabular}{r|c|c}
\hline & $\begin{array}{c}\text { Estonians in } \\
\mathbf{1 9 7 9 - 1 9 8 4}\end{array}$ & $\begin{array}{c}\text { Russophones in } \\
\mathbf{1 9 8 1}\end{array}$ \\
\hline Reads fiction: & & 64 \\
\hline at least once a week & 57 & 24 \\
\hline several times a year, less often & 25 & 12 \\
\hline Loves to read poetry & 35 & 52 \\
\hline Often reads professional literature & 24 & 21 \\
\hline $\begin{array}{r}\text { Often reads popular non-fiction } \\
\text { (popular science, memoirs, travel books) }\end{array}$ & 19 & 11 \\
\hline Books at home: $\quad$ & & 26 \\
\hline about one hundred or two hundred & 26 & 24 \\
\hline several hundred & 35 & 21 \\
\hline about a thousand, or a few thousand & 16 & 4 \\
\hline Books are usually bought: & 6 & 27 \\
\hline at least once a month & 62 & 49 \\
\hline several times a year & 29 & 24 \\
\hline once a year or less & 9 & 27 \\
\hline
\end{tabular}

Source: Sociological surveys of the Department of Journalism at the University of Tartu ${ }^{2}$

1 Actually Russophones, this population group also includes Ukrainians, Belarussians and many other nations of the former Soviet Union.

2 In 1979-1984 the total representative sample of Estonians in age over 18 included in four rounds of survey 3791 respondents. In 1981 the representative sample of Russophone population in age over 18 included 679 respondents. 
The "Singing Revolution" in 1988-1990 was also a period for restoring the national memory. For the first time in Estonia's post-war history, the historical truths about the War of Independence between 1918 and 1920, the Soviet occupation and annexation of Estonia, World War II and the Stalinist repressions were published and publicly discussed. The media channels devoted great coverage to this. And book publishing was also involved - printing manuscripts that could not appear earlier; reprinting prohibited books; and publishing books by Estonian émigré writers for the first time.

On the other hand, book reading and other cultural activities started to decline due to the massive growth of political and social activities. The results of our survey conducted in February 1990, indicate that in the course of a few years, $39 \%$ of Estonians started reading fewer books and $37 \%$ started buying fewer books (at the same time 10\% started more to read books and $14 \%$ more to buy) (Vihalemm \& Kumberg 1990).

In 1986 we predicted that the growing trend of consumerism could also cause the prestige of books in Estonia to decline (Lauristin \& Vihalemm 1986: 468). And this is what has happened since the mid-1990s, after the restoration of independence and the initial economic and social stabilisation.

The meaning of book buying and reading has completely changed in the whirlwind of societal changes following the restoration of Estonian independence in 1991, as has the role of all cultural spheres in everyday life and social development. The transformation from a planned to a market economy and the rapid reorientation from East to West were accompanied by a decline in national production by a third and serious economic troubles for many people. Prices rose, including the prices of books, which increased even more than the prices of newspapers and magazines; although, during the 1990s, the prices of the latter increased three times more than of other products.

Book reading has decreased and book buying has decreased even more. The focus on entertainment increased in all cultural spheres including in book demand.

\section{Contemporary trends in Estonian book consumption}

The restoration of independence and the development of 'normal capitalism' radically changed the meaning of all cultural spheres. The integrative and compensative functions of culture and media decreased, the cultural sphere became commercialised and fragmented (see Lauristin \& Vihalemm 2002).

The diversity of the publications increased, but the press circulation and average print runs of books declined.

Table 2 and Figure 1 indicate the dynamics of book publishing between 1987 and 2012, the number of published titles and average print runs per title. 
Table 2. Number of titles and average print runs of books published in Estonia, 1987-2012

\begin{tabular}{l|c|c|c|c|c|c|c|c|c|c|c|c|c|c}
\hline & $\mathbf{1 9 8 7}$ & $\mathbf{1 9 8 9}$ & $\mathbf{1 9 9 1}$ & $\mathbf{1 9 9 3}$ & $\mathbf{1 9 9 5}$ & $\mathbf{1 9 9 7}$ & $\mathbf{1 9 9 9}$ & $\mathbf{2 0 0 1}$ & $\mathbf{2 0 0 3}$ & $\mathbf{2 0 0 5}$ & $\mathbf{2 0 0 7}$ & $\mathbf{2 0 0 8}$ & $\mathbf{2 0 1 0}$ & $\mathbf{2 0 1 2}$ \\
\hline $\begin{array}{l}\text { Number of } \\
\text { books (titles) }\end{array}$ & 2250 & 2070 & 1654 & 1557 & 2635 & 3317 & 3265 & 3506 & 3727 & 4060 & 4310 & 4685 & 3760 & 3971 \\
\hline $\begin{array}{l}\text { Average print } \\
\text { run per title } \\
\text { (thousands) }\end{array}$ & 7.4 & 8.8 & 14.1 & 6.3 & 3.0 & 2.2 & 2.2 & 1.6 & 1.5 & 1.5 & 2.1 & 1.6 & 1.4 & 1.2 \\
\hline
\end{tabular}

Source: Vihalemm \& Juha 2004; Statistical Yearbook of Estonia 2008, 2013

\section{Changes in the diversity and average print run of books published in Estonia 1987-2012 $(\%, 1987=100)$}

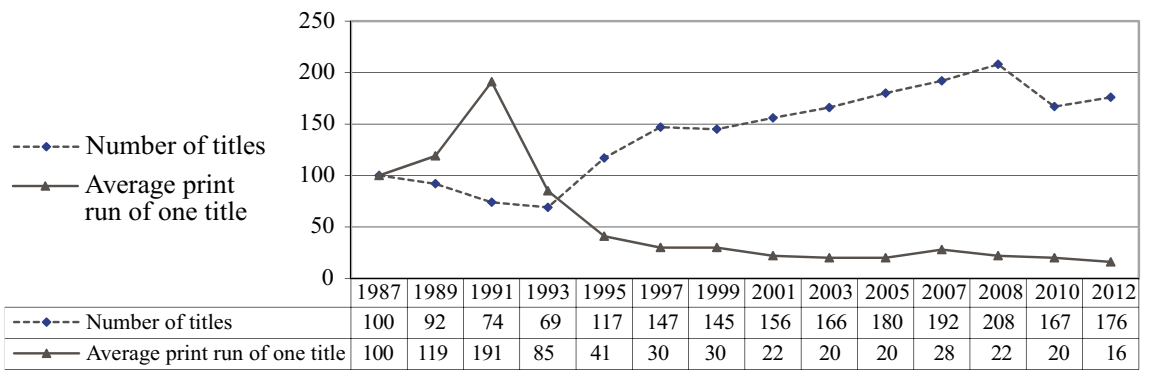

Figure 1. Number of titles and average print runs of books published in Estonia, compared to $1987(1987=100)$

Source: Vihalemm \& Juha 2004; Statistical Yearbook of Estonia 2008, 2013

The number of published titles decreased in the period of major political changes between 1988 and 1992 ("Singing Revolution" and re-establishment of independent statehood). The publishing of new titles started increasing again in 1993, and in 2008 and 2009, the rate doubled compared to 1987.

During the period of the mass liberation movement, the print runs of single titles increased, reaching 14,100 in 1991. After the restoration of independence, book demand felled quickly, and by the turn of the century, the average print runs were four to five times smaller than in 1987. Along with the economic growth after 2000, the average circulations of the printed press increased somewhat, but declined again during the economic crisis, reaching their lowest levels in 2011 and 2012.

The number of published books also started to decrease in 2009; the decline was halted in 2012, but the number of new titles is still lower than in 2007-2009. 
The structure of book production has changed. The share of fiction has increased from 13\% in 1990 (Järve 2002) to 27\% in 2000 and 2007 (Kultuur. Culture 1997-2007: 69). At the same time, the importance of domestic literature has diminished and that of translated foreign literature has grown. In Soviet times, the dominant source language for translations was Russian, but since the 1990s it has been English (68\% of all translated books in 2012, according to the data of the National Library).

In Soviet times, many genres of popular literature were officially labelled low-grade Western trash, although they were in great demand - crime novels, romances, fantasy and esoteric literature, etc. Practical self-help and hobby literature was also ignored. Since 1990s all these genres have been flourishing.

Table 3. Contacts with books of Estonians and Russophones in 2002 and 2011 (\% of population aged 15-74)

\begin{tabular}{r|c|c|c|c}
\hline & \multicolumn{2}{|c|}{ 2002 } & \multicolumn{2}{c}{ 2011 } \\
\cline { 2 - 5 } & Estonians & Russophones & Estonians & Russophones \\
\hline Reads fiction: & & & & \\
\hline sometimes & 33 & 29 & 34 & 34 \\
\hline very seldom, not at all & 39 & 28 & 42 & 42 \\
\hline $\begin{array}{r}\text { Reads professional or interest } \\
\text { literature: }\end{array}$ & & & & \\
\hline often, regularly & 31 & 30 & 23 & 19 \\
\hline sometimes & 38 & 30 & 36 & 30 \\
\hline Books at home: & 31 & 40 & 41 & 50 \\
\hline less than 50 books & 20 & 34 & 31 & 39 \\
\hline $50-300$ & 37 & 37 & 41 & 39 \\
\hline $300-1000$ & 34 & 22 & 21 & 17 \\
\hline over 1000 & 9 & 7 & 8 & 5 \\
\hline Books are usually bought: & & & & \\
\hline often, regularly & 5 & 7 & 6 & 3 \\
\hline sometimes & 38 & 41 & 31 & 30 \\
\hline very seldom & 37 & 36 & 33 & 32 \\
\hline practically not at all & 19 & 15 & 30 & 35 \\
\hline
\end{tabular}

Source: Institute of Journalism and Communication at the University of Tartu ${ }^{3}$

3 The sociological survey "Me. The World. The Media", in 2002 surveyed 1,470 respondents and 1,510 respondents in 2011, as a representative sample of the Estonian population aged 15 to 74 . 
During the Soviet period, many people bought almost all the new fiction that was published. Since 1990s very selective and pragmatic book buying has predominated. Many people prefer "to lend light fiction from the library and to buy book with more solid and permanent value: reference books, biographies, expensive poetry anthologies, etc. In a word, they prefer to buy something that is more elitist, with higher status or value, and/or valuable as a gift" (Järve 2002).

The share of regular fiction readers has decreased more than twice since the end of the $1980 \mathrm{~s}$, and according to our survey data it is still decreasing. In 2002 this share was 28\% among Estonians and 43\% among Russophones; in 2011 the respective numbers were $24 \%$ and $25 \%$. But the buying of books has declined even more than reading. The share of regular book buyers has decreased 10 times compared to the situation 30 years ago - in 2011 it included only $6 \%$ of Estonians and $3 \%$ of Russophones.

We can speak about a strengthening polarisation trend in book reading. According to the survey data of the Institute of International and Social Studies at Tallinn University, the share of the working population who had not read any books in the last year has grown from 3\% in 1985 to 14\% in 1998 (Järve 2002) and was $21 \%$ in 2007 according to Eurobarometer data. On the other hand, the share of heavy readers (read more than 12 books in the last year) has been greater than the share of non-readers - 29\% in $1985,20 \%$ in 1998 (Järve 2002) and 32\% in 2007 according the Eurostat Adult Education Survey (Cultural Statistics 2011: 180).

If earlier, during the 1970s and 1980s, the Russophones had a greater interest in fiction, than by 2011 their habit of reading fiction had declined to a similar level with the Estonians. Book buying and the size of home libraries have also equalised to a great extent: the share of book buyers has decreased in 30 years from $93 \%$ to $43 \%$ among Estonians and from $76 \%$ to $48 \%$ among Russophones. This has also caused a continuing decline in the size of home libraries - 30 years ago $51 \%$ of Estonian and $25 \%$ of Russophone households owned at least several hundred books while in 2011, the respective numbers were $29 \%$ and $22 \%$. Home libraries have also become smaller in Finland, but to much smaller extent - during the eight years from 1995 to 2003, the size of the average home library decreased from 300 to 260 volumes (Ekholm \& Repo 2010: 59).

Paraphrasing the words of Estonian poetry critic Mart Velsker, it can be said that the position of fiction has been marginalised threefold: the importance of fiction as reading matter has been reduced; the importance of literature in culture has been reduced; and culture has lost its central role in society as a means for selfrealisation, resistance and consumption (Järve 2002).

However, interest in books is still currently higher in Estonia than in many other European countries. 
According to Eurobarometer data from 2013 (Cultural access and participation 2013), 78\% of adults in Estonia have read at least one book during the last 12 months, thereby ranking Estonia in 6th position in the EU (Sweden was first with 90\%, the EU 27 average was 68\%). In 2007 Eurostat carried out the Adult Education Survey, and based on its data, Estonia ranked 3rd after Finland and Sweden based on the share of persons who have read more than 12 books during last year. According to the same survey, $53 \%$ of the Estonian population aged 25-64 had more than 100 books at home (3rd rank in the EU, Sweden was first with 57\%) (Cultural Statistics 2011: 178, 180).

Together with the decline in book buying the importance of libraries as a source of books for reading has increased, especially for Estonians. According to our last survey almost two-thirds of Estonians lent fiction for reading from libraries (38\% do so regularly, $26 \%$ occasionally) - see Table 4.

Table 4. Where do you get interesting fiction for reading? (\%, data of 2011)

\begin{tabular}{|c|c|c|}
\hline & Estonians & Russophones \\
\hline \multicolumn{3}{|l|}{ From the library: } \\
\hline often, regularly & 38 & 19 \\
\hline occasionally & 26 & 24 \\
\hline \multicolumn{3}{|l|}{ Reading books that we already have at home: } \\
\hline often, regularly & 24 & 25 \\
\hline occasionally & 49 & 48 \\
\hline \multicolumn{3}{|l|}{ Borrowing from a relative or friend: } \\
\hline often, regularly & 13 & 17 \\
\hline occasionally & 46 & 50 \\
\hline \multicolumn{3}{|l|}{ Buying: } \\
\hline often, regularly & 8 & 7 \\
\hline occasionally & 35 & 35 \\
\hline \multicolumn{3}{|l|}{ Electronic reading, e-books: } \\
\hline often, regularly & 2 & 8 \\
\hline occasionally & 7 & 17 \\
\hline
\end{tabular}

Source: Institute of Journalism and Communication at the University of Tartu

The popularity of e-books is Estonia still quite low, in the autumn of $20115 \%$ of population aged 15-74 has used the electronic equipment to read books and $23 \%$ is willing to do so.

In comparison, in 2012 the number of adult Americans reading e-books rose from $16 \%$ to $23 \%$ (Rainie \& Duggan 2012). In Europe the usage of e-books is much less lower, for instance, in spring of 2012, the share of e-book users in France was 5\% (Wischenbart 2013: 32); in Sweden in 2012 this share was 9\% (see Kersti Skans Nilsson's article in this publication); in Finland in the 
beginning of $20126 \%$ (see article of Juha Herkman and Eliisa Vainikka in this publication).

The situation in this area is changing very fast. IT companies and libraries are very actively creating new possibilities for e-reading. The level of digitalisation in Estonia is higher than in many other European countries - at the beginning of $2013,80 \%$ of households had broadband Internet connections (database of Statistics Estonia) and the share of tablet and smart phone users is growing rapidly.

It is interesting that e-books are more popular among Russophones (Table 4). The Russian e-books market is much larger and many more books are available electronically.

How large is the share of book readers in different social groups (Table 5)?

According to our survey conducted in 2011 reading is more popular among women than among men, $88 \%$ of women and $75 \%$ of men have read at least one book during the last 12 months; the share of heavy readers was $27 \%$ among women and $18 \%$ among men. This is related to men's smaller interest in fiction; the share of regular fiction readers among men is half that of women, $16 \%$ versus $32 \%$ respectively. However, there is no gender difference in the interest in non-fiction, and the share of regular readers is at the same level.

A higher percentage of middle-aged and elderly people compared to the younger generation read books generally, primarily fiction. The share of nonreaders is greatest in the 20-29 age group. This may be because they are occupied with other activities and do not have an obligation to read fiction as do high school students in the 15-19 age group do. The reading of non-fiction (professional and interest) literature in the 20-29 age group is at the same level as that of middle-aged and elderly people.

According to our data, education is the most significant factor determining book reading. The share of fiction readers and especially non-fiction readers among people with higher education is much bigger than in the other educational groups. The same has been observed in other countries, for instance in the U.S. (NEA 2013: 26).

\section{Interest in different kind of books}

According to the intensity of interest in the different kind of books, we can compile a pyramid of book demand with three general levels - the universal level at the bottom, differentiated level in the middle and specialised level at the top. Our book reading and book buying studies included the compilation of such a pyramid, based on the ranking of different kind of books according to the intensity of interest. 


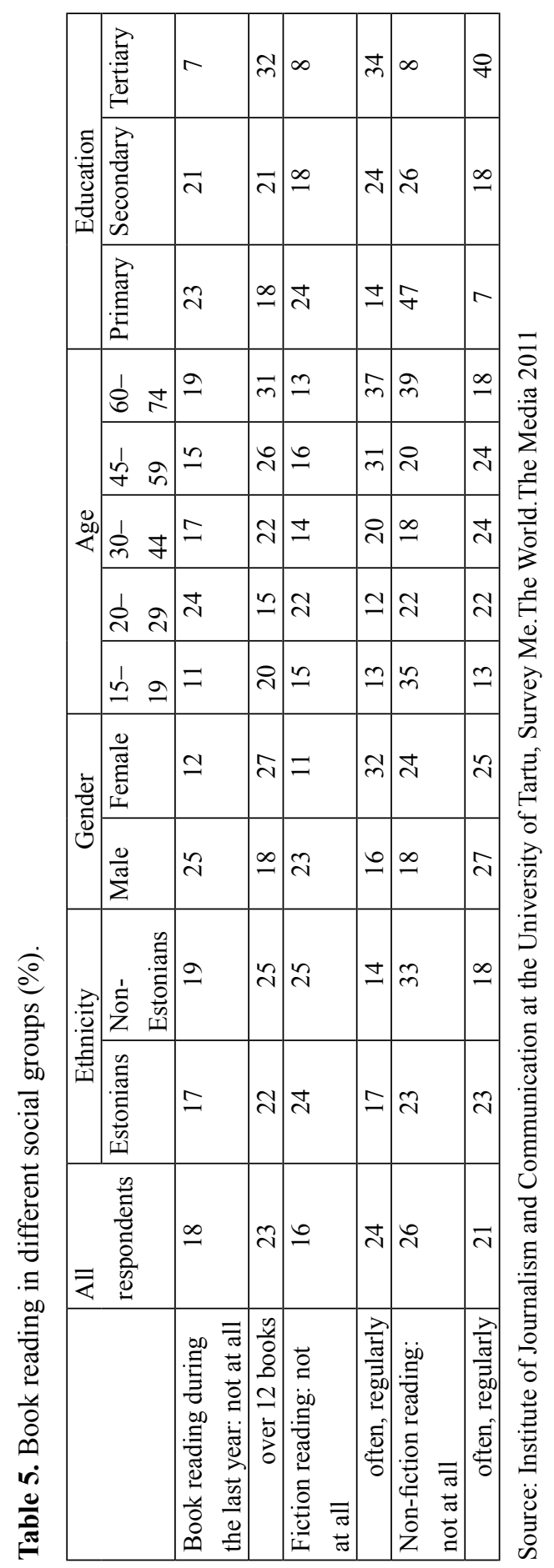


In Soviet times, analysing book demand was quite a practical task because of the large book deficit.

Between 1979 and 1984, the answers to the question "What kind of books are usually bought in your family?" were used an empirical indicator of the interest in different kind of books. Between 2002 and 2011, the corresponding question was "Please imagine that you are in a bookstore or library. Which shelf would you search for books that interest you?"

Despite the differences in the questionnaires (besides the questions, the classification of the books was also slightly different), we can still compare the rankings and distinguish levels of universal, differentiated and specialised book demand - Table 6 .

The universal level of the book demand pyramid has changed. In 1980s, the greatest interest was in recent fiction and practical books, Thirty years later, the literature of professional interest topped the list, followed by practical books, historical and biographical novels, memoirs and biographies. Reality-based books have greater appeal for today's readers than artistic fiction.

Great changes have occurred in book demand. The interest in fiction has dramatically declined. Thirty years ago, the greatest demand was for recent Estonian prose; many new novels were sold out almost immediately. Currently, Estonian prose ranks 16 th in the middle of the differentiated demand level. In the past, demand for recent foreign prose ranked $2^{\text {nd }}$, now it's $13^{\text {th }}$. Thirty years ago, classic fiction belonged to the universal demand level, today to the differentiated demand level. Poetry has moved from the differentiated demand level to the specialised level, from 24 th rank to $33 \mathrm{rd}$.

On the other hand, interest has increased in memoirs and biographies (from 14th rank to 7 th), and in books about history (from 23rd rank to 14th).

Thirty years ago the smallest demand was for ideology-related literature, and buying and reading it was often mandatory based on people's professional roles, for instance administrators, teachers, and students had to be familiar with it. However, its share among publications was quite large. The list of books published in 1975 included approximately the same number of fiction and ideological books -88 and 84 titles respectively. Later, the quantity of published fiction exceeded the quantity of ideological books (for instance, in 1979 the proportion was 126:76) (Kaints 1999: 1538). These figures are based on a categorisation that only included Marxist-Leninist texts as ideological literature. However, many other kinds of books also had a strong ideological and propagandistic bent. "The majority of books on history, economics and international relations were ideologically influenced to a such extent that it is very hard to classify them as specialised rather than ideological books" (ibidem: 1539). 
Table 6. Interest of Estonians in different kind of books, 1979-1984 and 2011

\begin{tabular}{|c|c|c|c|}
\hline \multicolumn{2}{|r|}{ 1979-1984 } & \multicolumn{2}{|r|}{2011} \\
\hline \multicolumn{2}{|c|}{$\begin{array}{l}\text { \% of respondents indicating that they sometimes } \\
\text { bought these kinds of books }\end{array}$} & \multicolumn{2}{|r|}{$\begin{array}{c}\text { \% of respondents indicating great interest } \\
\text { in these kinds of books }\end{array}$} \\
\hline $\begin{array}{r}\text { Level of } \\
\text { demand } \\
\end{array}$ & & $\begin{array}{l}\text { Level of } \\
\text { demand }\end{array}$ & \\
\hline \multirow{12}{*}{ 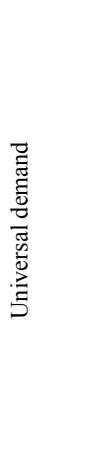 } & 1. Recent Estonian prose $90 \%$ & \multirow{10}{*}{ 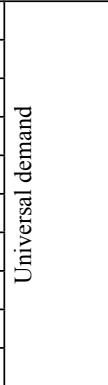 } & 1. Literature related to my specialty $45 \%$ \\
\hline & 2. Recent foreign prose $81 \%$ & & 2. Historical and biographical novels $34 \%$ \\
\hline & 3. Home economics, handicraft $78 \%$ & & 3. Health $33 \%$ \\
\hline & 4. Health care, medicine $76 \%$ & & 4. Food, cooking $30 \%$ \\
\hline & 5. Recent Soviet prose $75 \%$ & & 5. Reference books $29 \%$ \\
\hline & 6. Classic Estonian fiction $73 \%$ & & 6. Home, garden, handicrafts $28 \%$ \\
\hline & 7. Reference books, dictionaries $71 \%$ & & 7. Memoirs, biographies $26 \%$ \\
\hline & 8. Family, marriage $70 \%$ & & 8. Crime fiction, thrillers $26 \%$ \\
\hline & 9. Children's books 70\% & & 9. Interpersonal relations, behaviour $25 \%$ \\
\hline & 10. Classic foreign fiction $68 \%$ & & 10. Classic Estonian fiction $25 \%$ \\
\hline & 11. Nature, biology $67 \%$ & \multirow{13}{*}{ 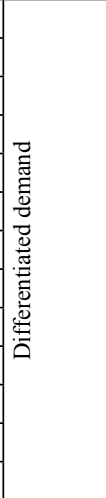 } & 11. Classic foreign fiction $23 \%$ \\
\hline & 12. Geography, foreign countries $67 \%$ & & 12. Romances $23 \%$ \\
\hline \multirow{14}{*}{ 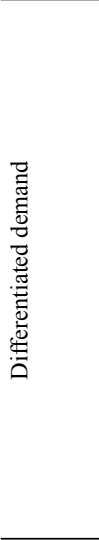 } & 13. Classic Russian and Soviet fiction $63 \%$ & & 13. Recent foreign prose $22 \%$ \\
\hline & 14. Memoirs, biographies $60 \%$ & & 14. History $22 \%$ \\
\hline & 15. Garden, apiculture $60 \%$ & & 15. Nature $20 \%$ \\
\hline & 16. Psychology, pedagogy $53 \%$ & & 16. Recent Estonian prose $20 \%$ \\
\hline & 17. Tourism, local history $52 \%$ & & 17. Cars, technology $20 \%$ \\
\hline & 18. Sport $49 \%$ & & 18. Family, children $20 \%$ \\
\hline & 19. Technology $48 \%$ & & 19. Construction, repair $19 \%$ \\
\hline & 20. Theatre, film $46 \%$ & & 20. Children's and juvenile books $17 \%$ \\
\hline & 21. Language usage, philology $45 \%$ & & 21. Mystery, horoscopes $17 \%$ \\
\hline & 22. Art, art albums $45 \%$ & & 22. Travel books $17 \%$ \\
\hline & 23. History $43 \%$ & & 23. Natural and life sciences $16 \%$ \\
\hline & 24. Poetry $37 \%$ & \multirow{12}{*}{ 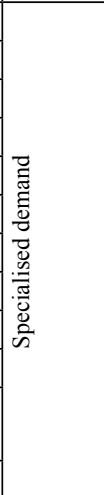 } & 24. Science fiction, fantasies $14 \%$ \\
\hline & 25. Current affairs $35 \%$ & & 25. Current Estonian history $13 \%$ \\
\hline & 26. Politics, international relations $34 \%$ & & 26 . History of ideas, philosophy, religion $12 \%$ \\
\hline \multirow{10}{*}{ 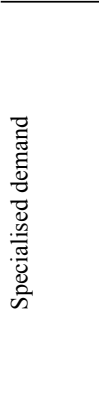 } & 27. Agriculture $30 \%$ & & 27. Sport $11 \%$ \\
\hline & 28. Juridical literature $30 \%$ & & 28. Art, architecture, design $10 \%$ \\
\hline & 29. Musical literature $29 \%$ & & 29. Music, film, television $10 \%$ \\
\hline & 30 . Dramas, plays $26 \%$ & & 30. Computers $10 \%$ \\
\hline & 31. Industry, construction, transport $25 \%$ & & 31. Literature, theatre, history of culture $9 \%$ \\
\hline & 32. Literary critics, history of literature $23 \%$ & & 32. Legislation, law $9 \%$ \\
\hline & 33. Economy, statistics, demography $19 \%$ & & 33. Poetry $9 \%$ \\
\hline & $\begin{array}{l}\text { 34. Mathematics, chemistry, physics, } \\
\text { astronomy } 18 \%\end{array}$ & & 34. Economy, management, marketing $7 \%$ \\
\hline & 35. Philosophy, sociology $17 \%$ & & 35. Politics, society $7 \%$ \\
\hline & 36. Administration, ideology $14 \%$ & & \\
\hline
\end{tabular}

Source: Surveys of the Department of Journalism/Institute of Journalism and Communication at Tartu University 
Much of the ideological literature, or the so-called "Red literature", was never sold. Not all the books published in Estonian during the Soviet period were in great demand or sold out quickly. This was true primarily of all fiction, children's books, consumer and reference books. As we can see from Table 6, thirty years later politics still attracts the least amount of interest.

In order to characterize book demand levels based on reasonable print runs, we can say that currently sales of 5,000 to 15,000 copies qualify books in Estonian for the universal demand level; 1,000-5,000 for the differentiated level; and under 1,000 for the specialised level. In the 1980s print runs of 40,000-150,000 copies would qualify books in Estonian for the universal demand level (Lauristin \& Vihalemm 1986). Actual printings rarely exceeded 40,000 (mainly due the paper deficit, and sometimes also due ideological reasons) and this caused large book deficits.

Looking at the list of bestsellers in 2012, we can see that 15 books were published that qualify for the universal level - three fictional books (Sofi Oksanen's When the Doves Disappeared [12,009 copies sold in 2012], 50 Shades of Grey by E. L. James [10,200 copies] and a new novel by Estonian writer Tõnu Õnnepalu, Mandala [7,154 copies]). The other twelve were nonfiction books (5,000-8,000 copies sold) with two new volumes of the new national encyclopaedia among them (8,100 copies) (Ojamaa 2013).

\section{In conclusion}

The large and mostly unsatisfied demand for books in Soviet Estonia should be seen as exceptional. The very high level of cultural activities can be regarded as an anomaly, which was generated by the Soviet Union's forcible political and economic assimilation. For Estonians (like for many other small nations in Soviet empire, but also for some Russophones), culture in one's native language functioned as an integrating mechanism that stood in opposition to the totalitarian political and ideological system and compensated for restricted political and economic activities. Books also had great prestige, participation in all cultural activities was very high and prices were low.

After the restoration of independence and the establishment of "normal capitalism", the emergence of an information and consumer society, the cultural mechanisms were activated that had characterised the Western countries for 30 years - the strong differentiation between elite culture and popular culture, a general decline in book demand with most people being interested only in entertaining bestsellers and practical publications, and not in more serious and demanding fiction.

In her summary article related to the three surveys conducted between 1993 and 2003, Malle Järve concludes that the period of decline in book reading, caused by the change in political system, had ended in Estonia by 1998, and 
reading activity had stabilised (Järve 2005: 165). However, our surveys demonstrate a slow decline in the interest in books until at least 2008 (in 2011 it was a couple of percentage points higher than in 2008). The decline between 2002 and 2008 was much smaller than between 1990 and 2002, but the questions related to stabilisation will remain unanswered until we will receive the data from our next survey, which is planned for autumn 2014.

Malle Järve also concludes that "characteristically of the information era, the structure of reading interests has shifted toward non-fiction literature, and the share of information-rich literature in reading has grown" (ibidem). While not challenging this general trend, based on our survey results we can say that there is increased interest in practically oriented literature, but not in professional and interest literature. The data in Table 3 even indicates the opposite trend. However, there is a problem related to the formulation of the question on 'professional and interest literature' in our survey, as this formulation does not include all kinds of non-fiction.

In contemporary Estonia, e-books are not yet competitive with printed books, but the situation can change in only a few years due to the high digitalisation level and rapid spread of new information technology in Estonia.

\section{Acknowledgements}

The research was supported by grants of Estonian Science Foundation (8329) and Estonian Research Council (IUT20-38).

\section{References}

Arutjunjan, J. \& Kahk, J. (Eds.) 1980. Sotsioloogilisi suletõmbeid Nõukogude Eesti kohta (Sociological characteristics of Soviet Estonia). Tallinn: Perioodika.

Bradshaw, T., Nichols, B. \& Bauerlein, M. (2004). Reading At Risk: A Survey of Literary Reading in America. National Endowment for the Arts. - www.nea.gov/ pub.readingatrisk.pdf (20.09.2013)

Cultural access and participation 2013. Special Eurobarometer 399. - http://ec.europa. eu/public_opinion/archives/ebs/ebs_399_en.pdf (18.02.2014)

Cultural Statistics 2011 edition. Eurostat Pocketbooks - http://epp.eurostat.ec.europa. eu/cache/ITY_OFFPUB/KS-32-10-374-EN.PDF (12.09.2013)

Database of the Statistics Estonia - www.stat.ee

Ekholm, K. \& Repo, Y. (2010). Kirja tienhaarassa vuonna 2020. Helsinki: Gaudeamus Helsinki University Press.

European Cultural Values. Special Eurobarometer 278 (2007). - http://ec.europa.eu/ public_opinion/archives/ebs/ebs_278_en.pdf (12.09.2013)

Gedin, P. (1982). Literature in the Marketplace. Norfolk: Faber \& Faber.

Gotowska, A. (2011). Poland: The State of Reading. Global Voices, 28 July - http:// globalvoicesonline.org/2011/07/28/poland-the-state-of-reading (15.08.2013)

Herkman, J. \& Vainikka, E. (2012). Lukemisen tavat. Tampere: Tampere University Press. 
Hoyer, S., Lauk, E. \& Vihalemm, P. (Eds.) (1993). Towards a Civic Society: The Baltic Media's Long Road to Freedom. Tartu: Baltic Association for Media Research/Nota Baltica.

Järve, M. (1985). Kulturnaya deyatelnost naselenija (Cultural activities of the population). Tallinn: Eesti Raamat.

Järve, M. (2002). Changes in Reading Culture in Estonia in 1990s. Paper presented for the international Writing and Reading Seminar, April 11th-13th, Jyväskylä. - www. ies.ee/reading.doc (13.09.2013)

Järve, M. (2005). Raamatulugeja siirdeaja Eestis (Book reader in transformation-time Estonia). In E. Uverskaja, L. Aarma (Eds.), Informatsioon, kommunikatsioon, ühiskond. Tallinna Ülikooli Toimetised, A26 Humaniora. Tallinn: Tallinna Ülikool.

Kaints, H. (1999). Ajas muutunud raamat, raamatu ümber muutunud aeg (Changed book, changed time). Looming, 10, 1536-1549.

Knulst, W. \& Kraaykamp, G. (1997). The decline of reading. Leisure reading trends in the Netherlands (1955-1995). gerbertkraaykamp.rohosting.nl/Pdf_files/1997_NJS.pdf (15.08.2013)

Kononova, S. (2011). A Disappearing Habit. http://russiaprofile.org/culture_living/40137.html (13.08.2013)

Kultuur.Culture 1997-2007 (2009). Tallinn: Statistics Estonia.

Lauristin, M. \&Vihalemm, P. (1985). Eestlane raamatuostjana (Estonians as book-buyers). Looming, 2, 247-256.

Lauristin, M. \& Vihalemm, P. (1986). Raamatunõudlus ja kirjanduskultuur (Book demand and literary culture). Keel ja Kirjandus, 7 and 8, 385-394, 459-486.

Lauristin M. \& Vihalemm, P. (2002). The Transformation of Estonian Society and Media: 1987-2001. In P. Vihalemm (Ed.), Baltic Media in Transition. Tartu: Tartu University Press.

NEA 2013 - How a nation engages with art. Highlights from the 2012 survey of public participation in the arts. NEA research report no 57. arts.gov/sites/default/files/highlights-from-2012-SPPA.pdf (19.09.2013)

Nordicom 2012. Mediadagen 1979-2011. www.nordicom.gu.se/mt/filer/mediadagen_1979-2011.pdf(15.09.2013)

Ojamaa, H. (2013). Vaata mullu enim müüdud raamatute edetabelit (Ranking list of best-selling books of 2012). Postimees, 1.02 .

Perekond ja kultuur (Family and culture) (1985). Tallinn: Eesti Raamat.

Rainie, L. \& Duggan, M. (2012). E-book Reading Jumps; Print Book Reading Declines. Press release 27.12.2012. - http://libraries.pewinternet.org/2012/12/27/e-book-reading-jumps-print-book-reading-declines/ (15.09.2013)

Rainie, L., Zickuhr. K., Purcell, K., Madden, M. \& Brenner, J. (2012). The rise of e-reading. - http://libraries.pewinternet.org/2012/04/04/the-rise-of-e-reading (15.09.2013)

Rubinova, E. (2010). Books on Russia: Readers Versus Twitts. - www.passportmagazine.ru/article/1826/ (13.08.2013)

Statistics Sweden (2007). Fewer and fewer men read books. Press release from 2.07.2007. - www.scb.se/Pages/PressRelease_192418.aspx (15.08.2013)

Statistical Yearbooks of Estonia 1990-2013. Tallinn: Estonian Statistics.

Suomi lukee (2009). - www.kustantajat.fi/attachments/2009-01-30T11-02-4338pdf (14.09.2013) 
Tilastokeskus (2011). Ajankäyttötutkimus 2009. Lukeminen. www.stat.fi/til/akay/2009/03/akay_2009_03_2011_05_17_kat004_fi.html?tulosta (14.09.2013)

Vihalemm, P. \& Juha, L. (2004). Lisa 3. Trükisõna ja lugejad (Appendix 3. Printed media and readers). In P. Vihalemm (Ed.), Meediasüsteem ja meediakasutus Eestis 1965-2004. Tartu: Tartu Ülikooli Kirjastus.

Vihalemm, P. \& Kumberg, E. (1990). Trükisõna leviku ja efektiivsuse seaduspärasused Eesti NSV elanikkonna erinevates gruppides. Lepingulise töö aruanne, käsikiri (Spread of the printed media in different social groups in Estonia. Manuscript of the research report). TRÜ zhurnalistika kateeder.

Wischenbart, R. (2013). Global eBook. A report on market trends and developments.www.wischenbart.com/upload/the_global_ebook_report_fall2013_final04-2edi-pdf. pdf (25.10.2013) 


\title{
Reading as lifestyle
}

\author{
Marju Lauristin
}

\section{Introduction}

The fate of books and reading in contemporary Estonia is shaped by three overlapping transformations: the movement from the Communist regime to a free market society; the transformation of the entire national culture by international trends related to globalisation and post-modernity; and the changes in the technological means of cultural communication, whereby a shift has more or less been made from traditional media to new digital media (Lauristin 2013).

One could say that of these trends, at least the latter two are common to the cultural situations in all Western countries. However, if in the UK, France, Sweden or Finland, for example, the cultural shift toward globalisation and the post-modern cultural paradigm emerged in these stable welfare societies quite slowly, being among the central themes of the critical cultural debate since 1970s, in the post-Communist countries like Estonia these cultural changes had taken place two decades later within the framework of a revolutionary turmoil the encompassed the whole society. The overlapping of post-Communism with post-Modernism was coupled with a technological revolution. 'E-society' has become the trademark of the 'new Estonia' (see Runnel, PruulmannVengerfeldt \& Reinsalu 2010). At the same time, traditional forms of culture, which during Soviet time were oppressed and restricted by Communist ideological control, also started to flourish under the new conditions of democracy and freedom - at least in terms of diversity, if not of access. In transforming societies the features of modernity and late modernity are blended in a variety of lifestyles and identities (Giddens 1991). This is also true of post-Communist societies (Allaste 2013). The new cultural situation offered a plenitude of competing choices, and restrictions were created not by the scarcity of cultural content, but primarily by economic inequality and the lack of material resources (see also Peeter Vihalemm's article in this publication). The diversification of cultural production is positively related to emerging new class distinctions. This new situation challenges researchers to monitor the participation of people in various cultural forms in terms of their personal self-realisation as a dimension of their lifestyles. Cultural practices, including reading books and the printed 
press, or a preference for digital media also become an important indicator of the new social divisions in society (Bourdieu 1984/2010, Di Maggio, 1987)

In this paper, we look at the practices related to books and reading as one of the important indicators of the changing lifestyles of Estonians. We have had an opportunity to monitor the book preferences and reading habits over two decades. In Estonia, the empirical studies in this field go back to the 1980s and reflect the readers' reading preferences in the Soviet period. The most complete database related to the empirical study of book consumption and lifestyle, which allows a comprehensive comparison to be made with present-day data, is available at the University of Tartu from the sociological data archive that dates from 1990. This line of research has been continued in the waves of national surveys called 'Me. The World. The Media' that have been conducted triennially since 2002 by the University of Tartu's Institute of Journalism, Communication and Information Studies. In particular, the surveys from 2002, 2005 and 2011 included extensive set of indicators related to cultural participation, including reading habits and book preferences (Lõhmus, Lauristin \& Salupere 2004; Lõhmus, Lauristin \& Siirman 2010). Some of the data are analysed in this paper. ${ }^{1}$

The main issues discussed in this paper include the following:

- What are the main structural factors in the diversification of the reading patterns?

- How are the reading patterns related to the diverse lifestyles?

- What is the role of gender in the formation of lifestyles and the related reading preferences?

- How are the reading preferences and lifestyles of different generations influenced by the new opportunities of cultural participation offered by the digital media environment?

- How have the post-Communist changes in Estonian society influenced the role of reading in the Estonians' lifestyles?

\section{Theoretical framework}

Our analysis is inspired by Bourdieu's understanding of cultural practices as a special field. According to Bourdieu, the practices in the cultural field are structured according to specific criteria and rules of cultural production and appropriation, which are based on cultural values (Bourdieu 1993). The concept of habitus, developed by Bourdieu, reflects the intimate relationship between

\footnotetext{
The survey 'Me.The World.The Media 2011'. Survey design: written questionnaire + oral interview. Representative national sample, two languages (Estonian and Russian), age 15-74, 1510 respondents. Financing: Estonian Ministry of Education and Science, Estonian Science Foundation.
} 
social background and the cultural dispositions of individuals. Effective participation in the cultural field provides an opportunity to increase cultural capital. Structural factors like education and social background create dispositions favourable for the accumulation of cultural capital in the higher strata of society, and thereby creating a correlation between social and cultural stratification (Bourdieu 1984/2010; Lash 1994: 153-156; Bennett et al 2009: 25-27). Departing from Bourdieu's conceptual framework in our empirical studies, we apply the concept of lifestyle as an analogue to the concept of habitus: a lifestyle is a pattern of dispositions concerning the preferences of the respondents and importance they place on certain (pastime) activities, which are also related to social context (Allaste 2013:10). We assume that differences in lifestyles are, on the one hand, formed by the different cultural capital of the individuals formed during their lifetimes by family, education and other factors of social context; and on the other hand, by the actual availability of opportunities, institutional pressures and restrictions in society.

Among other cultural media, books offer the most universal and diverse opportunities for cultural participation, and, for that reason, are one of the most informative indicators of cultural differences among people. Looking at cultural and social differences in Britain through the lens of Bourdieu's theory, Bennett et al (2009) have stated that reading remains a crucial avenue, or intermediation, for the accumulation of cultural capital. Griswold speaks about the 'reading class' as a kind of cultural elite in each society. He points out the problem, which is also in the focus of our research - if for Bourdieu the most important divide in cultural capital was caused by educational differences, in contemporary society the change in cultural dispositions coincides with generational change. Educated people still read the most, but in younger cohorts, reading by the highly educated has declined just as much as by their less-educated peers (Griswold et al 2005).

\section{Social context of cultural consumption and book preferences}

According to Bourdieu, social class (coupled with educational differences) is the most important structural factor of cultural distinction. In his empirical analysis Bourdieu has proven the correlation between class structure and stratification in the cultural field (Bourdieu 1984/2010:101). But in the contemporary world, due to the diversification of cultural choices and the recognition of the (sub)cultural varieties of cultural production and consumption, Bourdieu's model of vertical cultural stratification has been criticised as becoming questionable in the new cultural conditions of the post-modern societies (Bennett et al 2009: 39; Warde 2011: 84). If in modern societies the hierarchy of cultural preferences (tastes) was categorised in direct concordance with the 
vertical hierarchy of the social-economic structure from 'low' to 'high' (Gans 1999), in the post-modern situation, it is more appropriate to apply the pluralist model of horizontal segmentation when analysing diverse lifestyles. In the post-Communist societies the application of the class-related model of cultural stratification becomes even more complicated due to the different paces of change in the social, economic and cultural fields (Offe 1996, Dahrendorf 1990). If in the stable, established capitalist societies the class-related vertical cultural divisions seem to amalgamate into 'normal' middle class culture and the new cultural formations emerge mostly as alternative subcultures belonging to the same 'middle' level of society (Lawler 2011: 6-8), in the 'new' postCommunist societies, the formation process of social stratification based on the capitalist economic divisions in society is still incomplete and the new middle class with its 'naturalised' standards of cultural participation has not yet fully emerged. In a post-Communist culture the 'naturalised standards' of cultural consumption are more likely to reproduce patterns created during the Soviet period, when 'normal' meant active cultural participation, and when consumption of 'high culture' was available to and popular among the entire population (for example, according to our data from 1970s and 1980s, reading classical and modern literature was widespread among all social groups, see Peeter Vihalemm's article in this publication). At the same time, the exposure to global cultural trends and the increasing supply of diverse cultural production are contributing to the rapid fragmentation of cultural consumption and the formation of the new patterns that cannot be attributed to emerging class divisions but rather to multiple other axes. Among them, generational change seems to be the most significant reason for the creation of cultural differences in fast transforming post-communist societies like Estonia. Estonia and the other Central and Eastern European countries have been going through simultaneous and very rapid political, economic and technological transformations during the same, relatively short, historical time span. One of the outcomes of this transformational process is a deep generational gap pervading the entire cultural field (Kalmus, Masso \& Lauristin 2013). Moving from a state-controlled society to a free market one, the older generations have retained many of the features that characterised cultural consumption during the previous type of society: the great prestige of 'high culture'; the habit of reading a lot of fictional literature; and a strong belief in the educational value of traditional forms of culture (Lõhmus, Lauristin \& Salupere 2004). The importance of culture in general has remained higher among the over-45 age groups. However, the social importance of 'established' vs. 'emerging' tastes, c) gendered tastes and d) voracity vs. selectivity related the arts, including literature, has especially decreased. The rapid decline of reading among the whole population, but especially among the 'after-1989' generations, is one of the most dramatic cultural changes in Estonia, as well as in many other countries (Lauristin 2013). On the one hand, 
young people are seeking alternative ways of emotional self-expression, like music, computer gaming, online communication, films etc. But it is not only new media technologies that lead young people away from reading books. It is the general changes in lifestyle that take the younger and more active people away from the bookshelves: more travelling, different means of entertainment, but also greater time pressures at work and on leisure time. The change in the dominant core of society's cultural transmission from the printed word to audiovisual and digitalised forms implies significant alterations in the mechanisms of cultural integration in society (Vihalemm, Lauristin \& Kõuts 2012).

Bennett et al have analysed the patterns of cultural consumption in the UK today and have pointed out four relevant axes for the sociological description of the varieties of book culture: a) the level of participation (active usage vs. non-usage, b) to genres (Bennett et al 2009: 97-98). In our analysis of the empirical data related to the linkages between book consumption and the more general characteristics of lifestyle, we have applied a relatively similar multidimensional approach to the cultural field, comparing the levels of active cultural participation and the selectivity of book preferences with the status- and gender-related patterns of lifestyles and generational differences.

\section{Empirical results}

\section{Social characteristics of book consumption}

Our data confirm that the people who feel they belong to the higher social strata in Estonian society (the 'reading class' according to Griswold) consider culture and the regular reading of fictional and non-fictional literature to be important. As our respondents rose up the vertical ladder of subjective social position, they affirmed a higher rate of attendance at cultural events, stronger belief in the importance of culture and more intense reading habits, especially of non-fiction and professional literature (Figures 1 and 2).

This status-bound difference reveals a vertical dimension of cultural stratification, which is mostly related to the dependence of cultural activities on the level of income. At the same time, the gendered pattern of cultural participation revealed the reversed tendency: as opposed to the male domination of political and economic affairs in Estonian society (leading positions of men in top management, the largest gender gap in incomes in the EU, etc.), Estonian women are in the leading positions when it comes to cultural activities. Estonian women are 2.5 times more likely to achieve a higher level of education than men (Heidmets et al 2011: 103). This education gap is one reason why, in almost all the spheres of cultural activity, Estonian women are ahead of men. 
The role of culture: important or unimportant? (\% among self-defined strata)

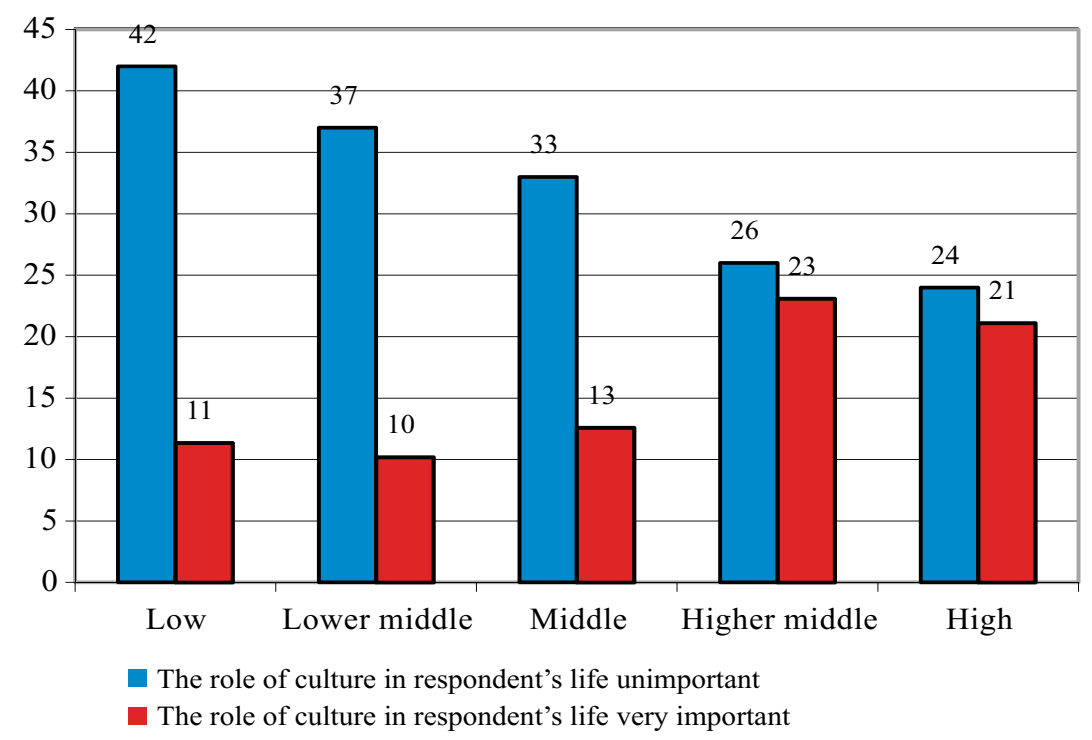

Figure 1. Importance of culture among self-defined strata

\section{Professional and other non-fiction reading by strata}

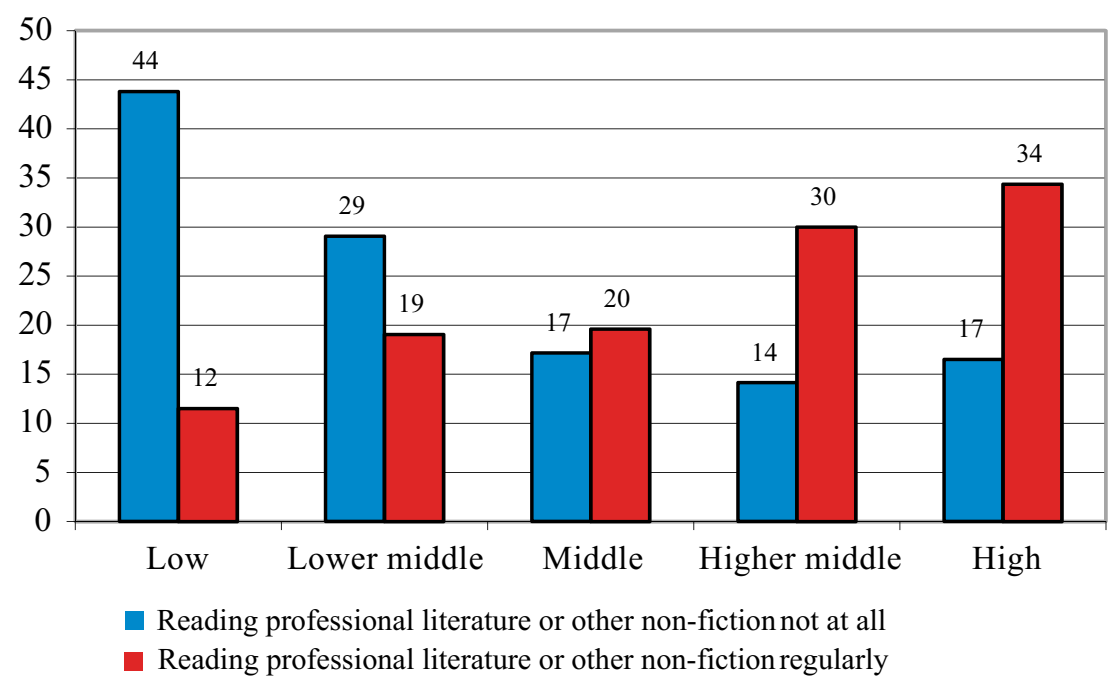

Figure 2. Reading of non-fiction by strata. 
Gender differences related to cultural consumption, the recognition of national and international writers and the interest in more or less sophisticated foreign authors

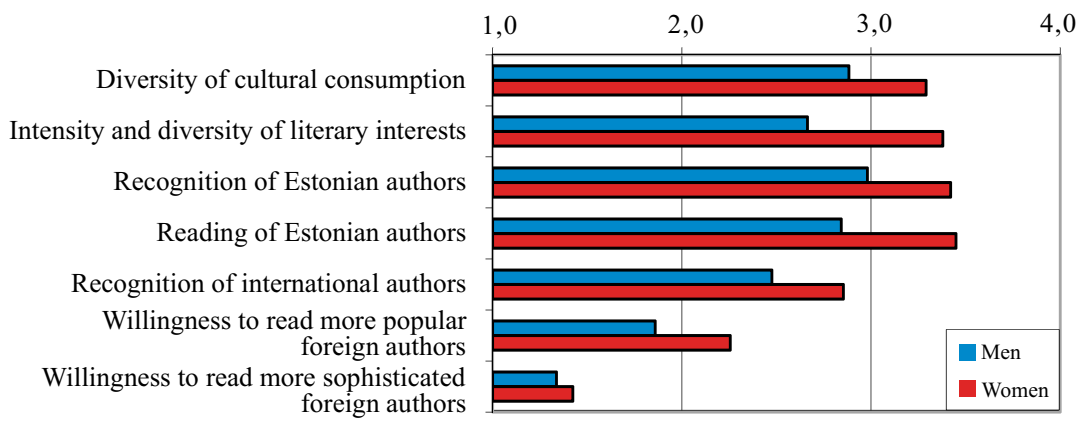

Figure 3. Gender differences, related to cultural consumption and the reading of national and foreign authors

Male and female book preferences (average factor scores by gender)

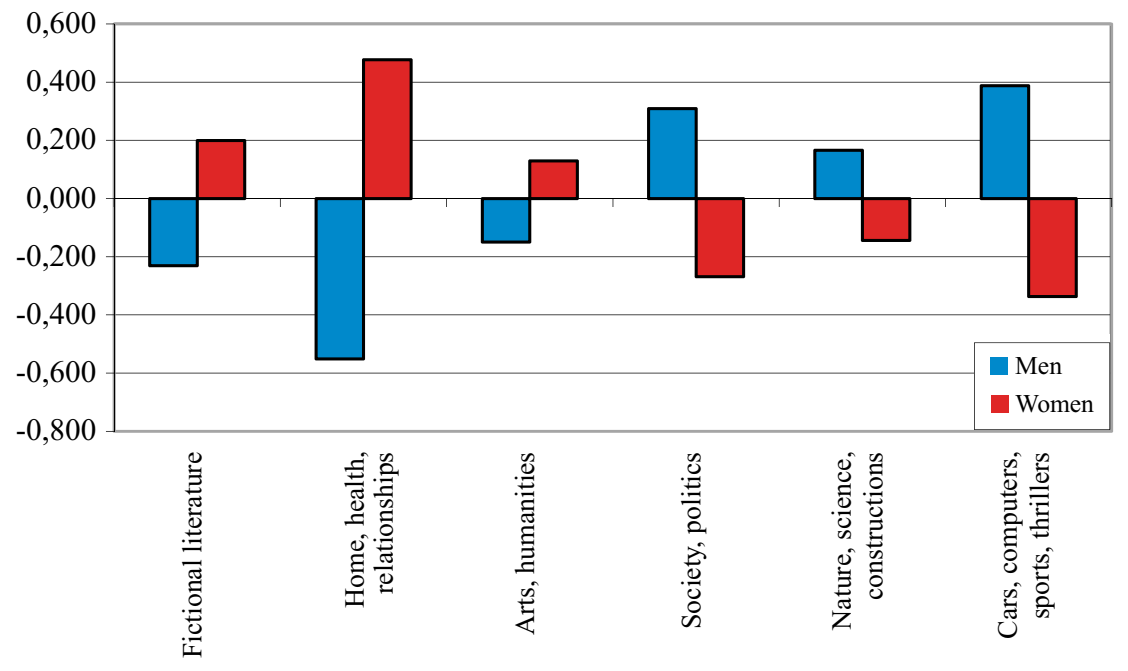

Figure 4. Male and female book preferences (results of factor analysis)

In Figure 3, we see that women have developed a more diverse pattern of cultural consumption in general and in reading preferences specifically. However, when comparing book preferences by content, connections with the male domination of public life become clearly visible: men are more interested in books 
about society and politics, technology, science and sports, whereas women prefer fictional literature, books about the home, family, human relations, arts and culture. As far as fictional literature is concerned, thrillers are the only books that men are more interested in than women (Figure 4).

As stated above, societal transformations have amplified generational divisions in the field of culture. One of the most visible differences is related to the decline in literary reading (Figure 5). Among the respondents belonging to the 15-29 age group, which has been socialised in the new technological and cultural environment, more than $20 \%$ do not read any literary texts and only 10 $12 \%$ are regular readers; while among the oldest group (aged 60-74), over $40 \%$ are regular readers and only $12 \%$ are non-readers (Figure 5 ).

\section{Age differences related to the interest in reading fictional literature}

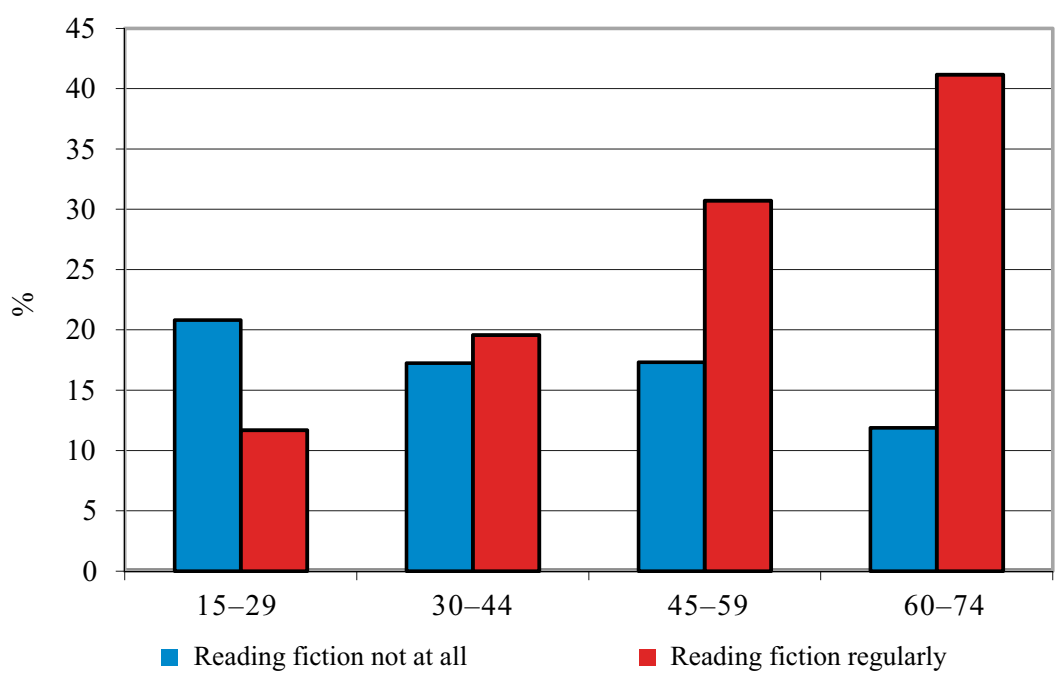

Figure 5. The reading of fiction in various age groups

The generational changes are not limited to reading habits but also include other cultural activities. In order to relate the changes in book reading to the entire pattern of cultural participation in the new societal and technological context, we applied a multidimensional classification (K-means cluster analysis) to our respondents according to the following indicators ${ }^{2}$ :

- the general importance of culture and books

- book consumption preferences (factor scores of thematic book choices)

2 Detailed information about the indicators and components of book preference and lifestyle factors are presented in Appendices 1, 2 and 3. 
- pastime activities, including the regularity of reading fiction, non-fiction and professional literature, various hobbies etc. (factor scores of lifestyle indicators)

- usage of traditional and new media

The preliminary analysis revealed statistically meaningful correlations between the factors related to book preferences and the categories of social structure (Table 1).

Table 1. Correlations (Pearson, $p<0.01$ ) between the factors related to book preferences and social-demographic categories

\begin{tabular}{l|c|c|c|c}
\hline & Gender M-F & Age & Education & Social status \\
\hline F1 Fiction, history & 0.215 & 0.179 & 0.201 & \\
\hline F2 Home, health, family & 0.513 & & & \\
\hline F3 Humanities, arts & 0.139 & -0.189 & 0.208 & 0.186 \\
\hline F4 Science, technology, reference & -0.288 & 0.250 & 0.105 & \\
\hline F5 Economy, politics & -0.155 & & 0.111 & 0.102 \\
\hline F6 Computers, cars, excitement & -0.362 & -0.324 & & \\
\hline
\end{tabular}

From the table we can again see the very clear gendered structure of the book choices, which reveals that a very conservative cultural pattern still prevails in this area. But, some of the surprising correlations that we see between book choices and age seem to show that, the younger generation is challenging this tradition. It seems that, in the younger generation, an interest in the humanities and arts, which is generally more connected to the female pattern, is not inconsistent with an interest in computers, cars or thrilling experiences. As expected, education is positively correlated with more intellectual patterns of book preferences, including quality fiction, arts, sciences, politics and economy, and less with excitement and home-centred practical knowhow. Social status is supported by reading 'serious books' and showing interest in the humanities and arts.

\section{Typology of reading-related lifestyles}

The results of the cluster analysis were interpreted as patterns of reading-related lifestyles. The respondents were grouped into six clusters. The next task was to clarify, how the clusters are related to certain social categories like gender, age, economic and professional status etc. Combining the reading and lifestyle patterns with the social background of the clusters allows us to present the typology of reading-related lifestyles, which is organized around the five axes: a) level (active-moderate-passive) and the format of cultural participation (importance and intensity of contacts with books and other, new or traditional cultural media), b) the character of book preferences (voracity vs. selectivity) 
and thematic choice (quality fiction, mass fiction, humanitarian or scientific nonfiction, technical/practical reference, professional); c) subjective social status (upper, upper-middle, middle, lower-middle, lower) and objective status factors like income and education; d) gendered structure; e) generational structure.

In following section, we present six types of reading-related lifestyles:

A New multi-active non-fiction reader (18\% of respondents)

B Traditional active humanitarian reader (19\%).

C Traditional recreational and practical reader (17\%).

D New moderate hobby- and entertainment-oriented reader (23\%).

E New hedonistic Internet-oriented non-reader (11\%).

F Traditional passive non-reader (12\%).

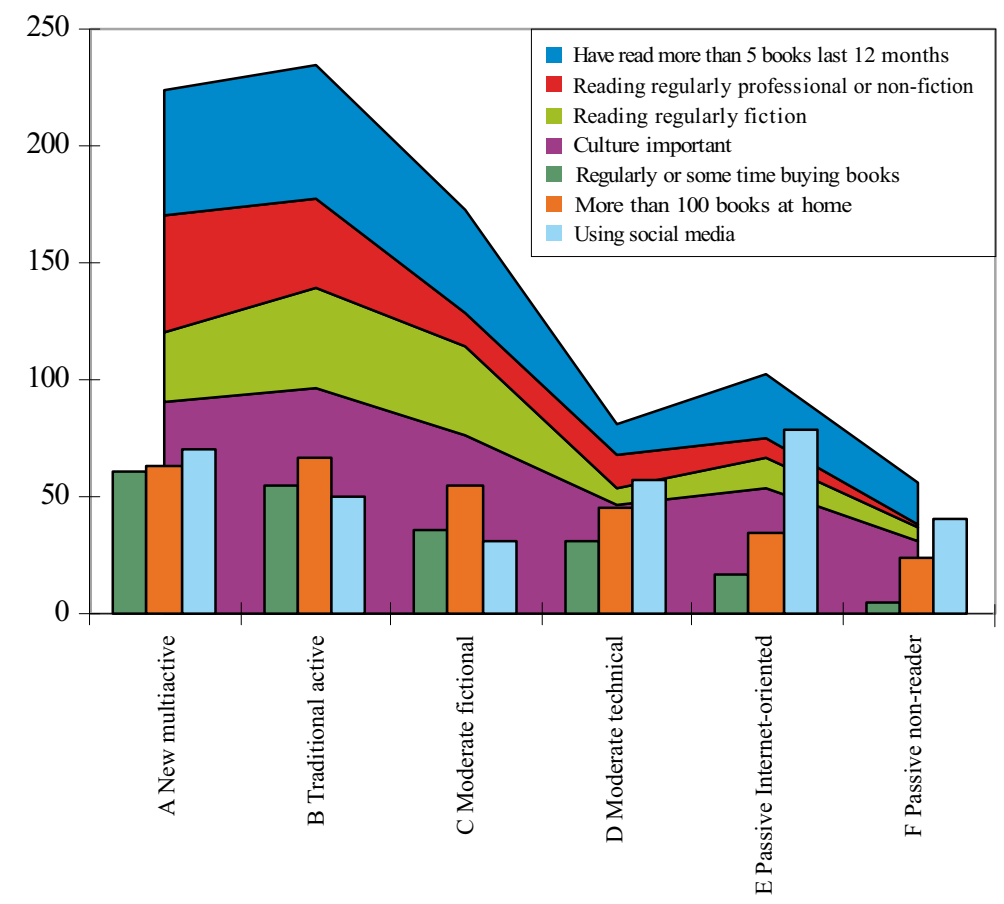

Figure 6. Book consumption characteristics of the reading-related lifestyles

Figure 6 illustrates the relationships of these six lifestyle types with book consumption. The first two (A and B) are both active readers that have respectable libraries at home, which are regularly updated. The difference between the fictional vs. non-fictional book preferences of these two active types is based on their gender, while the other specific feature - the more or less active usage of the new media - is related to age. The latter is also a determining factor when 
comparing the two passive types $\mathrm{E}$ and $\mathrm{F}$. Both are practical non-readers (we have to take into account, that there are a large number of secondary school students in the youngest type E, whose reading outside classroom is very poor), but the youngest type $\mathrm{E}$ is actively involved in the virtual world where they also find their means of self-expression, as well as cultural and social participation. Type $\mathrm{F}$ is the opposite - here traditional media is the only means of cultural and social participation, and the lack of interest and activity in traditional media means that almost total social exclusion.

\section{Average scores of the lifestyle factors in the reading-related lifestyle clusters}

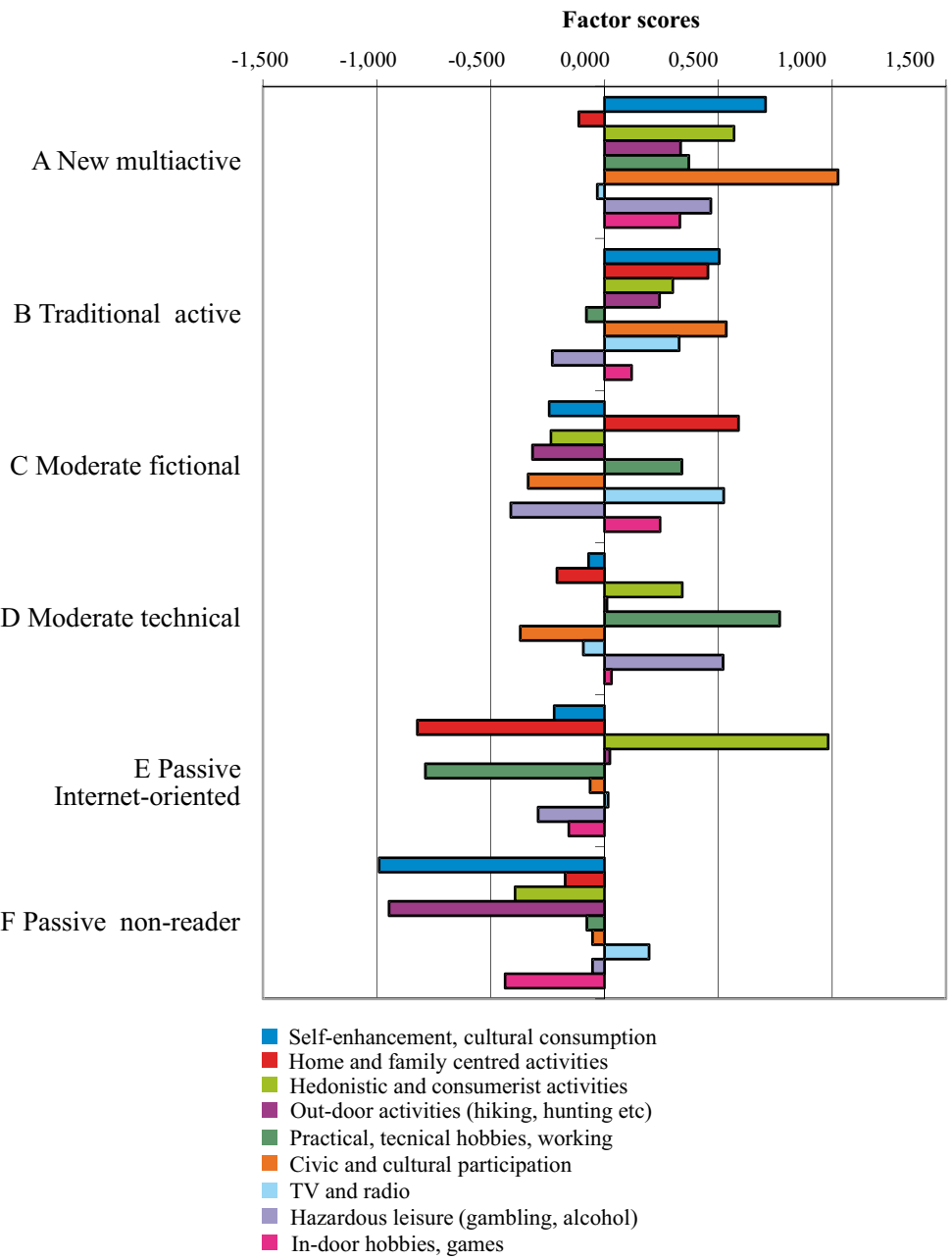

Figure 7. Pastime activities characterising the types of reading-related lifestyles 
The profiles of the pastime activities in the two active reading types A and B are characterised by active cultural consumption and also by a higher level of civic participation (Figure 7). The results of the cluster analysis have thus confirmed our assumption that that an active interest in books is part of more general culturally active lifestyle and represents a specific kind of personal habitus.

The full description of the typology of reading-related lifestyles is the following:

Type A: New multi-active reader (omnivore) (18\% of respondents). This type represents the new multi-active young 'reading class' - people who continue to read large numbers of all kind of books and buy new books more often than most people. At the same time they are fully acclimated to the world of computer technology, actively use social media and are starting to read e-books more often than average Estonians. For this type of person, reading is an important dimension of their self-enhancement. Their book preferences are informed by their professional activities and biased toward non-fiction; specific preferences are books on the economy, society and politics, but also on the arts and sports. Interest in politics is also reflected in their media usage: they regularly follow the news, documentaries and discussions on public affairs. The fictional literature that this type of readers prefers includes modern novels or science fiction, but they also enjoy classical literature and they sometimes read the cultural press and popular science magazines.

Young people who are heading towards the top of their careers comprise the largest share of this type ( $43 \%$ are under 30$)$. Many already belong to the managerial and professional elite. This group lives an urban and recreational lifestyle. They participate in the broad range of civic and cultural activities and training courses, as well in various cultural and sporting events and outdoor activities (hiking, hunting, fishing etc). This type is characterised by a higher social position and higher educational level. Twenty-eight percent of the people in this group feel they belong to the top of Estonian society. Men are slightly in the majority.

Type B: Traditional active humanitarian reader (19\%). These are well-known book-loving types that spend a large part of their leisure time reading novels, biographies, poems, general interest magazines and books on the arts, culture and history. At the same time, they also read quite a lot of professional literature, maybe somewhat less than type A, but still more than all the other types. Similarly to type A, reading books plays an important role in their self-enhancement. They have the largest home libraries and also buy new books regularly. Compared to type $\mathrm{A}$, this category is a bit more conservative in their preferences, particularly since they do not use computers and Internet resources very much outside their jobs. Their leisure activities are more home-centred and less consumerist, but they are very active in the cultural area, often going to the theatre, concerts, exhibitions etc. This group is comprised primarily of middle-aged, 
highly educated professional women, who more often than the average reside in the capital city. Their self-assessment is more modest than type A's, and the majority feel they belong to the middle of Estonian society rather than the top.

Type C: Traditional recreational and practical reader $\mathbf{( 1 7 \% ) . ~ T h i s ~ g r o u p ~ i s ~}$ comprised primarily of older women ( $58 \%$ are over 55 ) belonging to the middle or lower strata of contemporary Estonian society. Their great interest in reading fiction dates back to Soviet times; they have a large number of books from that time in their homes, and sometimes also buy new books. Currently they are very interested in memoirs and biographies and looking more for practical 'home-and-garden' type books, knowhow and self-help literature. Their lifestyle is domestic and practical. They live mostly in rural areas, small towns or villages. Their main sources of information and entertainment are the national TV and radio channels, local newspapers and journals of general interest. Since half of this group lives in poverty, the local library plays a very important role in their cultural and social life. They can borrow books and journals from the library, but also get access to a computer if they need e-services.

Type D: New moderate hobby- and entertainment-oriented reader (23\%). Like the previous type, this one is comprised mostly of readers from rural areas and smaller towns, but its gender and age structure is quite the opposite of type $C$ : younger and middle-aged men dominate (60\% are between 20 and 44$)$. These men do not like to read fiction $(71 \%$ do not read fiction or only occasionally read really exciting thrillers or science fiction). At the bookstore or the library, they would look for practical technical books (about cars, bikes, computers etc.), or books on business or sports. Only $13 \%$ of this type has read more than five books during the past 12 months; $69 \%$ have read one or two books or none at all; $40 \%$ have less than 50 books at home. Nevertheless, one third of them feel they belong to the middle class and 38\% to even higher strata of Estonian society. Twelve percent have their own small business; $72 \%$ have personal laptops and 78\% watch YouTube at least once a week. Members of this type are not interested in political participation or civic activities.

Type E: New hedonistic Internet-oriented non-reader (11\%). Although they are the youngest group (69\% are under 30$)$, it is the most self-confident: $50 \%$ classify themselves as members of the higher strata of society. In contrast to the multi-active type A, which is also comprised mostly of members of the young generation, type E could be labelled as the 'new non-readers'. They are not interested in reading books, besides those on computers, and maybe also some thrillers or fantasy books. They spend most of their time in a virtual reality, where they are skilled at all kinds of Internet usage. They are most active in using the Internet for creative self-expression. In the cultural field, their favourites are films and music, which are also most often consumed via the Internet. 


\section{Representation of the reading-related lifestyles in the different social groups}

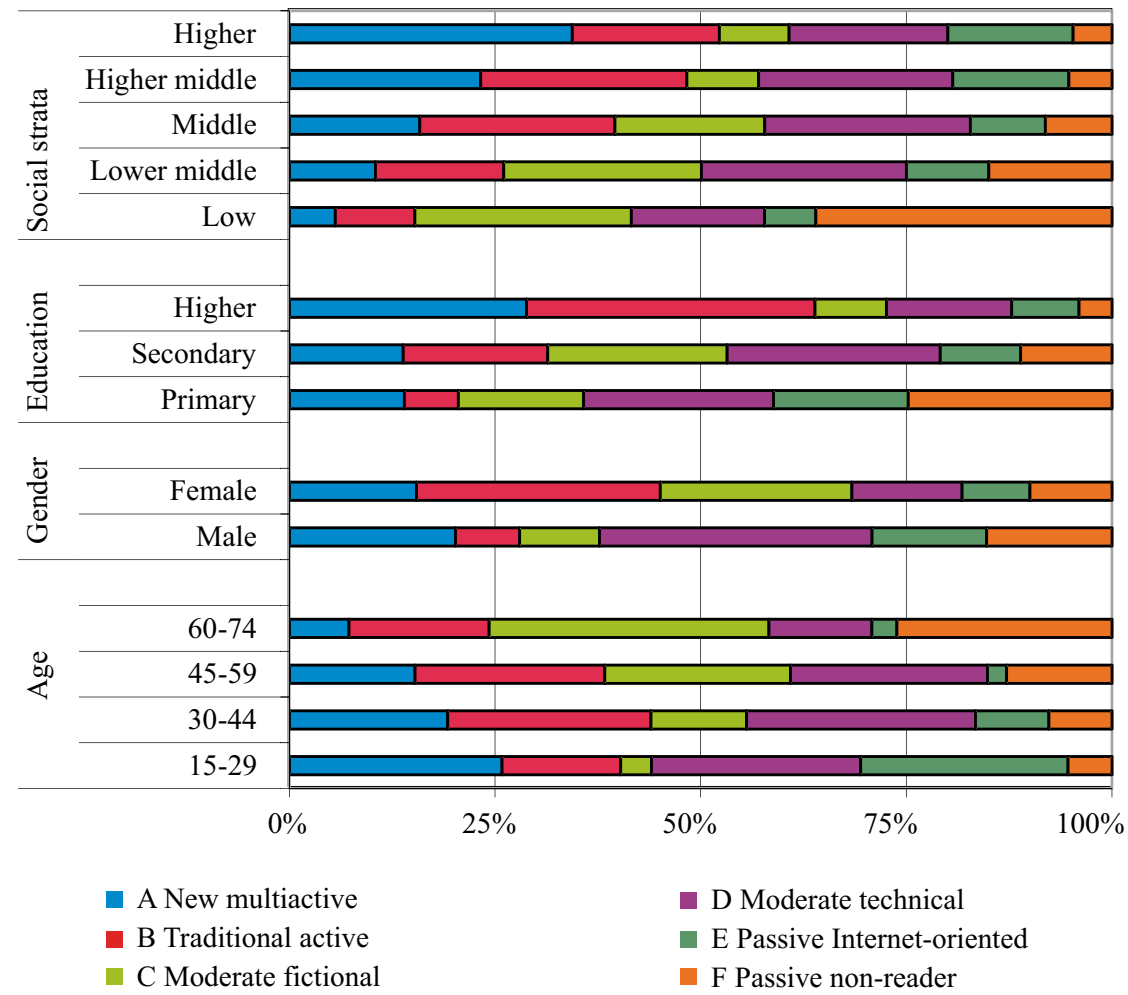

Figure 8. Representation of the reading-related lifestyles in the different social groups

However, this group is also most interested in reading e-books. However, the question is would young people who have no experience and interest in reading 'real' quality books suddenly be interested in reading e-books with a more demanding literary form or sophisticated content?

Type E: Traditional passive non-reader (12\%). This type is characterized by a lack of interest in reading and very passive domestic lifestyles. Watching TV and listening to the radio are their preferred cultural activities. This very passive lifestyle is partly caused by structural factors, such as old age, a low level of education and rural residence. But, since this type also includes a portion of quite young and even highly educated respondents, we also have to look for other possible reasons for the low level of participation in culture and social life. A possible reason for their almost total withdrawal from an active social 
life could be related to the miserable level of their material welfare: $68 \%$ are living in extreme poverty, and do not have money for the most elementary needs. Accordingly, we can characterise this type as whole as socially excluded people.

Comparing the representation of the reading related to lifestyles in the various social groups (Figure 8 and Appendix 5), some interesting trends should be mentioned.

a) The widespread belief in the total decline of reading among the youth is not supported by our data: the youngest age group is quite contradictory, and divided almost equally between three types: multi-active readers, moderate technical readers and Internet-focused non-readers.

b) The effect of the strong gender (female) bias in higher education supports an active humanitarian-type of cultural participation, dominated by traditional forms of cultural consumption, particularly literary reading.

c) Looking at the links between stratification and reading, we should mention that the middle strata of Estonian society are characterised by quite a moderate interest in reading quality literature or more sophisticated non-fiction, preferring books with practical and instructive content or with educating and entertaining content. The lowest social position is more often associated with a passive and socially excluded lifestyle (36\%), but still $52 \%$ in this stratum are active or moderate readers of fiction.

\section{Comparison between the structures of reading-related lifestyles in 1990 and 2011}

In order to identify the changes in the structure of reading in Estonia after the collapse of Soviet system, we can use the sociological data archive of our university, where the database of the national survey conducted by us in February 1990 is preserved in SPSS format. This old questionnaire contained a similar range of questions about pastime practices and reading preferences. The list of activities as well the list of the book genres were basically quite similar to those we used in 2011. There were also questions concerning book consumption and the reading of fictional or non-fictional literature. The nature of the questions and usage of scales was not exactly the same, but still quite similar to the indicators used in the 2011 survey. This similarity enabled to now apply the same kind of factor analysis and K-means cluster analysis to the old data, which has produced comparable structures of reading-related lifestyle components and book preferences for the data from 1990, as we had for 2011 (see Appendix 6). The six clusters were described using the same categories that were used above (the level of cultural participation and character of pastime activities, selectivity, thematic preferences, educational and economic resources, and gendered and generational features of cultural participation). The results of the cluster analysis are shown in Appendix 6. 
It is quite astonishing that, despite the dramatic decrease in the quantities of book consumption in Estonia (see Peeter Vihalemm's article in this publication), the structure of the reading-related lifestyles revealed by the cluster analysis had preserved some similar features through the past two decades.

The six clusters for 1990 were the following:
A. Active family-and media-oriented omnivore (18\%)
B. Multi-active socially oriented humanitarian reader $(8 \%)$
C. Selective non-humanitarian non-fiction reader (15\%)
D. Moderate family and media-oriented fiction reader $(20 \%)$
E. Passive home-centred fiction reader $(12 \%)$
F. Passive media-oriented non-reader (27\%)

This structure is visualised on Figure 9. By comparing this with the contemporary landscape of reading-related lifestyles that is described above, we discovered quite a similar gendered structure, with the fiction- and family-oriented, female-dominated 'home reading' types A, D and E comprising 50\%, and maledominated practical/ technical type $\mathrm{C}$ only $15 \%$. The share of passive media consumers without any interest in books, which is currently $23 \%$ and comprised of the two polarized types $\mathrm{E}$ and $\mathrm{F}$, made up of young new-media users and older traditional media users respectively, was even larger twenty years ago (27\%).

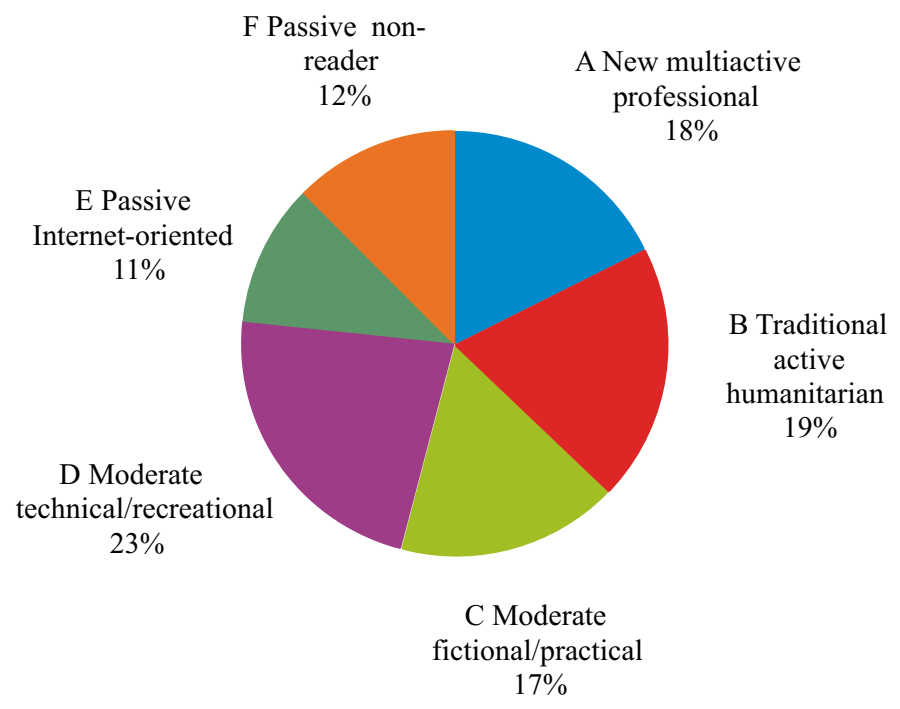

Figure 9. The share of the reading related lifestyles among the respondents (ethnic Estonians, age 15-74), 2011 


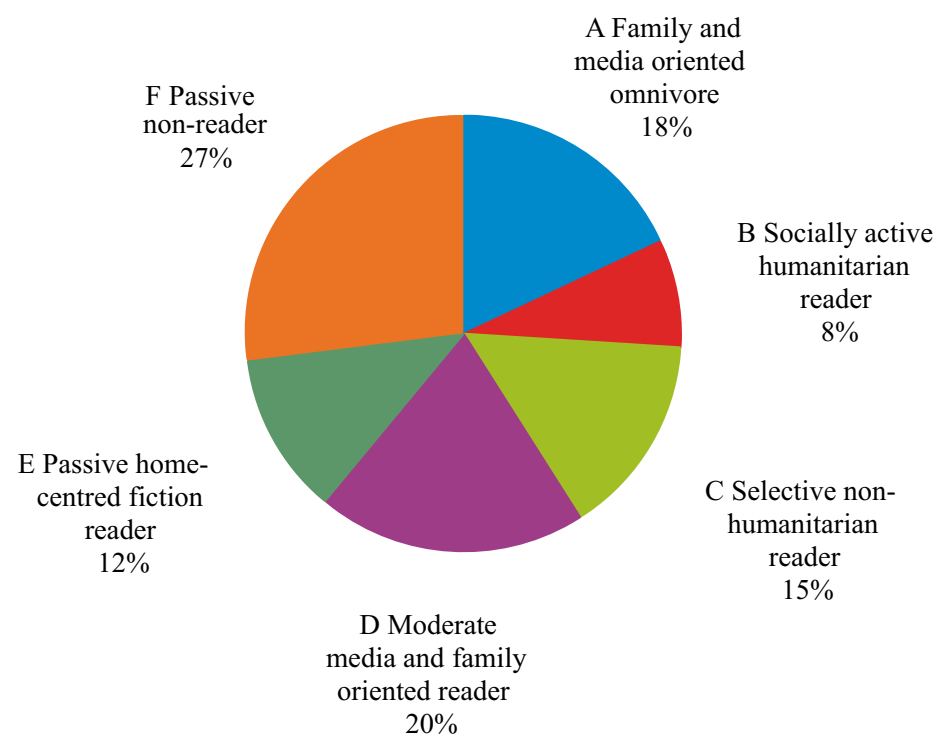

Figure 10. The share of the reading related lifestyles among the respondents, 1990

The most substantial difference between the two structures of reading-related lifestyles is caused by the emerging new E-generation. Specifically, in 1990, the 'youngish' type B was very small (8\%) and included boys and girls interested in poetry, the arts and music and spending their time in cafeterias and clubs, or watching movies and going to the theatre and concerts. In 2011, the youngest contemporary Internet-oriented type E seems to have replaced this outward and active humanitarian youngish type B from 1990. Contemporary type E also absorbs some of the adolescents who, in the Soviet system, were classified as belonging to the 'passive' media-centred non-reading type F, because they were not interested in the official culture and compulsory books, but were seeking access to alternative media (Finnish TV and underground copies of MTV music).

With the emergence of the multi-active non-fiction male-oriented type A in 2011, the gender axis of the contemporary structure seems more balanced compared to 1990, including not one, but two male-oriented types - A and D. Type $\mathrm{A}$ is quite similar to the professionally active type $\mathrm{C}$ from 1990; and the other, moderate technical/ practical readers type D is a new one and has obviously emerged because of the greater supply of the books about cars, computers, modern home repair technologies etc. 


\section{Conclusions}

1. The hierarchical patterns of reading, as well as the gender, age and status divides in Estonian reading culture are still clearly visible

2. Young readers cannot be viewed as a homogeneous group, but are polarised by their relationships with new media, and the realm of books.

3. Despite the overall post-1990s decline in the average amount of reading in Estonian society, the structure of the reading-related lifestyles has not radically changed, but had become more diverse and gender-balanced.

4. New types of reading-related lifestyles are emerging due to the greater availability and variety of non-fiction, especially books that are more oriented toward 'male interests' (technical/recreational reading type) and, on the other hand, due to the active use of social and multimedia channels by those who do not like to read.

\section{Acknowledgements}

The research was supported by grants of Estonian Science Foundation (8329) and Estonian Research Council (IUT20-38).

\section{References}

Allaste, A.-A. (Ed.) (2013), Back in the West: Changing Lifestyles in Transforming Societies. Frankfurt am Main: Peter Lang.

Bennett, T., Savage, M., Silva, E., Warde, A., Gayo-Gal, M. \& Wright, D. (2009). Culture, Class, Distinction. London \& New York: Routledge.

Bourdieu, P. (1984/2010). Distinction: A Social Critique of the Judgement of Taste. London \& New York: Routledge.

Bourdieu, P. (1993). The Field of Cultural Production. Cambridge: Polity.

Dahrendorf, R. (1990). Reflections on the Revolution in Europe. London: Chatto \& Windus

Di Maggio, P. (1987). Classification in Art. American Sociological Review, 52(4), 440-455.

Gans, H. (1999). Popular Culture and High Culture: An Analysis and Evaluation of Taste. New York: Basic Books.

Giddens, A. (1991). Modernity and Self Identity: Self and Society in the Late Modern Age. Cambridge: Polity.

Griswold, W., McDonnell, T. \& Wright, N. (2005). Reading and the Reading Class in the Twenty-First Century. Annual Review of Sociology, 31, 127-141.

Heidmets, M., Kangro, A., Ruus, V., Matulionis, A., Loogma, K. \& Zilinskaite, V. (2011). Education. In M. Lauristin (Ed.), Estonian Human Development Report 2010/2011. Baltic Way(s) of Human Development: Twenty Years On. Tallinn: Eesti Koostöö Kogu.

Kalmus, V., Masso, A, \& Lauristin, M. (2013). Preferences in media use and perception of inter-generational differences among age groups in Estonia: A cultural approach to media generations. Northern Lights: Film \& Media Studies Yearbook, 11(1), $15-34$. 
Lash, S. (1994). Reflexivity and its Doubles. In U. Beck, A. Giddens and S. Lash. Reflexive Modernization. Cambridge and Oxford: Polity Press.

Lauristin, M. (2013). New Media and Changes in the Forms of Cultural Transmission: Estonian Experience. In Runnel, P., Pruulmann-Vengerfeldt, P., Viires, P. \& Laak, M. (Eds.), The Digital Turn. Users' Practices and Cultural Transformations. Frankfurt am Main: Peter Lang.

Lõhmus, M., Lauristin, M. \& Salupere, R. (2004). Inimesed kultuuriväljal: aktiivsus ja eelistused (People on cultural field: activities and prederences). In V. Kalmus, M. Lauristin \& P. Pruulmann-Vengerfeldt (Eds.), Eesti elavik 21.sajandi algul: ülevaade uurimuse Mina.Maailm.Meedia tulemustest. Tartu: Tartu Ülikooli Kirjastus.

Lõhmus, M., Lauristin, M. \& Siirman, E. (2010). The Patterns of Cultural Attitudes and Preferences in Estonia. In M. Lauristin \& P.Vihalemm (Eds.), Estonia's Transition to the EU: Twenty Years On. London \& New York: Routledge.

Offe, C. (1996). Varieties of Transition. Cambridge: Polity Press.

Vihalemm, P., Lauristin, M. \& Kõuts, R. (2012). Trends in Estonian media landscape in 2000-2012. Media Transformations, 6, 12-63.

Warde, A. (Ed.) (2011). Cultural Consumption, Classification and Power. London \& New York: Routledge. 


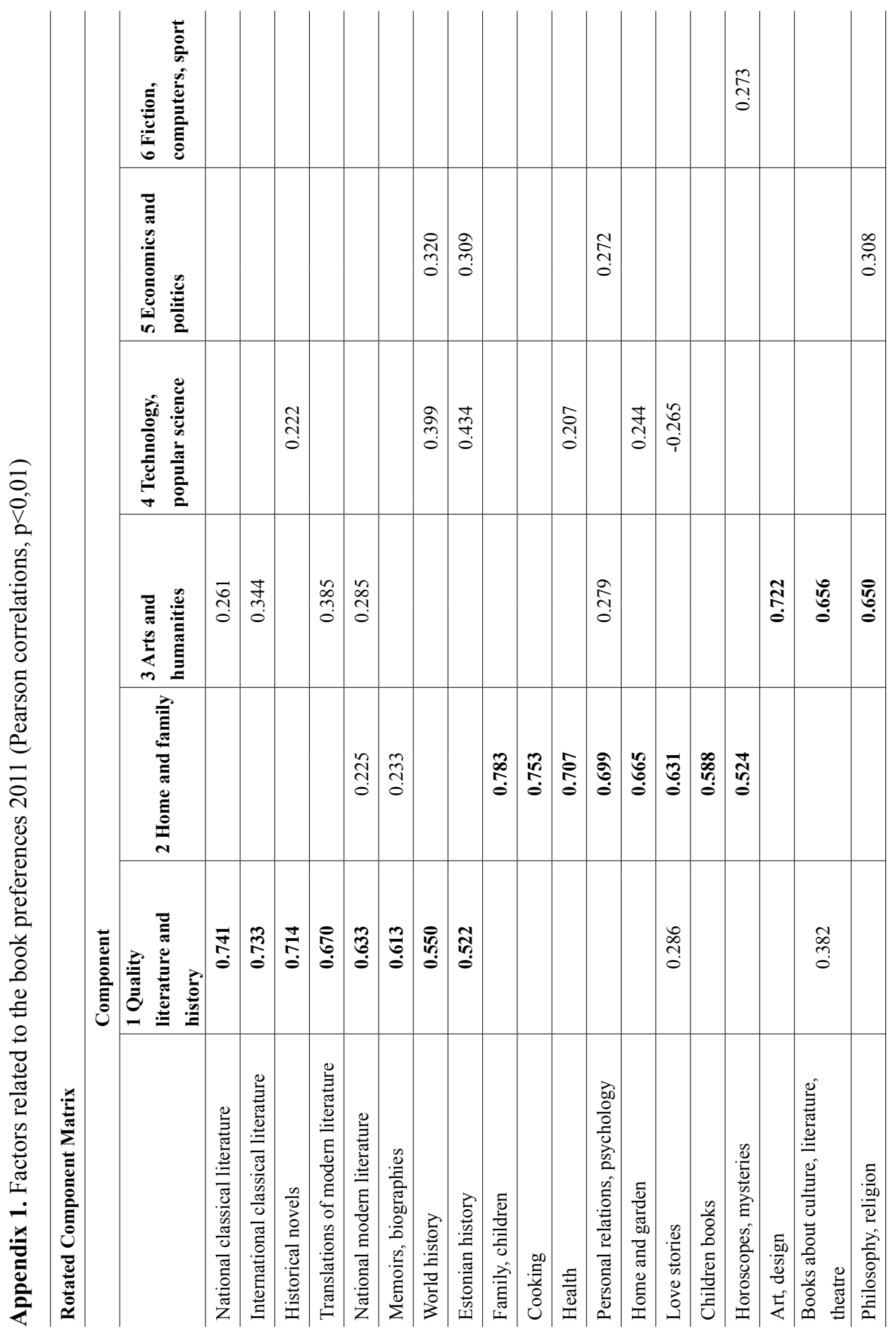




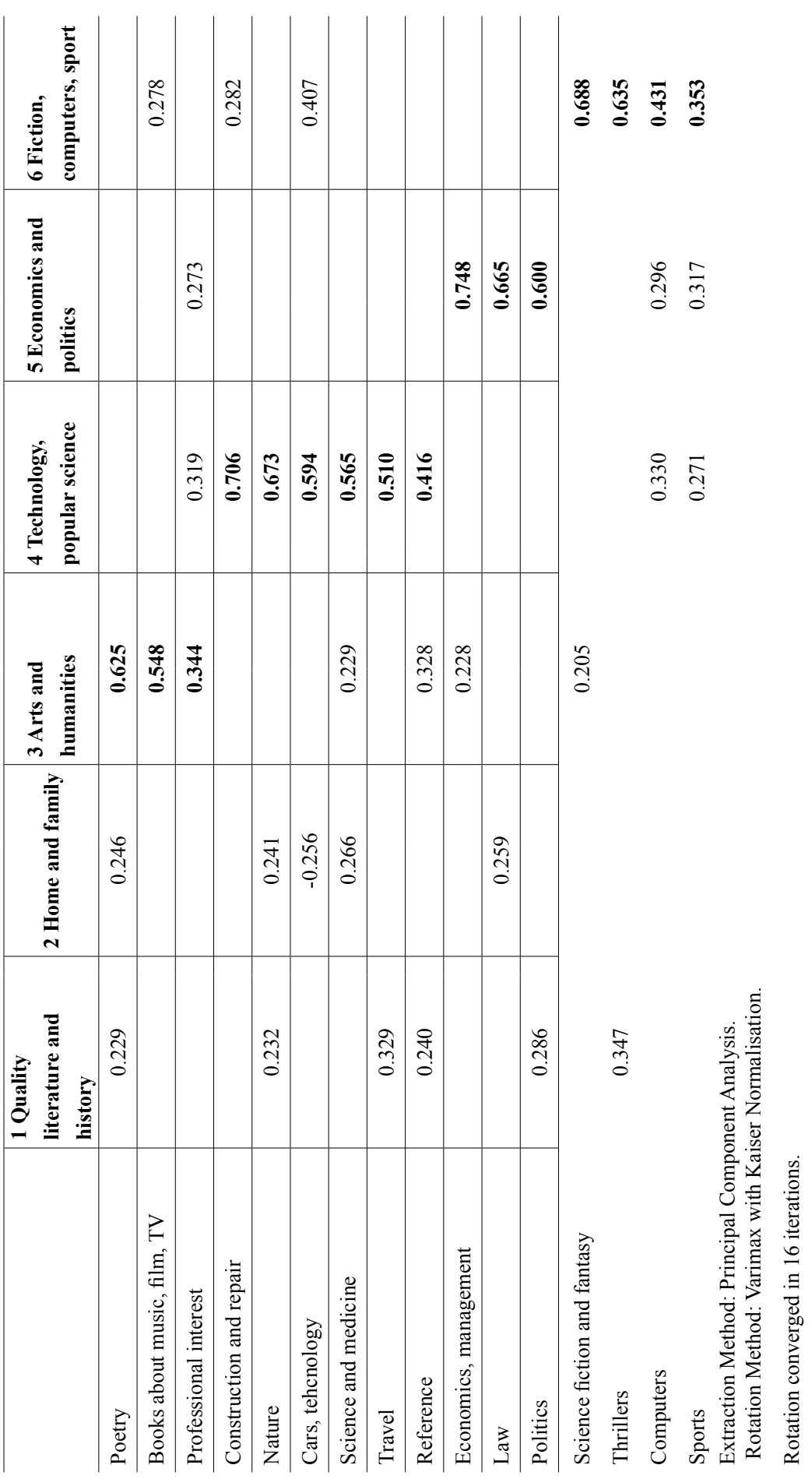




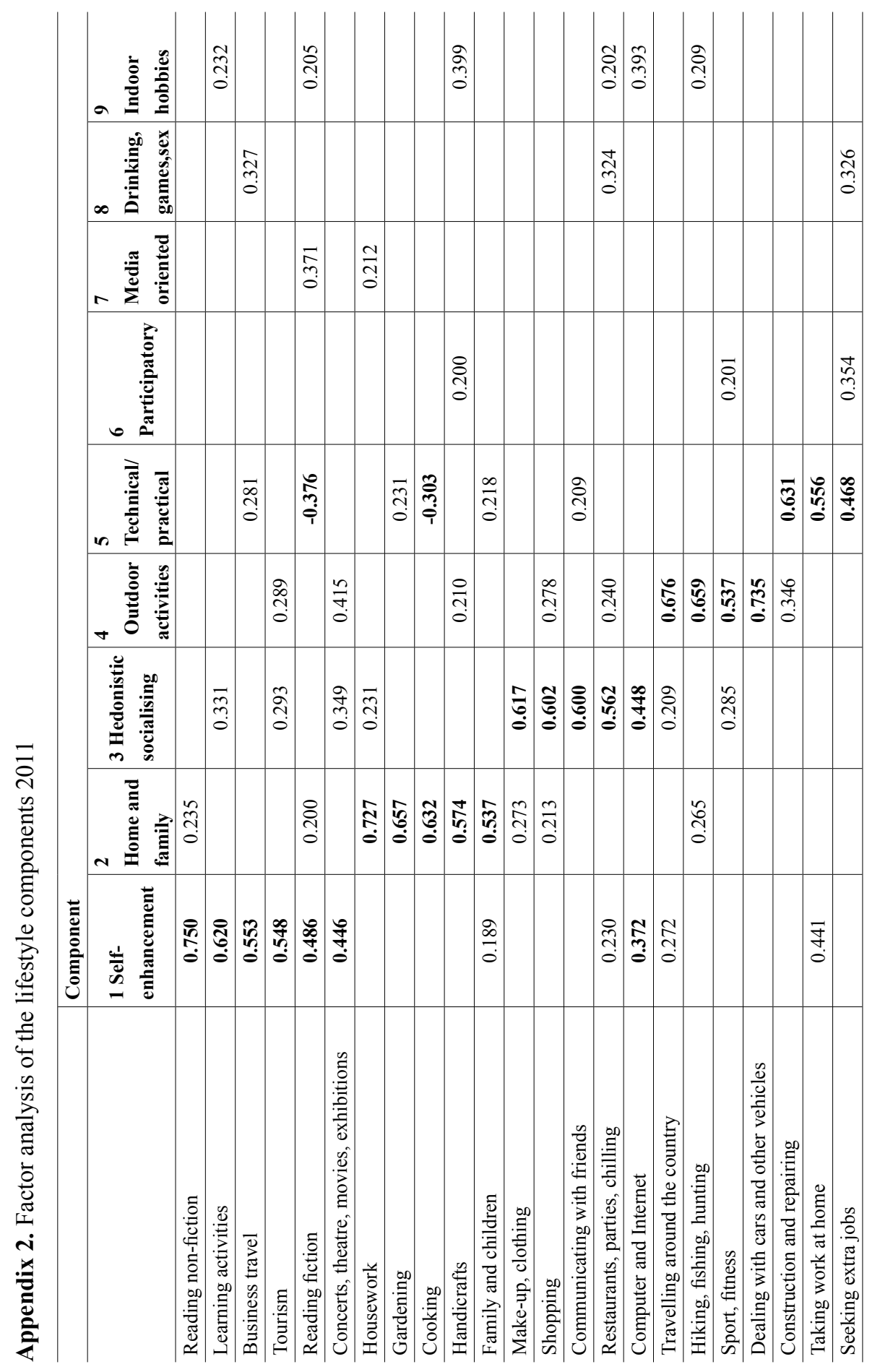




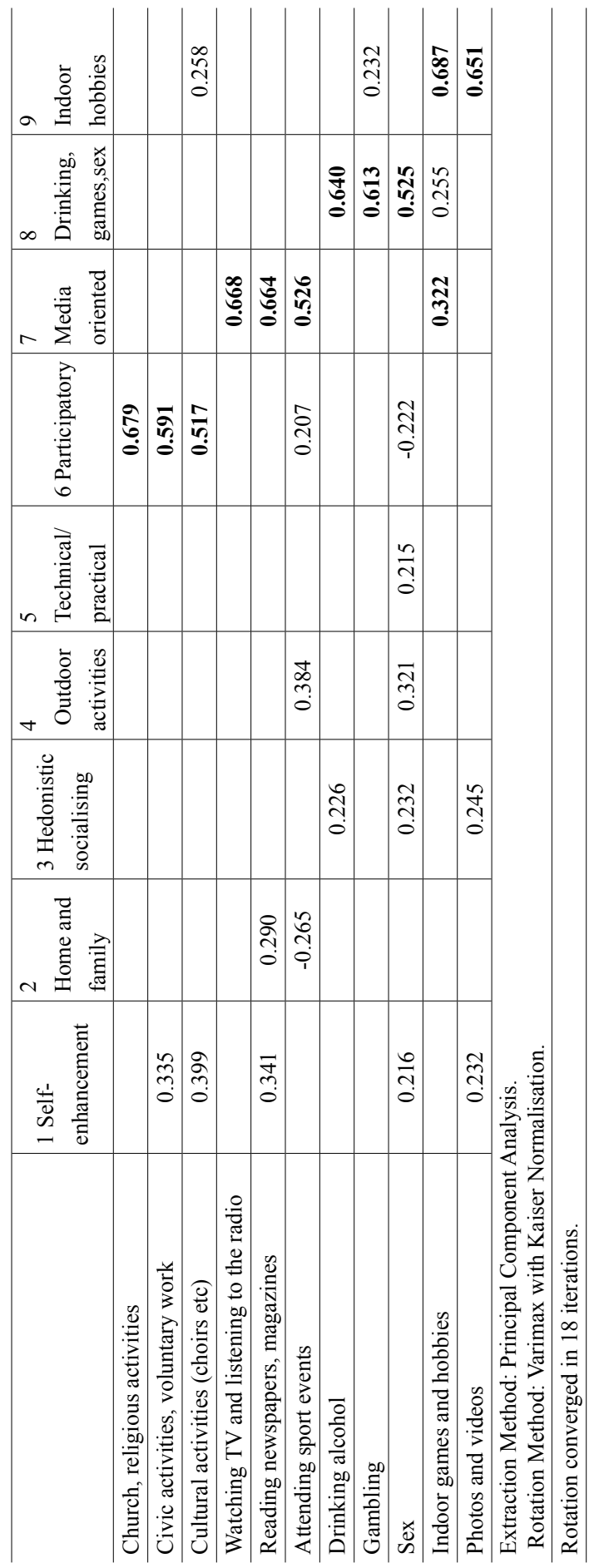




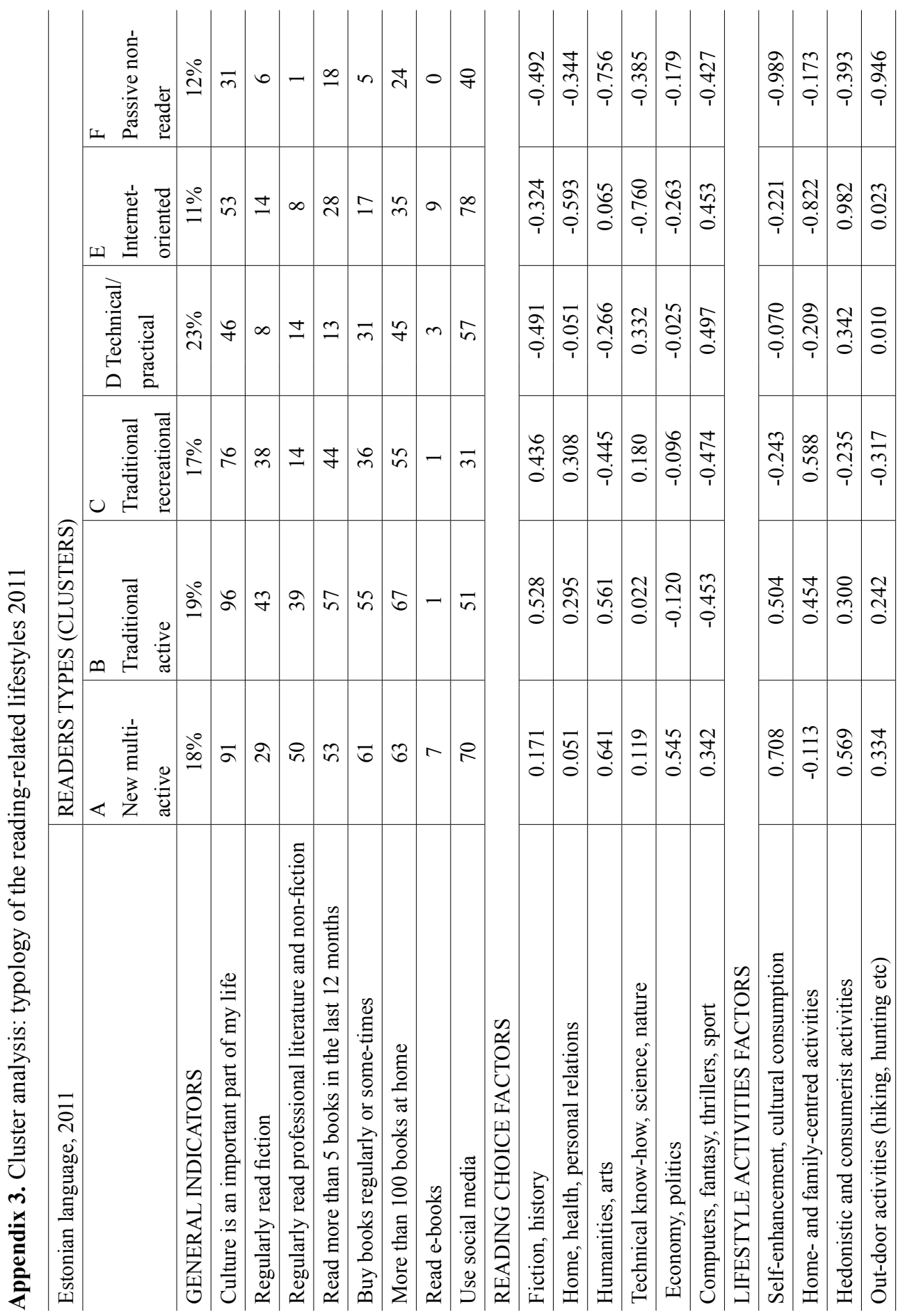




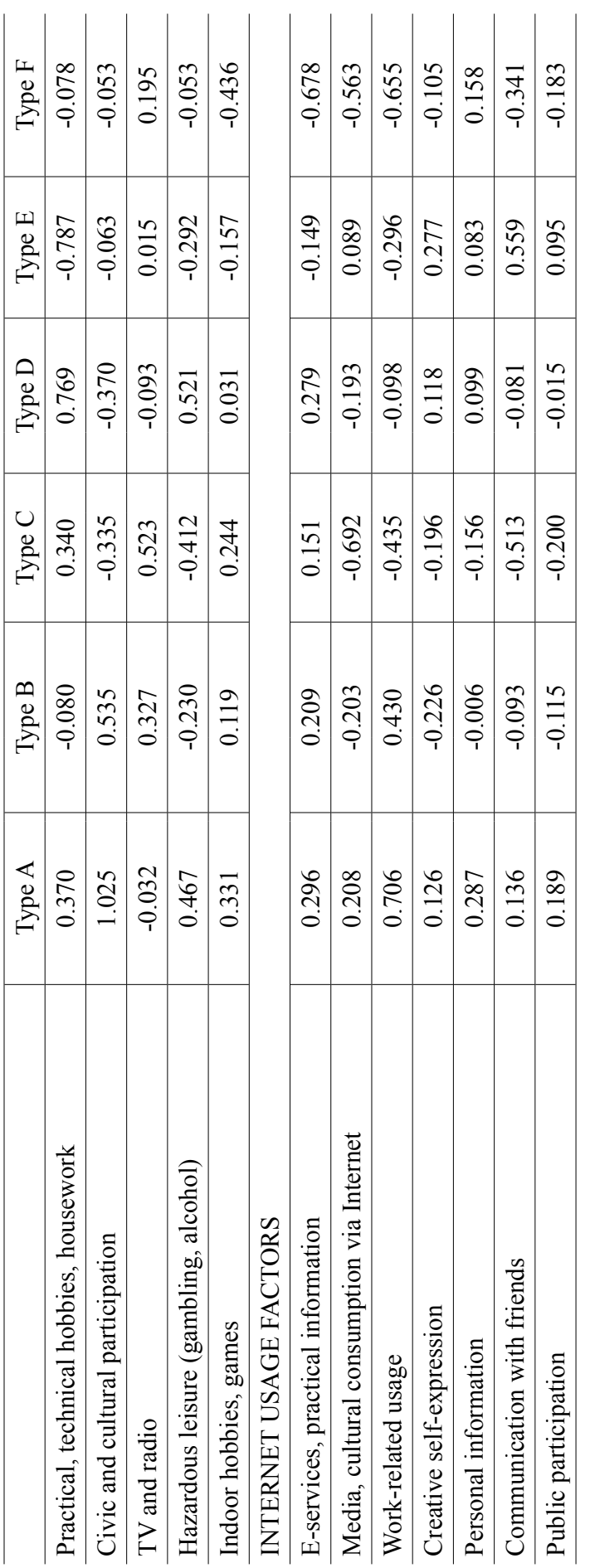




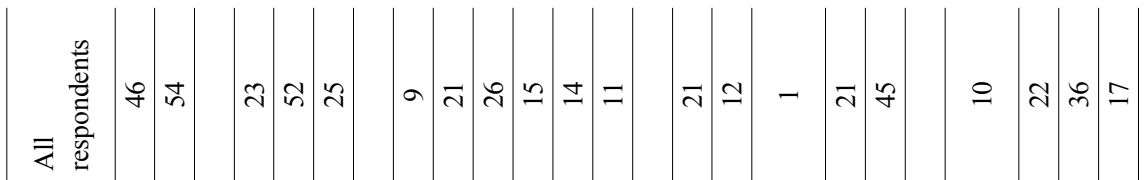

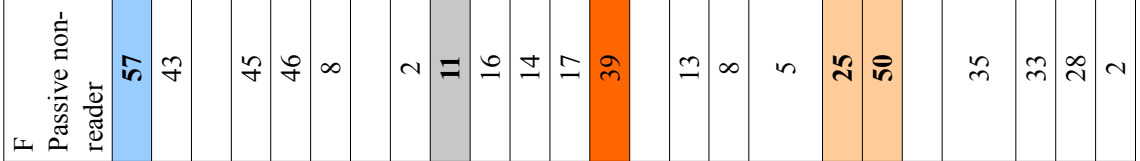
离 莺 띠 븡

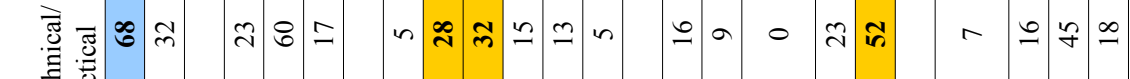

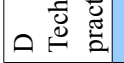

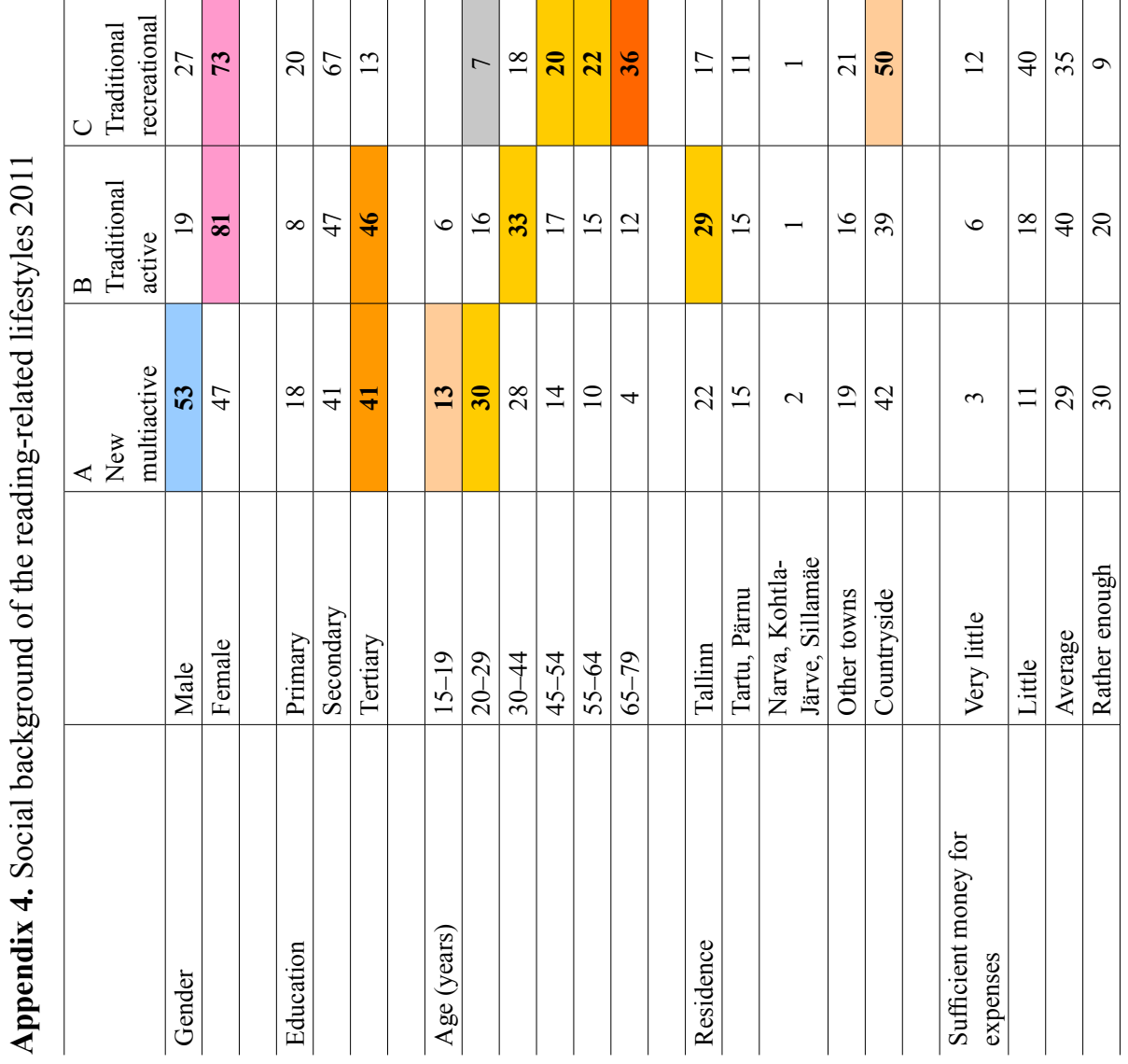




\begin{tabular}{|c|c|c|c|c|c|c|}
\hline 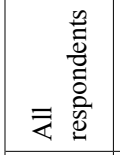 & $\simeq$ & ঃ & ㄴ & $\because 0$ & $\therefore \stackrel{\sim}{\sim}$ & $\tilde{\sim}$ \\
\hline 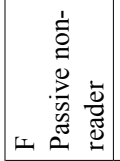 & $N$ & ล & - & $\stackrel{2}{*}$ & $\mathrm{~S} \stackrel{\infty}{=}$ & 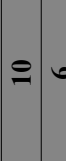 \\
\hline 巧 & aิ & 2 & $\begin{array}{lll} & 0 & 0\end{array}$ & $a$ & 욕 & हి \\
\hline 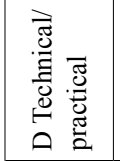 & $\Xi$ & $\infty$ & $\simeq=$ & $=\bar{\gamma}$ & $\overrightarrow{\mathrm{v}} \bar{m}$ & $\stackrel{\sim}{\sim} \Omega$ \\
\hline 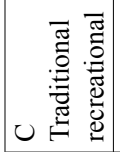 & $\sigma$ & 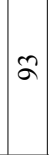 & $r$ & $\tilde{\approx}$ & v & $\approx r$ \\
\hline ص & $\because$ & $\bar{a}$ & $a r$ & -12 & $\therefore \mid \vec{m}$ & లి త్ \\
\hline « & $\stackrel{\infty}{\sim}$ & $\infty$ & নి & $n=$ & $=\dddot{\sim}$ & ల్లి: \\
\hline & 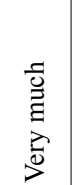 & $\stackrel{8}{z}$ & 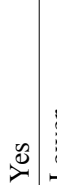 & 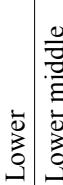 & 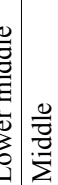 & 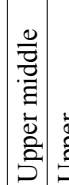 \\
\hline & 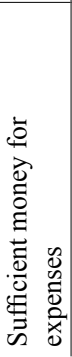 & 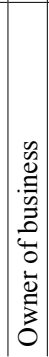 & & 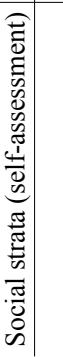 & & \\
\hline
\end{tabular}




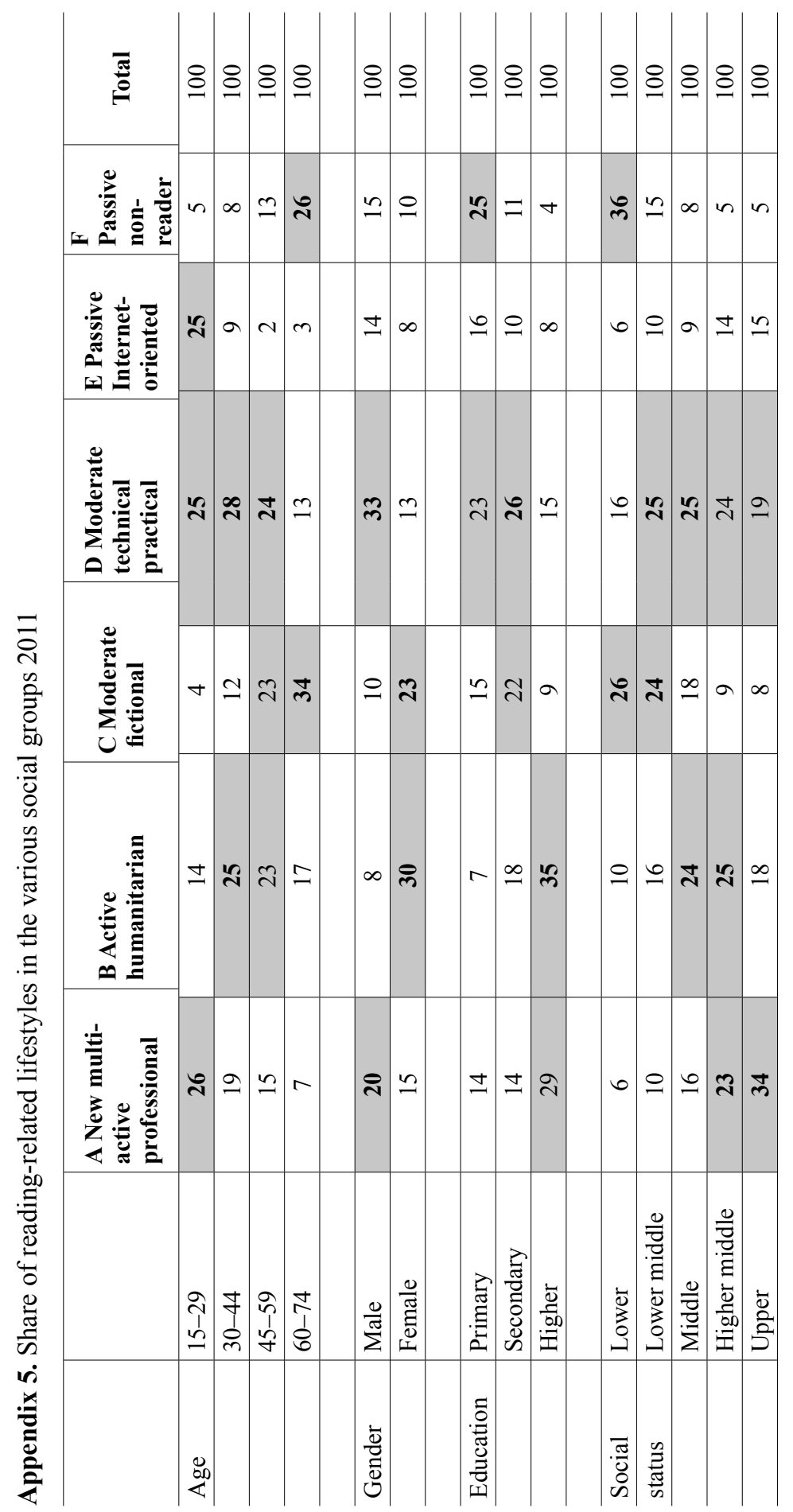


इ

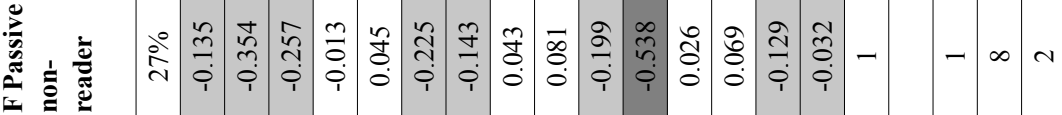

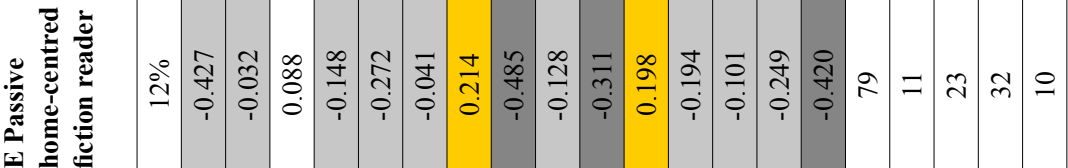


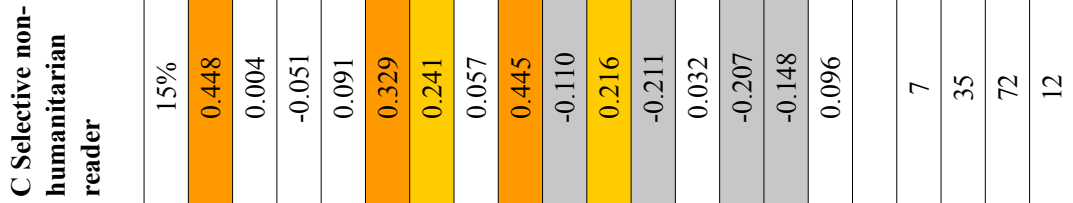

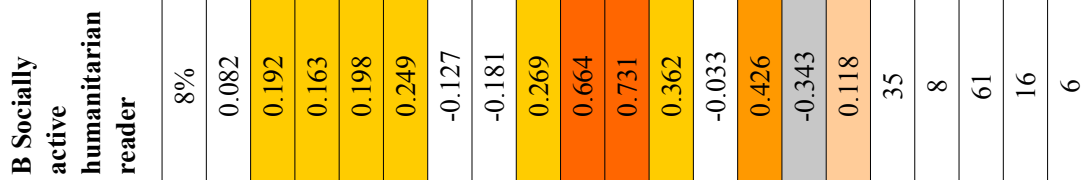

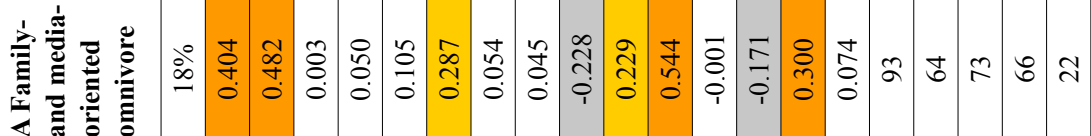

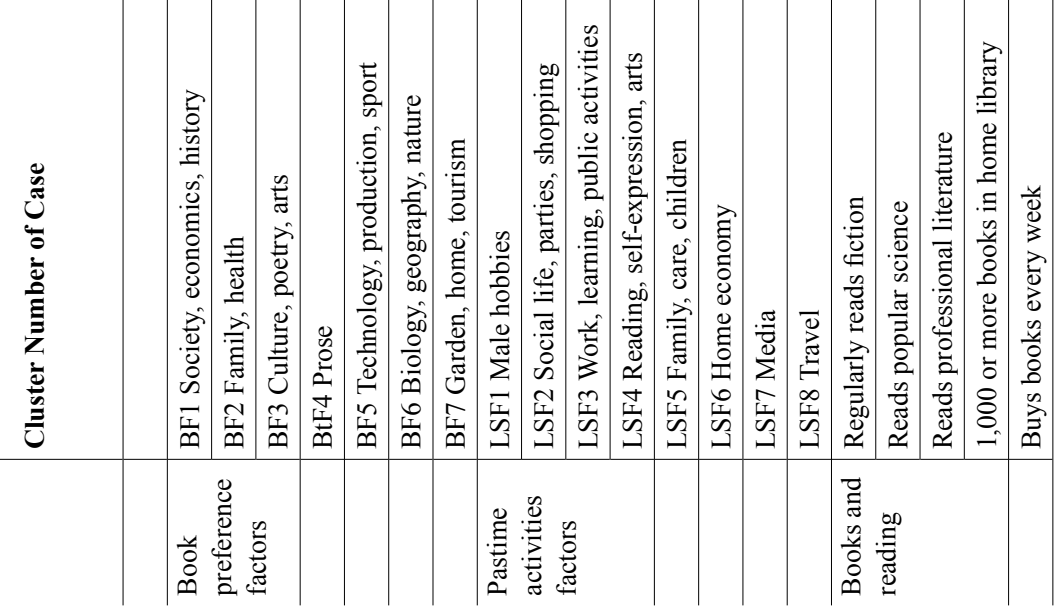




\begin{tabular}{|c|c|c|c|c|c|c|c|c|c|c|c|}
\hline 嵒 & & in & f & $\infty$ & $\sigma:$ & ¿ & $\vec{v} \stackrel{\infty}{\sim}$ & $\cong r$ & $\infty$ & $=$ & $\infty \subseteq$ \\
\hline 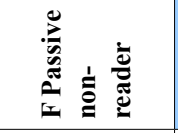 & $\stackrel{\infty}{n}$ & f & $\stackrel{\infty}{q}$ & సి & $\infty \bar{\sim}$ & $\approx 9$ & $\Rightarrow=$ & $=n$ & in \pm & $\because$ & $\wedge r$ \\
\hline 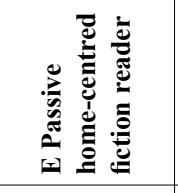 & $\vec{m}$ & 8 & in & ते & + ते & $\bar{\sim} \approx$ & $y=$ & $a=$ & if & 9 & $m$ \\
\hline 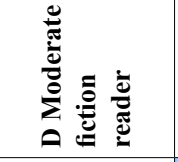 & $\stackrel{\infty}{\infty}$ & S) & $\approx n$ & $=$ & $m=$ & $\stackrel{\infty}{\sim} \approx$ & $0=$ & $=0$ & q & 인 & $\infty \quad m$ \\
\hline 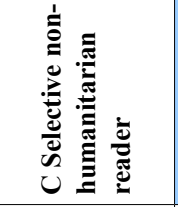 & $\approx$ & $\approx 7$ & if & $\infty$ & $\therefore \because$ & 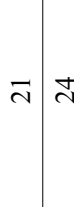 & $\mathfrak{v} \simeq$ & $O$ in & in & 2 & $\sigma \pm$ \\
\hline 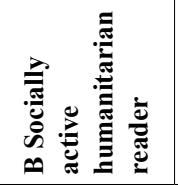 & f & $\tilde{n} \approx$ & if & $\approx$ & $\bar{N}$ & $\div$ 이 & $\infty$ & in $m$ & ते & \pm & $-\approx$ \\
\hline 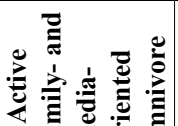 & $\stackrel{\infty}{+}$ & $\therefore \overline{7}$ & $\infty_{n}^{\infty}$ & $F$ & $=\cong$ & $\because \approx$ & S: & $\simeq \sigma$ & $\vec{\sim} \approx \widetilde{m}$ & $\simeq$ & $\simeq \pm$ \\
\hline & $\sum^{\frac{\pi}{2}}$ & II & 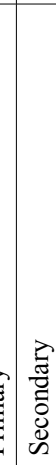 & 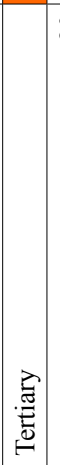 & 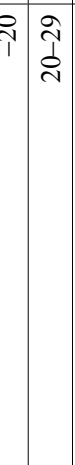 & 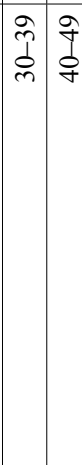 & 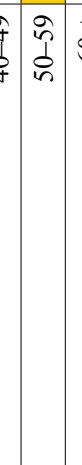 & 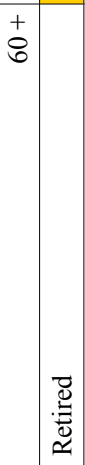 & 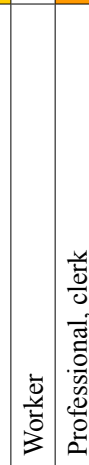 & 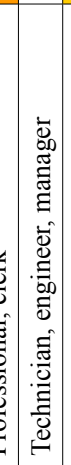 & 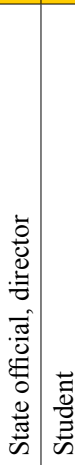 \\
\hline ळू & & & & & 然 & & & 总 & & & \\
\hline
\end{tabular}




\title{
The reader in a clash of cultures: The experience in Eastern Latvia (Latgale cultural region) 2009-2011
}

\author{
Mara Grudule, Ojars Lams
}

\section{Introduction}

One of the major Latvian daily newspapers is launching its subscription campaign this year with the slogan "You are what you read", but in turn we should mention Nikolai Pirogov's dictum "Books - that is the society. Tell me what you read, and I will tell you who you are". It has long established itself as a locus communis regarding the question of the importance of reading. In Pirogov's observation books - that is the society provides a certain clarification regarding the preoccupation of the social sciences with the study of reading processes. Nevertheless, reading is explicitly characteristic of the humanities. Humans are at the centre of the reading process. As Martyn Lyons states, "Readers are not passive or docile; they make texts their own, by improvising personal meanings and making unexpected textual connections" (Lyons 2010: 4). Each individual's reading path is unique. This conclusion is quite comforting, because it attests to the worth of humans. At the same time, it can provoke fear, regarding the possibility of comprehending and investigating this variety of individualities in general and noticing anything relevant to the society. For the empirical material to be more comprehensible and better suited for closer examination, it is useful to maintain a sociological perspective, acknowledging that individual occurrences and experiences are incorporated in a definite shell, which is no less important, and which, to a great extent, defines the value of the individual core.

The French scholar Pierre Bourdieu offers two points of reference for a sociological perspective - cultural capital and economical capital (Bourdieu 1979). The circulation and utilisation of books involves definite codes, which classify readers into social groups. The extra-literary aspects are especially 
significant - education, role models, age, income, occupation etc. In our studies of the reading process we have respected Bourdieu's notion of cultural capital, which includes education and prior experience, and we have applied them to the categories of literary theory, e. g., genre, style, literary movements, poetics of the text and the like, with the utmost clarity and precision to provide an understandable definition.

Although nowadays, reading is an individual, and even intimate, process (reading tends to be dissociative and protective of one's space) it would still be useful to keep in mind that reading was originally vocal - an activity to establish and maintain a collective spirit. This ancient and atavistic form has not become extinct and is not about to, thereby repeatedly not letting society forget the importance of the reading process. In the various regions of Latvia, though mostly in the major cities, one can find quite a number of different kinds of literary clubs and associations, which maintain the social significance of reading. However, in search of new members they are willingly cooperating with schools, libraries and other institutions.

Museums should be mentioned as important centres of support for reading. The museum landscape in rural Latvia has changed during the years of independence - some of the smaller scale commemorative museums have ceased to exist for ideological and financial reasons, but mostly due to the restitution of property. However the empty spaces have been filled - new museums have been established. Exhibitions devoted to local history have been created by enthusiastic collectors; preserved clusters of ethnographic buildings have now been turned into museums; and small-scale commemorative exhibitions for the exceptional people of the region have been organised at the local schools and libraries. In the reading processes related to literary texts, significant importance is placed on the commemorative exhibitions for writers, regardless of whether they are devoted to authors of local importance, e.g. Latgallian poet Marija Andžāne (1909-1988) on the very periphery of Latvia, or to authors, one might say, of international calibre. For instance, in Galēni, one of Latvia's poorest municipalities, the local cultural heritage society has funded the establishment of a commemorative museum for the great Latvian philosopher and poet, Prof. Robert Mūks (1923-2006), who taught the history of religions for a long time at Iona College in New Rochelle, New York (USA). Or in Asūne, in one of the farthest corners of Latvia, a commemorative room has been established for translator and writer Konstantīns Raudive (1909-1974) a world-famous explorer of voices from the afterlife. These places provide a stimulating, reader-friendly atmosphere and define the unique characteristics of local reading practices. 


\section{About the study and its methodology}

The study is based on reading traditions from the perspective of sociology and literary studies, and was conducted by distributing questionnaires to readers of different societal and occupational groups. The questionnaire included the following:

(1) information about the respondent;

(2) evaluation of the respondent's reading practices - where, what and how the reading material is acquired and a description of the respondent's book collection;

(3) the respondent's attitude towards belles-lettres in the synchronic and diachronic dimensions, as well as their attitude towards particular representatives of literary activities - the evaluation of both acknowledged and locally notable ones;

(4) the final section of the questionnaire attempts to identify the respondent's attitude towards his/her own local cultural scene, including the literature.

This study was conducted by the academic staff of the Chair of the History of Latvian Literature and Literary Theory in the Faculty of Humanities at the University of Latvia over a period of ten years in the different regions of Latvia. Our goal was to study the reading culture of the places, where reading material is comparatively hard to acquire - where the places that sell or lend books (post offices, bookshops, libraries etc.) are faraway and often difficult to reach, where access to the Internet is limited, etc.

For three years the study (2009-2011) was conducted in three localities called Viḷāni, Preil̦i and Dagda in the Latgale region of Eastern Latvia. These are small centres surrounded by dispersed populations. A total of 389 inhabitants were queried.

Semi-structured in-depth interviews were employed to acquire the data. The respondents were asked to provide exact figures and to elaborate on their answers. During the interviews it was essential to establish a partnership between the interviewer and the respondent in order to clarify the issues relevant to the study together. Structurally the interviews tended more towards exactitude with relatively standardised features. Space was reserved for an open interview and additional commentaries, while also maintaining the general determined direction of the conversation.

A small group of literary studies students were involved in collecting the data. Before embarking on the fieldwork, the students were provided instructions about the theoretical questions, in order to ensure the highest quality of information gathering. This experience improved their skills and their knowhow in anthropology and sociology, thus the study was also educational for the students. 


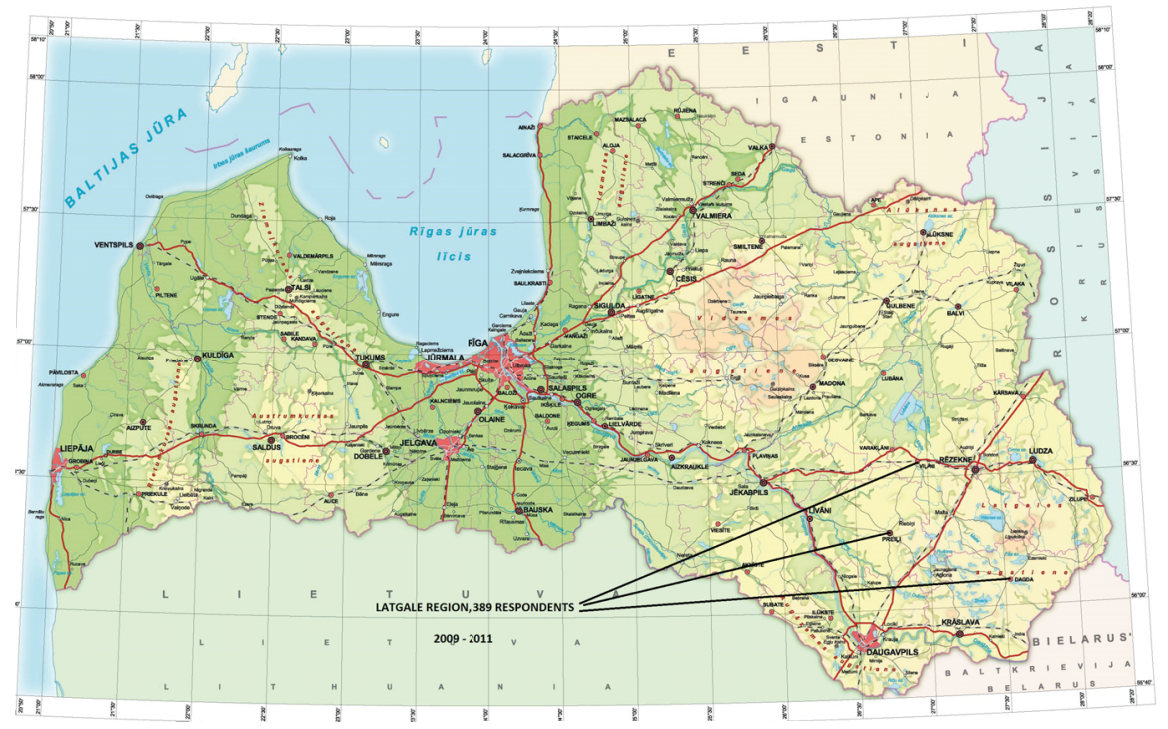

Figure 1. The map of Latvia indicating the three localities (Viḷāni, Preiḷi and Dagda) of Latgale where the survey was conducted

In the course of summarising the answers, unexpectedly, a rather fragmented view revealed itself, and, at times, the information was hard to convert from the quantitative into the qualitative.

\section{About Latgale}

Latgale is one of four historical districts of Latvia. For several centuries, the specific Latvian culture of Latgale developed in isolation from the other regions of Latvia. The native inhabitants use a specific language - Latgallian, which is also called the High Latvian dialect. In Latgale, about a half of local inhabitants still use the Latgallian language today. For a long time - from 1562 until 1772 Latgale was a province of Poland. This ensured the preservation and dominance of Catholic traditions as opposed to other two regions of Latvia - Vidzeme and Kurzeme, which were affected by the Reformation. During the period of the Russian Empire, the isolation continued and Latgale was incorporated into the Vitebsk Governorate. In the mid-19th century the development of book and periodical publishing was of great importance to the Latvians, since it advanced their national aspirations and created of a sense of unity. However, the newspapers that agitated and moved the peasants in Vidzeme and Kurzeme, didn't reach Latgale. And even if they did, the Latgallians in Latgale couldn't read them, because the Jesuits in Eastern Latvia had used a different writing tradition - the Latin alphabet instead of the Gothic script used in the rest of Latvia. In 1910 one of the leaders of national awakening in Latgale, journalist and poet Kemps stated: 
"as the written language comes with its influence closer and closer to the borders of Latgale, it becomes much more difficult for it to succeed in fighting the dialectal peculiarities, until, when at the heart of Latgale, it can not do anything at all: the folks just don't read Baltic writings whether dressed in Gothic or Latin letters" (Kemps 1910: 49).

The state of the Latgallian language is still quite stable in this region. The differences between the written and spoken language became an original feature in the emancipation process of the region, which, in a way, is experiencing a contemporary renaissance. The otherness of the region is created by its historical ethnic communities - the Old Believers, Poles and Jews. During the Soviet period the major cities in Latgale were subjected to brutal Russification.

\section{Private book collections and attitude towards reading and books}

Anton Chekhov has said that a house without books is like a body without a soul. The results of this study show that people living in the rural regions of Latvia cling to this idea. When furnishing their homes, having a decent book collection is a must for most inhabitants of Latgale. Almost all of the respondents said that they have about 100 to 200 books in their collections. Only in very poor households, which suffered under less fortunate social conditions, were there no books. Derelicts were not included in the field research as it was not possible to have a conversation about reading with them.

In regard to the private book collections, it was observed that a rupture occurred dictated by the change in regimes. Most of the respondents said that their book collections were acquired in Soviet times when books were considerably cheaper and, in those times of scarcity, popular books were especially valuable. The bookshelves of the country folk mainly contain the remnants of popular Soviet book series - Ievērojamu cilvēku dzìve (Lives of Remarkable People), Stāsti par dabu (Stories about Nature), Horizonts (Horizon), Piedzīvojumi un zinātniskā fantastika (Adventures and Scientific Fantasies), etc. - along with a volume or two of the classics of Latvian literature. The books published during the Soviet era keep alive the memories of the exclusive role played by books in the deformed Soviet system. Ksannas Mazhurina's statement speaks precisely to this issue:

"During the Soviet era, culture was the one and only way to demonstrate one's place in society. One could not buy a factory or own a business, but one could try to collect a good home library, and thus demonstrate one's position in terms of connections and social position. Rare and deficit books on a bookshelf at that time were a clear symbol of individual status and success." (Mazhurina 2009: 
Another group of books encountered in the homes are the ones with practical applications - how to manage a household, run a farm, or garden. A regular interest in the latest books and in augmenting one's existing collection was a much rarer occurrence. In regard to book purchasing, a clear division can be observed between interest groups, which are defined by a special passion or interest or on a certain author or literary genre (the most popular crime fiction, as well as the hottest trends - Harry Potter and Twilight), on a specific subject matter (mostly history and biographies; but a small portion of the respondents emphasised an interest in their local region).

In general, book purchasing in Latgale did not seem to be an especially esteemed activity or seen as necessary. However, people do treat their books with consideration and respect and only 19 respondents, or $4.8 \%$, admitted to destroying books for ideological reasons. The bookshelves at home are seen as indicators of their surroundings, as signs of the owners' taste and sometimes their social status as well. However, for about one third of the respondents, the main source of reading material, private book collections and reading habits have only an indirect relationship. The main source of reading material, especially periodicals, is libraries - for example, $65 \%$ of the readers of one of the largest daily newspapers Diena" (The Day) read it at the library; about 25\% of the local readers of Latvijas Avize (Latvia's Newspaper), the most popular daily newspaper for rural inhabitants, read it at the library; and about $26 \%$ of the magazine readers go to the library to read them.

Generally, libraries are well frequented not only for the free Internet or computer access, but for the books as well. Sometimes there is a long waiting list for the most popular books.

\section{Contemporary literature and the rural reader}

The main trend observed among rural readers, regardless of financial position, age or education, is their isolation from the literary process as a means of development and change. This means that the names of the new literary works and authors that have become current topics during the last two decades in the literary and cultural milieu of the capital - a new generation, which is actively engaged in prose and poetry - is in fact completely unknown in the rural regions. The generation who has made a name for itself with innovation and original endeavours seems to be of no great interest to the rural inhabitants. About $0.8 \%$ of the respondents even said that they detest contemporary Latvian literature. The collected data proves that a small number of the respondents (percentage in brackets) have heard of or read works by such prose writers like Inga Ābele (0.4\%), Nora Ikstena $(0.4 \%)$, Gundega Repše $(0.3 \%)$, Pauls Bankovskis $(0.26 \%)$ or Jānis Einfelds $(0.08 \%)$, who are highly praised by the Latvian intelligentsia and literary critics and have even been translated into foreign languages. 
Only a small group of people - most of whom are local female teachers and library workers - show any interest in the latest events in Latvian literary process, And some of the respondents' answers show that this is due more to an obligation that they feel, and less because of their own interest. They also stressed that contemporary poetry is the hardest to accept and understand. Since most people in rural regions who work in culture-related fields are middle-aged or older women, their concept of poetry is still based on the prevailing trends of the 70's and 80's. At the same time, there are poets of local significance in every region, who are very well-known and popular. The category of eminent inhabitants of the region includes such people as "Madam Petrova, the neighbour, who writes poetry" which was one of the actual responses to the questionnaire.

\title{
Newspapers and magazines
}

Reading newspapers and magazines is a beloved pastime in the country. The local newspapers are the most read by far. Reading the main national newspapers is much less popular. In this regard, the respondent's education plays an essential role. None of the respondents with less than a secondary education read the main national newspapers.

Anda Rožukalne, the Latvian mass media scholar, points out that

\begin{abstract}
"magazines help people finding their way in the surrounding world; they tell you what the trends are in social developments; how opinions about politics are created and changed; where to travel, what is fashionable, how to care for your beauty, how to furnish your home etc. [...] in the analysis of audience habits it has been established that in the Western European countries about $70 \%$ of the population reads one or more magazines monthly, and in some countries this figure even reaches 95\% of the population" (Rožukalne 2011: 163, 218).
\end{abstract}

Our survey proves that weekly editions or magazines, including the supplements of the main newspapers, which can be purchased or subscribed to separately, are the most widely read.

"It can be said about the profile of magazine audience that, in general, it corresponds to the advertisers' wish to see the middle class as the consumers of their products - people from the age 15 to 45 , both urban and rural, with an average or above average income" (Rožukalne 2011: 219).

Rožukalne's statement (2011: 184), that the audience is created in the interests of the advertisers, and that the editors strive to please their interests, and the content of the magazines suffers as a consequence, does not apply to the situation in rural Latgale. It is impossible to describe the rural conditions of Latgale as a totally consumer society. However the ideals of a consumer society are the firmest ones and magazines as reading material promote the integration of rural communities into the model of a consumer world. 
Just like in the large cities, the favourite magazines in the countryside are two explicitly consumer-orientated ones - the so-called tabloid Privāta dzive (Private Life) and a magazine for housewives Ieva (Eve). For example, about $35.7 \%$ of all our respondents in Latgale stated they were active readers of Ieva or /and its supplement in comparison to $0.5 \%$ of respondents in Latgale that said they read the most popular household magazine Praktiskais Latvietis (Practical Latvian). The readers consider magazines to be entertainment and a platform for social interaction, because they provide material to be discussed with others and demonstrate the values of a material world. For rural inhabitants, the environment portrayed in the magazine is often viewed as a fairytale or dream world, and is seen to be motivating - "now I can dream a bit". The women's magazine Ieva operates with a wider scale of signs. It has its own "glamorous" section, which includes stories about the lives of female celebrities. In most cases they are success stories, but are not as ostentatious or simplified as those featured in Privātā dzīve, where the greatest human achievements are reduced to new cars, houses and wives. In the case of Ieva they are based more on verisimilar life stories, where the difficulties of life and overcoming them are also featured. These are the stories that have a sympathetic and supporting audience among rural women, whose everyday lives are not the easiest. It is not without reason that Ieva has created a special monthly edition of Ievas stāsti (Ieva's Stories), which, in a way, is a sub-product of literature that employs the methods of prose rhetoric to tell stories about real people.

The magazine Ieva fulfils a particular ritual function by providing emotional excitement. It temporarily expands the reader's world, allowing her to detach herself from her everyday world for a moment. The magazine organises summer camps for their readers, and the readers participate in contests in order to be selected. Another of the magazine's important features is its practical advice section - beauty care, clothing, cooking, and home furnishings.

\section{Latgallian language and Latgallian literature}

The intellectuals of Latgale are proud, that the Latgallians have a written language of own that has developed historically in Latgale. There is still some disagreement among linguists about spoken Latgallian - is it to be considered a separate language or a dialect of Latvian? However, the written language has existed for many centuries and is still being cultivated with the help of various activities, including the publishing of periodicals and books.

There are many enthusiastic young people, who consider written Latgallian to be their only authentic linguistic existence, and accordingly Latgallian poetry, prose and drama is being produced. If over many of the past decades the aspect of regional identity was predominant, after the restoration of Latvian independence, a myriad of literary activists emerged, for whom the main wish and calling is to be modern avant-garde aesthetes, pioneers of a new poetical expression, and the revealers of the depths of their language and local culture. 
Adhering to these principles, Valentins Lukaševičs (1968), who is a Latgallian writer and lecturer at the University of Daugavpils, has gained wider recognition beyond the regional borders by writing his texts in Latgallian. In comparison, about $17 \%$ of our respondents have never heard the name Valentins Lukaševičs or read his works. More popular in the Latgale region is Anna Rancāne (1959) who writes in Latgallian as well as in the Latvian literary language $-64 \%$ of the respondents in Latgale have heard of her.

If we turn our attention the perception of Latgallian literature inside Latgale, a less intriguing view is revealed. Thirty percent of the inhabitants who were surveyed use Latgallian as a conversational language on a daily basis. Still, the visits to the survey sites lead us to the observation, that the boundaries between the national version of Latvian and Latgallian are very fragile. The Latgallian language that is used on a daily basis functions as a peculiar hybrid that includes a large portion of lexical admixture from Russian. The respondents' answers attest that the users of the language are quite indifferent to the special cultivation of the everyday speech, its development and maintenance.

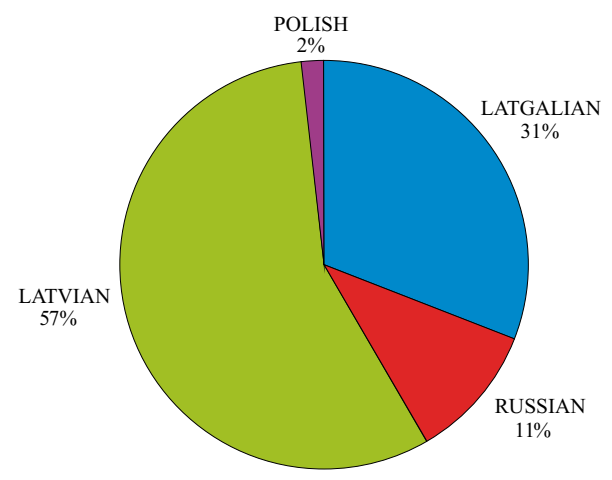

Figure 2. Use of languages for everyday communications in Latgale

In addition, the answers also reveal that written Latgallian occupies a fairly stable place in the religious (Catholic) life of the region, since women comprising about $13 \%$ of all our respondents read their prayers, the Bible and other religious texts in Latgallian.

Along with the administrative isolation, the confessional aspect must be seen as an essential motive for the genesis of written Latgallian. The status of the written Latgallian is exceptionally stable in religious texts.

If, on one hand, the most popular magazines among young women are the national illustrated women's magazines, none of which are published in Latgallian, among elderly female readers, the magazine Katolu dzive (Catholic Life), which is published in Latgallian, is held in high esteem. Everywhere, there are groups of people, mostly teachers and librarians, who are well informed about Latgallian literature both from a historical and contemporary point of view. 


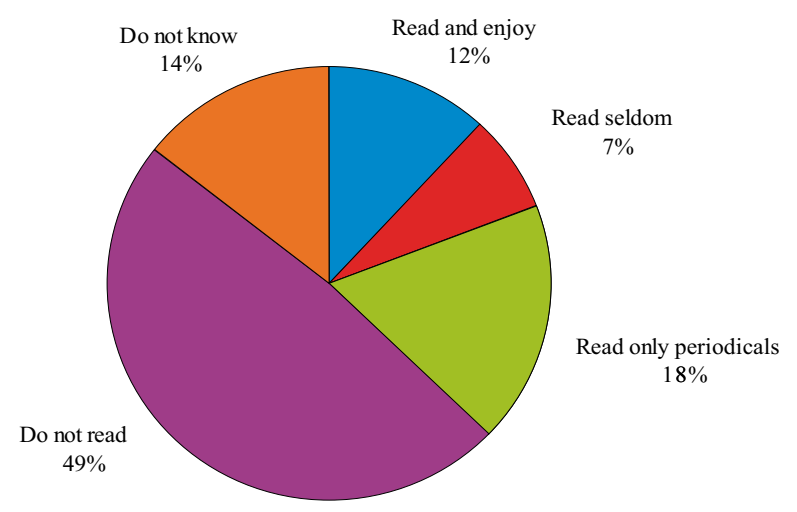

Figure 3. Reading in Latgallian

\section{Conclusions}

1. Latgale, which a district region of Latvia, is not without its specific reading traditions.

2. Most of the local inhabitants have small home libraries. Books are seldom bought and periodicals dominate the locals' reading habits.

3. Modern local talents, even those with poor creative abilities, are held in higher regard than the modern writers that are widely acknowledged in the urban areas.

4. The local language - the Latgallian dialect - plays a significant role in the spiritual life of the local inhabitants, and also reveals its importance in the intellectual world and reading traditions of the region. Although publishing and reading books in the local language is appreciated only in a closed circle of intellectuals, it can still be regarded as a way of strengthening the self-confidence of the entire region.

\section{References}

Bourdieu, P. (1979). La Distinction: critique sociale du jugement. Paris: De Minuit.

Kemps, F. (1910). Latgalieši. Kultūrvēsturiska skice. Rīga: D. Zeltiṇa ġenerālkomisija.

Lyons, M. (2010). A History of Reading and Writing in the Western World. Basingstoke:

Palgrave Macmillan.

Mazhurina, K. (2009). A Note on the Soviet Union and Post-Soviet Russia. In S.E. Quay (Ed.), Cultural History of Reading. Vol. 1. Westport, Conn \& London: Greenwood Press.

Rožukalne, A. (2011) Kas? Kur? Kāda? Mūsdienu mediju auditoriju. Rīga: Turība. 


\title{
'New reading' or communication? Finnish students as readers in the age of social media
}

\author{
Juha Herkman, Eliisa Vainikka
}

\begin{abstract}
Introduction
This article investigates how the idea of the 'digital revolution' challenges contemporary conceptions of reading. Finland is an interesting case for this kind of research, because the country has been identified as one of the most advanced information societies in the world, even though it has slightly lagged behind countries such as the U.S., Japan, South Korea, and certain European countries, in the use of broadband connections and social media during the $21^{\text {st }}$ century (Turkki et al. 2009). At the same time, Finland and the other Nordic countries still have strong reading cultures (Griswold et al. 2011). Finland is demonstrably among the top countries in the world in regard to the number of printed books, newspapers and magazines published per capita (Finnish Mass Media 2010: 226-227). Finland also continuously ranks high in international comparisons related to the literacy skills of schoolchildren, for example, the OECD Programme for International Student Assessment (PISA). Furthermore, national surveys indicate that, in Finland during the past 20 years, the average time spent on reading has not significantly decreased even though new media and communication technologies have spread among the population (Ekholm and Repo 2010: 55; Statistics Finland 2009).

However, it is clear that this spread of networked media and communication technologies has also radically challenged the reading habits in Finland. The circulations and reading of printed newspapers have continuously decreased and the use of the Internet, mobile devices and social media has increased. This is especially true of the younger generations who, according to many reports, have adopted the Internet and social media as their most important media and source of information (15/30 Research 2011; Statistics Finland 2011). The
\end{abstract}


printed newspapers in Finland lost 16\% of their readership during the first decade of the $21^{\text {st }}$ century (Finnish Mass Media 2012: 62-65, 84-88). Even if the number of published books and average time spent reading books has not plunged, the number of loans from public libraries has radically declined since 2004, and, in 2010, the turnover of books also decreased for the first time after World War II (Alanen 2011). These changes indicate new reading habits that are thought to be more short-term, interactive and social in nature than former reading practices. As the media scholar John Hartley (2005: 12) has put it, "with interactivity, customization, and the evolution of media from 'read only' to 'read and write', the relations between audiences and creative content have irrevocably changed, even while existing forms persist".

This article explores the contemporary media use and reading habits of Finnish students, who - according to Don Tapscott's (1998) definition - can also be described as representative of the 'Net Generation'. However, our special focus here is on the older students between the ages of 18 and 30, who can be seen as a transition group between the younger 'digital natives' born in to a world with social and ubiquitous media, and the older generations of 'digital immigrants', more familiar with print and broadcast media (see Herring 2008: 72; cf. Prensky 2001: 1-6). We examine whether the idea of 'new reading' can be verified among Finnish students and what kind of readers they actually are. We also examine the origins of the students' reading habits and the direction in which they are moving. The roles played by printed and electronic publications, as well as social forms of reading, are of particular interest to us. More precisely, our research questions are as follows:

- What are Finnish students reading in the early $21^{\text {st }}$ century?

- How and from where do they select their reading materials?

- How do they read?

- What role do ICT and the new forms of electronic text play in their media use and reading habits?

- How revolutionary are their reading habits compared to the previous studies of Finns as readers?

\section{Theory of 'new reading'}

Until the 1970s, reading was understood primarily as a private cognitive activity based on understanding the alphabet and reading written texts, which were mainly fiction. The pioneers of British cultural studies, Richard Hoggart (1957) and Raymond Williams (1963), started to challenge this way of thinking as early as the 1950s and 1960s by emphasising the social aspects of cultural consumption. But it was not until after the so-called post-structural turn of the 1970s and the spread of cultural studies that reading was viewed more broadly by the humanities and social sciences. The French literary scholar and 
philosopher Roland Barthes introduced his ideas about the 'death of the author' and the meaning of 'text' in the early 1970s. Barthes (1977) recognised that meaning is created by the process of reading 'texts', rather than by the ideas of some genius author being interpreted from a literary work. Stuart Hall (1980), another pioneer of British cultural studies, applied the Barthesian idea in his famous model of 'encoding/decoding', in which both the text creator's conscious and unconscious intentions as 'preferred meanings' are sutured into the text (encoding) and their interpretation as a socio-cultural process of meaning-making (decoding) are taken into account. After these theoretical developments, cultural scholars have studied the process of reading as it applies to a whole range of everyday cultural texts ranging from those in shopping malls to the ones on surfing beaches (e.g. Fiske 1989) and book reading has also been considered to be a cultural and social practice (e.g. Radway 1987).

Literacy research has changed along with the theories of reading. Already in the 1990s, the New London Group, a group of scholars studying media education, developed the idea that reading cannot be separated from writing. Rather than focusing on the technical cognitive skills of reading, they borrowed poststructural text theory and emphasised the process of meaning-making. From the perspective of the New London Group, listening and reading are aspects of text production - these are meaning-making processes based on a person's individual and social interests and experiences (Cazden et al. 1996). Since then, the theories of 'new literacies' have emphasised the social nature of reading and writing (e.g. Lankshear et al. 2002: 2). These new ways of understanding literacies have also been called 'the theory of socio-cultural literacy' (e.g. Lankshear and Knobel 2003).

More recently, the changes in media environments have encouraged literacy scholars to understand reading more broadly as interpretative practices used in connection with all kinds of media (Gee and Hayes 2011). In contrast to printed texts, the Internet highlights the multimodal text forms that combine various modalities of language, image and sound (see Kress 2003; Lehtonen and Herkman 2002), while also blurring the distinction between the producers and receivers of these texts (Luke 1995). On the Internet, sociability, interaction and even the production of texts are often considered in addition to the cognitive skill of reading (Gee 2008: 40). In this sense, in the current media environment, reading is very closely related to writing.

The 'new reading' thus refers to socio-cultural literacy, in which reading is defined as textual practices in which meanings, interpretations and texts are created from many different text-types in the networked media environment. All meaning-making includes interaction and a connection with other people, and therefore, the 'new reading' is also communication in which the community may play a crucial role. This study examines whether the empirical analysis of Finnish students' reading habits supports the idea that 'new reading' is radically usurping old reading practices. Here we understand reading to consist of 
various practices related to reading and writing that take place in the contemporary media environment, including texts published in printed and electronic forms and delivered by professional media companies or through social media services. Therefore, the emphasis is on written text-forms of interpersonal and peer communication or on professional and amateur publishing on the Internet, rather than, for example, audiovisual text-forms, such as television, video and cinema. However, consuming audiovisual text-forms is also studied here as part of the young adults' more general habits of media use habits.

\section{Research methods and materials}

The target group for our study is students aged 18 to 30 , who were born in the 1980s and early 1990s. They are said to represent the Net Generation, which was defined by Don Tapscott (1998) as the generation for whom the Internet became a natural part of their lives already in their childhoods. The oldest participants in our study became familiar with the Internet as adolescents, the younger ones as children. Most of the media use studies today focus on younger age groups (5-20-year-olds), since these 'digital natives' are the focus of media education and are of interest to (future) media markets (e.g. Pääjärvi 2012; Livingstone et al. 2011; Ito et al. 2010; Rideout et al. 2010). Therefore, the older segment of the Net Generation is an interesting subject for research because it forms a 'transition group' between the younger 'digital natives' and older media generations who grew up with the printed word and television, rather than the Internet (cf. Herring 2008: 72).

Three different sets of research materials are used for this study: a survey, media diaries and focused interviews. The survey $(\mathrm{N}=323)$ provides an overview of the students' media use and reading habits. Media diaries $(\mathrm{N}=15)$ and focused interviews $(\mathrm{N}=15)$ complement the survey and create more in-depth knowledge about the roles played by media use and reading in the students' lives and daily routines. The survey is used mostly for obtaining frequencies and cross-tabulations, but also included some open questions about the motives and details of the students' media use. The focused interviews were relatively open-ended and the materials were transcribed and qualitatively analysed based on thematic classifications.

The survey questions focused on the media technologies, gadgets and applications owned by the students and how they used them. Also included in the survey were questions about the computers and social media activities of the respondents, their specific reading habits and user-generated content production. It was possible to consider the answers in relation to the background information on the students' ages, genders, study histories and hobbies. The media diaries covered five days of media use, including a weekend, and the focused 
interviews specifically examined the everyday individual and social reading practices of young adults.

The 323 respondents participating in the survey were students aged 16 to 35 in the Tampere region of Western Finland. With a population of about half a million, Tampere and its surroundings form the second largest urban centre in Finland after the capital Helsinki. About $60 \%$ of the survey respondents were university students, $30 \%$ were students in upper secondary schools and $10 \%$ attended other institutions, such as polytechnic schools. Most of the university students were studying humanities or social sciences, but many of the respondents were also students of economic and computer sciences. The fifteen respondents who filled out media diaries and participated in the focused interviews were communication and media undergraduates at the University of Tampere. The research material was collected in the spring of 2011.

The survey sample was not demographic nor was it representative of the Finnish population, although our results are quite similar to those for the national statistics for the age group. Nevertheless, the sample reflects the experiences of most Finnish students of that age, whose lives revolve around studying, part-time or fixed-term jobs, relationships, searching for permanent jobs and starting families. In general, our aim was to qualitatively analyse the changing reading habits of Finnish students in the age of social media. Our materials serve this purpose well. Because of the stage they had reached in their lives, the participants in our study were active readers and users of various text forms. Because of their availability and activity, students have also been used as respondents in many other studies on reading habits (e.g. Connell et al. 2012; Parlette and Howard 2010; Kang et al. 2009; UCL 2008; Braguglia 2005).

\section{Results}

Among twenty-something Finns, the Web is more popular than the previously most popular medium, television, and consequently most of the reading in our study was focused on different texts published on the Internet (cf. Statistics Finland 2012). Almost all the participants had Internet connections in their homes, and many respondents also used their mobile phones to connect to the Internet. In this sense, it is legitimate to speak about the 'Net Generation'.

Most of the respondents in our study became familiar with the Internet as adolescents, when Internet connections arrived in private homes. Generally, Finnish households started installing Internet connections around 1994 when the first graphical web browsers appeared, although some homes already had Internet connections starting in the late 1980s. In Finland, local libraries and elementary schools also played a significant role in the introduction of the Internet to schoolchildren in the early 1990 s. 
In general, $21^{\text {st }}$ century students are familiar with social media: $60 \%$ of our survey respondents said they used social media at least one hour per day. We defined social media as various online services (e.g. Facebook, Twitter, blogs), where users form networks, communicate with others, and follow, share or produce content. The most popular motives for Internet use were communicating with peers and entertainment. According to our survey, the most popular Internet application was Facebook, with $86 \%$ of the respondents having a Facebook account. This figure is an even higher share of the age group than in the 2010 national survey of Finnish ICT use (Statistics Finland 2011).

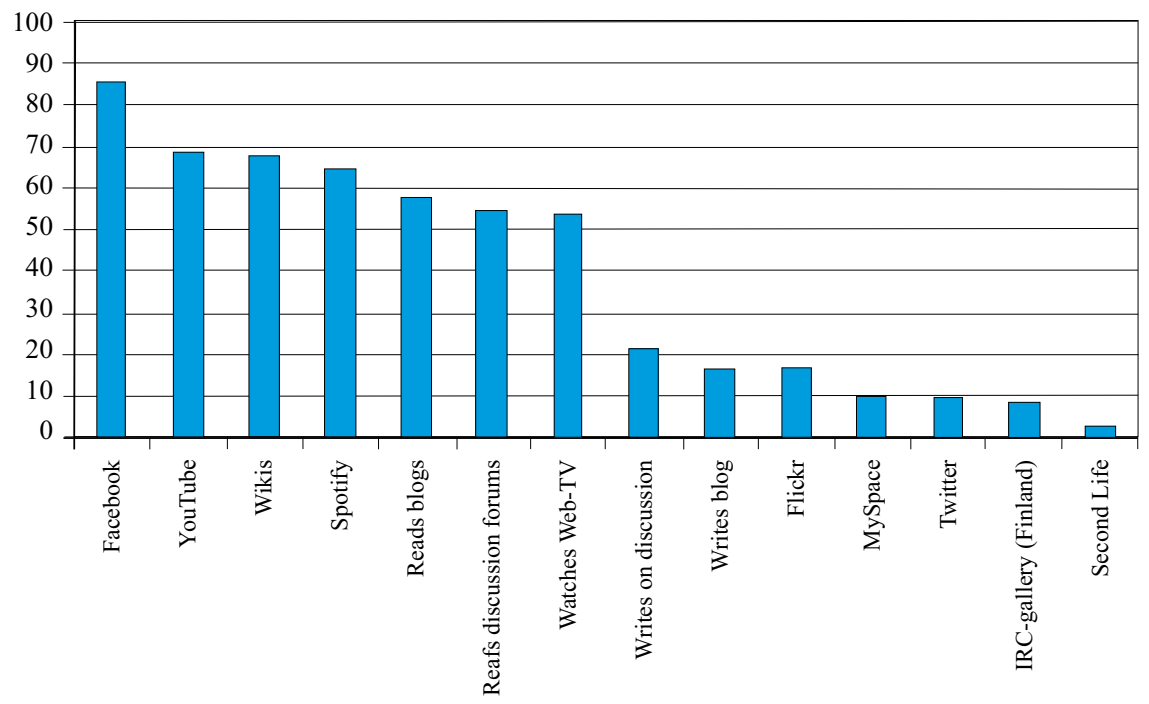

Figure 1. Social media use (percentage of all respondents, N=323).

The focuses of and motives for Internet use also reveal the most popular text types and forms preferred by Finnish students today in their reading. They are interested in interpersonal and social communication, and therefore short communicative texts, such as notes, debates and messages, which are the most often read text forms (see Figure 1). These texts more closely resemble face-to-face discussions than the traditional consumption of media content or the reading of printed books. Of course, students also read content produced by professionals or semi-professionals, but, in our study, the Internet appeared primarily as a space for social interaction and presenting oneself to others, i.e. literally as 'social media' (cf. Ridell 2011; Boyd 2008).

The idea of multimodal texts is often a good description of the online texts that combine various media forms and modalities of language, sound and 
image (cf. Kress 2003). According to our survey, in addition to Facebook, other multimodal text environments, such as YouTube, Wikis, blogs and discussion forums, were also popular among students. Two-thirds of the respondents reported having used YouTube, Spotify or Wikis, and more than half had read blogs or discussion forums. The reading of Wikis, blogs and discussion forums increased with age and was less popular with those who still lived with their parents (cf. Statistics Finland 2012).

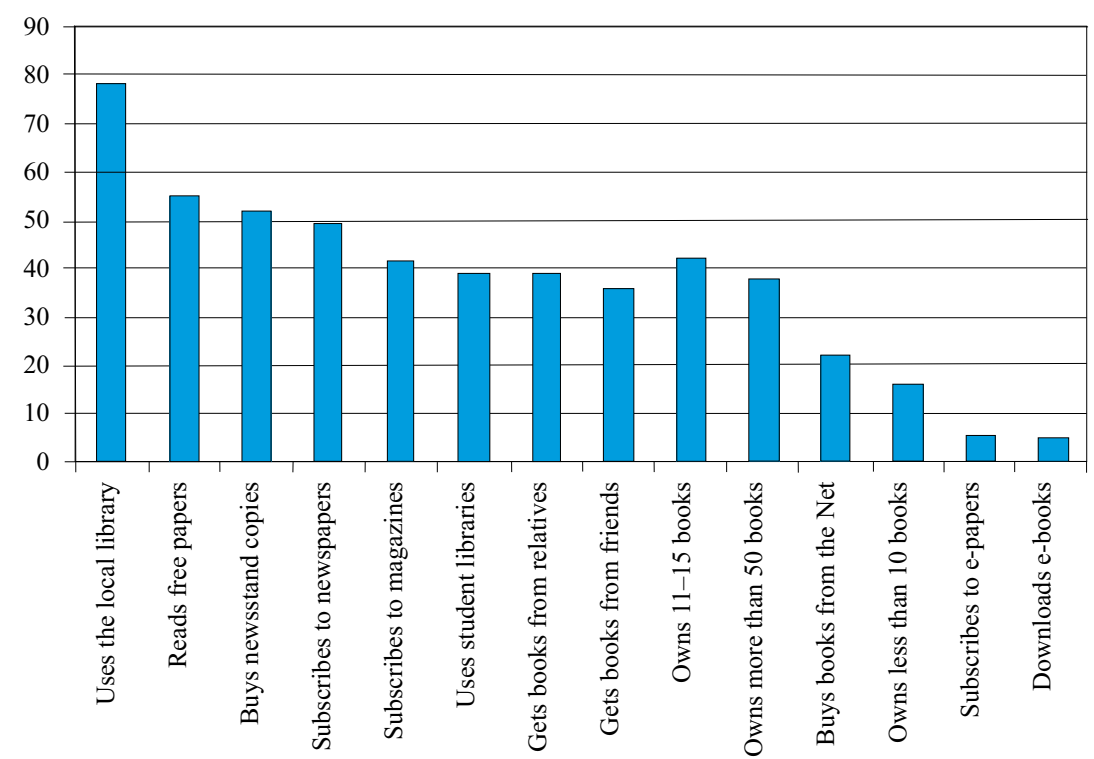

Figure 2. Share of print media consumption among survey respondents ( $\%$ of all respondents, $\mathrm{N}=323$ ).

Although the Internet was the most popular media for the students, they still value print media (see Figure 2). Half of the survey respondents subscribe to a newspaper - most often the leading regional paper. And some respondents also subscribe to a second newspaper. Those who did not subscribe to newspapers read free papers either in print or in electronic form. The media diaries and interviews also showed that reading the newspaper in the morning is still a common morning ritual for many of the respondents. In this sense, statements about the death of newspapers seem premature. However, some newspaper reading is now done online, rather than reading the printed paper edition, so printed newspapers were not self-evidently the only focus of the students. 
The reading material that engendered the most positive responses was, somewhat surprisingly, the printed book, which was highly appreciated. The students in our sample actively come in touch with various texts and may therefore appreciate books more than young adults generally. But the interviews and open survey responses also indicate that the desire to read fiction dates back to the time in their lives before they were studying in academia. Being socialised as readers has been an important path to successful literary skills and print industries in Finland. For instance, some respondents said the following:

... when I was a kid we had a really positive atmosphere for reading at home [--] we always had a lot of books available. And when I could not yet read myself, my parents read books to us. (Woman, 23)

I have always been told that reading is important and that it should be practiced. [--] When I was young, my parents stressed the significance of reading newspapers and literature. So, I guess this is where my reading models originate, and therefore, I still read the newspaper every morning. (Woman, 21)

My mother reads a lot and we have always read a lot [--] as I said about reading newspapers... of course, my parents read the paper in the morning and this set the example at home. (Woman, 25)

Even the most enthusiastic computer nerds dreamt about collecting their favourite books on bookshelves, providing they have enough money to buy them in future. Therefore, the visions of a future, which are sometimes suggested and in which electronic forms of visual media totally replace written texts, may in fact not be true, especially not in high-literacy societies such as Finland.

Eighty-five percent of the survey respondents owned more than ten books, and $40 \%$ owned more than 50 books. Reading fiction was especially appreciated as a leisure-time activity, but many interviewees claimed that they had little time for leisure-time reading because of the time they have to spend studying and working. In many cases reading textbooks and study materials was also seen as a hindrance to reading for pleasure:

I pretty much read on holidays and in the summer. I go out after work, if the sun is still shining, and then I always take a book along... Usually I'm in school from nine to seven so I'm too tired to read in the evenings anymore. (Woman, 23)

My reading has turned from fiction and leisure-time reading to reading for exams. It seems that I'm always reading lots of books for exams and have no time for relaxing, leisure-time reading. (Woman, 25) 
The most popular works of fiction among young adults in Finland have changed radically since the 1990s. According to Finnish studies of literature readership, at that time, the most popular authors were men and the most popular fiction was written by national authors (Eskola 1990: 37-43). In the $21^{\text {st }}$ century, young adults prefer foreign books in the fantasy genre, with the most popular authors being J. R. R. Tolkien and J. K. Rowling, who are appreciated as much as the leading national authors used to be, and still are, by the older generations of Finnish readers (Eskola 2009: 134-137).

Our study supports the idea of change, although our survey also demonstrates that contemporary Finnish authors continue to be popular among students. One reason is the popularity of both Finnish and foreign crime and detective stories; another is that national authors and Finnish classics are included in school curricula. However, in general, one could say that reading has shifted from national to global content, and the gender of the author no longer plays a significant role. For contemporary students, the genre and content of the books constitute the main reasons for making their reading choices; and the importance of national traditions or identity formation seem to be a less important motive for determining their book reading habits (cf. Leppänen et al. 2009). Of course, there could also be important social motives behind these reading choices, which could even lead to joining the transnational reading communities on the Internet.

\section{The value of reading in everyday life}

The reading habits of young adults are largely determined by their life situations. The students that participated in our study devoted most of their time to their studies and work and this determined what they read and the focus of some of their media use. Many of the respondents were worried that they did not have enough time for leisure-time reading. Their life situations could even affect their choice of text types and genres, for example, respondents with small children preferred shorter text forms. Therefore, the reasons for choosing certain texts may be very practical or even based on chance rather than on communication technologies, user interfaces, or conscious decisions or preferences.

On the one hand, students' lifestyles offer a certain degree of freedom; and the respondents did not necessarily make a clear distinction between work, everyday routines or leisure as seen in the example below. Also, the distinction between weekdays and weekends in their lives was often not clear. Therefore, reading is not necessarily linked to the releases and delivery schedules of professionally produced texts but it is more of an autonomous everyday practice, in which various mediated texts stream through their lives.

At noon I took a break from writing and watched the previous day's episode of Emmerdale on television. At the same time, I had my laptop on my lap and I 
was correcting the work I had written earlier [--] so the television replaced the radio as background noise, occupying more of my attention. During the commercial breaks, I worked more actively. (Woman, 25)

The media diary and interview data support the idea that online reading usually follows a daily routine and consists more of quick 'viewing' than focused 'reading' (see Ekholm and Repo 2010: 100; Nielsen 2006). This 'new reading' is based on speedy online communications, much of which is comprised of messaging with friends (Weinreich et al. 2008). The daily Internet routines included checking e-mails, Facebook streams, and certain favourite sites and updates, often in the same order everyday. The favourite sites included online newspapers and the websites of other media brands, as well as blogs and discussion forums related to hobbies. Regardless of these routines, a certain element of chance still exists in online reading, as links lead readers to sites they had not originally intended to visit. According to the interviews, quick viewing is not limited to reading online materials. Newspapers in particular may be read similarly to websites - skimming the headlines and glancing at the pictures. The reader stops for focused reading only when something especially interesting appears.

According to our study, the online reading outside of interpersonal communications could be roughly divided into three main categories: (1) checking online news, (2) reading texts related to studies and (3) seeking information on the Web. These categories were represented in most media diaries and interviews as common reading practices. Online news was seen by the students as a part of their daily reading routines, whereas the two latter categories were more related to their tasks as students. From the data, one can also infer that electronic texts are more related to work and studies and printed texts to leisure time, with the exception of blog reading, which falls into the leisure-time category.

Some of our respondents reported that online reading occasionally leads to the focused retrieval of information on a specific topic, and sometimes to even trying to access the original source of the information via the Web. However, the consensus of the interviewees was that they usually focused better on printed texts than on online texts. They even described reading printed texts, especially novels, as an intimate activity.

In connection with the above, the students had a surprisingly negative view of electronic publications. They specifically wanted to read books in print. A printed book was considered an excellent user interface that was significantly more convenient to read than a text on the screen. In general, the survey respondents and participants in the focused interviews did not consider computer screens or mobile devices good user interfaces for reading long texts. The interviewees had the following to say: 
I feel that reading on a computer screen is off-putting, and does not seem to be reading... it is somehow much easier to read a printed book while lying on a couch. Printed textbooks can also be underlined and taking notes is easier. However, this is perhaps just a question of adjustment. (Woman, 21)

If I want to read in my free time, I will definitely choose a printed book. It is part of the whole experience to hold a book in your hand... not needing to read online texts on a screen or display. And if I want to read an interior decoration magazine or other periodical during a train trip, for example, it is much nicer to read a printed magazine. (Woman, 25)

The criticism of e-publications also included the fact that the respondents felt the availability of Finnish e-books is far too limited and their use too difficult because of various copyright and data protection systems. The interviewees did not understand why they should pay for electronic publications if it was possible to access the same content as a printed object, which could be kept or even resold. Nor did they believe that the current e-books could be read in the future as the devices, applications and formats are constantly changing. The comparison of printed and electronic books based on the survey responses and open-ended interviews are shown below in Table 1.

Table 1. Printed books vs. e-books (based on the survey and interviews).

\begin{tabular}{l|l}
\hline Printed books & e-books \\
\hline $\begin{array}{l}\text { Comfortable to read (except for large } \\
\text { books) }\end{array}$ & $\begin{array}{l}\text { Computer screen not comfortable to read (may } \\
\text { change as e-readers become more popular?) }\end{array}$ \\
\hline Enjoyable user-interface & $\begin{array}{l}\text { Difficulties with data protection and copyright } \\
\text { protection }\end{array}$ \\
\hline $\begin{array}{l}\text { Keeps its value, durable, can be used } \\
\text { anywhere }\end{array}$ & $\begin{array}{l}\text { Disposable, may not be usable if format } \\
\text { standards change }\end{array}$ \\
\hline A broad selection of titles & Selection of titles not broad enough (for now) \\
\hline $\begin{array}{l}\text { Availability uncertain, not available } \\
\text { immediately, circulation is rapid }\end{array}$ & $\begin{array}{l}\text { Available quickly, not limited to a specific } \\
\text { place or time, the 'long tail' (older books also } \\
\text { available) }\end{array}$ \\
\hline Paper not an ecological material & Eco-friendly (no paper needed) \\
\hline Broad price range & $\begin{array}{l}\text { Should be significantly more affordable than } \\
\text { printed books }\end{array}$ \\
\hline
\end{tabular}

One reason for preferring printed text forms was perhaps the fact that only a few students participating in the study had a tablet computer or an e-reader at their disposal. Tablet and e-reader displays are more convenient to read than traditional computer screens, but they have yet to make a breakthrough in Finland as reading devices. At the beginning of 2012, only $6 \%$ of households in Finland had such devices (NextMedia 2012; cf. Findahl 2012: 18). However, 
tablets did not increase in popularity in Finland until the early 2010s; according to a consumer barometer, $16.7 \%$ of Finns between 15 and 74 used a tablet in the spring of 2013.

About half of our original survey respondents answered the follow-up questions about owning or acquiring a tablet computer or e-reader in 2012. The follow-up study confirmed that Finnish students were not very eager to purchase e-readers or tablet computers, although their use has increased somewhat during the year. On the other hand, smartphones had already made a breakthrough with nearly two-thirds of the respondents saying that they had one or were planning to get one by the end of 2012. Although people use their smartphones for browsing the Web, they seldom read e-books or other longer texts on their phones (see Finnish Mass Media 2012). Students need smartphones for their interpersonal communications, and laptops or PCs for their studies and jobs. In this sense, tablet computers and e-readers are non-necessary devices for students, who purchase these gadgets only if they have money to spare. So far, tablets have been acquired in Finland mostly by wealthier middle-aged men and families who are fans of new technologies (NextMedia 2012).

To summarise, books, papers and magazines are valued as objects to relax with, but students do not have as much time for reading as they would like. Electronic books are not yet within the reach of Finnish young adults in terms of their usability, availability or pricing, nor do they enjoy the same value judgments as printed books; whereas online texts, such as news and blog posts, are commonly in use as multifaceted everyday texts.

\section{Reading or writing?}

Our study concurs with the other research that indicates that most Finnish Web users consume material made by other people, instead of producing their own content (e.g. Matikainen 2011: 22-23; Sirkkunen 2009: 354). Facebook is an exception, if its use can be understood as 'media production'. Creating one's Facebook profile requires some level of content production, even if the user does not choose to update the profile after creating it (see Ridell 2011: 89).

Almost nine out of ten survey respondents had Facebook accounts. However, most of the interviewees in our study reported their Facebook use was limited to quickly logging in to check their friends' status updates and to see if something interesting had happened. The respondents were quite protective of their own privacy and did not want to share too much about their private lives on Facebook. These results are in line with Seija Ridell's (2011) study on Finns as Facebook users, where most of the users acted as an 'audience' for their friends, and only a small portion of users actively published information about themselves. This shows that social media does not necessarily make media use into active participation in the sense of user-generated content 
production or 'collective intelligence' (cf. Jenkins 2008), although it does include more interactive practices of communication, and the linking or sharing of materials, than does traditional mass media. As Andreas M. Kaplan and Michel Haenlein (2010) have noticed, many social media services are based on community networks and communication, and only some are formed around specific content production.

However, in addition to Facebook, several other modes of participation also appeared in our research material. Of the survey respondents, $60 \%$ reported having written on a discussion forum at some time, and more than a third had commented on a blog. There were fewer respondents who shared and linked content, or produced and published their own content. Ten to twenty percent of the survey respondents reported publishing texts online, whereas less than one tenth published images such as photos, drawings or videos. Nevertheless, the share of content production in our study is higher than in most studies on online use, which affirm 'the $1 \%$ rule', i.e. only $1 \%$ actively produces content that 9\% comment on and 90\% merely follow (e.g. van Dijck 2009: 44). The result describes the activity and potential of students for producing their own online content. In our survey there was also a positive correlation between blog reading and reading books that are unrelated to their studies. In general, the students proved to be more active readers in both traditional and new reading than critical studies on Internet use would suggest (cf. van Dijck 2009).

According to our survey, the oldest group of young adults were surprisingly the most active producers of their own content (see Figure 3). The younger ones, especially those still living with their parents, preferred entertainment media and 'passive' media use (for example, watching television). The stage of their lives did not necessarily encourage active media practices other than interpersonal communication. Therefore, our study supports the argument that 'digital natives', or the innate technological skills of youngsters, may be attributable more to the expectations and interpretations of the older generations and researchers than to the actual experiences of the young people (see Buckingham 2008; Herring 2008). Our data shows that the older respondents clearly have greater technical skills and more opportunities to produce their own material. Studies, training and experience seem to have a significant role in how young adults use the Internet and create media, which indicated by the fact that, in our study, communication and computer sciences students were the most active producers of their own media content. Some interviews revealed that the members of certain recreational communities are also active producers of content, which is often related to their community interests, but which they do not necessarily publish online otherwise.

However, the students highlighted the social aspects of reading more often than their own content production. It is common for readers to talk to others about the texts they have read, and the reading experience is often something that they want to share and compare with others (cf. Collinson 2009; 
Pagliassotti 2008; Radway 1984). Also, people often find reading material based other people's recommendations. According to our data, survey respondents and interviewees preferred talking about reading books with friends and relatives in person rather than using communication technologies. Book recommendations were also appreciated more if they were delivered personally by a close friend or trusted person.

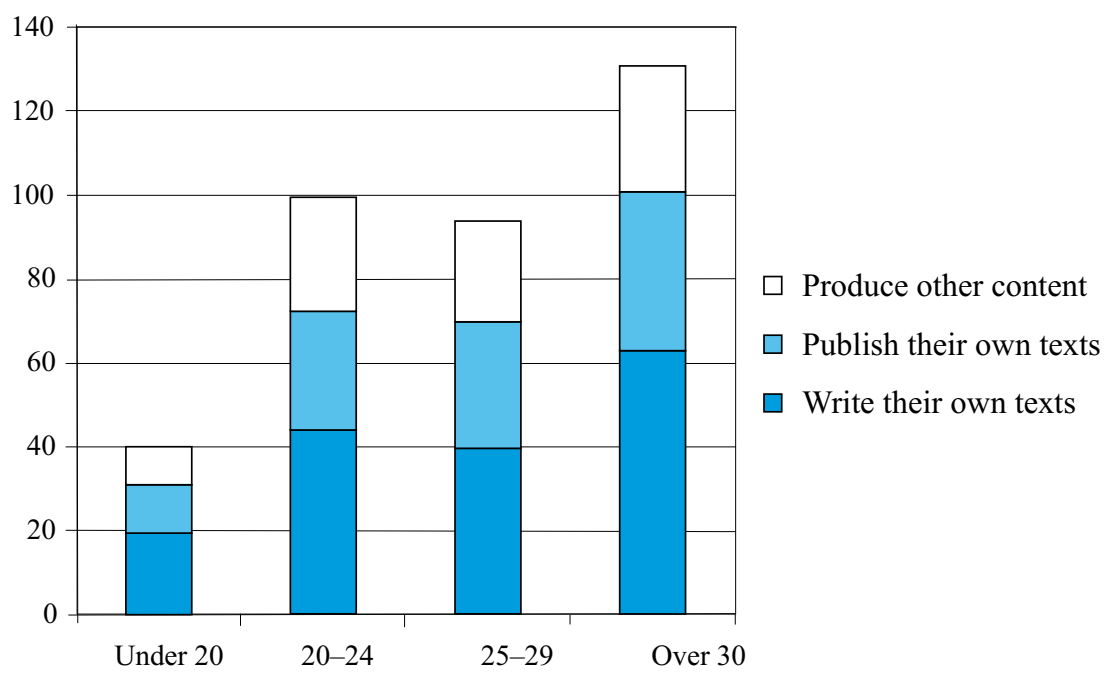

Figure 3. Students of different ages as content-creators (number of survey respondents in the age group, $\mathrm{N}=323$ ).

Nevertheless, the focused interviews showed that social media was very important in determining online reading. Friends both recommended blogs and wrote blogs that the readers were interested in. Friends were also an important audience for the blogs written by the students. Therefore, using blogs was closely connected to friendship networks, although none of the interviewees actually belonged to a concrete 'blogging circle'. Similar discussions and recommendations for reading and texts were also essential in other online forums; especially in the recreational communities that were integrally linked to their participants' identity work (cf. Stern 2008). However, for many participants in our study, Facebook was the only online community in which they participated, and most of the interviewees described their Facebook use as fairly passive, consisting mainly of following their friends' updates. 


\section{Discussion}

Our qualitative interview data revealed that reading was still seen as a fairly private experience - something that readers wanted to do by themselves. In this sense, reading is still understood primarily as an individual cognitive skill of understanding and interpreting (printed) texts. On the other hand, most of the students' textual practices were related to online communication and social media, in which socio-cultural literacy plays a significant role, even though the respondents themselves do not necessarily consider these textual practices to be 'reading'. For them, these textual practices were mostly acts of communication with their peers and sometimes only undefined pastimes or entertainment - following what other people have published or delivered on social media networks.

The spread and naturalisation of the Internet as the most popular media for young adults does not mean that it is used innovatively or creatively for participation, nor does it automatically portend radical changes in other forms of reading. Quite the contrary, the informants themselves still perceived reading in a rather traditional way. Reading was still connected to printed texts more than it was to e-publications, and the longer the text, the greater the reliance on the printed form. There seems to be strong value judgments associated with leisuretime reading; and printed books still seem to engender great trust, even among people at the forefront of developments in communication technologies.

However, this result should be regarded somewhat critically; many subconscious beliefs and valuations are involved in the appreciation of books (cf. Lehtonen 2001). There are also people who appreciate books although they are not active book readers (Griswold et al. 2005). Therefore, one cannot be certain whether young Finns are really pro book, or they have just adopted a set of values that will change along with developments in the media environment especially the proliferation of tablet computers and other devices, which are better suited for reading e-publications than computer displays or smartphones. Moreover, a large number of participants from academia, who traditionally favour books, may have skewed the results in this respect.

However, the interviewees claimed that the main obstacle to leisure-time reading was the lack of time, which was most often attributed to the demands of academic studies. The media diaries and interviews also revealed that the scheduling of Finnish twenty-something students' lives are casual - work and leisure-time activities overlap and the differences between weekdays and weekends may be unclear. Therefore, it seems that even if students do appreciate reading printed publications, especially fiction, at this stage of their lives, other forms of reading are more important, such as study materials, light entertainment and online communication, which are connected to their studies, jobs and social lives. 
Our study demonstrates that young adults tend to use the Internet for repetitive daily tasks rather than for the innovative or pioneering development of new content. Therefore the assumption that the Net Generation is innately active, creative and participatory seems to be false. According to our study, the Web use by the majority of students is 'banal' or mundane rather than creative (cf. Buckingham 2008: 14), and contrary to the assumption about 'digital natives', the most active and participatory young adults in our study were the older ones who had greater technical skills and more opportunities to produce their own material (cf. Statistics Finland 2012). Instead, the younger ones watched more television and were more passive in their media use, in the sense that they did not produce as much original material as the older ones. In general, our study indicates that education, resources and training are more relevant to various reading activities than age. Therefore, reading habits vary depending on the stage of the person's life.

Earlier studies have shown that the transitions from one stage of life to the next change a person's personal interests and lifestyles, thereby also creating different needs for media use (Findahl 2012: 10). It would be surprising if the media use habits of today's children did not change as they mature - start studying, working and establishing families. Therefore, the future cannot be totally accurately predicted based on the media use of the youngest generations.

The contextual differences related to reading should also be kept in mind. Most of the scenarios for future media use are based on Anglo-American or East-Asian contexts, where the use of new communication technologies is thought to be the most developed. However, the media environments, societies, education and national cultures of the Nordic countries, for example, have historically created different reading cultures than the Anglo-American environment (cf. Hallin \& Mancini 2004; Findahl 2012: 33). In the Nordic countries today, the ageing population retains traditional reading and media use habits. The high level of education also strengthens continuities in reading; most young people will still read printed texts as part of their studies in the future. In light of this study, a sudden leap or transition to a completely new kind of reading culture is not likely. The changes in reading will progress in the long-term as new media generations replace the preceding ones - but this usually takes more than 30 years (Herring 2008: 84). Social and cultural institutions, such as education and libraries, will play a crucial role in these changes. As the schools and workplaces start to use electronic publications, the reading related to work and studies will increasingly move towards immaterial environments, as has already happened in academia. 


\section{Conclusion}

Our study confirmed the assumption that Finnish students born in the 1980s and early 1990s are transitional readers, taking part in the traditional reading of printed materials and the 'new reading' activities of social media, rather than a completely new generation of readers. The new activities are different than those of traditional reading, because new reading is increasingly related to communication between people. However, so far, it still seems that, among young adults, different forms of media use complement (rather than compete with) each other as forms of reading (cf. Findahl 2012: 34). Although young adults spend a lot of time with short text forms for interpersonal and peer communication, they have not abandoned reading professionally produced texts and still appreciate printed text forms - especially books.

The complete adoption of global Internet practices may also have affected how students read printed publications, whereas the most popular reading subjects reveal that the cultural tastes of today's young adults are more international than those of previous generations. For example, they commonly prefer foreign - especially Anglo-American - fiction and genres, such as fantasy, over national narratives. In general, the reading habits of young Finnish adults are a combination of old and new forms of reading, in which old reading is highly valued, but the stage of their life impels them towards the task-oriented and communicative practices of new reading.

As the analysis provided by Raymond Williams in his classic The Long Revolution (1963), the revolution in communication technologies has played only one role in the long-term social changes, with the other historically significant players being the democratic and industrial revolutions. It could be said that more recently the emphasis on media and communication technologies has strengthened and they have become more central to all the institutions and processes of the economy, power and democracy, i.e. they have acted as a key factor of social change (e.g. Castells 1996). However, there are still several cultural, institutional, economic and ideological factors that continue to be important in social life. In terms of reading, one such cultural form is the long fictional narrative, which does not easily fit into the communicative forms of 'new reading', but stubbornly remains popular. Therefore, its important to see 'new reading' as a part of a long revolution, in which technological, institutional, social and cultural changes are linked to each other, rather than as a sudden leap in the more specific reading habits of individual readers or certain reader groups. 


\section{References}

15/30 Research (2011). Suomalaiset verkossa. http://www.1530.fi/2011/02/1530research-yle-suomalaiset-verkossa. Accessed 10 December 2012.

Alanen, A. (2011). Suomi on kirjastojen käytön kärkimaa. Kuinka kauan vielä? Tieto\&trendit , 4-5.

Barthes, R. (1977). From Work to Text. In R.Barthes. (Sel. \& transl. Stephen Heath), Image-Music-Text. London: Fontana Press.

boyd, d. (2008). Facebook's Privacy Trainwreck. Convergence: The International Journal of Research into New Media Technologies, 14(1), 13-20.

Braguglia, K. (2005). Reading Habits of Business Students. Journal of College Teaching \& Learning, 2(3), 67-72.

Buckingham, D. (2008). Introducing Identity. In D. Buckingham (Ed.), Youth, Identity, and Digital Media. Cambridge (Mass.): The MIT Press.

Castells, M. (1996). The Rise of the Network Society. Cambridge (Mass.): Blackwell.

Cazden, C., Cope, B., Fairclough, N., Gee, J., Kalantzis, M., Kress, G., Luke, A., Luke, C., Michaels, S. \& Nakata, M. (The New London Group) (1996). A Pedagogy of Multiliteracies: Designing Social Futures. Harvard Educational Review, 66(1), 60-92.

Collinson, I. (2009). Everyday Readers: Reading and Popular Culture. London: Equinox.

Connell, C., Bayliss, L. \& Farmer, W. (2012). Effects of eBook Readers and Tablet Computers on Reading Comprehension. International Journal of Instructional Media, 39(2), 131-140.

Ekholm, K. \& Repo, Y. (2010). Kirja tienhaarassa vuonna 2020. Helsinki: Gaudeamus.

Eskola, K. (1990). Lukijoiden kirjallisuus Sinuhesta Sonja O:hon. Helsinki: Tammi.

Eskola, K. (2009). Väinö Linna ja suomalaisten muut kirjailijasuosikit vuosituhannen taitteessa. In M. Liikkanen (ed.), Suomalainen vapaa-aika. Helsinki: Gaudeamus.

Findahl, O. (2012). Barn och ungas medieanvändning i Internet-världen. Göteborg: Nordicom.

Finnish Mass Media (2010). Joukkoviestimet - Finnish Mass Media 2009. Helsinki: Statistics Finland.

Finnish Mass Media (2012). Joukkoviestimet - Finnish Mass Media 2011. Helsinki: Statistics Finland.

Fiske, J. (1989). Reading the Popular. Boston: Unwin Hyman.

Gee, J. P. (2008). Social Linguistics and Literacies: Ideology in Discourse. London: Routledge.

Gee, J. P. \& Hayes, E. (2011). Language and Learning in the Digital Age. Abingdon: Routledge.

Griswold, W., McDonnell, T. \& Wright, N. (2005). Reading and the reading class in the twenty-first century. Annual Review of Sociology, 31, 127-141.

Griswold, W., Lenaghan, E. and Naffziger, M. (2011). Readers as Audiences. In V. Nightingale (Ed.), The Handbook of Media Audiences. Basingstoke: Wiley-Blackwell. 
Hall, H. (1980). Encoding/Decoding. In M. Gurevich et al. (Eds.), Culture, Society and the Media. London: Hutchinson.

Hallin, D.C. \& Mancini, P. (2004). Comparing Media Systems. Cambridge: Cambridge University Press.

Hartley, J. (2005). Creative Industries. In J. Hartley (Ed.), Creative Industries, Oxford: Blackwell.

Herring, S.C. (2008). Questioning the Generational Divide: Technological Exoticism and Adult Constructions of Online Youth Identity. In D. Buckingham (ed.), Youth, Identity, and Digital Media, Cambridge (Mass.): The MIT Press.

Hoggart, R. (1957). The Uses of Literacy: Aspects of Working-Class Life with Special Reference to Publications and Entertainments. London: Chatto and Windus.

Ito, M., Baumer, S., Bittanti, M., boyd, d., Cody, R., Herr-Stephenson, B., Horst, H. A., Lange, P. G., Mahendran, D., Martínez, K. Z., Pascoe, C. J., Perkel, D., Robinson, L., Sims, C. \& Tripp, L. (2010). Hanging Out, Messing Around, and Geeking Out: Kids Living and Learning with New Media. Cambridge (Mass.): MIT Press.

Jenkins, H. (2008). Convergence Culture. Where Old and New Media Collide (2 ${ }^{\text {nd }}$ edition). New York: New York University Press.

Kang, Y-Y., Wang, M-J. J. \& Lin, R. (2009). Usability evaluation of E-books. Displays, 30(2), 49-52.

Kaplan, A. M. \& Haenlein, M. (2010). Users of the world, unite! The challenges and opportunities of Social Media. Business Horizons, 53(1), 59-68.

Kress, G. (2003). Literacy in the New Media Age. London: Routledge.

Lankshear, C., Gee, J. P., Knobel, M. \& Searle, C. (2002). Changing Literacies. Philadelphia: Open University Press.

Lankshear, C. \& Knobel, M. (2003). New Literacies, Changing Knowledge, and Classroom Learning. Buckingham: Open University Press.

Lehtonen, M. (2001). Post scriptum. Kirja medioitumisen aikakaudella. Tampere: Vastapaino.

Lehtonen, M. \& Herkman, J. (2002). Next Stop: Multimodality. Report on the Multimodality and Culture Conference 8-9 June 2001 at the University of Tampere, Finland. Convergence: The Journal of Research into New Media Technologies, 8(4), 109-118.

Leppänen, S., Pitkänen-Huhta, A., Piirainen-Marsh, A., Nikula, T. \& Peuronen, S. (2009). Young people's translocal new media uses: a multiperspective analysis of language choice and heteroglossia. Journal of Computer-Mediated Communication 14(4).

Livingstone, S., Haddon, L., Görzig, A. \& Ólafsson, K. (with members of the EU Kids Online network) (2011). Risks and Safety on the Internet: The Perspective of European Children. Full Findings and Policy Implications from the EU Kids Online Survey of 9-16 year olds and Their Parents in 25 countries. London: London School of Economics and Political Science.

Luke, A. (1995). When Basic Skills and Information Processing Just Aren't Enough. Rethinking Reading in New Times. Teachers College Record, 97 (1), 95-115.

Matikainen, J. (2011). Yleisöjen sukupolvet - vastaanottajista tuottajiin?. In J. Matikainen (Ed.), Muuttuvat mediat - haasteelliset sukupolvet, Helsinki: Infor. 
NextMedia (2012). A Tivit Programme. http://www.nextmedia.fi. Accessed 12 March 2013.

Nielsen, J. (2006). How Little Do Users Read? Jakob Nielsen's Alertbox, http://www. useit.com/alertbox/percent-text-read.html. Accessed 10 December 2012.

Pagliassotti, D. (2008). Beyond the Book: Contemporary Cultures of Reading', Particip@tions 5: 2, http://www.participations.org/Volume\%205/Issue\%202/5_02_ editorial_special.htm. Accessed 15 January 2013.

Parlette, M. \& Howard, V. (2010). Pleasure Reading Among First-Year University Students. Evidence based library and information practice, 5(4), 53-69.

Pääjärvi, S. (Ed.) (2012). Children's Media Barometer 2011. Media Use among 7-11-year-old Children and Their Experiences of Media Education. Helsinki: Finnish Society on Media Education.

Prensky, M. (2001). Digital Natives, Digital Immigrants. On the Horizon, 9(5), http://www.marcprensky.com/writing/Prensky\%20-\%20Digital\%20Natives, \%20 Digital\%20Immigrants\%20-\%20Part1.pdf. Accessed 10 December 2012.

Radway, J. (1984). Reading the Romance. Chapel Hill: The University of North Carolina Press.

Ridell, S. (2011). Elämää Facebookin ihmemaassa. Tampere: Tampereen yliopisto/ CMT.

Rideout, V., Foehr, U. G. \& Roberts, D. F. (2010). Generation $M^{2}$ : Media in the Lives of 8-to 18-Year-Olds. The Henry J. Kaiser Family Foundation. http://www.kff.org/entmedia/upload/8010.pdf. Accessed 10 March 2013.

Sirkkunen, E. (2009). Aidattu vai avoin verkko? Omaehtoisen toiminnan muodot ja rajat sosiaalisen median tiloissa. In S. Ridell et al. (Eds.), Julkisen tilan poetiikkaa ja politiikkaa, Tampere: Tampere University Press.

Statistics Finland (2009). Ajankäyttötutkimus. http://www.stat.fi/til/akay/2009, Accessed 5 November 2012.

Statistics Finland (2011). Tieto- ja viestintätekniikan käyttö Suomessa 2010. http:// www.stat.fi/til/sutivi/index.html. Accessed 5 November 2012.

Statistics Finland (2012). Väestön tieto- ja viestintätekniikan käyttö 2012. http://www. tilastokeskus.fi/til/sutivi/2012/sutivi_2012_2012-11-07_tau_015_fi.html. Accessed 5 November 2012.

Stern, S. (2008). Producing Sites, Exploring Identities: Youth Online Authorship. In D. Buckingham (Ed.), Youth, Identity, and Digital Media. Cambridge (Mass.): The MIT Press.

Tapscott, D. (1998). Growing Up Digital: The Rise of the Net Generation. New York: McGraw-Hill.

Turkki, T., Siilasmaa, R., Ala-Pietilä, P., Baldauf, S. \& Lehti, M. (2009). Nykyaikaa etsimässä: Suomen digitaalinen tulevaisuus. Helsinki: Elinkeinoelämän Valtuuskunta, Taloustieto.

UCL (2008). University College London CIBER Project Information Behaviour of the Researcher of the Future: A CIBER briefing paper. (January 11, 2008). http://www. jisc.ac.uk/media/documents/programmes/reppres/gg_final_keynote_11012008.pdf. Accessed 10 December 2012.

Van Dijck, J. (2009). Users Like You? Theorizing Agency in User-Generated Content. Media, Culture \& Society, 31(1), 41-58. 
Weinreich, H., Obendorf, H., Herder, E. \& Mayer, M. (2008). Not Quite the Average: An Empirical Study of Web Use. ACM Transactions on the Web (TWEB), 2(1), Article 5.

Williams, R. (1963). The Long Revolution. Harmondsworth: Penguin Books. 


\title{
Reading in a changing society: Some examples of its impact in the Swedish context
}

\author{
Skans Kersti Nilsson
}

\begin{abstract}
Introduction
This study is based on two on-going research projects both financed by the Swedish Research Council; they are called Reading Fiction in the Internet Society: The Function of Literature in the Personal Development and Social Orientation of Young Adults, and The Case of the E-book in 'Small Language' Culture: Media Technology and the Digital Society. Both projects include research on reading. The former considers young adults, aged 16 to 25 , who have been brought up with the Internet and use digital reading for various purposes, and how this has affected their reading of fiction. The latter research project focuses on the uses of e-books today. As both projects are empirical, some of the same data has been used in both, but examined in different ways. In this article, statistics related mainly the E-books project is presented first; and thereafter a section from a focus-group interview carried out in the course of the Reading Fiction project is presented. Hopefully, together they will raise questions related to the current field of research - reading in a changing society.
\end{abstract}

\section{Statistics as background: reading fiction and non-fiction in print, digitally or in e-books}

A comparison of the results for PISA 2000 and PISA 2009 shows that the performance of Swedish students in reading has declined. The gender gap in reading performance has also widened in Sweden as the boys' reading performance has declined. In the OECD countries, the average percentage of students who said they read for enjoyment every day dropped by five percentage points, from $69 \%$ in 2000 to $64 \%$ in 2009 . On the other hand, Swedish students showed 
better results in digital reading performance than in the reading of printed texts. These changes have prompted questions for the politicians, teachers, librarians and researchers in our country.

Surveys on media use in Sweden, the national SOM Survey (Society, Opinion, Media) and the Nordicom Survey will be used to supplement the PISA results for this age group. According to the latest SOM survey, $87 \%$ of people between 15 and 29 years have read books - fiction or non-fiction - at some time during 2011. This is a decline of $2 \%$ since 2008 . Corresponding figures related to this category show that usage of the Internet has increased by 2 percent points, from $98 \%$ to $100 \%$, during the same time period (Höglund 2012). According to the latest Nordicom Survey for 2011, reading and listening to books is a daily activity for $36.7 \%$ of 15 - to 24 -year-olds. This breaks down as follows: $35.2 \%$ read printed books; $2.1 \%$ listen to books; and $0 \%$ read e-books (Facht 2012). Calculated as minutes per day, the data shows that an average of 20 minutes a day is spent reading books (boys spend 20 minutes and girls 33 minutes). The corresponding figure on the average use of the Internet as a daily activity is 179 minutes a day (boys 202 minutes or 3 hours 22 minutes; and girls 152 minutes, or 2 hours 32 minutes a day). (Nordicom-Sveriges Internetbarometer 2011; MedieNotiser nr 2, 2012) These supplementary figures reinforce the existing understanding that young adults in Sweden spend more time on the Internet than reading books.

The national 2012 SOM Survey posed questions on e-books and reading of e-books. An e-book is defined as follows: "an electronic version of a printed book which is intended to be read on a computer, a smartphone or other mobile reading device" (Bergström \& Höglund 2013). The results show that e-books are still read at a fairly low rate, but this has increased during the last few years.

Table 1. E-books reading in total, fiction and non-fiction (percentage)

\begin{tabular}{|l|c|c|c|}
\hline & $\begin{array}{l}\text { E-books in total } \\
(9 \%)\end{array}$ & $\begin{array}{l}\text { E-books non- } \\
\text { E-books fiction } \\
\text { fiction } \\
(\mathbf{5 \%})\end{array}$ \\
\hline Never & 91,4 & 93,7 & 95,2 \\
\hline Once during last 12 months & 2,5 & 2,2 & 1,2 \\
\hline Once during last half a year & 1,2 &, 9 &, 7 \\
\hline Once in four months & 1,2 &, 9 &, 8 \\
\hline Once a month & 1,4 & 1,1 &, 7 \\
\hline Once a week & 1,4 &, 7 &, 9 \\
\hline Several times a week & 1,0 &, 7 &, 5 \\
\hline
\end{tabular}

Source: The national 2012 SOM Survey (Bergström \& Höglund 2013) 
The data shows that equal percentages of fiction and non-fiction books are read in e-formats. E-reading differs according to age and education. To a certain extent this can be explained by the great shift in the acquisitions made by university libraries from printed books to e-books and e-journals.

Table 2. Relationship between the reading of printed books and e-books ( $\%$ of population)

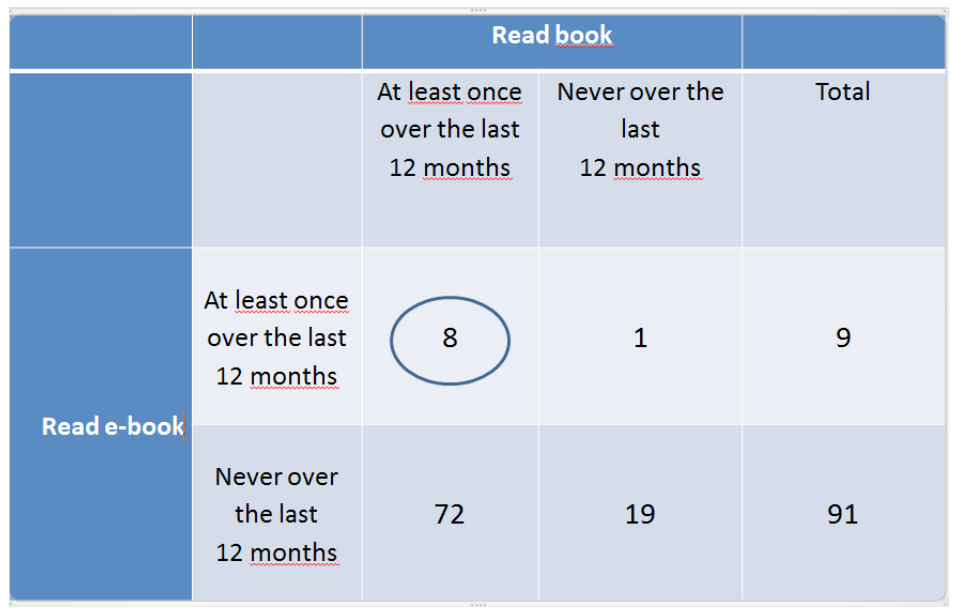

Source: The national 2012 SOM Survey (Bergström \& Höglund 2013)

Results show that there is a weak relationship between reading e-books and printed books. During the last year, the majority of the Swedes, about $80 \%$, has read a printed book, but not an e-book. Among the $9 \%$ who read an e-book last year, $8 \%$ had read both printed books and e-books. The percentage of those who read only e-books is negligible. Almost a fifth or $19 \%$ have not read any books at all during the last year.

New technologies and reading devices are changing reading and literacy. Questions related to the decline in literacy, the loss of deep-reading capacity, memory functions, cognition and knowledge-building in hierarchical structures, just to mention a few, are making reading research an expanding field within various disciplines, like pedagogy, didactics, literature, sociology, library and information science, digital humanities, media science, cognitive psychology and neurology. Research on reading is often multidisciplinary or interdisciplinary in nature, and is supplemented by transdisciplinary research for problems, such as 'embodied reading', that fall into the gaps between the disciplines, (Mangen \& Schilhab 2012). The questions arising from this are now related to the research. Technology may be more important to the reading process than expected (Mangen \& Kristiansen 2013). Mangen, Walgermo \& Brønnick 
(2013) show that students who read printed texts scored significantly higher on reading comprehension tests than students who read texts digitally.

\section{Reading fiction: the discussion among young adults in the focus groups}

Reading literature and narratives in printed books is at a crucial point today. Tempo, continuity and attention are required when reading literature in order to reach a certain level of absorption. As we have just seen, this activity is declining among young adults, who spend almost nine times more time on digital reading devices per day than on reading printed literature. The reading of literature is closely related to the cognitively demanding deep-reading process which, according to Maryanne Wolf (2009), is: “... the array of sophisticated processes that propel comprehension and that include inferential and deductive reasoning, analogical skills, critical analysis, reflection and insight." (Ibid: 131)

According to literary scholars and philosophers, the function of literature is to promote the expansion of empathy through reflections on characters (Keene 2007). Literature is also said to evoke narrative imagination and narrative identity (Ricoeur 1992, Nussbaum 1990). The reading of literature has also been found to be a basic cornerstone for democracy and good citizenship (Nussbaum 2010), and also to be related to the theory of mind, to our 'mind reading capacity' (Zunshine 2006). Finally, Rita Felski (2008) widens the perspective to include the ordinary uses of fiction. These theories are not based on empirical research. According to empirical studies on literature and media, comprehension and feelings are intertwined. Ordinary readers are likely to stay close to the text itself; their aim is to experience rather than to ask what the text might mean (Miall 2007: 36). The methodological approach to this study is multidisciplinary.

However, what about today's younger generation? Young adults are at a stage in life when their identities are being built psychologically and emotionally, as well as cognitively and socially. What do they think about reading literature? How do they relate to literature? What purpose does it serve and what meaning, if any, do they find in reading literature? Another question is what attitudes do young adults have towards reading literature in printed form or as digital text?

More specifically, this study aims to investigate the attitudes of young adults, based on their opinions and statements, towards reading literature and narratives; how the reading of literature and narratives relates to formats like printed books, e-books, digital reading on tablets; and whether there are any explicit characteristics of exchange related to reading literature and narratives in printed books.

The hypothesis is that today's young adults do not clearly show an interest in reading literature for personal development and social orientation, in printed books or digitally as e-books on reading tablets and other screen-based reading devices. 


\section{Method and materials}

The aims and questions are qualitative, as well as empirical by nature, and the method is based on interviews. The selected age group is at a very dynamic stage of development. Therefore, focus group interviews were chosen for studying both the means of communication - group-think, group-dynamics, language and expressions - and content. What thoughts, ideas, statements, old beliefs, or those newly constructed ones are revealed during the conversation? These two layers - communication and content - are intertwined in the results, as are the focus-group discussion practices (Marková et al, 2007: 72, Bergström $\&$ Boréus 2005). Theoretically, the philosophy of dialogue has a strong impact on the focus group interviews (Marková et al 2007). Conversations are dialogues between ways of thinking and cultural traditions (Ibid.: 25). According to Bakhtin, acts of speech are 'socially shared knowledge':

The work, like the rejoinder in dialogue, is oriented towards the response of the other (others), towards his/her active responsive understanding, which can assume various forms: educational influence on the readers, persuasion of them, critical responses, influence on the followers and successors, and so on. It can determine the others' responsive positions under the complex conditions of speech communication in a particular cultural sphere. (Bakhtin 1986: 75f)

The limited number of interviewees in the focus groups, i.e., 4 to 6 individuals, simplified the conversation and 'responsive understanding', leading to mutual understanding and consensus. Data was collected from nine focus groups, of which 30 respondents (16- to 19-year-olds) were studying various programmes at upper secondary school, and 15 respondents (19- to 25-year olds) were studying at the Folk High School. Of the 45 respondents, 28 were females and 17 males (Table 3).

Table 3. Categorisation of the respondents in reading study

\begin{tabular}{l|c|c|c}
\hline School/level & Female & Male & Total \\
\hline Theoretical classes, groups 1, 2,5 & 11 & 3 & 14 \\
\hline Practical classes, groups 6, 7, & 10 & 6 & 16 \\
\hline Folk High School groups 3, 4, 9 & 7 & 8 & 15 \\
\hline Total: 9 groups & 28 & 17 & 45 \\
\hline
\end{tabular}

The theoretical classes were comprised of group 1 and 2 (studying programme 'Global Future'), and group 5 (Aesthetic programme). The practical classes were comprised of group 6 (studying programmes 'Childcare' and 'Care and Welfare'), group 7 (studying programmes 'Media' and 'Graphic Communication'), and group 8 (studying programmes 'Graphic Design' and 'Building 
Technology'). Classes in the Folk High School were comprised of group 2 (Open programme 2nd year), group 3 and 9 (third year of the Open programme).

According to research ethics, participation was voluntary. This implies a bias within the results, as the majority of the respondents showed a positive interest in taking part in this study on reading literature and narratives. The respondents have also chosen nicknames (in italics) to prevent being identified.

\section{Results}

Not surprisingly, the statements on the daily reading of literature and narratives varied among the respondents within the groups, as well as between the groups and school levels. More interesting is the fact that the attitudes towards reading literature are clear among the majority, irrespective of whether they were avid readers, moderate readers or non-readers.

\section{The attitudes toward reading literature and narratives revealed by the opinions and statements}

\section{Theoretical classes}

Students in the theoretical classes were mostly convinced of the importance of reading literature in general, although the respondents in the group 2 preferred reading narratives based on reality and regarded them as more useful. For Adam, language is of greatest importance for the reading experience. Respondents in the group 5 believed that reading actually has an impact on empathy and judgements. For Leslie, permission to read literature is very important: "To feel, that I can read anything I want to; that I am not trapped within myself, so to speak. Having access to the imagination of others is very important." Like group 5, group 1 also mostly related reading literature and narratives to fiction. The conversation holds on to relaxation and physical wellbeing, given that reading is not forced or under stress. This is very sensible aspect of motivation, which differs from other characteristics like 'reading is voluntary and open-minded'. Classics like Crime and Punishment, which belong to general knowledge, are difficult and even boring to read, but in the end, were found to be something that one could be proud of and one that also impressed others. Some referred to peculiar experiences that might occur. Ullis described her personal experiences as an avid reader. She spread books all over the house to her parents' annoyance, and was absorbed in reading at the dinner table: "If it's a really good book, I don't hear them talking to me. I make funny faces based on what I read, and the rest of the family laughs at this." She said that she never gives up on a book. Reading books is, according to Ullis, a 'threshold' to thoughts and imagination. 


\section{Practical classes}

The conversation in the practical classes made note of the differences in reading; for example, when it was part of the school curriculum and thereby 'forced', or when reading was voluntary. These differences in reading strategies and their outcome were important to the respondents in group 6 . Whether books are interesting or boring is certainly more important than whether one reads fiction or facts. Other criteria were "thrilling" (Nadja) and "time-killing" (Rasmus). The language also has to be related to the content in order to maintain the atmosphere. The discussion in group 7 was highly influenced by Nathalie, an avid reader, who believes that one should give all kinds of literature "a chance". She emphasised that reading improves imagination, like, "Aaah, that's a smart idea". Reading also improves your language, she believes. The following statement was made by Erik, who thinks that language and vocabulary develop from reading literature: "It makes you grow very much as a person. [...] You seldom regret anything you've read." In group 8, Karl, who had a strong impact on the discussion, talked about absorption and concentration in reading literature. Karl achieves this through reading books and listening to music at the same time. This calms his nerves and helps him get close to himself, and not be disturbed by others. Language is of the greatest importance, he said, as you have to reach out for understanding. Karl competes in sports. He is well aware of his personal self, picking and choosing the things that help him achieve his goals and shape his identity. Reading literature is one such choice. Reading activates your imagination creating pictures that will be connected to that book for as long as you live, he said.

\section{Folk High School}

Students at the Folk High School believed that narratives affect and arouse emotions, as they are long and full of details. Narratives are related to "good books". The consensus in group 9 was that reading fiction improves imagination and personal language proficiency, oral as well as written. The respondents also discussed their identification with fictional characters as an ethical topic identification for good or bad. Young adults that lack self-confidence and life experience, and therefore are less able to separate fiction from fact, easily identify with "the bad guy," Annika stated. She and Halfdan were convinced that mass murderers, like Anders Bering Breivik, have lost themselves in fictional violence. Ronny, on the other hand, believed that the compassionate emotions acquired from reading fiction can turn in a positive direction: "If you start taking drugs, you can replace the drugs with a book. That's how strong it is." Lisa, who prefers reading non-fiction, said that narratives based on reality are not suggestive because they describe what has actually happened. One cannot add anything to it, as one can with fiction.

The males in group 4 did not like to read crime fiction or science fiction, as they felt it is violent and repetitive. Bertil and Daniel agreed that reading fiction 
develops one's imagination and mental capacity, but Clark and Cissi, who do not read much, did not share this experience. Bertil talked about his recursive experience when reading his favourite book, Nils Holgerssons underbara resa by Selma Lagerlöf. He still experiences the same positive emotions that he did when his parents read the book aloud to him as a child.

In group 3 the dynamics of the discussion were focused on Ulf and Anna. Anna is an avid reader like the rest of her family, who have introduced her to classics like William Shakespeare. Anna and Ulf emphasised personal choice as being important to the reading experience. All the respondents related reading with affection and stressed the importance of picture-images when reading fiction. Eva described a good read as being like "listening to one's own voice". These statements were recurrent. Ulf described reading fiction as taking an active part in a creative process: "You can easily identify with the main fictional character, because the story is not talking about a real person." The reading of narratives caused the reader to reflect on life as well as on oneself. To Anna, reading has given her the strength to think about new paths in life.

\section{How is reading literature and narratives related to formats like printed books, e-books, digital reading on tablets?}

\section{Theoretical classes}

The attitudes towards reading literature on the Internet were not clearly evidenced in the theoretical classes. Adam, in group 2, found advantages in both. He has anonymous friends on the Internet who share his interests in books and reading: "Often when you read an anonymous discussion you find a lot of books and you can also give recommendations to others." Adam believes printed books to be the best format for narratives, though he doesn't have time to read very much. Instead he reads fiction on the Internet - short stories that do not demand patience, mostly horror or other peculiar stories which create new images or metaphors. Adam calls them 'sticks'. However, he said that printed books are the format best suited to mediating narratives, and taking control of the reader's experience. His personal favourite is a minor Swedish classic, Röde orm (1941; 1945) by Frans. G. Bengtsson (1894-1953), which he loves to read because of its beautiful language. "Like poetry," he said. Digital literature on the Internet is much shorter, and therefore, the message is compressed. However, it is still a narrative built on text - a universe created in detail by the author. Otherwise, he said, printed and digital texts are much more alike than books and films. Nilla found that, when reading on online, she was not as focused as when she read printed books. Maybe, because you can do so many things simultaneously on the Internet, she said. Books are tactile, something you hold in your hands, something special. Berit has downloaded books that she could not get at the library, but was eager to read, on her iPhone. But, she said, digital reading puts a great strain on her eyes, making her so tired and 
exhausted that you gives up reading and forgets all about. A printed book is something very different, she said. You can sit and turn the pages; it is much easier, so you can read for much longer periods. Cilla said the following:

I'd like to say that it is the book itself... sitting and holding it...It has to do with the experience. When you read a book and look at the cover in front of you... this improves the atmosphere as compared to reading on an iPad. I have tried it, but it does not give the same affect at all. It's too stiff.

Group 5 was comprised of students studying Aesthetics. They don't believe there's any difference in reading printed or digital texts, but reading digital books on screen is too exhausting, and not as comfortable as reading printed books. Florence remembers when she younger and participated in an Internet forum on stories and books. "You wrote or added something for others to comment on, and then you added something more to continue. These stories or threads became extremely long, but suddenly they were put aside." She found this quite interesting and an experience you never find in libraries.

Students in the practical classes do not think that digital reading is as deeply engrossing as reading texts on paper. Emelie in group 7 said that the constant interruptions for ads was distracting, something that doesn't happen when you're reading books. It is easier to become engrossed in books. Margareta agreed: "When you open a book, it's only what it says that matters; there's no technology or anything, and this is very special." Nathalie agreed. "All the terrible things going on in the world; all the stress that surrounds daily life makes it so nice to sit on a sofa and get engrossed in a book that doesn't have anything to do with reality," she says. To rid oneself of the stress for while is really nice, she says. Erik pointed out the differences between reading social media and reading printed books. It is obvious, he said, that you have different approaches to reading:

When I read a book I have the approach of reading a book, it is not the same with social media. I just don't focus my attention like when I'm reading ... I just don't think about it. But you experience more than you expect. On Facebook you can find quite a lot of poetry, but you never think about it as poetry. It's just being on Facebook.

Margareta suggested that one should have the choice of reading all school materials in digital formats. This statement split the group into opposing camps. Krister thought that digital reading belongs in today's schools, but Emelie was negative - she felt that reading texts is nicer and more charming. However, nobody in this group had ever read e-books. The students in group 8 were also not interested in reading e-books. None had ever tried or had any interest in trying. Karl thought of reading printed books as nice: “... books have charm... and there is already enough computer-reading ...I would never read a book in that way... but of course, tablets provide access to many books... there are always advantages..." Other respondents pointed at the physical and cognitive disadvantages of digital reading - fatigue and tired eyes, lack of concentration 
and focus, which result from the many options on the Internet. Lina agreed with Karl: "There is a charm to holding a book in your hands while reading. This is the big plus with books."

\section{Folk High School}

Discussions on these topics among focus groups in Folk High School stressed the different outcomes and benefits of reading in different formats. Ulf in group 3 found that reading printed books, unlike digital reading, forms a personal experience. He admitted that he has never bought or borrowed e-books, but has tried reading them. He found it difficult to concentrate on longer texts when reading them on-screen. Anna agreed. Her eyes were affected, something she is afraid of. Anna was very aware of the sensuous experience provided by books and reading, like the smell of the book, the tactile experience of holding it in your hands, and turning the pages "which make reading printed books more physical". Eivor and Eva both agreed that it is hard to concentrate when reading digitally.

Clark in group 4 said that the digitalisation of cultural heritage is important. But for everyday reading, there is nothing compared to reading printed books, he added. The sensuous experiences from this physical object cannot be replaced by a digital context. He has actually tried reading fiction on a tablet: "I didn't get the same feeling of peace. On the tablet, I read maybe three pages of a book that I would have read all the way through if I had it in my hands." Clark focused on another side of the issue - people with reading disabilities who might get help from technical support, like the pronunciation of words. However, his personal standpoint is that printed books written are much nicer to read. All respondents in the group agreed with Clark's statements.

\section{Are there any explicit benefits from reading literature and narratives in printed books?}

\section{Theoretical classes}

According to the respondents, reading literature is a linguistic exercise related exclusively to physical books. Books are associated with sensuous experiences that surround the content. The reading of literature was considered to be a freely chosen action. It is closely connected to intimacy. Therefore, digital reading is related to other activities and other purposes.

According to Ullis (group 1), the explicit benefits of reading literature are that your brain is stimulated all the time, and focuses on historical and anthropological outlooks: "Narration is part of humanity," she said. "Narratives are passing on to new generations; it makes you aware of own culture as well as the cultures of others. It is a way to preserve humankind." On the other hand, Linus thought that literature brings rationality and knowledge to the reader: "It is enlightenment; it provides perspectives on things; judgements." Another issue is language. According to Eva, developing your language opens doors to new worlds. Cilla and Eva believe that reading literature is also a way to use 
creativity. It is easier to understand other people's life situations through narratives than from news articles.

Adam, in group 2, used metaphors like 'investment' and 'control' when describing the personal engagement with fiction. He found that reading books requires a greater investment than watching films: "A good book is a better experience than a good film, but it's much worse to read a bad book than to watch a bad film." Nilla found that reading time is a time for being alone and valuing yourself. Adam believes that:

... awareness of other people is a benefit of reading literature. People live different lives, people get sick. Literature talks about that the things that are not self-evident. Literature that makes you think is what I like best. To think of something you've never thought of before, means that you are learning from literature.

Nilla and Cilla agreed that a good book can affect you for a long time afterwards. They believe that good reading makes you feel like you're inside a bubble. This metaphor speaks to embodiment. You are alone, and yet you are not alone.

\section{Practical classes}

The groups in the practical classes responded to this question in a more focused way. Rasmus, a boy in group 6 who does not read very much, provided this summary, which was appreciated by the whole group:

When reading a book you get your own thoughts and then it turns into silence; this makes you think of the story in the book and what is happening to you when you are reading. At least that's what happened to me when reading; I suddenly stopped and started thinking about myself and what I was actually doing.

Nathalie in group 7 concluded that:

The greatest benefit, I believe, is imagination. Your imagination will always belong to you. Today, everyone can get to know you through social media; somebody knows something about someone else, and you can get schoolwork and other things that others have done. But your imagination will always be your own. You can always create new fantasies and I feel that your imagination that will be yours forever and not someone else's. Nobody can take it away from you. Ever.

For Karl, in group 8, reading literature detaches him from the surrounding world. It gives him peace of mind.

\section{Folk High School}

In group 3 at Folk High School, Anna and Ulf elaborated this question. Ulf referred to what he has said before: 
I am always painting pictures in my mind when I read. It is creative and stimulating to read a book. It exercises your brain. You have to create pictures. I believe everybody does this when reading. You create pictures in your brain to see what is happening. The brain needs to be used. This is what it's meant for. Reading is the most natural entertainment. Somebody has written a mystery and you put the pieces together. You exercise your brain by reading.

Ulf found neurological and cognitive benefits from reading printed books. Anna, on the other hand, said that:

The difference between reality-based narratives and fiction is that fiction gives answers to things that might be possible, beyond reality... so if something happens in real life, these fictional solutions can help to make the proper choices ... you get a flashback from you've read, all you've seem which makes you think: What would I do? Who am I as a person? This is what fiction gives you: possibilities that are not real... Reading fiction gives me self-confidence, and better thoughts about myself.

Anna's personal benefits from reading printed books are social, environmental and psychological, which altogether help to shape her life.

\section{Analysis and discussion}

Reading literature - fiction, as well as non-fiction narratives - is an activity that is decreasing among young adults. Statistics show that using the Internet, and thereby digital reading, is generally a more frequent daily activity. Sweden, a small language culture, is vulnerable to changes in habits and media consumption. The E-books project is focused on what an expected expansion of e-books on the Swedish book market, and thereby e-book reading, could cause.

The focus group study was aimed at examining the attitudes of young adults in conversations comparing the reading of literature in print or digital formats, but also on what special benefits, if any, they find in reading printed books. The questions were not focused on literature itself, as an object or preferences of genres, or on tastes in literature based on sociological, demographic categories like age, gender and class. The categories in this study were the theoretical and practical classes, as well as classes in Folk High School, that covered a broad range of young adults, aged 16 to 25 . The three main questions of this study focused on reading experiences.

According to the limited sample in this study, young adults have a positive attitude towards reading literature and narratives. Narratives seem to arouse emotions, which are produced by written language and which makes readers "listen to their own voice" and "create pictures in their minds". These statements were recurrent. Books, as physical objects, activate all the senses by combining format 
and content. A printed book is tactile or haptic - you can hold it in your hands, smell it, turn the pages, and look at the inside and the outside. These thoughts were frequently repeated in the study. Phenomenological approaches speak of physical experiences as embodiment. Today, the phenomenology of reading in different formats has been found to result in different in multi-sensory engagement (Mangen \& Schilhab 2012), but the field still has to be explored by multiand interdisciplinary research. The capacity for 'deep reading', as defined by Maryanne Wolf (above), in different formats is a significant question today, as is its effect on memory. Respondents in this study not only demonstrated an awareness of the differences in comprehension when reading different formats, but also of the different uses of reading materials and modes of reading. According to this study, reading literature, fiction and non-fictional narratives, is closely related to printed books or texts on paper. Liu (2005) concludes that "of the preference of people for paper as a medium of reading (especially in-depth reading) also implies that paper is unlikely to disappear in the digital age." The results of this study show that the spontaneous response to reading literature is identified with printed books and most often with in-depth reading. Only in one exceptional case was reading literature in digital formats found to be usual. The lengths of the texts are an important criterion. When it comes to the preferences related to reading literature in printed books or digital formats, we see that that reading literature and fiction is, without exception, related to printed books. It is believed to be a process of internalisation. These experiences are also found to affect memory, which does not occur with digital reading, except with very short texts. Based on this study, there is no interest in reading literature in digital formats. It turns out that books, as artefacts, are not threatened by e-books or other digital narratives. The result of this study confirms the results from the latest Nordicom Survey (Facht 2012).

This study shows that absorption through identification and imagination is important to the attitudes and experiences of young adults related to reading literature. Imagination is mainly stimulated by reading fiction and found to be important for preserving one's self but also for expanding one's self. Maurice Merleau-Ponty (1962) describes works of art as individuals whose meaning are "accessible only through direct contact, being radiated with no change of their temporal or spatial situation" (1962: 151). Further, the phenomenology of reading is described as "not only understand(ing) but even feel(ing) what I read" (Poulet 1969). According to Mikhail Bakhtin in his theory of chronotope, correlations between time and space produce awareness, intensity and meaning (1981). In the focus group interviews, the philosophy of dialogue is a useful tool for describing the involvement and engagement between one text and another (intertextuality), between a text and the reader, as well as, between one reader and another.

Reading narratives, fiction as well as non-fiction, was found to be a creative activity. Respondents found that reading narratives was beneficial since it meant taking part in a self-reflective activity, a position that Ricoeur (1992) 
calls 'narrative identity' and Martha Nussbaum 'narrative imagination' (1997). The reading of literature activates introversion and self-confirmation. Choice is a part of identity and reading shapes that identity. It was also found to be an expansion of self. Fiction, more than narrative non-fiction, is understood to develop imagination. Further, the benefits of reading literature in printed texts include the support of emotions, self-reflexivity, judgement, imagination, shaping of identity and improvement of language. These characteristics are expressed in the conversations with the focus groups.

At the meta-level, reading fiction is an idea, a concept or metaphor for something positive, something good and helpful to the individual as well as to society. Conversations on these topics in small groups have several benefits. Listening to others in a concentrated way, the associations and reflections of oneself improve one's respect and knowledge towards oneself and others (Ricoeur 1992).

The conclusion is that the hypothesis, which states that today's young adults do not show any explicit interest in reading literature for personal development and social orientation, either in books or digitally as e-books on reading tablets or other screen-based reading devices, does not corresponding with the findings of the study.

\section{References}

Bakhtin, M. (1981). The Dialogic Imagination: four essays. Austin: Univ. of Texas Press.

Bakhtin, M. (1986). Speech genres and other late essays. Austin, Univ. of Texas Press.

Bergström, A. \& Höglund, L. (2013). Tidiga läsare av e-böcker. In L. Weibull, H. Oscarsson \& A. Bergström (Eds.), Vägskäl. Göteborg: SOM-institutet.

Bergström, G. \& Boréus, K. (2005). Textens mening och makt: metodbok i samhällsvetenskaplig text- och diskursanalys. 2., omarb. uppl. Lund: Studentlitteratur.

Facht, U. (2012). Aktuell statistik om E-böcker: sammanställd av Ulrika Facht. www.nordicom.gu.se/mediesverige

Felski, R. (2008). Uses of fiction. Malden: Blackwell.

Höglund, L. (2012). Bibliotek, sociala medier och digital delaktighet. In A. Bergström, L. Weibull \& H. Oscarsson (Eds.), I framtidens skugga. Göteborgs universitet: SOM-institutet.

Keene, S. (2007). Empathy and the novel. Oxford: Oxford University Press.

Liu, Z. (2005). Reading behavior in the digital environment. Changes in reading behavior over the past ten years. Journal of Documentation, 61(6), 700-712.

Mangen, A. \& Schilhab, T. (2012). An embodies view of reading: Theoretical considerations, empirical findings, and educational implications. In S. Matre \& A. Skaftun (Eds.), Skriv! Les! Trondheim: Akademika forlag.

Mangen, A., Walgermo, B., \& Brønnick, K. (2013). Reading linear texts on paper versus computer screen: Effects on reading comprehension. Journal of Educational Research, 58, 61-68. 
Marková, I., Linell, P., Grossen, M. \& Salazar Orvig, M. (2007). Dialogue in focus groups: Exploring socially shared knowledge. London: Equinox Publishing.

Miall, D.S. (2006). Literary reading: empirical and theoretical studies. New York: Lang.

Nussbaum, M. (1990). Love's knowledge: essays in philosophy and literature. New York: Oxford University Press.

Nussbaum, M. (1997). Cultivating humanity: a classical defense of reform in liberal education. Cambridge Mass.: Harvard University Press.

Nussbaum, M. (2010). Not for profit: why democracy needs the humanities. Princeton, N.J.: Princeton University Press.

OECD (2010). PISA 2009 Results: Executive Summary. http:// www.oecd.org/pisa/pisaproducts/46619703.pdf

Poulet, G. (1969). Phenomenology of reading. New Literary History, 1(1), 53-68.

Ricoeur, P. (1992). Oneself as another. Chicago: University of Chicago Press.

Wolf, M. \& Birizali, M. (2009). The importance of deep reading. In M. Scherer (Ed.), Challenging the whole child: Reflections on the best practices in learning - teaching - and leadership. Alexandria, VA: ASCD.

Zunshine, L. (2006). Why we read fiction: Theory of mind and the novel. Columbus, $\mathrm{OH}$ : Ohio State University Press. 


\title{
Reading policy and public libraries in Estonia - from the perspective of the Foucauldian analytics of governmentality
}

\author{
Krista Lepik
}

\section{Introduction}

Two years ago, as a result of a speech by the Minister of Culture during Library Days (Lang 2011), the Estonian news media filled with reports on probably one of the greatest debates related to the extent that the state, or the Ministry of Culture, should or could influence the acquisition principles of public libraries in Estonia. Until that time, the public libraries had been relatively independent when deciding matters related to acquisition. Decisions were made based on the Guidelines on the Work Principles of Public Libraries ("Rahvaraamatukogu töökorralduse juhend") and, to a great extent, based on the topics and issues that were seen as relevant for the library users. However, the Minister of Culture suggested that the funds provided by the state for the acquisition of books should be used to buy or order quality books and periodicals that are important from the perspective of Estonian national culture. This idea, which aimed to protect Estonian national culture and popularize quality literature, was soon implemented in public libraries. Since 2012, Estonian public libraries must firstly acquire quality literature based on the "List of Prizewinning Books and Cultural Periodical Publications by Estonian Authors” („Eesti autorite auhinnatud teoste ja kultuuriajakirjanduse loetelu“", see Linkgreim 2012 for the list), regardless of whether the library users are interested in this type of literature or not, or whether the library needs to provide access to other kinds information besides quality Estonian literature (Holm 2012).

Although the aforementioned changes in Estonia's 'reading policy' took place two years ago, the relevance of the debate related to the role of Estonia's public libraries has not decreased over time. Instead, a certain 'maturing' of these changes has occurred over time, which allows us to take an analytical 
look back at the earlier situation and the possible developments. The point of departure for this paper is the principles of the Foucauldian analytics of governmentality, and discusses the interested parties possibly affected by the aforementioned decisions regarding 'reading-policy' and how the roles of these interested parties could change in the light of such 'reading-policies'. Therefore the paper focuses on the constellation comprised of the ministry, the public library and the reader, and asks to what extent state-level intervention is necessary in such a private or even intimate relationship as the one between a reader and a book. Despite the emphasis on the debate related to public libraries in the introduction, the aim of this paper is not to analyse this debate on the role of the public libraries, but rather to introduce an analytical tool to study the relationships between public libraries and particular stakeholders (the ministry and the library users), by employing the aforementioned debate to exemplify a possible path of analysis.

\section{The analysis of the government as a tool for analysing the interested parties related to reading policy}

First of all: what is governmentality and what is meant by the analysis of government? One might assume that both of these ideas are related to an inquiry of the workings of governmental institutions. However, this is not the case. In the Foucauldian approach, government is defined as an "ensemble formed by institutions, procedures, analyses and reflections, calculations and tactics that allow the exercise of this very specific, albeit very complex, power that has the population as its target" (Foucault [1978] 2007: 108). For those who are somewhat familiar with Foucault's theories, his approach to governance should immediately be differentiated from his work related to disciplining, as governance functions in alignment with the so-called 'new pastoral power' (Foucault 1983 ) - providing those who are governed with certain well-being, involving a variety of institutions, and considering "the development of the people, both as a population and as individuals" (Lepik 2013: 21). To sum up, the government "is a more or less calculated and rational activity, undertaken by a multiplicity of authorities and agencies, employing a variety of techniques and forms of knowledge, that seeks to shape conduct by working through our desires, aspirations, interests and beliefs, for definite but shifting ends, and with a diverse set of relatively unpredictable consequences, effects and outcomes." (Dean 1999: 11).

The analysis of government, while dealing with this set of topics, aims to focus on power relations, not by asking classical critical questions on the sources of rule or basis of its legitimacy (Dean 1999: 29), but rather by asking the 'how' questions related to the ways of government and possible ways of resistance "that reveal possibilities for doing things otherwise" (Dean 1999: 
37). To find the answers to these kinds of 'how' questions related to governance in libraries, the analysis of the articulations used to govern library and museum visitors has been found to be useful elsewhere (Lepik 2013).

In Lepik (2013), the idea of ideology has been treated as a conceptual bridge between the encompassing concept of governmentality (in diverse walks of life) on one hand, and libraries and museums on the other - as types of institutions that produce and maintain ideologies. According to previous studies (Lepik 2013, Lepik \& Carpentier 2013), the articulations provide libraries, but also museums, with a relatively diverse set of possibilities for governing the visitors based on certain ideologies and in accordance with certain discourses. The repertoire of governance ranges from disciplining to categorising, exclusion and incorporation (into the activities of the institution), and the various modes of government can possibly be countered by forms of resistance, ways for doing otherwise.

From the perspective of this paper, the aforementioned debate on the need for nationally established compulsory literature lists is a particularly vivid example of 'possibilities for doing things otherwise'. Although the debate itself is already history, its emergence has helped to point to the different interested parties related to the discussion of the role of the public library, the position of the readers - or the users of public libraries, to be precise. However, identifying the various interested parties related to the governmentality of reading establishes a starting point for further analysis.

\section{Reading policies as a means of governing the population of readers}

In terms of governance analysis, the reading policies that are implemented by governmental institutions in various countries can be seen as means of arriving at certain shifting ends, based on the development of the governed population. Reading policies as a means of government may be closely associated to the eradication of illiteracy in certain populations (McDaniel, Sims \& Miskel 2001). Yet, this is not the case in Estonia where over $99.5 \%$ of the population is literate. An important aim in the governance of the potential population of readers can also be to generate enthusiasm about reading when the interest in reading seems to be decreasing despite the high literacy rate (Koren 2009). This is an important aim in the governance of the potential population of readers, which is also included in the document that establishes Estonian cultural policy until 2020 (Kultuuripoliitika põhialused aastani 2020). Moreover, as Estonia is a small country with a small population, the importance of supporting the national culture and popularizing the works of Estonian authors has been seen one of the aims of the Ministry of Culture within the framework of the Estonian cultural policy. 
However, until the debate was started by the Minister of Culture, Estonian public libraries played a somewhat less prominent role in the fulfilment of these national goals. Although introducing literature on national culture and Estonian identity (Rahvaraamatukogu töökorralduse juhend) has been prioritized, the materials that address the basic needs of the library users have also been taken into consideration (Ibid.). The written cultural heritage is preserved by the National Library of Estonia and the libraries that functions as archives. Some support has been provided to Estonian authors by the Grant Programme for Estonian Literature (Eesti kirjanduse toetusprogramm). The basic functions of the public libraries in Estonia have been based on different traditions related to reading policy, and have only relatively recently become focused on national cultural policy.

\section{The basic values guiding work in public libraries}

The aforementioned debate on the role of the public library has most probably fostered a clear outlining of the basic values of Estonian public libraries (the guidelines for their basic functions). The librarians themselves have considered public libraries to be remarkably neutral institutions: during the years of Estonia's re-established independence, public libraries have remained outside the political debates, enabling their visitors the access information without setting limits on the users or the information provided to them. They have publically distanced themselves from their previous ideological duties (e.g. Valm 2002; Sepp 2002). In principle, the UNESCO Public Library Manifesto and Estonian Code of Ethics for Librarians and Information Professionals have played a prominent role in cultivating the values cherished by professionals working in Estonian public libraries and still do. On the one hand, these documents tap into the importance of "free and unlimited access to knowledge, thought, culture and information" (UNESCO Public Library Manifesto 1994); while on the other hand, the need for the best possible "neutral service" is emphasised (Eetikakoodeks 2001). It is important to stress that these documents still form the basis for the librarians' ideals of neutrality, and these values are also taught to library and information science students - to future librarians. However, after the debates and changes that occurred two years ago, the neutrality of Estonian public libraries is not taken for granted as much as it used to be.

The role of public libraries is changing (be it providing various traditional information products and services, acting as a meeting place, or enabling various forms of cultural participation in the society). This is a cliché, and there is nothing new about the changing roles of libraries, if we recall Ranganathan's Fifth Law of Library Science, i.e. "The library is a growing organism". Thus, change $i s$ essential to libraries, including public libraries. Yet these changes are 
related not to just novel or outdated tasks or activities, these roles are much more fundamental, touching the basic working principles of public libraries.

\section{The role of public libraries within the framework of reading policies}

When analysing the national reading policy in Estonia, the attention focused on public libraries can primarily be explained by the sphere of influence in which public libraries operate (Lepik 2013). In addition to being partly funded by the Ministry of Culture (and partly by the local municipality where the public library is located), public libraries, unlike other types of libraries, are deemed to have an influence on the book choices of (adult) readers who visit public libraries. Other types of libraries (research libraries, school libraries) fulfil different purposes - the corresponding ministries do not have such a direct impact on acquisition policies or their influence is hardly noticeable in the acquisition principles of the libraries.

Secondly, this paper is not focused on situations where the readers (who are not necessarily library users) choose reading materials for their personal libraries - by visiting bookstores or antique shops, publisher's outlets or websites, online book shops, etc. The national reading policy can exert some pressure on these readers (via publishers or public libraries), but home libraries remain beyond its reach.

Stressing the need to analyse public libraries in particular, the third reason can be found in the studies focused on reading (e.g. Lauristin 2013). Compared to 30 years ago, the number of people buying books has decreased dramatically. Compared to 20 years ago, the size of home libraries has also decreased drastically. Yet, the number of people who regularly or sometimes read fiction, for example, has not decreased at quite the same pace. This observation allows us to assume that, to some extent, public libraries in particular may still play an important role in fostering their users' reading habits. This assumption is also supported by the statistical data from Statistics Estonia, which shows that the average number of loans per public library user has been increasing (from 21.4 loans in 1992 to 30.5 loans in 2012) even while the total number of visitors to public libraries has been decreasing (see Figure 1). 
Visitors to public libraries compared to average number of loans per visitor

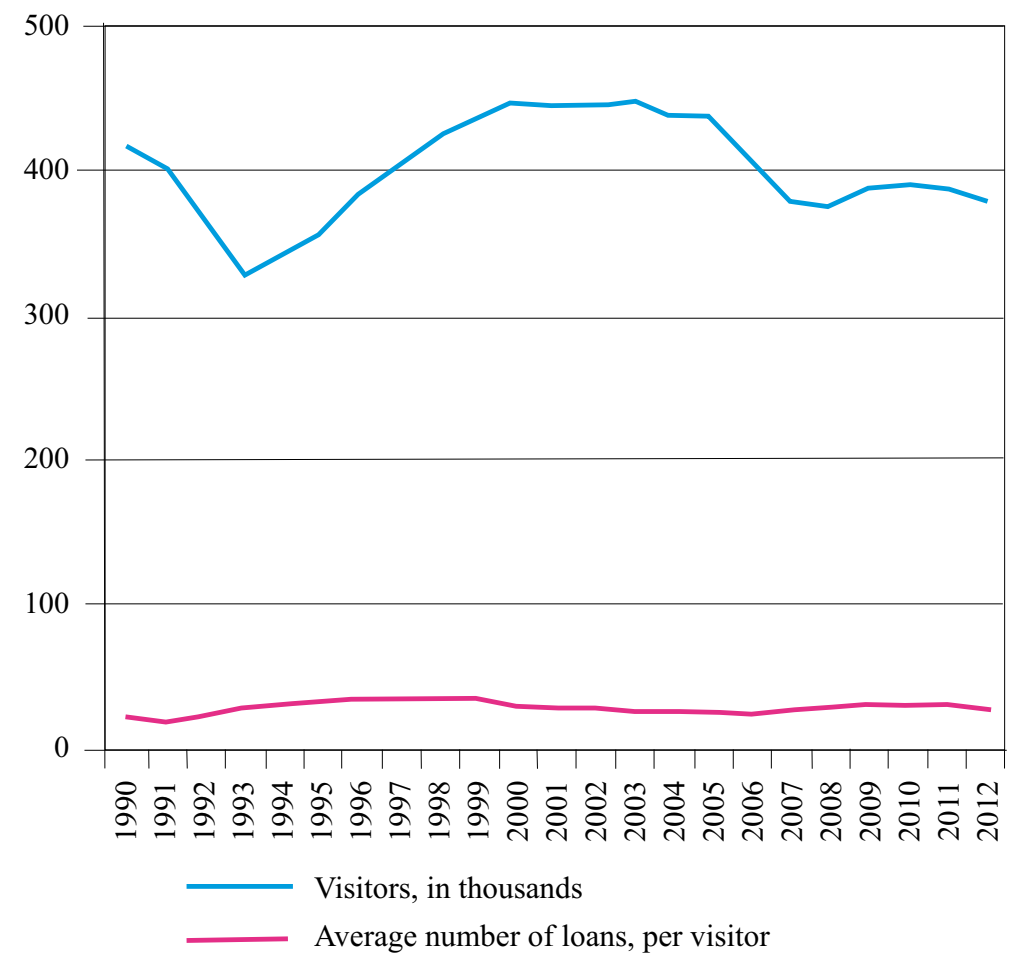

Figure 1. Visitors to public libraries compared to the average number of loans per visitor.

Source: Statistics Estonia

\section{The role of public libraries beyond the reading policies - the changing roles of librarians and public libraries}

So far in this paper, the fostering of reading habits has been discussed as a 'topdown' process, however by doing so there is a danger that the societal position of the public library will be left out of the analysis of the relationship between public libraries and their users. Nowadays, the public library is not only an institution that fosters reading habits. It is much more than an institution that just supports access to information, as its tasks include diverse activities that support the life of its surrounding community. Especially under circumstances, (especially in rural areas) where the public library might be the only (state) 
institution creating affordances that do something worthy or interesting, the ability to offer more than just printed materials across the service desk is crucial. Public libraries are meeting places which support learning - both informal and lifelong learning - and social life in the community. They have the potential to provide knowledge and various skills to help its users cope in an information society (Holm 2013).

As the role of the public library has diversified, the role of the librarian has also expanded. In addition to their traditional tasks (serving readers' interests, improving the library's collections, etc.), the librarians in public libraries also act as 'teachers', 'psychologists', 'social workers', etc. Considering the plurality of their roles, the question arises: Can we consider public libraries to be tools for the top-down implementation of national policy or are the roles of the public library increasingly influenced by its ability to establish a dialogue with its users - starting with listening to what the users have to say about their information needs, and other library-related interests. There is never too much visitors' interest, nor too many diverse interests in a public library. However, the question could be whether the public library can meet those diverse interests without finding itself in the middle of conflicting interests?

\section{The conflicting interests of the reader and the library}

The studies about cultural participation (e.g. Lauristin \& Lõhmus 2010, Lõhmus, Lauristin \& Siirman 2009) have pointed to very diverse reading preferences. In particular, the interest in quality fiction is complemented by an interest in non-fiction that broadens the mind (books about nature or history, for example), an interest in hobby- or work-related books, and an interest in entertaining literature (Lauristin \& Lõhmus 2010). Moreover, these interests can be treated in combination: "the interest in home and family-centred 'how-to' literature" combined with "light reading" (Lõhmus, Lauristin \& Siirman 2009: 81), "an interest in history and nature [...] combined with various reference books" (Ibid. 81), a general interest in different kinds of fiction, etc. Such a complexity of interests is questioning the afore-mentioned reading policy, which reduces diverse reading interests into specific interest group. Therefore, by satisfying the users' reading needs and interests public libraries act as a meeting point for two important principles: the promotion of quality books (fiction, periodicals) on the one hand, and the users' personal reading interests on the other, which can, but do not necessarily, include literature that can be called 'quality literature' based on certain criteria (Carpentier 2013).

We can compare these two principles based on the history of two prominent types of public libraries: the American public library and German 
Volksbibliothek ('peoples' library'). In short, the American public library is characterized by free access to and unlimited availability of literature (Volodin 2005), and "absolute neutrality" (Volodin 2005: 211) in meeting the personal interests that bring the users to the library. At the same time, the German public library type, based on the ideas of Volkspädagogik, supports "offering the reader only 'good' literature" (Volodin 2005: 214), that is, offering only quality literature. These two public library types are not necessarily contradictory as the reader may have a serious interest in publicly acknowledged quality literature (as has been shown by Lauristin \& Lõhmus 2010).

Nevertheless, these two public library types involve important differences from the perspective of an analysis of government. In the American public library, the reader does not need the librarian's guidance or intervention when choosing literature, since it is assumed that the readers can choose their own literature. In the German public library, which has historically been intended for people from very different social strata, the librarian is expected to help the reader find quality literature.

It is important to point that neither of these public library types is 'better' or 'worse' - both have their advantages and disadvantages. However, the American public library type (which supports the principle of neutrality) may potentially provide a more diverse repertoire for governance than the German public library type, which is mainly intended for educating people. Based on its openness, the American public library performs the function of educating (via quality literature), while its neutrality also opens the door for a dialogue that could be difficult to conduct in a somewhat unequal teacher-learner relationship. The difficulty of starting a dialogue (between the public library and its user) is also demonstrated by the aforementioned debate, which can essentially be treated as a conflict between the principles of two prominent public library types. Since public library users are used to the public library embodying the basic values of one or the other public library type, the values (accepted by the users) may also lead to a conflict if the other set of basic values is introduced.

\section{Altering the position of the library users}

As mentioned in the section on the analysis of government, governance works through the interests, aspirations, etc. of those who are governed - thus it can be suggested that a mutually positive or even dialogic relationship (as Lepik (2013) has pointed out in the case of the articulation of a stakeholder) can be fostered between the library and the user within the framework of 'good' governance. The relationship which existed between the public library librarian and its user before the aforementioned debate on the roles of public libraries could be seen as a dialogical one since it allowed the librarians to take the wishes of the library users into account. 
However, it was replaced by a predominantly pedagogical relationship where the reader was positioned as a 'learner' and was left without a voice in the decision-making process for choosing new books. However, the question is, since the library users had the possibility to participate in the dialogue for some time, can they now be demoted to the position of a reader, learner - one who needs to be educated?

Firstly, the reasons for visiting a public library can be very diverse - the wish to search for a particular kind of literature, to browse the latest magazines, to check on the new arrivals at the library, etc. Secondly, the relationship between the visitor and library may already have changed substantially. In addition to the role of learner (who can be 'disciplined') or the role of customer (who can be categorised as a member of one of the library's target groups), the visitor can also assume the role of a partner or stakeholder - who is distinguishes from other visitors by a dialogical relationship, and whose ideas and support can be incorporated into the library's activities (Lepik 2013). The library user may find that volunteering at a public library is interesting, and that he or she can help, for instance, when the collections need to be moved from one library building to another (Loonet 2011). The visitor can also become a book donor, helping public libraries to acquire their desiderata (or to replace lost library books (Tartu Linnaraamatukogu)). It is precisely in this light that the question of the intervention of the state in reading should be questioned, as it may have a much broader impact that goes far beyond the act of reading.

The position of the librarians is altered accordingly: are they just 'serviceproviders' who hand nationally accepted 'good' books across the service desk to the users, or do they consider the users' real reading interests and the interest of the library itself? Eventually, the affordances of the public library institution are at stake: are libraries seen as more than just repositories that preserve, organise and provide access to information, or are the diverse functions of the public library acknowledged - a diversity that the librarians are very well aware of?

\section{Conclusion}

Questions related to changes in the roles and positions of public libraries, librarians and readers help to analyse governmentality in the context of public libraries, and more broadly, to analyse the nationwide 'reading policy' as a mode of governance. However, when posing such questions, it is necessary that the analysis of different positions is not included in the agenda only in "crisis situations' when some foundations are questioned or just left without any attention. As mentioned above, the government (in Foucauldian terms) is undertaking rational decision-making, which cannot efficiently take place in an atmosphere that is emotionally loaded. This is one of the reasons that attention needs to be 
paid a debate that was particularly relevant two years ago: the previous decision is starting to have a visible impact on the activities of public libraries; the first experiences have been collected and first lessons learned. Therefore, this paper can act as a reminder, stressing the importance of regularly analysing national 'reading policy'.

To conclude - it is crucial to take the various traditions and foundations of public libraries into consideration in order to establish a coherent cultural or reading policy that will work on various societal levels (micro, meso and macro levels). The forcible implementation of a reading policy accompanied by the consideration of only few objectives (the cost-benefit, nationwide aims, etc.) may cause resistance, potentially resulting in consequences that contradict the initial aims. As such, the idea of promoting the best works by Estonian authors to Estonian readers may be a good cause, but the implementation of this idea can be viewed as questionable, and serve as a lesson for similar undertakings in the future.

\section{References}

Carpentier, N. (2013). Quality Discourses: Community Media Articulations of Democratic and Negotiated Quality. In I. Tomanic Trivundža, N. Carpentier; H. Nieminen, P. Pruulmann-Vengerfeldt, R. Kilborn, E. Sundin, T. Olsson (Eds.), Past, future and change: Contemporary analysis of evolving media scapes. Ljubljana: University of Ljubljana Press.

Dean, M. (1999). Governmentality: Power and Rule in Modern Society. London, Thousand Oaks, New Delhi: Sage.

Eesti kirjanduse toetusprogramm. Retrieved October 30, 2013 from http://www.kul.ee/ index.php?path=1919

Foucault, M. (1983). Afterword. The Subject and Power. In H.L. Dreyfus \& P. Rabinow (Eds), Michel Foucault. Beyond Structuralism and Hermeneutics. Chicago: The University of Chicago Press.

Foucault, M. ([1978] 2007). Security, Territory, Population: Lectures at the College de France, 1977-1978. New York: Picador; Palgrave.

Holm, K. (2011). Olukorrast rahvaraamatukogudes. Sirp, 24/11. Retrieved October 30, 2013 from http://www.sirp.ee/index.php?option=com_content\&view $=$ article\&id $=1$ 3456 : olukorrast-rahvaraamatukogudes \& catid $=9$ : sotsiaalia \&Itemid $=13 \&$ issue $=3370$

Holm, K. (2013). Raamatukogude toetamist vähendades ei adu valitsus nende kaalukust. ERR Uudised, 30/10. Retrieved October 30, 2013 from http://uudised.err. ee/?06290265

Koren, M. (2009). THE NETHERLANDS Nordic Plus. Scandinavian Library Quarterly, 42(4), online. Retrieved October 30, 2013 from http://slq.nu/?article= the-netherlands-nordic-plus-reading-promotion-in-the-netherlands

Kultuuripoliitika põhialused aastani 2020 (2013). Retrieved November 15, 2013 from http://www.kultuuripoliitika.ee/files/Kultuuripoliitika_pohialused_2020_EELNOU. pdf 
Lang, R. (2011). Raamatukogupäevade “Kohtume raamatukogus!” 2011 avamine 20.10.2011 [kultuuriministri kõne]. Retrieved October 30, 2013 from http:/www. keskraamatukogu.ee/ jagatud/videod/raamatukogupaevad2011/rein_lang/

Lauristin, M. (2013). New Media and Changes in the Forms of Cultural Transmission: The Estonian Experience. In P. Runnel, P. Pruulmann-Vengerfeldt, P. Viires, M. Laak (Eds), The Digital Turn: User's Practices and Cultural Transformations. Frankfurt am Main: Peter Lang.

Lauristin, M. \& Lõhmus, M. (2010). Cultural participation. In M. Lauristin (Ed.), Estonian Human Development Report 2009. Tallinn: Eesti Koostöö Kogu.

Lepik, K. (2013). Governmentality and cultural participation in Estonian public knowledge institutions. [PhD Thesis] Tartu: University of Tartu Press. Retrieved October 30, 2013 from http://dspace.utlib.ee/dspace/handle/10062/32240

Lepik, K. \& Carpentier, N. (2013). Articulating the visitor in public knowledge institutions. Critical Discourse Studies, 10(2), 136-153.

Linkgreim, I.-G. (2012). Ministeerium avalikustas raamatukogude kohustusliku ostunimekirja. ERR Uudised, 03/01. Retrieved October 30, 2013 from http://uudised.err. ee/?06242506

Loonet, T. (2011). 700 raamatusõpra aitasid Läänemaa raamatukogul kolida. Postimees, 14 March. Retrieved July 19, 2013 from

http://www.postimees.ee/402770/700-raamatusopra-aitasid-laanemaa-raamatukogul-kolida/

Lõhmus, M., Lauristin, M. \& Siirman, E. (2009). The Patterns of Cultural Attitudes and Preferences in Estonia. Journal of Baltic Studies, 40(1), 75-94.

McDaniel, J. E., Sims, C. H. \& Miskel, C. G. (2001). The National Reading Policy Arena: Policy Actors and Perceived Influence. Educational Policy, 15(1), 92-114.

Raamatukoguhoidja ja infotöötaja eetikakoodeks. Retrieved October 30, 2013 from http://www.eru.lib.ee/www/index.php/raamatukogundus/dokumendid/ eetikakoodeks

Rahvaraamatukogu töökorralduse juhend. Vastu võetud 12.07.2004 nr 9, RTL 2004, 97, 1529 jõustumine 23.07.2004. Retrieved October 30, 2013 from https:/www. riigiteataja.ee/akt/12828432

Sepp, I. (2002). Rahvaraamatukogud. In S. Lauk, E. Sandberg \& T. Vilberg (Eds.), Raamatukogud ja raamatukogundus taasiseseisvunud Eestis: Libraries and Librarianship In Newly Independent Estonia. 1991-2001. Tallinn: National Library of Estonia.

Tartu Linnaraamatukogu. Asendusraamatud. Retrieved July 19, 2013 from http://www. luts.ee/index.php?option $=$ com_content $\&$ view $=$ article $\&$ catid $=39 \% 3$ Alugejale $\& i d=7$ 43\%3Aasendusraamatud\&Itemid $=179$

UNESCO Public Library Manifesto. Retrieved October 30, 2013 from http://www.unesco.org/webworld/libraries/manifestos/libraman.html

Valm, T. (2002). Raamatukogud silmitsi muutustega. In S. Lauk, E. Sandberg \& T. Vilberg (Eds.), Raamatukogud ja raamatukogundus taasiseseisvunud Eestis: Libraries and Librarianship In Newly Independent Estonia. 1991-2001. Tallinn: National Library of Estonia, 9-20.

Volodin, B. (2005). Maailma raamatukogude ajalugu. Tallinn: Eesti Rahvusraamatukogu. 


\title{
Reading, democracy and discipline: Premises for reading activities in Swedish primary schools from 1967 to 1969
}

\author{
Mats Dolatkhah, Anna Lundh
}

\begin{abstract}
Introduction
In Sweden, as well as in many other countries, children's literacy is a much debated topic. In the public discourse, politicians, researchers, and other groups are discussing the reading abilities, reading habits, and changing media preferences of children and youth. These discussions encompass several different lines of thought, but perceived problems with computers, digital media, and document technologies are often at the heart of the debate. For example, the computerisation of children's home environments has been interpreted as one of the major causes for the decline in traditional reading interests and reading skills among children and youth (Rosén 2012). It has also been argued that the heavy use of digital media actually restructures the human brain and makes it more suited to superficial skimming and scanning than the in-depth concentrated reading associated with traditional printed books (Carr 2010). Some studies have found that educators and librarians associate printed books with good childhoods, and digital media technologies are thought to endanger the childhoods of contemporary children (Lundh, Davidsson \& Limberg 2011).

In these discussions, many different values are attributed to book reading. Some relate to cognition, such as creative imagination, concentration, as well as linear, abstract, and complex thinking. Other values are social, such as the idea of book reading being a part of a good childhood. In the Swedish debate, researchers and politicians also connect the reading of literature to the democratic capital of the society. It is seen as a practice by which the citizens access the information they need and by which they can develop and mature as potential political actors (Government Bill 2013/14:3; Persson 2007).

In summary, it can be said that the contemporary discussions of reading often centre on an experience of transition from one culture or practice of reading to another, and on the role played by new media technologies in this
\end{abstract}


process. We argue that in order to understand this transition - and the experience of it - it is important to explore not only the most recent developments and the use of new media technologies today. It is also important to critically scrutinise historical evidence of the culture of reading that we are now said to be leaving behind, and thus avoid taking it for granted.

This article is one of the first steps in a larger research project, Reading, traditions and negotiations: Reading activities in Swedish classrooms 1967-1969, which is an examination of how reading as an activity was shaped in Swedish primary schools in the late 1960s. The primary data for this project consist of a large number of video and sound recordings from Swedish primary school classrooms between 1967 and 1969. By analysing this material, we hope to contribute to the understanding of changing reading habits by investigating an important part of Swedish reading culture as it developed in the decades after World War II, namely the reading practices taught in the schools. The public school system was one of the most important cornerstones in the building of a reading culture in post-war Sweden, and it was also a product of particular historical and societal circumstances and ideologies.

Since an important aspect of reading practices is the degree to which they are embedded in historical circumstances and institutions, a contextual understanding is required for the research project generally. Christine Pawley, who studies the history of reading, has drawn attention to organisations, both commercial and public, as foci for the research on reading practices (Pawley 2009). Organisations, she argues, represent a theoretical meso-level of analysis, where the interplay between macro-level structures and micro-level actions occurs. Pawley pays particular attention to structural categories such as gender, race and class. We assume that organisations can also mediate and manifest structural phenomena such as ideologies and discourses, and that they are places where individuals can negotiate, contest, adapt to, and contribute to such structures.

During the decades after the World War II, the Swedish educational system was thoroughly reformed. In 1962, a new curriculum instituted comprehensive and compulsory public schooling, which was intended to tackle certain social and political issues. In addition, the curriculum provided the school system with a normative conceptualisation of reading. Analytically, the institution of the new comprehensive and compulsory school system - and its curriculum can be seen an important link between reading as an activity and broader societal circumstances. The intention of this paper is to lay a foundation for our further studies, by analysing the historical and institutional context in which school reading took place, with a particular focus on the curriculum and its conceptualisations of reading that was current at that time. 


\section{The curriculum as a premise for reading activities}

The curriculum that is our focus is called Läroplan för grundskolan 1962 [Curriculum for Comprehensive Schools 1962]. Some comparisons will also be made with the predecessor for the elementary schools (in Swedish, folkskolan), Undervisningsplan för rikets folkskolor den 22 januari 1955 [Teaching Programme for the Country's Elementary Schools 22 January 1955], and its successor, Läroplan för grundskolan 1969 [Curriculum for Comprehensive Schools 1969] (1969).

The 1962 curriculum consists of four parts, not counting the appendices. The schooling goals and guidelines in general and abstract terms are presented in the first part, while the second presents more tenable instructions. These consider the relationships between the school, home, and society at large, but more specifically, the internal organisation and work of the schools. For example, the methods for teaching and grading, as well as, how to teach classes for children with special needs. The second part also provides instructions for resources, such as the school's health service, study and vocational guidance services, and school libraries. In the third part we find the time schedules for each year and subject. The subjects as such are described in the fourth part, which is also the largest.

In this article, we will focus on the subject of Swedish, as described in the fourth part of the curriculum. The section where Swedish is described as a subject is the largest subject section and consists of 40 pages. Of course, it could be argued that reading as an activity is an integrated aspect of most subjects; however, it is an explicit object of teaching in the subject of Swedish. The main interest of this article is how this object of teaching is conceptualised. Before moving on to these conceptualisations, however, we will consider A) the institution of comprehensive and compulsory schooling and B) the subject of Swedish as a whole, within which reading was to be taught.

\section{Comprehensive and compulsory schooling as a political project}

In essence, the post-war reforms of the school system constituted a transition from a hierarchical and differentiated school system to a nine-year compulsory and comprehensive school system. This has been described as the most significant reform in Sweden since schooling was institutionalised in 1842 (Thavenius 1999: 15). Primary education was now the same for all children, except for some optional subjects and the $9^{\text {th }}$ year, when opportunities for some specialisation in more or less practical or theoretical classes were provided.

Traditionally, the implementation of comprehensive and compulsory schooling is seen as a result of a political spirit of democratic progressivism. As an institution, this new type of school was intended to strengthen the democratic 
values in society. The experience of World War II and the totalitarian regimes in Europe provided the background for this and the goal of the new public school system was to educate citizens who were capable of actively participating in a democratic society. Also, the social democratic educational policy was aiming at giving all children equal access to education regardless of socio-economic background (Richardson 2010: 111-116).

The curriculum repeatedly places the education of the democratic citizen alongside the goal of individual personal growth and the goal of social responsibility. The importance of individualization contrasts with school systems in other countries and periods where violations of individual personality and strongly suggestive teaching led to the creation of "uniform collectives" (Läroplan för grundskolan 1962: 32). However, individualisation was to be complemented by social responsibilities - to family, society, and other societies. (Läroplan för grundskolan 1962: 18 and passim). This balance is repeatedly stressed in the curriculum and especially in its general goals and guidelines.

In recent research, the interpretation of the comprehensive school based on the processes of progression and democratisation has been challenged, or at least "destabilized". Using Michel Foucault's genealogical perspective to question the view of historical processes as linear, teleological, and progressing on historical processes, Jonas Qvarsebo, a historian of education, has suggested that the disciplinary regime in the schools actually expanded and intensified during the period leading up to 1962, although in a different form than before (2013).

The progressivists claimed that the school system needed to steer clear of authoritarian disciplinary methods, and let democratic, individual personalities develop. However, others were worried about the development of a youth culture, and the new behaviours and attitudes were seen as threatening to the social order. Many teachers - faced with the practical task of maintaining a degree of discipline in the classroom - as well as conservative politicians, were of this mind when it came to the schools (Qvarsebo 2013: 224).

New disciplinary methods were developed. According to Qvarsebo, the manual for the children's teaching and growth, which was intended for the higher forms (issued by the National Board of Education in 1959), considered the ideal disciplinary method to be peer-to-peer measures, with the teacher monitoring the situation from a distance (Qvarsebo 2013: 230). Another way of reinforcing the disciplinary power of the school was to extend the discipline into the homes and families of the schoolchildren. Through new methods, including information meetings, counselling and contact books, the norms of the school were to be transferred into the homes, which were seen as potential hearths of "negative patterns of behaviour" (Qvarsebo 2013: 231). In minute detail, different campaigns for character formation sought to regulate the behaviour and conduct of the schoolchildren.

All translations from Swedish originals are made by the authors. 
Qvarsebo's argument is that the stern authoritarian methods and targets of discipline were transformed, “...from the surface of the body of the disobedient pupil to more complex and efficient systems of internal discipline of the soul and behaviour." (Qvarsebo 2013: 234). However, the disciplinary regime as such was actually expanded and intensified by this transformation. Thus, the activity of reading took place in an institution characterised by paradoxical dynamics which allowed democratic progressivism to lead to an expanded disciplinary system.

\section{The subject of Swedish}

A closer examination of the curriculum reveals that a fundamental part of the institution in which reading was taught, i.e. the main components of the subject of Swedish, include not only "reading", but also "speech", "writing", "linguistic observations and practice" and "Danish and Norwegian". Swedish had a central position in the curriculum and it constituted about $30 \%$ of the scheduled teaching hours (Ewalds 2007: 111). The subject of Swedish, as manifested in the curriculum, has been interpreted as an expression of modernisation. Earlier, Swedish as a subject - "the mother tongue"- was based on the foundations of language and literature, tied to a tradition of "bildung", and was permeated by religious and nationalistic values (Kåreland 2009: 102ff; Malmgren 1996: 94). In the 1962 curriculum, the subject was formulated in a way that would let the pupils function well in a modern, industrialised, media society (Malmgren 1996).

The goals for teaching of Swedish, as stated in the curriculum, are to let the pupils develop their abilities to understand and evaluate what they hear, see, and read, and to clearly and correctly express themselves. Exercises in listening, viewing, speaking, reading, and writing were supposed to develop these abilities. Therefore, the teaching should fulfil the different demands of everyday life, as well as contribute to the pupils' general knowledge, personal development, independent creativity, and ability to cooperate. The curriculum further states that teaching the subject of Swedish should lay the foundation for study skills, invoke a desire for reading, as well as an interest in good literature and the beauty of language. Some modern authors and the language and literature of the Nordic states should also be taught to the pupils. (Läroplan för grundskolan 1962: 125)

When presenting reading as a part of the subject of Swedish, it should be pointed out that the curriculum explicitly states that the division into different components has been done solely to provide an overview. When it comes to teaching, the curriculum states that the unity of the subject should be maintained by joining the different components into thematic studies, for example. 


\section{Reading conceptualised}

In the 1962 curriculum, the teaching of reading is divided into five main sections. For the middle school, these are:

1. Reading practice and study skills

2. Information reading

3. Experience reading

4. Independent reading

5. Prepared oral reading

These reading styles are carefully described in the curriculum, with regard to the different forms. Silent as well as oral reading is included, as are basic bibliographical skills, and the use of phonebooks and timetables. Instructions for teaching basic reading skills are also proposed for the lower forms, as well as suggestions on how reading can be incorporated in other parts of the subject of Swedish, as well as into other subjects. It is emphasised that reading should always take place in natural circumstances. Texts, reading styles, and reading materials chosen for exercises should also match the maturity of the students. For example, the critical reading of texts with commercial or political agendas should be practiced in the higher forms. The point is that it should be able to understand the texts without very detailed instructions or comments. "The schools should guide the pupils from fairytales through youth books to proper literature." (Läroplan för grundskolan 1962: 145).

A wide range of reading materials is mentioned; for example, textbooks, encyclopaedias, brochures, magazines, and journals. Among the genres and topics suggested are stories about animals, stories about children home and abroad, adventure stories, and stories about children's everyday experiences. Young teenagers are supposed read adult literature, but care should be taken to satisfy their interest in fast-paced, exciting stories and their need for ideals, dreams of faraway places, and expectations for growing up (Läroplan för grundskolan 1962: 145). Extensive book collections and classroom libraries are seen as necessities (ibidem: 151) and the potential of school libraries is discussed. The curriculum repeatedly stresses that the text chosen for reading must fit the maturity and interest of the pupils.

Pictures are also seen as relevant sources of information, along with fantasy experiences, but how they are to be interpreted requires attention (ibidem: 148). "Audiovisual" media, such as film, radio, and TV, are treated as a separate component of Swedish, called Listening, viewing and speaking. It might be of interest to note that this is not the case in the 1969 curriculum that followed, in which the interpretation of film and TV are treated as parts of reading.

The 1962 curriculum, defines information reading as non-fiction such as encyclopaedias, textbooks, magazines and journals, as well as maps, tables and diagrams. Textbooks on other subjects are also considered suitable (Läroplan 
för grundskolan 1962: 145ff). Localising particular facts, speed reading, and scanning are aspects of this type of reading, which also includes interpretive intellectual operations, such as critical scrutiny, summarizing, and drawing conclusions from what is read. Techniques such as taking notes in the margins and underlining particularly significant parts are to be practiced (ibidem: 148). When assigning homework - a means of independent training in study skills attention should be paid to the "varying home environments" of the students, and the teachers should discuss the subjects of the assignments to be completed at home with the parents (ibidem: 149).

Terminologically, "experience reading" is a translation of the Swedish term upplevelseläsning, which generally, and also in this particular context, has rather strong connotations of reading for pleasure. However, we wish to avoid that translation, as the curriculum assigns other purposes to this kind of reading beside "pleasure", such as "aesthetic growth", development of good taste, etc. Perhaps it should also be noted that "experience reading" as conceptualised in the curriculum is not primarily aimed at making the pupils into experienced readers.

Experience reading is to be applied to fiction and literature, and can also be used to provide depth to and enrich the studies of other subjects. Experience reading is meant to contribute to personal growth, "aesthetic growth", and the development of good taste. Besides, it is noted that reading for pleasure will lead to an expanded vocabulary and other language skills. The curriculum states that students should engage in extensive reading for pleasure. Independent reading, with individual guidance provided on book choice, is supposed to invoke a desire to and a joy for reading, but it is also a way of satisfying the pupils' "legitimate" need for fantasy experiences within the school environment (Läroplan för grundskolan 1962: 151).

The curriculum states that discussions of fictional texts can be used to explore ethical and social problems, thereby contributing to the sense of responsibility and solidarity with the family and community and "....also with humans of other races, cultures and environments" (ibidem: 146). But some literary texts should also be allowed to "...speak for themselves, without any comments whatsoever" (ibidem: 148). Recordings can be used to make the teacher into a listener, instead of a reader, with the others. This is also the case with lyrics and poetry. Regarding these genres, the curriculum states that "The less instruction from the teacher the better" (ibidem: 150), and adds that the mood and the message as a whole are more important than word-for-word comprehension. It is also considered suitable to read poetry on special occasions, such as the appearance of the first spring flowers (in Sweden, the changes of seasons are considered to be special occasions).

From the start of their education, the pupils are meant to practice and use both silent and oral reading. However, the emphasis is supposed to move from oral to silent through the course of their studies, which implies a progression in these ways of reading. Prepared oral reading is focused on fiction, and has the potential 
of invoking strong, shared experiences. It is also considered suitable to combine prepared oral reading with choral singing, dramatisation, and music.

Both information reading and experience reading are intended to influence the pupils' reading habits outside of school. Information reading should contribute to the pupils' own learning about topics of interest, and experience reading should "if possible" focus on growth (Läroplan för grundskolan 1962: 145). Social reading circles and reading groups should be encouraged by the teacher. These activities can contribute to the recitations and dramatisations performed by the students on occasions such as parental and school meetings. When discussing school libraries, the curriculum states that pupils should develop good reading habits. The pupils should, of their own accord, be able to distinguish and reject books that are "accessible", but of "dubious value" (ibidem: 100f).

In summary, the conceptualisation of reading is quite multifaceted - perhaps even fragmented - in the 1962 curriculum. This pertains both to the reading styles as such, and to the kinds of texts considered suitable for reading. However, the underlying structure is divided between fiction and experience reading on the one hand, and non-fiction and information reading, on the other (see Malmgren 1996: 94). The other reading styles that are mentioned can often be understood to be aspects or versions of these two fundamental forms of reading.

\section{Reading as a democratic and disciplinary activity}

To some extent, the concepts of democracy and discipline seem to be useful concepts for interpreting the conceptualisation of reading in the 1962 curriculum. It could reasonably be argued that elements of discipline are present in most educational situations, and that education itself is a form of discipline. It is also important to note that this does not necessarily contradict the concept of democracy. Discipline may well be inherent to a democratic project, as its actors need to submit to certain norms. However, we are interested in how specific democratic and disciplining aspirations are manifested in the 1962 curriculum. Discipline and democracy may take different shapes in different institutions and situations. We suggest that the dynamics between the specific disciplinary and democratic projects comprised in the new institution of comprehensive school were parts of a historical situation in which a modern culture of reading was established.

Qvarsebo (2013) points out that one fundamental aspect of this kind of discipline is the idea that the norms of the school were supposed to be transferred to the homes and families of the pupils. This idea is also apparent - though not to a great degree - in the instructions on reading. One part of this idea was making sure that the home is a good environment for doing homework, with what was called a proper "study hygiene". The explicit intention to impact 
the pupils' spare-time reading by developing their literary taste can be seen as another example of how reading was incorporated in a disciplinary project aimed at extending school norms into other parts of society.

However, the 1955 curriculum is actually a clearer example, where the teaching of reading was explicitly intended to counter children's reading of "simpler comic books and other dubious literature" (Undervisningsplan för rikets folkskolor den 22 januari 1955: 72). ${ }^{2}$ Such reading habits were supposed to motivate consultations with the parents, and this idea corresponds to the general disciplinary strategy of extending the norms of the school into the homes and families. In comparison to its predecessor, the 1962 curriculum is thus not as explicit in this regard.

Malmgren regards the division between information reading and experience reading as an expression of modernisation (Malmgren 1996: 94). But we would argue that it actually seems to be an iteration of a classical distinction in the history of reading, which, in some version, dates back at least to Cicero and his remarks on those who read history for pleasure rather than for usefulness (Cavallo 2003: 67). The other forms of reading indicated in the curriculum such as "independent reading", "prepared oral reading" and "study skills" - can often be seen as aspects of these two fundamental elements. Unlike Cicero's readers of history, the pupils were to be taught to apply different reading styles to different categories of documents, to fact and to fiction.

The idea of democratisation through equal access to education is apparent in information reading. Information reading was closely linked to the practice of study skills, which provided pupils from disadvantaged backgrounds with better prerequisites to enter secondary and tertiary education (Malmgren 1996: 15). Some of the instructions related to experience reading may be interpreted as expressions of more general anti-authoritarianism, as democratic ideals aimed at strengthening the individual personality, and avoiding the creation of uniform collectives. Partly, experience reading was seen as a means of entering ethical, social and political discussions. But the curriculum also explicitly instructs the teacher to refrain from imposing their own interpretations on the pupils' experience reading, or at least, in case of some of the texts read in this style. The individual pupil's own interpretations were to be given precedence at least in some occasions, thereby allowing space for the democratically important independent spirit. These kinds of ideas, as well as the legitimacy of individual fantasy experiences in school, were severely criticised during the 70 s. A radical group of pedagogues particularly criticised the practice of independent

The year before the curriculum of 1955 was enacted, physician Nils Bejerot had launched a vigorous frontal assault on comic books in his influential book Barn, Serier, Samhälle [Children, Comics, Society] (1954/1981). This book was a Swedish parallel to Wertham's Seduction of the innocent, and suggested that it was not inadequate to draw parallels between certain kinds of comics and narcotic drugs (Bejerot's professional specialisation). 
reading as "pornographic" as it was centred on the individual's private experiences and wasn't used to explore moral and societal issues for educational purposes (Ehrlin \& Malmgren 1976, passim).

However, we wish to emphasise that the curriculum is an expression of an ideology and of different norms of what reading should be like. In contrast to the democratic idealism expressed in the curriculum, commentators with insights into school practices at the time present a somewhat different picture. In practical teaching, the subject of Swedish ran the risk of fragmenting into many different small elements focused on formal skills rather than on content and literature. In particular, this was often the case in the more practically oriented classes in the 9th form (Dahl 1999).

During the 1960s, another important characteristic of the practical teaching of Swedish (as well as school teaching in general) was the large presence of commercial, comprehensive teaching materials. The influence of these materials was great, not least because there was a shortage of educated teachers, and it was easy for substitutes and new teachers to use these teaching materials. Since the pupils worked with the textbooks and exercise books at their own pace, opportunities were also provided for developing the ideologically important aspect of individualisation, which we touched upon earlier (Dahl 1999: 46ff, Malmgren 1996: 15).

In regard to reading in particular, Annette Ewalds, a researcher and former teacher, remembers that when practicing experience reading in the 1970s, the class silently read a text chosen by the teacher and then answered questions prepared by the author. The answers were then reviewed. Sometimes these reviews led to broader discussions, but usually, the aim was just to establish the correct answers. "Independent reading" was used to fill the gaps in scheduled teaching, for example, at the end of lessons. And even if the pupils had to present heir reading when they finished a book, the pedagogical aspirations were usually limited (Ewalds 2007: 113ff).

\section{Reading and societal change}

Researching the near past is a productive way of gaining perspectives on the present. If we compare these findings to the present debate, we find that some of the qualities we decry today and associate with the advent of digital media technologies, such as quick skimming and scanning through textual fragments, were actually part of the reading skills taught in the public schools in the 1960s, at which time it was applied to print materials. Study skills and information reading contained these elements, which were considered to be important in order to provide equal access to education. Thus this style of reading was promoted by particular political interests in a particular societal situation. 
Characterising today's changes in reading habits as a shift from the indepth, linear reading of printed books to a quick, fragmented form of scanning - and blaming it all on new technologies - is a simplified view. "Fragmented" and quick skimming and scanning are certainly not new ways of reading that appeared along with digital media technologies, but are social practices, which we may or may not choose to teach children with or without particular political goals in mind. As we can see in the document analysed here, these ways of reading were actually seen as desirable and as objects of teaching and learning in the 1960s.

Of course, this is not to say that different reading technologies are not central prerequisites for reading; however, the impact of technologies also depends on social organisations, values and expectations. While new media technologies may inherently promote certain styles of reading, so do the social and political initiatives and institutions in our past and present.

For example, some versions of the form of discipline pointed out by Qvarsebo are still present - and have been accentuated - in contemporary schooling. However, Qvarsebo primarily considers the discipline of behaviour and character formation to be a paradox similar to the one between individualization and discipline that is encountered in the pedagogical work in contemporary schooling. When analysing more recent classroom interactions during the 1990s and 2000s, Swedish researchers (Alexandersson \& Limberg 2012; Bergqvist \& Säljö 2004; Carlgren 2005; Lundh 2011; Österlind 1998) have described how the student-centred teaching methods, which became widespread during these decades, engendered a paradoxical freedom for the students, who had to learn how to take responsibility for their own school activities, while simultaneously conforming to the explicit and implicit expectations for their behaviour and learning outcomes. All these studies (Alexandersson \& Limberg 2012; Bergqvist \& Säljö 2004; Carlgren 2005; Österlind 1998) are influenced to some extent by Foucault (1979) and describe how these teaching methods lead to an internal disciplining of students, as opposed to an external physical disciplining - something that Qvarsebo (2013) also identified in the reforms leading up to the 1962 curriculum.

These issues of discipline are important to reading. The reports of the declining interest in reading and the loss of skills related to reading books and literature among children and young people today are raising a lot of concerns among politicians, researchers and teachers. Different initiatives for promoting reading have been implemented at various levels of society to counter these tendencies. However, research often assumes that the promotion of reading among children and youth works best if they feel that reading is voluntary and subject to individual freedom, and the feeling of compulsion is avoided (Krashen 2011).

Here the paradoxical dynamic between anti-authoritarian ideals and discipline reappears - what should be done with those students who would use their 
freedom to choose activities others than reading books. The 1962 curriculum expected the pupils to develop an internal sense of literary quality and voluntarily refrain from reading low-quality materials. Similar expectations exist today, even if literary quality may be less pertinent today than the choice between different types of media. Another view of the current changes in reading habits is presented by the proponents of "new literacies", who are reluctant to prioritise literature or books. The case is made that the character of reading is always multifaceted and that important literacies are developed through children's often voluntary - use of different kinds of media-related, linguistic and symbolic expressions (Fast 2008).

During the last decades, research into the history of reading has also contributed to an increased understanding of the complexity of reading. Sequential histories of reading, divided into neat phases each characterised by a particular practice of reading, run the risk of oversimplification. As David D. Hall, a historian studying literacy, has pointed out (1996): a reader may, in any historical situation, have access to several different models and traditions of literacy. This is quite evident in the 1962 curriculum, which could actually be seen as bordering on fragmentation, if it were not for the explicit instructions related to the requirement to always maintain the unity of the subject of Swedish (which were not always followed in practice).

The curriculum expressed a normative and institutionalised conceptualisation of reading in effect during the period of interest. However, as Pawley (2009) points out, reading is often shaped by the interplay of structures and actors within the framework of institutions. Therefore, in upcoming papers we will explore reading practices as they were implemented in the field of tensions that developed between the institutional ideologies of the new comprehensive school system and the children and teachers as individuals in particular situations.

\section{References}

Alexandersson, M. \& Limberg, L. (2012). Changing conditions for information use and learning in Swedish schools: A synthesis of research, Human IT, 11(2), 131-154.

Bejerot, N. (1954/1981). Barn, serier, samhälle. [Children, comics, society]. Stockholm: FIB/Kulturfront.

Bergqvist, K. \& Säljö, R. (2004). Learning to plan: A study of reflexivity and discipline in modern pedagogy. In J. Van der Linden, \& P. Renshaw (Eds.), Dialogic learning: Shifting perspectives to learning, instruction and teaching. Dordrecht: Kluwer Academic Publishers.

Carlgren, I. (2005). Konsten att sätta sig själv i arbete: Om betydelsen av eget arbete för att skapa människor som styr sig själva. [The art of putting yourself to work: On independent work as a way of creating self-regulatory people]. In E. Österlind (Ed.), Eget arbete: En kameleont i klassrummet: Perspektiv på ett arbetssätt 
från förskola till gymnasium [Independent work: A chameleon in the classroom: Perspectives on working methods from pre-school to upper secondary school]. Lund: Studentlitteratur.

Carr, N.G. (2010). The shallows: What the Internet is doing to our brains. New York: W.W. Norton.

Dahl, K. (1999). Från färdighetsträning till språkutveckling. [From proficiency training to language development]. In J. Thavenius (Ed.), Svenskämnets historia [The history of the subject of Swedish]. Lund: Studentlitteratur.

Ehrlin, A. \& Malmgren, L.-G. (1976). Den heliga upplevelsen. [The holy experience]. In B. Brodow et al. (Eds), Svenskämnets kris [The crisis of the subject of Swedish]. Lund: Liber Läromedel.

Ewald, A. (2007). Läskulturer: Lärare, elever och litteraturläsning i grundskolans mellanår. [Reading cultures: Teachers, pupils and literary reading in the middle years of comprehensive school] Diss. Lund : Lunds universitet, 2007. URL: http:// dspace.mah.se/bitstream/handle/2043/4095/Ewald\%2520Avhandling\%2520MUEP. pdf? sequence $=1$

Fast, C. (2008). Literacy: I familj, förskola och skola. [Literacy: In families, preschool and school]. Lund: Studentlitteratur.

Foucault, M. (1979). Discipline and punish: The birth of the prison. (Peregrine Books). Harmondsworth: Penguin.

Government Bill 2013/14:3. Läsa för livet. [Read for life]. Stockholm: Government offices.

Hall, D.D. (1996). Cultures of print: Essays in the history of the book. Amherst: University of Massachusetts Press.

Krashen, S. (2011). Free voluntary reading. Westport, CT: Libraries unlimited.

Kåreland, L. (2009). Barnboken i samhället. [The children's book in society] 1. ed. Lund: Studentlitteratur.

Lundh, A., Davidsson, B. \& Limberg, L. (2011). Talking about the good childhood: An analysis of educators' approaches to school children's use of ICT. HumanIT, 11(2), $21-45$.

Läroplan för grundskolan. [Curriculum for the compulsory school] (1962). Stockholm: Kungl. Skolöverstyrelsen.

Läroplan för grundskolan. 2, Supplement: Kompletterande anvisningar och kommentarer. Svenska. [Curriculum for the comprehensive school. 2, Supplement: Complementary instructions and comments. Swedish] (1969). Stockholm: Skolöverstyrelsen; Utbildningsförlaget Liber.

Malmgren, L.-G. (1996). Svenskundervisning i grundskolan. [Teaching Swedish in compulsory school] 2.ed, [updated]. Lund: Studentlitteratur

Pawley, C. (2009). Beyond market models and resistance: Organisations as a middle layer in the history of reading. Library Quarterly, 79(1), 73-93.

Persson, M. (2007). Varför läsa litteratur? Om litteraturundervisningen efter den kulturella vändningen. [Why read literature? On the teaching of literature after the cultural turn.] Lund: Studentlitteratur.

Qvarsebo, J. (2013). Swedish progressive school politics and the disciplinary regime of the school, 1946-1962. A genealogical perspective. Paedagogica Historica, 49(2), $217-235$. 
Richardson, G. (2010). Svensk utbildningshistoria: Skola och samhälle förr och nu. [Swedish history of education: School and society past and present] 8. rev. ed. Lund: Studentlitteratur

Rosén, M. (2012). Förändringar i läsvanor och läsförmåga bland 9- till 10-åringar: Resultat från internationella studier. [Changing reading habits and reading skills among 9- to 10-year olds: Results from international studies]. In U. Carlsson \& J. Johannisson (Eds.), Läsarnas marknad, marknadens läsare [The readers' market, the market's readers]. Gothenburg: Nordicom.

Thavenius, J. (1999). Traditioner och förändringar. [Traditions and changes]. In J. Thavenius (Ed.), Svenskämnets historia. [The history of the subject of Swedish]. Lund: Studentlitteratur.

Undervisningsplan för rikets folkskolor den 22 januari 1955. (1955). [Curriculum for the elementary schools of the country the 22 january 1955] Stockholm: Kungl. Skolöverstyrelsen; Norstedt.

Österlind, E. (1998). Disciplinering via frihet: Elevers planering av sitt eget arbete. [Disciplining via freedom: Independent work and student planning]. Diss. Uppsala: Univ. Uppsala. 


\title{
Library lists and directed reading. Some episodes in the history of Estonian libraries
}

\author{
Asko Tamme
}

\section{Introduction}

The aim of this article is a perfunctory analysis of the role of recommended purchase and reading lists in Estonian librarianship, starting with the one published in the weekly newspaper "Olevik" in 1882 and finishing with the introduction of systematically prepared lists at the end of the 1920s.

Lists of reading material along with various statements on the quality of literature and reading in terms of book selection have always been part and parcel of modern librarianship. Modern librarianship is an outgrowth of the public library movement, which started with the Public Libraries Act of the British Parliament in 1850 and spread more or less in the same form over Europe and Northern America during the next 50 years. The organisational form of each public library depended on many variables. In England and Scotland, for instance, libraries were started in industrial cities and spread very slowly to rural areas or smaller boroughs (Black \& Hoare 2006). In the Baltic provinces of imperial Russia, public libraries for the local nationalities didn't reach towns until the beginning of the 20th century; up until then, they were an almost solely rural affair. In Great Britain, Germany and Russia, the proper public library movement did not acquire nationalist traits. But in the Estonian areas (Estland and the northern part of Livland) ${ }^{1}$, libraries became manifest components of building the nation. Quite obviously, libraries were not the crucial organisations of nation building - these were rather local self-government along with education and cultural activities, all of which were reflected in the multiple mirrors of the press, economic development and embryonic politics. In

1 One can safely presume that there were no real differences between the Estonian and Latvian areas. However, the latter is out of my scope here. 
this aspect, even our closest neighbour and model - Finland - offers a distinctly different precedent.

However, regardless of all the differences, libraries were always advocated and introduced as organisations of enlightenment and culture while conversely also always functioning as organisations of social control and placation. This is fairly evident and has been studied exhaustively in connection with British and American libraries ${ }^{2}$. My objective is to demonstrate how our history of libraries and reading can be analysed along lines that are not too different.

In general, in looking at how a library functions in society, two kinds of control become evident:

1. Direct control by the authorities, as expressed by various regulations (library acts, numerous lower level rules, lists). The clearest examples in our case are the arcane censorship network of imperial Russia, described by Veskimägi (1964) and Issakov (1979), and the Public Libraries Act of independent Estonia (adopted in 1924). Nowadays, we also have to abide by the contemporary Public Libraries Act and other laws pertaining to copyright, the local community, public finances, etc).

2. The second level of control, however, is essentially self-enforcing. In some aspects, it is practically indiscernible from normal, good manners (i.e. 'do not shout in the library'). In others, however, a transition from library routines and practices to general reading and library use occurs and the library starts to expect specific knowledge, social practices and behaviours from its readers.

This type of control, which I would call immanent control in an attempt to convey the idea that it comes from within the organisation and institutions, ${ }^{3}$ is very complicated and worthy of in-depth analysis. The numerous factors involved make it difficult to analyse. In the first place, authorities have a direct influence. Nevertheless, most of this kind of control is expressed more in the ideas, expectations, and opinions that people have of libraries. Large parts of it function without leaving any trace one could 'parse and construe'. But for our purposes, there are also substantial signs.

The importance of books and reading has been articulated in Estonian newspapers since the 1860s. Libraries were mentioned rarely, but when they were, it was obvious that they were regarded as an important part of the changes that society was undergoing. In these texts, the differentiations between 'good' and 'bad', 'worthy' and 'worthless' were always stressed (cf. Kreutzwald 1869, Jannsen 1870, Hurt 1939). By the 1880s, the more general texts had evolved

A thorough analysis of the social background of the library movement can be found in Black 1996.

3 It is important here to keep up with the traditional sociology of librarianship, which differentiates between organisations and institutions. A library is an organisation carrying out the social tasks put upon it by institutions of reading and education, cf. Shera 1949, Шира 1973, North 2004, Mäkinen 2008. 
into lengthy and detailed discussions. This was when Ado Grenzstein issued the first list of library material (Grenzstein 1882).

Henceforth lists became a major, though not the sole, means through which society related to libraries and by which libraries defined their tasks in and for society. There were still periods when there were almost no lists and when cultural and political discussions about the significance of public libraries took the principal position ${ }^{4}$. Lists are an exceedingly rich source for library research. But when setting out to analyse their content (i.e. which books were selected, how this reflected on actual purchases and, later on, reading), so many issues arise ${ }^{5}$ that it effectively becomes impossible to be comprehensive without extensive, quantitative research. This would be a possible route, but in the context of this report, I would rather limit myself to a description of their introductory and accompanying texts. To me, the accompanying discourse and the 'public truth' on libraries emerging from it better reflect the society's wish to direct public reading, what the compilers and publishers considered important, and the general position of the institution of reading vis-à-vis the public at large.

\section{The library censorship policy of imperial Russia, lists of approved library material}

Estonian librarianship got a proper, though not yet professional, start with the lengthy editorial „Raamatukogud" ("Libraries”) in the weekly newspaper "Olevik" by Ado Grenzstein in 1882. It starts with the appeal that each school should have its own library, which would also be accessible to others for general reading. He wrote: “... and it is our heart's desire that the Estonian people who read already, would become a real, reading people, meaning that they would become a people who increase their level of education alongside school through books. This is praiseworthy in all ways and truly possible." And later: „One who is able to read without trouble and is generally a person with an alert mind will not stop reading once he has started". In the first place, this was a clear-cut wording of expectations for fellow citizens (real, reading people). This list also rates the books according to some sort of value - out of approximately 370 volumes, 80 were considered to be 'a must', 75 to be purchased additionally for a medium-sized library, and 220 volumes were added if one wishes to have a big library.

$4 \quad$ This can be safely said about the period between 1905 and 1918 (see also below, the section 'Public Library Promoters in the 1910s').

5 As argued by Eskola (2004), the composition and/or the supposed influence of a list on library purchases does not necessarily immediately influence the actual acquisition policies, and even less the reading. She maintains that the proper significance of lists is disclosed by the comparison of lists to purchases and subsequently to actual print run data. 
Grenzstein's list came shortly before the acme of the library movement in the countryside in the mid-1880s. Active, nationalistic people took advantage of the relative freedom afforded by the liberal reforms of the 1860 s and the accompanying economic progress and founded scores of libraries before the times turned again 6 .

I would not say that the imperial power set out to deprive Estonians of their libraries. But in 1884, a provisional order for founding libraries was introduced (rendering it practically impossible) and a 1890 regulation limited library collections to material permitted in special, official lists. The first such list, however, came ten years later, in 1900. The overall chronology of lists starting from 1882 has been described in Veskimägi 2000 and Tamme 2009. To put it bluntly, the whole affair of this specific list was pathetic and was seen as such by its contemporaries also. Villem Reiman (1901) reminded the reader of the issues he considered important: "...in order for Estonian literature to be accessible everywhere and to be able to fulfil its sublime purpose, it is vital that Estonian publishers and writers would go down the road directed..."

In other words, Estonian literature has its sublime objective and publishers, writers (and libraries and readers) have an obligation to submit to it. Reiman's quote nicely elucidates the internal and societal relationships between reading and libraries on the one hand and an ideological object like „Postimees” (the main nation-building powerhouse at the time), on the other.

The lists that were published up to 1905 (seven in all, with different additions) exemplified the double functions a library list has: as the definition of 'proper' reading or a 'proper' library as expressed by its circle of readers and librarians and also, as a means of straightforward, external repression.

\section{Lists by public library promoters in the 1910 s}

The situation started changing rapidly. The next phase for Estonian librarianship was connected to Noor-Eesti (Young Estonia). This was originally a group of authors that then developed both political as well as aesthetically into a wide-scale modernisation movement during the Revolution of 1905 . However, library issues only became significant later, after the turmoil had abated and the „Noor-Eesti” society was officially founded in 1912. The society had a section for library management headed by Karl Einbund (he became Kaarel Eenpalu in

6 By Veskimägi's estimate (2000: 151-152), there were about 100 Estonian libraries in the beginning of the 1880s, all of which were founded by the local authorities and without explicit permission from above (i.e., the Ministry of Education, the Supreme School District or the Sinod). The number increased to roughly 150 by the mid-80s and then stopped. The change was brought about by the introduction and strict enforcement of rather repressive regulations for schools, societies, etc., starting in 1884-1885. 
1935), who was then a student of law but later became the Prime Minister. This stage of the library movement introduces two important issues: professionalisation and the private initiative.

Over the relatively short period from 1911 to 1914, Einbund published 3 books on librarianship and the formation of libraries, managed the compilation of an extensive recommendation list and wrote about 20 articles. He also lectured extensively all over the country and supported the formation of library societies. He based his library model on the United States (via Finland, Germany and Russia, by the sources of his publications) and promoted it with vigour. His strong conviction was that libraries should be managed by people with professional education and that new libraries should be controlled by privately organised library societies. The library committee hired a person to consult in all library matters, mainly the formation of societies. In a way, nation building was still the underlying, though very much foremost task of the library movement. The library committee of the Noor-Eesti society published two lists: a list of recommended books for libraries that cost 25, 50, 100 and 200 roubles in 1913, and another one as a kind of continuation of the previous work after the war, in 1922. The introduction to the 1913 list stresses the importance of diversity in library material. The American influence mentioned above can be seen, for instance, in the fact that only 40 per cent of the list is fiction, the rest is non-fiction. But, as also mentioned earlier, the importance of the committee and society lies mostly in the first manuals and the indefatigable advancement of actual, everyday library work.

\section{0s: the transition from private initiative to state lists ${ }^{7}$}

Recommendation lists were not a priority for library development for most of the 1920s. The two revolutions, the War of Independence and the birth of the Estonian Republic all brought about fundamental changes in practically every field of life. But direct connections to the pre-war period were clearly discernible in some cases, among these the development of public libraries. Karl Einbund continued his work even under the German occupation. As soon as peace was established, work started on adult education in general and libraries in particular. But real, private initiative soon gave way to quasi-governmental adult (popular) education structures, which definitely were a priority in the field at the time. The central, nation-wide management of libraries was handed over to the Estonian Education Association who worked in conjunction with the

7 The general library list compiled and published in 1928-29 was not compiled by the state authority. Nevertheless, the organisation in charge, the Estonian Education Association (Eesti Haridusliit), in many respects functioned as an agency of the state. 
Ministry of Education. Rapid development of the library network started right away and lists initially did not have any role in this. The focus was more on the formation of a network, training of librarians, library technicalities, legislation, and cooperation with other educational facilities. Reading was rarely divided into good and bad and some conspicuous attempts to do so were vehemently counterattacked.

The passing of the Public Libraries Act in 1924 is illustrative. Veskimägi describes the conflict between different political trends in detail (2000: 349353 ), the result being that the restrictive and controversial article 16 on immoral literature never made it into the final version. But after the attempted communist coup at the end of 1924, questions of morality, propriety and good books, as well as the libraries' role in them, were seen in an altogether different light. The change became discernible in 1927, when the General Congress of Popular Education discussions on libraries led to the acknowledgement of a need for lists (see E.Vender's Report of the Congress, Vender 1927). The first list was ready in 1929 and was published in the journal of the Estonian Education Association Vabaharidustö̈̈ as well as a separate publication (Vender 1929). This was the first one in a long series (cf. Tamme 2009: 156). Subsequently, an amendment to the Public Libraries Act of 1935 rendered the list and its sequels compulsory. But our attention here should not fall on the lists, themselves, but rather on the accompanying discourse, the backdrop.

In 1882, Grenzstein compiled his list for 'everyman', obviously presuming that the people selecting books for school libraries were in need of help. In 1928, everything had changed, but the list was still accompanied by the same sentiment. Vender writes in the foreword: “...but often and in many places the lack of the necessary mental power is felt..." (Vender 1929: 8). And, it has to be noted that the first, possibly instigating move towards lists came from a librarian, A. Sibul (Vender 1928: 40-42). In his speech at the Popular Education Congress of 1927, Sibul complained of the inadequate instruction for librarians and stressed the need to direct the reading of the general public. As I have written earlier, it is conspicuous (Tamme 2009) that librarians as a profession did not express any opinion towards the introduction of compulsory lists in the mid-1930s. The same attitude is also discernible in the earlier stages - librarians actually seem grateful that someone else comes and takes the necessary steps to direct the general public's reading. 


\section{Summary}

The important points:

1. The selection of library material is an issue of utmost importance. It bears directly on our core as Estonians, as an independent and historically dignified nation. Because we are what we read.

2. Readers cannot be trusted to make selections by themselves. Librarians should know better, but they actually do not and, consequently, the responsibility is handed over to select, appointed specialists.

3. In most cases, librarians tacitly agree to the previous statement. There are periods when they are on a shorter leash and there are periods when they make their own selections.

And still, the sources of tension are mainly the same as always: national pride, conviction over what is and is not proper for public reading, public libraries.

The control of libraries, both external and immanent, is evident and also most influential in the selection of material. The most interesting result from the previous analysis seems to be that during transitional times (for Estonia approximately $1905-1925$ ), society generally seems less willing for reading to be institutionally directed. But, be the cause relative peace or economic crisis, there are also times when the people with a sense of responsibility introduce reading lists. And this tends to create tension between stakeholders and readers. Directing reading through library lists is a complicated phenomenon and the real assessment of the function these lists play in society is far beyond the limits of this paper and of the field where a librarian normally works. Still, theoretical elucidation of at least some of the issues involved, like the connection to nation building, could, at some points of social development, give us or somebody else the necessary leverage to change something.

\section{References}

Black, A. (1996). A New History of the English Public Library. Social and Intellectual Contexts, 1850-1914. London and New York: Leicester University Press.

Black, A. \& Hoare, P. (2006). The Cambridge History of Libraries in Britain and Ireland. Cambridge: Cambridge University Press.

Eskola, E. (2004). Suositellut, valitut ja luetut. Kirjallisuus kirjastoissa 1918-1939. Acta Universitatis Tamperensis 1049. Akateeminen väitöskirja. Tampere: Tampereen yliopisto.

Grenzstein, A. (1882). Raamatukogud, Olevik, 19.10.

Hurt, J. (1939). Jakob Hurda kõned ja avalikud kirjad. Tartu: Eesti Kirjanduse Selts. Issakov, S. (1979). Tsaarivõimud ja Eesti raamatukogud. Looming, 12, 1740-1752. Jannsen, J. V. (1870). Riast. Laeno=ramatokoggo. Eesti Postimees, 29.10. 
Kreutzwald, F. R. (1869). Wõrrust. Paar sõnna koggokonna ramatokoggodest. Eesti Postimees.

Mäkinen, I. (2008). New Institutional Economics and Information History - Is There a Point of Contact?'. Library History, 24, 117-127

North, D.C. (2004). Institutsioonid, institutsiooniline muutus ja majandusedu. Tartu: Fontese Kirjastus.

Reiman, V. (1901). Eesti kirjastajatele. Postimees, 25.07.

Shera, J.H. (1949). Foundations of the Public Library: The Origins of the Public Library Movement in New England 1629-1855. Chicago: University of Chicago Press.

Soovitatavate raamatute nimekiri. (1922). Tartu: Noor Eesti Kirjastus', Raamatukogude Korraldusselts.

Tamme, A. (2009). Lists of Recommended Materials for Estonian Public Libraries 1882-1940: Progress and Lessons. In Library Spirit in the Nordic and Baltic Countries. Historical Perspectives. Tampere: HIBOLIRE.

Vender, E. (1928). Eesti II Hariduskongress. Vabaharidustöö, II-III, 34-47

Vender, E. (Ed.) (1929). Raamatukogudele soovitatavate raamatute nimekiri. [Tallinn]: Eesti Haridusliidu kirjastus.

Veskimägi, K.-O. (1964). Eesti rahvaraamatukogude õiguslik seisund XIX sajandi teisel poolel ja XX sajandi algul. Tartu Riikliku Ülikooli Toimetised, Töid eesti filoloogia alalt, 162. Tartu: Tartu Riiklik Ülikool.

Veskimägi, K.-O. (2000). Kahte kappi on ühhetassa majas tarvis: leivakappi ja ramatokappi: Eesti raamatukogude ajalugu. Tallinn: Kaljo-Olev Veskimägi.

Шира, Дж Х. (1973). Социологические основы библиотечного дела. Москва: ВИНИТИ. 


\title{
The reading preferences of Estonian adolescents
}

\author{
Helin Puksand \\ Introduction
}

In recent years, there has been increasing interest in students' reading habits. Lots of adults - parents and teachers - think adolescents do not like to read and do not read at all, but at the same time they forget what motivates adolescents. Dale H. Schunk, Paul R. Pintrich and Judith L. Meece (2009) define motivation as "the process whereby goal-directed activity is instigated and sustained." (p. 4) Estonian teachers assign lots of compulsory reading, but many adolescents don't like to read the books included on reading lists. If something is compulsory, it is automatically unpleasant, especially for youngsters, and it does not instigate any activity. Terri Flowerday, Gregory Schraw and Joseph Stevens (2004) emphasise that controlling the environment also reduces the student's sense of autonomy, decreases motivation, and results in poor attitudes and performance in the classroom.

This paper provides a brief survey of the empirical data related to the reading habits and preferences of adolescents outside school. The main questions of the paper are: a) what kind of books do Estonian adolescents prefer to read; b) what books do students enjoy; and c) what kind of media texts do adolescents read.

\section{Background}

Nowadays term literacy is defined as a social practice - something that people engage in on a daily basis in their homes, at work and at school (see Gee 2008; Pahl \& Rowsell 2005). The concept of reading literacy encompasses the range of situations in which people read, and the variety of ways that readers approach and use texts (OECD 2010b). Excellent reading proficiency at school has been proven to be the main factor for social success by the age of 21 (Bussière, Hébert, \& Knighton 2009). One of the factors affecting an 
individual's reading proficiency is his/her reading habits (Puksand 2012). By knowing a student's reading habits, teachers can motivate them to read and improve their reading skills.

One of the most powerful motivators is interest, and thereby we can identify the reading preferences of adolescents. If children are interested in reading they read more, and therefore, have more opportunities to improve their reading abilities than children who prefer not to read (Kirby et al 2011: 263). At the same time, we cannot forget that poorer readers have less interest in reading. Gay Ivey and Karen Broaddus (2001) stated that "students are expected to become independent readers, yet they get limited opportunities to explore their own interests in reading, to read at their own pace, or to make their own decisions about whether or not to read a book." Interest increases reading. Schunk, Pintrich and Meece (2009) point out that interest is not a type of motivation but an influence on motivation. (p. 237) Research has identified two types of interest: situational and personal/topic interest. Gregory Schraw, Terri Flowerday and Stephen Lehman (2001) maintain that situational interest plays an important role in capturing the students' attention, whereas personal interest is more important in maintaining it. Topic and situational interest increase positive attitudes about the text and promote several different kinds of personal engagement (Schraw \& Lehman 2001). The second important motivator is choice: it is beneficial because it increases learning, performance, and positive affect. Students who chose what to read reported significantly higher situational interest than those who did not (Flowerday, Schraw \& Stevens 2004). This fact shows that choice and interest are related.

Students who enjoy reading the most perform significantly better than students who enjoy reading the least (OECD 2010a: 30). The results of the PISA 2009 survey show that only $61 \%$ of Estonian 15 -years-old students enjoy reading: about one-third of the students read for more than 30 minutes a day, and a quarter read for enjoyment for 30 minutes or less (Puksand 2010: 49). If students read for enjoyment at least few minutes a day, their reading performance is significantly better than the performance of students who don't read for enjoyment (Puksand 2012: 154). Therefore, teachers and educators must determine how to make reading attractive and enjoyable for adolescents. This allows us to draw the conclusion that reading for enjoyment is an important factor in improving reading skills. The teachers' key task is helping students to enjoy reading. They must take account of both the students' personal and situational interests because these relate positively to their choice of future activities, memory, attention, deeper cognitive processing, as well as actual achievement and performance (Schunk et al. 2009: 233). If texts selected for reading are interesting (see de Beaugrande \& Dressler 2002), students enjoy reading and their reading performance should improve.

In the PISA 2009 studies, the types of texts that 15-years-old students read for enjoyment were also ascertained. For enjoyment, Estonian fifteen-years-old 
students read a lot of newspapers ( $80 \%$ of students) and magazines $(72 \%)$, but two to three times less non-fiction (32\%) and fiction (24\%); comic books come last (13\%) (Puksand 2010: 52). The relationship between reading material and reading performance has also been examined recently. The strongest correlations were found to exist between reading fiction and reading performance, and between reading non-fiction and reading performance; reading newspapers and magazines was quite weakly correlated to reading performance (Puksand 2012: 150). There are several possible explanations for this result. One is that the difference may be caused by text types. The texts in newspapers and magazines are quite short and are therefore easier to read than the long texts in works of fiction. Fictional texts are long and seem complicated; therefore, poor readers do not read them. Another reason may be that teachers - especially nativelanguage teachers - deal with fiction in their classes, and therefore the students might achieve better results if this type of reading were to become a habit. (Puksand 2012: 151)

\section{Material and Method}

A total of 914 students from 17 schools completed the survey in 2008 and 2009, including 479 student from $9^{\text {th }}$ grade and 435 students from $11^{\text {th }}$ grade. The mean age of the students was 15.6 years in $9^{\text {th }}$ grade and 17.6 years in $11^{\text {th }}$ grade. There were 497 girls (54\%) and 417 boys (46\%). In the analysis of this data, descriptive statistics were used.

\section{Results}

\section{Reading books}

There is very long tradition of researching school reading in Estonia, but it is important to know how much adolescents read voluntarily (see Flowerday et al. 2004). First of all, I wanted to know when adolescents read of their own free will. As shown in Figure 1, one third of the adolescents have read something recently; $19 \%$ have read during this school year; and 16\% have read during the last summer. $21 \%$ of the adolescents have read before: in the previous school year or even earlier. $9 \%$ of adolescents did not answer this question. If this last $30 \%$ read at least the compulsory books, the situation is not so bad. But it could be that these students do not read any books at all.

In Figure 2 we see how many books have the adolescents read in a year of their own free will. Almost $40 \%$ of the students have read between three and nine books, while one third of the students have read from one to two books in a year. Students in Estonia have to read an average of nine required 
reading books, and therefore, the total number of books that are read is probably between 10 and 18, which is quite a lot. Fourteen percent of the adolescents read even more. The problematic group is the $14 \%$ of students who don't read at all of their own free will. However, maybe they are at least reading the required reading books. Sandra Hughes-Hassell and Pradnya Rodge (2007) found that the students who did not enjoy reading preferred other activities: watching television, spending time with their friends, surfing the web or playing video games. I can guess that the non-readers in Estonia have the same preferences.

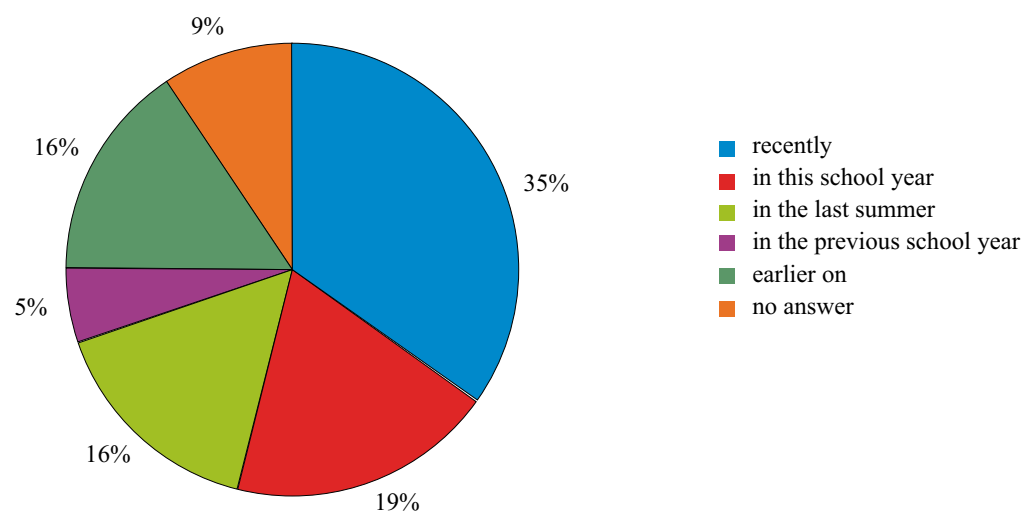

Figure 1. When did adolescents read of their own free will?

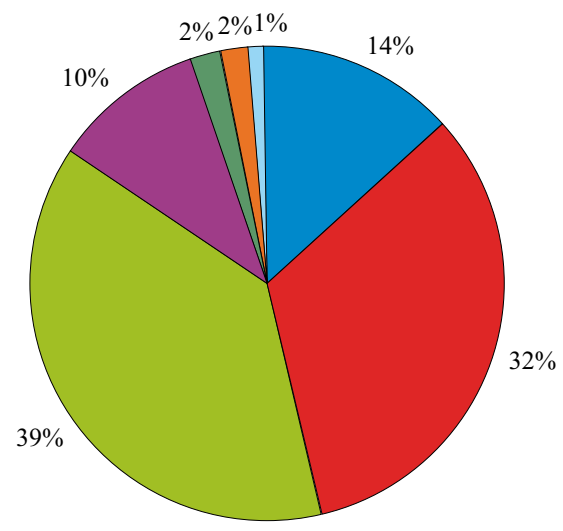

nothing

- 1-2 books

3-9 books

- 10-19 books

- 20-29 books

more than 30 books

no answer

Figure 2. How many books have adolescents read in a year of their own free will? 
What kind of books adolescents read is important. These results are shown in Figure 3. About half of the adolescents sometimes read reference books; $42 \%$ of students like comics and $41 \%$ like short stories. Eleventh-grade students and ninth-grade boys liked reference books the most. Results related to the reading of comics in the local study differed greatly from the PISA 2009 survey (see above) - only $13 \%$ of students read comic books. I guess Estonian adolescents don't read comic books but they read comics in the newspapers. Teachers also have a critical attitude toward the reading of comic books. Ninth-grade girls are the biggest readers of short stories. One third of the adolescents like to read novels and $28 \%$ like collection of short stories.

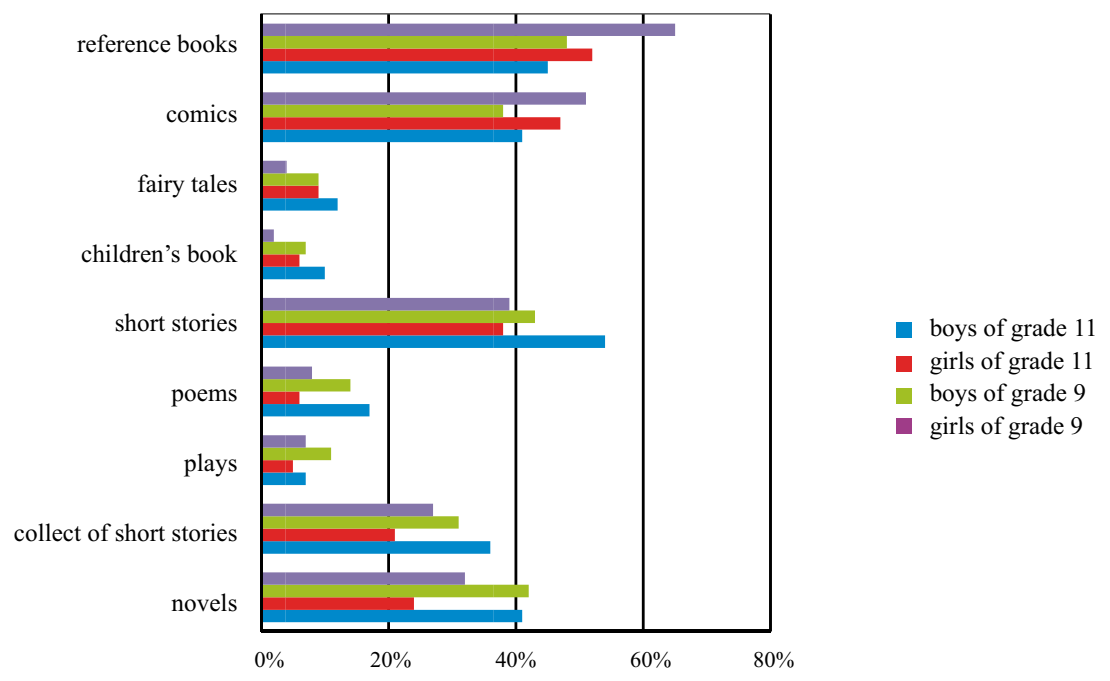

Figure 3. What kind of books do adolescents read?

I asked which book adolescents especially liked. The teenagers mentioned 453 books, and 160 books were mentioned more than once. The boys named 206 books and the girls named 337. Among the preferred books, contemporary literature dominated and the overwhelming favourite was Harry Potter by J. K. Rowling. The favorites of contemporary literature were ranked as follows:

- J. K. Rowling, Harry Potter, mentioned by 68 respondents ( 28 boys and 40 girls);

- Andrus Kivirähk, Rehepapp, mentioned by 41 respondents (20 boys and 21 girls);

- Aidi Vallik, How Do You Live, Ann?, What Do You Do, Ann?, What Happened to You, Ann?, mentioned by 40 respondents (1 boy and 39 girls);

- J. R. R. Tolkien, The Lord of the Rings, The Hobbit, mentioned by 34 respondents ( 26 boys and 8 girls); 
- Andrus Kivirähk, The Man Who Knows the Words of Snakes, mentioned by 34 respondents (15 boys and 19 girls);

- Sass Henno, I Was Here, mentioned by 34 respondents (13 boys and 21 girls);

- Dan Brown, The Da Vinci Code, mentioned by 22 respondents ( 9 boys \& 13 girls);

- Paolo Coehlo, The Alchemist, mentioned by 21 respondents (6 boys \& 15 girls).

Of the literary classics, the following books were the favourites:

- Anton Hansen Tammsaare, Truth and Justice, mentioned by 44 respondents (17 boys and 27 girls);

- Erich Maria Remarque, All Quiet on the Western Front, mentioned by 30 respondents (12 boys and 18 girls);

- Charlotte Brontë, Jane Eyre, mentioned by 23 girls;

- Fyodor Dostoyevsky, Crime and Punishment, mentioned by 22 respondents, (10 boys and 12 girls).

In the list of favourite books, we see many books from the schools' reading lists: Truth and Justice, Crime and Punishment, A Doll's House (by Henrik Ibsen), Anna Karenina (by Lev Tolstoy), Bye, Yellow Cat (a youth novel by Mati Unt), Eugene Onegin (by Alexander Pushkin), The Lord of the Flies (by William Golding), The Master of Kõrboja (by A.H. Tammsaare), and The Old Man and the Sea (by Ernest Hemingway). Many books were also student favourites in the previous years. For example, Jane Eyre, Truth and Justice, All Quiet on the Western Front, Crime and Punishment were also adolescent favourites in 2001 (Luhari \& Sõrmus 2001). The last three books were also on the reading lists in 2001. This fact confirms the importance of school reading lists because adolescents otherwise do not read these books.

Two hundred and thirty-four adolescents (102 boys and 132 girls) indicated who their favourite authors are. The teenagers mentioned 83 authors and 33 authors were mentioned more than once. Boys named 49 authors, and girls 56.

The most popular author is Andrus Kivirähk (20 mentions). Next in line is Anton Hansen Tammsaare (12), and Agatha Christie and Terry Pratchett were in third and fourth place, both being mentioned 11 times. The fifth most popular author is Paulo Coelho (10) who is a favourite of the girls. The other authors who were mentioned included Dan Brown and Erich Maria Remarque (9), J. K. Rowling and Friedebert Tuglas (8), Astrid Lindgren, Ernest Hemingway and Sass Henno (7), J. R. R. Tolkien and Kerttu Rakke (6), Honoré de Balzac, Kurt Vonnegut (5), Edgar Allan Poe, Isaac Asimov, Karl Ristikivi (4), Gabriel Garcia Marquez, Lev Tolstoy and Stephen King (3), A. Huxley, A. Vallik, A. Pushkin, A. Chekhov, C. Palahniuk, F. Dostoyevsky, F. Kafka, I. Hargla, J. Clarkson, L. Gardner, and U. K. Le Guin (2). 
Adolescents like books that are imaginative (e.g. Harry Potter, The Lord of the Rings), appealing and full of adventures (e.g. the previously mentioned books and Da Vinci Code). Adolescents also like humour (e.g. books of A. Kivirähk) and books about children who are the same age (e.g. Ann's stories, I Was Here). In addition, they like philosophic books (e.g. Crime and Punishment, The Alchemist) and culturally significant books (e.g. Truth and Justice, books by A. Kivirähk). In her article, Rosemary Hopper (2005) points out similar categories for making reading choices: prior knowledge of a book or author, the appearance of the book, recommendations, television or film, genre. Estonian adolescents did not mention the appearance of books, but other reasons were the same.

I wanted to find out what kind of books adolescents do not like. They mentioned 141 books. Almost all books that were listed as not being liked were also included on lists of favourite books. The books that are not liked are often included on reading lists: V. Hugo The Hunchback of Notre Dame (27 mentions), E. Vilde The Milkman from Mäeküla (20), A. H. Tammsaare Truth and Justice (20), H. de Balzac Father Goriot (19), M. Unt Bye, Yellow Cat (17), E. Hemingway The Old Man and the Sea (17), E. Bornhöhe Avenger (16), E. Kippel Meelis (15), J. W. Goethe Faust (14), F. Dostoyevsky Crime and Punishment (13), A. Pushkin Eugene Onegin (13), etc. Why don't adolescents like these books? Four students emphasised that all the books on the reading list are boring and unpleasant. The books that are most boring for adolescents are for example, Meelis, Bye, Yellow Cat, The Spring, Wikman's Boys, The Old Man and the Sea). Adolescents don't like long descriptions (e.g. "The Hunchback of Notre Dame", "Truth and Justice"). Sometimes adolescents are scared off by the thickness of the books (e.g. Crime and Punishment", Wikman's Boys, Greek Mythology). Students prefer exciting stories and some books move along too slowly (e.g. Truth and Justice, The Milkman from Mäeküla). Some student doesn't like books about war (All Quiet on the Western Front) or fantasy books (The Wizard of $\mathrm{Oz}$, Rehepapp). A reason why some adolescents do not like books could be that their reading skills are weak. Reading fiction may cause low self-esteem in weak readers resulting in a negative attitude towards reading.

\section{Reading at the computer}

Adolescents spend more and more time at the computer. Figure 4 shows that half of adolescents spend two to four hours their time at the computer. The answers given by boys and girls were the same. Twenty-two percent of the adolescents spend more than four hours at the computer. Twenty-seven percent of the boys and $18 \%$ of the girls chose this answer. Only 10 adolescents ( 5 boys and 5 girls) said they spend a couple of hours a month at the computer. These results indicate how important computers are for adolescents. 


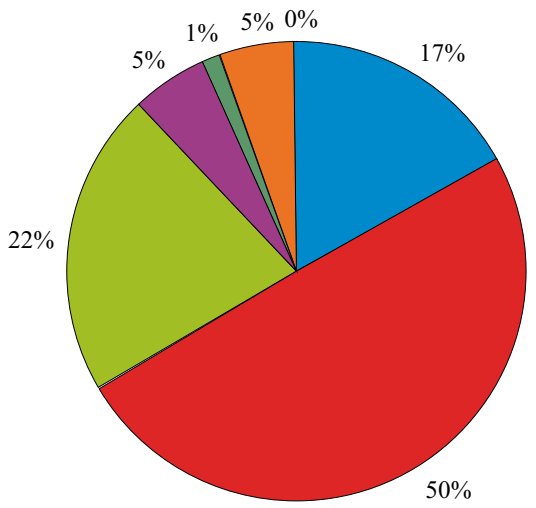

about an hour

2-4 hours

more than 4 hours

- some hours in a week

- some hours a month

- sth else

no answer

Figure 4. How much time do adolescents spend at the computer?

What do adolescents do at the computer? As shown in Figure 5, most adolescents communicate with friends $-80 \%$ of adolescents chose this answer. Girls communicate with their friends a little more than the boys do ( $86 \%$ vs. $72 \%)$. Other preferences are reading news, searching for information about my hobbies or for school, and reading and writing e-mails. Playing computer games was a less popular choice - only $22 \%$ of adolescents chose this answer. Boys like to play the computer games more than girls (39\% vs. $7 \%)$.

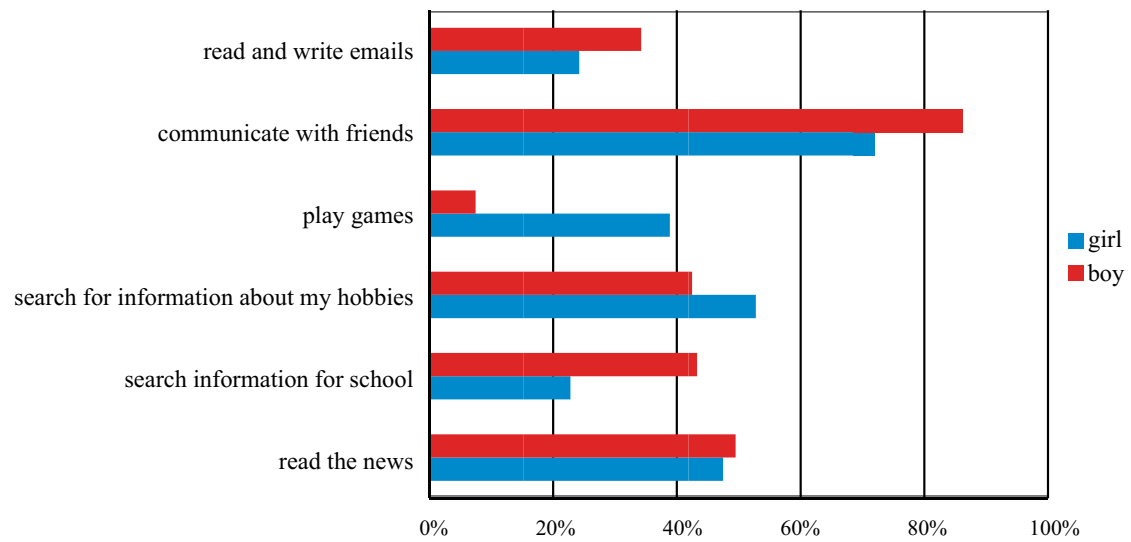

Figure 5. Actions performed by adolescents at the computer. 
A computer cannot be used without reading. Figure 6 indicates how much time adolescents spend reading at the computer. One third of the adolescents said they read most of time. Twenty-three percent of the students said they read half the time, and $17 \%$ said they read $75 \%$ of the time. Eleven percent of the students said they read all the time. Less than one fifth of the adolescents think they read less and there were only three boys who said they didn't read at all. Reading at the computer is automatic and these students do not realize that they are reading. My previous study pointed out that the relationship between reading performance and students' online habits is quite weak (Puksand 2012), but teachers can use the adolescents' personal interests to make reading more interesting.

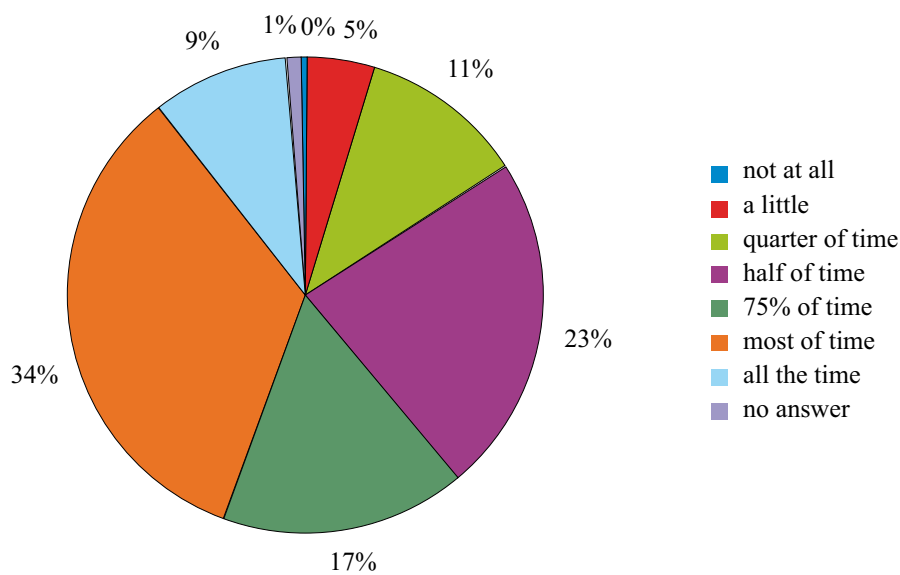

Figure 6. How much time do adolescents spend read at the computer?

\section{Reading other texts}

Adolescents read a lot at the computer. Figure 7 indicates the kinds of media texts that Estonian students read. They read MSN texts the most - nearly $90 \%$ of students read them at least couple of times a week. Interesting web texts are in the second place ( $88 \%$ of adolescents). SMSs are also popular (86\%). E-mails are read by $82 \%$ of adolescents. It's interesting that the same percentage of students read newspapers and newspaper websites (74\%). Almost the same number of students read information on social networking sites. Most popular among adolescents is the daily news (e.g. Postimees, Õhtuleht, and Päevaleht). Almost the same number of students read information on social networking sites. Girls prefer social networking sites (e.g. Orkut, Rate, Hot), but boys prefer read interesting web texts (e.g. Delfi, Google, YouTube) (Puksand 2011). 


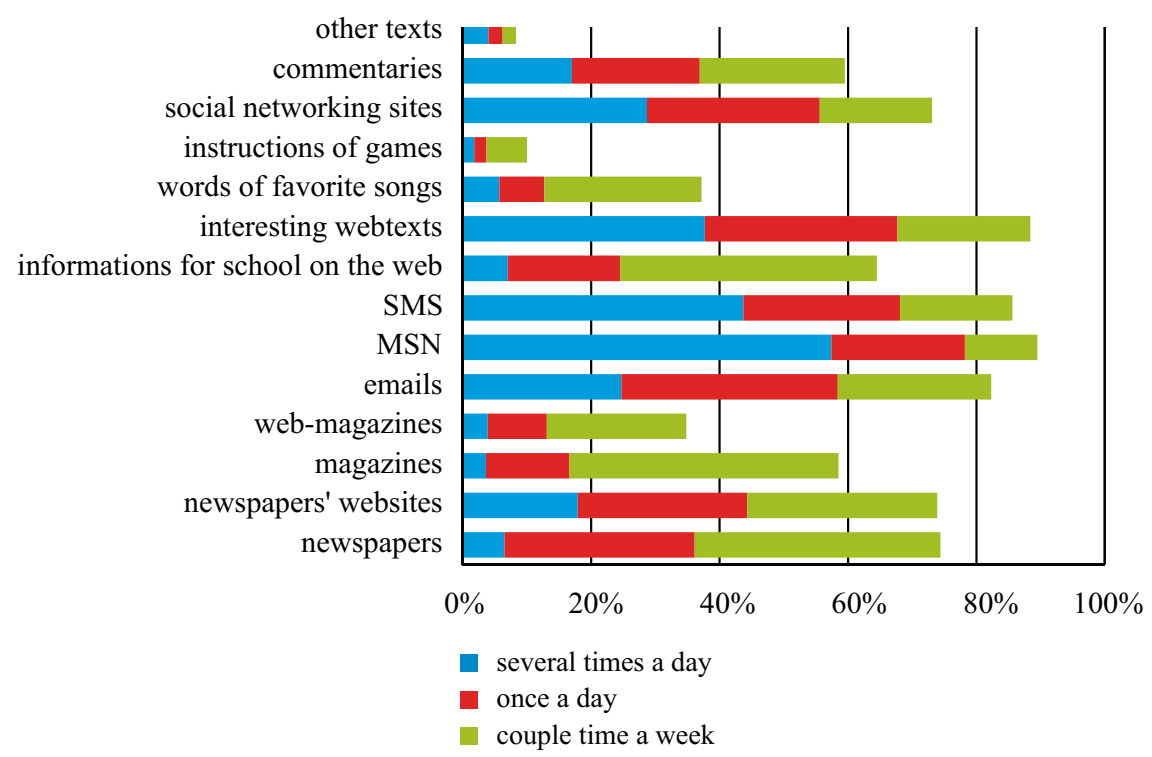

Figure 7. What kind of media texts do adolescents read?

There are also media texts that adolescents read less. Sixty-five percent of students read information for school on the web; $60 \%$ read commentaries. Fifty-eight percent of adolescents read magazines, but only $35 \%$ read web magazines. The reason is probably that web magazines do not have full-length articles. Girls prefer to read women's and tabloid magazine (e.g. Cosmopolitan Stiina, Kroonika), but boys like to read about technology and cars (e.g. Tehnikamaailm, Autoleht) (Puksand, 2011). Reading instructions for games and other texts is least popular among adolescents.

Students do not use computers very much for obtaining information for school. I think teachers should realize that using the computer could be a key component in shaping adolescents' reading habits.

\section{Conclusions}

This study has shown that Estonian adolescents read quite a lot - they read both books and other texts. Literature lessons play a significant role in shaping students' taste in literature, because they would otherwise not be exposed to many good books. On the other hand, teachers must take the ages and abilities of the students into account. Hopper (2005) emphasises that in order to give adolescents access to a range of texts we also need to understand what prompts their choices. Estonian adolescents prefer read texts that are interesting, imaginative, 
exciting, and humorous; also important is knowledge about the book and the author, and the possibility to philosophise.

Reading at the computer is becoming ever more important in everyday life and adolescents spend a lot of time at the computer. Adolescents read different type of media texts: news websites, other interesting websites and social networking sites. Adults should understand that reading is not just reading books. James Paul Gee (2008) maintains that the following are crucial for success now and in the future: the ability to deal with multimodal texts (texts which mix words and images), nonverbal symbols, and technical systems within specific, and usually highly collaborative, institutional practice (p. 40). There are multimodal texts in the computer and adolescents use them every day. Gee (2008) points out that those different types of texts (e.g. newspapers, comic books, physics texts, math books, novel, poems, advertisements, etc.) call for different types of background knowledge and require different skills to be read meaningfully (p. 43). Therefore adolescents should come in contact with different texts, including multimodal texts, at school.

\section{References}

Bussière, P., Hébert, R., \& Knighton, T. (2009). Educational outcomes at age 21 associated with reading ability at age 15. From Statistics Canada: http://www.statcan. gc.ca/pub/81-004-x/2009002/article/10896-eng.htm Acessed 16 Oct, 2013.

de Beaugrande, R.A., \& Dressler, W. U. (2002). Introduction to Text Linguistics. London: Longman. (Digitally reformatted.)

http://www.beaugrande.com/introduction_to_text_linguistics.htm Accessed 13 Nov 2013.

Gee, J.P. (2008). Linguistics and Literacies: Ideology and Discourse. London: Routledge.

Flowerday, T., Schraw \& G., Stevens, J. (2004). The Role of Choice and Interest in Reading Engagement. The Journal of Experimental Education, 72 (2), 93-114.

Hopper, R. (2005). What are teenagers reading? Adolescent fiction reading habits and reading choices. Literacy, November 2005, 113-120.

Hughes-Hassell, S. \& Rodge, P. (2007). The leisure reading habits of urban adolescents. Journal of Adolescent \& Adult Literacy, 51 (1), 22-33.

Ivey, G. \& Broaddus, K. (2001). "Just plain reading": A survey of what makes students want to read in middle school classrooms. Reading Research Quarterly, 36 (4), 350-377.

Kirby, J. R., Ball, A., Geier, B. K., Parrila, R. \& Wade-Woolley, L. (2011). The development of reading interest and its relation to reading ability. Journal of Research in Reading, Vol. 34 (3), pp. 263-280.

Luhari, B. \& Sõrmus, E. (2001). Õpilane. Raamat. Raamatukogu. [Student. Book. Library.] Tallinn: Riiklik Eksami- ja Kvalifikatsioonikeskus. 
OECD (2010a). PISA 2009 Results: Learning to Learn - Student Engagement, Strategies and Practices (Volume III). http://www.oecd.org/pisa/pisaproducts/48852630.pdf

OECD (2010b). PISA 2009 Results: What Students Know and Can Do - Student Performance in Reading, Mathematics and Science (Volume I). http://www.oecd.org/pisa/pisaproducts/48852548.pdf

Pahl, K. \& Rowsell, J. (2005). Literacy and Education. Understanding the New Literacy Studies in the Classroom. London: Paul Chapman.

Puksand, H. (2010). Lugemine. Lugemis- ja õpiharjumused. [Reading. Reading and learning habits.] In G. Tire, H. Puksand, T. Lepmann \& I. Henno (Eds.), PISA 2009 - Eesti tulemused. Tartu: HTM.

Puksand, H. (2011). Eesti koolinoorte lugemisharjumused meedia näitel. [Estonian Adolescents' reading habits using the example of media.] In H. Metslang, M. Langemets \& M.-M. Sepper (Eds.), Eesti Rakenduslingvistika Ühingu aastaraamat 7. Tallinn: Eesti Rakenduslingvistika Ühing.

Puksand, H. (2012). Reading habits of the Estonian adolescents - the basis for lifelong learning. In J. Mikk, P. Luik \& M. Veisson (Eds.), Lifelong Learning and Teacher Development. (Estonian Studies in Education 4.). Frankfurt am Main: Peter Lang.

Schraw, G., Flowerday, T., Lehman, S. (2001). Increasing Situational Interest in the Class-room. Educational Psychology Review, 13 (3), 211-224.

Schraw, G. \& Lehman, S. (2001). Situational Interest: A Review of the Literature and Directions for Research. Educational Psychology Review, 13 (1), 23-52.

Schunk, D. H., Pintrich, P. R., \& Meece, J. (2009). Motivation in Education: Theory, Research, and Applications. Upper Saddle River, NJ: Pearson/Merrill Prentice Hall. 



\title{
V. LIBRARY PRACTICES AND EXPERIENCES
}

\section{"Time is out of joint": A postmodern approach to libraries}

\author{
Olga Einasto
}

\section{Introduction}

As a socio-cultural institution, libraries have always reflected the changes taking place in the society. Since our society has changed very radically during the last decades, it is difficult to understand contemporary libraries within traditional frames. The changes are not related only to the development of information technology, the extremely rapid distribution of information and the materialisation of books, but also to significant changes in culture, philosophy and worldview.

Libraries, which based on their nature, are amazingly modernist institutions exist today in societies bearing different names - in post-industrial, information, service, risk, and certainly also postmodern societies. Under these new social conditions, the necessity arises to analyse what is happening in libraries today, and to analyse new phenomena in the philosophy and practices of libraries. The new postmodern reality in our libraries requires a postmodern approach. Below, we attempt to view the modern library based on the categories of postmodern philosophy.

In our analysis of the changes occurring in libraries, we are interested in analysing postmodernity as:

- a historical and cultural situation of the society (Lyotard 1997),

- a condition or a state of being associated with changes to institutions and creations (Giddens 1990),

- a general worldview through which the main tendencies and cultural changes of present-day society are expressed,

- the social context in which libraries develop as socio-cultural institutions.

Alan Kirby's concept of digimodernism seems especially interesting in regard to library services. In his opinion, the new cultural climate has been 
reconfigured by digitisation (Kirby 2009). Kirby primarily relates digimodernism to the proliferation of the Web 2.0 platform, along with Wikipedia, blogging and social networks, in the early $21^{\text {st }}$ century (Ibid). Digimodernism also means an active interaction between authors, readers and web-users, as well as the democratisation of culture (Viires 2013). Cultural institutions are also becoming democratised and libraries are no exception. The main changes in libraries caused by digimodernism are the technological leap and the use of Web 2.0 opportunities, including blogging, by the librarians and the presence of libraries on Facebook, Twitter, and VKontakte.

Marin Laak (2013: 85) has stressed that cultural transformation processes and the new digital media have influenced the creation and consumption of culture, but have also opened up new directions for memory institutions - the museums, archives and libraries preserving traces of the past. And, it should be added, also for creating the library services of the future.

\section{Postmodern phenomena in the new library science and services}

\section{Variety and pluralism vs. meta-narratives}

The history of human civilisation is a history of development; each generation learns from the experience of earlier generations, making their own achievements and contributing their work to the knowledge to be inherited by the next generation. In that learning process - a process that goes on throughout our lives - libraries can play a very important role. They preserve the meta-narratives - the written memory of our civilisation, a memory which mankind has developed to be more reliable and permanent than the oral tradition (Friend 1998).

Meta-narratives had incomplete views of social reality (LeMoine 2012). Western society was based on the assumption that there is a truth beyond us, which is documented in literature and history, but now rationality, objectivity and universal truth are rejected (Ibid). According to Kruk (2002), there is no truth, there are no good books or bad books, and no one has the right to make such judgements. No group of people can claim that they know what reality is. We apparently do not discover meaning but create it. Postmodern librarians do not pay much attention to collection development. Reading is not a serious undertaking and does not lead to the discovery of truth; rather, it is a distraction.

Librarians have their own specific meta-narratives: the bibliographical control of knowledge and the universal classifications for systematising it. Thereby, librarians control reality, describing it in catalogues, keeping the dozens of classificatory numbers and punctuation marks of the entries in their heads, regardless of whether the entries are on paper or in an electronic catalogue. 
At the same time, library classification systems are not very compatible with the postmodern worldview, because universal classifications as logical hierarchy systems were a product of the Modern Era. According to LeMoine (2012), these are the great narratives for librarians, since those systems represent reality for them. In addition, libraries can use the classifications to demonstrate their power, or even, as LeMoine says, "for discrimination".

In the postmodern era, meta-narratives were replaced by pluralism and variety. Lyotard (1997) spoke of variety as an almost obligatory principle, stressing that this is an essential part of our being, which provides everyone with the right to be and develop. This is a postmodern idea. And this postmodern approach is clearly visible in the various collections of a modern library, where everything manuscripts, publications, audio-visual items, microforms and electronic information - belong. Naturally the development of libraries has always been related to the evolution of data carriers (papyrus - paper - microfilm - audio-visual carriers - CD-ROMs - e-books), but revolutionary developments in the process have occurred twice in the history of libraries: in the $15^{\text {th }}$ century in connection with the invention of the printing press; and in the $20^{\text {th }}$ century when information started to be stored and made available in electronic form.

The items in our various collections "peaceful coexist" and are reflected equally in the catalogues. Our readers use both traditional and electronic services. To find a book one can use either the electronic or card catalogue. And a new and very postmodern and pluralistic term - hybrid libraries - has become popular in library science today. This term defines the modern libraries that combine the functions of traditional libraries and IT-based libraries, without favouring one over the other. At this point, it is important to mention that when speaking about digimodernism, Alan Kirby also points out such phenomena as hybrid texts and hybrid audiences (Kirby 2009). In a similar way, the contemporary hybrid library could be called a hybrid organisation as it combines both modern and postmodern categories and ideas.

\section{Chaos vs. order}

Modern social order means the constant opposition of chaos and order; the preference for order and the constant search for disorder and the deterrence thereof (Postmodernism 2002). Above all, modernity meant creating rational order with the help of science. Reason creates science; science in turn creates order. Order is the guarantee of every institution (for example, a library) and its activity in its best (rational) form.

In our contemporary postmodern culture neither order nor stability is that important, because postmodern culture does not deem it necessary to keep its ideals, traditions, and stability constant. Questioning everything could be considered to be the central idea of postmodernism. To view the library in this context of chaos and instability is not an easy task. 
Throughout the centuries, libraries have essentially been stable cultural institutions based on constant traditions. At the same time all principles and values of a library are amazingly modern. In the history of human culture, libraries have always been structured and classified collections of documents. They have been characterised by a definite system and order - above all by the organisation of collections and catalogues. Libraries can never attain absolute disorder. Quoting J. Borges (1972), "If an eternal traveller should journey in any direction, he would find after untold centuries that the same volumes are repeated in the same disorder - which, repeated, becomes order: the Order".

The main aspiration of a library has always been to systematise plurality and to make that system visible through its catalogues. According to Ford (1994), the library owes this attribute to the Age of Enlightenment, although monastery libraries systematised their collection already in the Middle Ages. At the same time, it was during the Renaissance that the ideas of subordination and dominance came to be respected and this was also reflected in the activities of libraries.

The easiest and simplest way of obtaining the desired order was to institute classification. Since that time strict classification has formed the core of a library's organisation. The first systematic catalogue appeared in the late Middle Ages, between the $13^{\text {th }}$ and $14^{\text {th }}$ centuries. About the same time, libraries started using call numbers to arrange their books on the shelves. University libraries were ordered according to their faculties and divided according to the sciences as trivium (grammar, rhetoric, and logics) and quadrivium (arithmetic, geometry, music, astronomy). An alphabetic catalogue was born in the $16^{\text {th }}$ century. However, the year 1791 became the turning point for libraries when the French libraries became the first in the European history to institute cataloguing. A little later, in the 19th century, when the classificators were developed for sciences, subject indexes became to be compiled (Ibid).

This "modern" approach to the world of information has been successful for hundreds of years. According to Greenberg (1998), it is no wonder that librarians keep trying to organise the electronic information environment; the "elegant, hierarchical, and logical simplicity" of the library's traditional system has served us well and is likely to do so for a long time to come. Thus, above all, present-time postmodern cataloguing and categorisation also uses the principles of the modern era. Both large and small Estonian libraries still use modernistic classification systems, like the classification of the U.S. Library of Congress, the Dewey Decimal System, or the Universal Decimal Classification (UDC) for both books and e-books.

Postmodernism does not respect order and disorder. Closed sacral repositories, where librarians kept the collections in absolute order, have been replaced by open shelves where the reader can independently search for books and return them to their places. Therefore, the perfect order described by Borges cannot be guaranteed. However, that does not mean that libraries in the postmodern 
age have chosen chaos. It has always been essential for libraries to quickly find the books needed by the readers. That is why we still aspire towards a situation where all the books are catalogued and have call numbers; that is why checking the location of books, ordering, and taking stock of the collections is an everyday practice at libraries. And orderly organising and keeping the collections, in order to guarantee that the readers have quick access to the necessary books, is also one of the most important values and working principles in the postmodern era.

\section{Collections vs. access, consumerism}

Yesterday's libraries were defined primarily by their collections. In the modern age special attention was paid to the search for the original and preserving it. This was the primary function of libraries throughout the centuries. Thus modern libraries were centred on their collections and books. In the postmodern age, the original no longer has any importance as information can endlessly be copied while incurring almost no expense. In the postmodern library the focus is on the reader as the user and the process of rendering the service. For today's libraries, it is not important to own the original information source but to know where it is and how to access it. Electronic document delivery and E-Book on Demand services have become very important. Therefore, libraries do not try to become the owners of information sources, as they know that they can be acquired as e-copies from the network of partner libraries.

An interesting fact is that as early as the Middle Ages libraries started using two approaches to organising their work. The first was based on a philosophical system and came to be reflected in the perfect categorisation of books based on scientific classifications; the other held that simplifying working with books was more important - they should be placed as conveniently as possible and the utilitarian aim should be to make them more accessible. The latter approach forms the basis for the majority of ideas related to the current architecture of libraries and also provides the grounds for developing postmodern ideas. The new paradigm of library science with its reader-centred approach is based thereon.

Libraries now pay much more attention to the keyword of "access" - on how to make the collections more accessible for the user - and not on how to organise them. The library and reader services are now based on the users' needs. Thus, the new library paradigm is comprised of a reader-centred model of library science where the barriers between the library and its users disappear; a postmodern library is a "fusion of the library and user" (Stone 2000).

It is in the postmodern era that libraries started a marketing discourse. The readers started to be spoken of as clients at the end of the 20th century; communications between the librarians and readers started to be called a service; and the active development of marketing plans and projects was initiated. Libraries got new specialists - marketing directors and organisers of 
marketing communications. The users started to be divided into target groups whose expectations and wishes were studied. This happened because, in the postmodern era, information has become a commodity. It is very important to offer it at the right time, in the right way, in the right place, to the right person. In this regard, libraries must compete with other informational institutions and the Internet. The key phrase for consumerism - the client's contentment - is now a very important factor in the financing of libraries. The readers have also become very demanding, by using their rules and rights as clients when communicating with the library.

\section{The changing environment related to library services}

The relativity of the world as a definitive feature in postmodern societies has also affected the library services. This is primarily reflected in the virtualisation and disappearance of barriers. Using the keywords of postmodernism, a virtual library could be called a matrix of a real library. However, if in postmodernity the real world does not have any advantages over the matrix, we could say that a real library still has one advantage over a virtual one - this is a real place where "genuine" communication between people can take place. We can also see that our users are not willing to give up this advantage despite the convenience of using library services without leaving home. So the library as a physical place has not been lost in the postmodern and digimodern age. To the contrary, new library buildings designed by the best architects are being built all over the world.

There are large conference and lecture halls, quiet reading rooms, and rooms for group work in today's libraries. People are still using libraries rather actively in the postmodern age. True, not always for obtaining the traditional library service - getting information. Students appreciate the study environment of academic libraries, which is why the University of Tartu Library is open at night during the examination periods and many U.S. college libraries are open 24/7. More and more, public libraries are becoming places for meeting and communicating. But let's not forget that modern age libraries, as a place of enlightenment, were also places where people met, discussed things, argued, and communicated. Thus this clearly modern phenomenon has not become lost in the postmodern age; while the library may look different, its role as a place of ideas, learning, community, and open access to information is still intact. While online communities are easy to find, there is still the need for a physical place where one can read, study, research, collaborate, and get something for free (LeMoine 2012).

Another important postmodern keyword is decentralism. The way of thinking, which was prevalent in the modern era, was primarily expressed in the strictly hierarchical order of organisations. The current trend is a networking structure. The process of networking libraries started in the 1970s and was caused mainly by the flood of information and limited resources. The process 
accelerated in the 1990s with the proliferation of the Internet that allowed libraries to be used without the user being physically present. Today, scientific journals have started offering their publications mostly through the Internet. Scholars wish to access the maximum amount of information from their workplace. Students increasingly prefer the networking environment. Thus library services are no longer defined by a single building; they can be used at home, at the workplace or anywhere that has a computer and an Internet connection.

I would like to stress the postmodern decentralisation in the work of a library has nothing in common with anarchism, as decentralism does not exclude the process of integration. A good example is development of the Group of Estonian Library Network ELNET. Contemporary library systems make it possible to connect many libraries into a common network at the same time. These integration processes are postmodern in nature, as they do not need to be governed by a definite centre; above all, this integration means coordinating activities. Thus the aim of the ELNET Group is to coordinate legal, financial, and technical questions. The libraries of the Group use an integrated information system and one of the results of their cooperation is the common electronic catalogue called ESTER, which describes the book collections of all the member libraries.

\section{Skills vs. knowledge: transforming library services}

In the postmodern era, education becomes very functional: nothing is studied only to acquire knowledge but to apply that knowledge. In this respect library education is no exception. Today more emphasis is placed on developing skills than on general education. This is partly based on the fact that the quantity of knowledge and information in libraries has enormously grown. Thus, currently, knowledge that is fluid is appreciated the most.

One of the most drastic changes for libraries in the postmodern age is that librarians can no longer present themselves as experts. Expertise is always related to some universal truth. However, this is a modern idea and does not correspond to the postmodern worldview. In the modern era, libraries were the only places where one could get the answers to practically all questions. The role of the librarian was to guide the reader in his or her path to information from questions to answers, from ignorance to knowledge. Many people saw this path as a complex labyrinth because a great deal of professional knowledge and specific professional skill were necessary. In this labyrinth, the librarian resembled Ariadne, whose position was inevitably authoritarian; the dialogue between the reader and the librarian was hierarchical with the librarian looking down at the reader.

Today librarians can no longer monopolise the right to information. Our professional knowledge does not seem sacred to society. Libraries can longer exert power with the help of knowledge; they have to hold a dialogue of equals with the reader. 
This situation has become particularly apparent in the $21^{\text {st }}$ century with the onset of digimodernism. The Web changes the conceptions of knowledge production and use. Google demonstrates how easy it is to get information, and how quickly one can find the answers to questions. The open information culture, as exemplified by Wikipedia, attests to a dramatically altered conception of knowledge as something that is produced, not solely by experts, but through a convergence of many people who bring knowledge or experience to bear on a subject. Knowledge that is fluid, and even imperfect, is more valuable today than knowledge that is perceived as static and intact. Data that can be copied, pasted, mixed, adapted, recast for evolving purposes and new modes of understanding has very strong appeal in today's information environment, particularly for young people. The problem of managing and preserving knowledge produced in these shifting realms of digital proliferation is enormous, and it is one that librarians need to be integral to solving (ACRL 2006).

All this comes into conflict with the classical library service - the reference service, as this was always based on the knowledge of an information expert. Some libraries are already giving up offering that service; and bibliography departments are being disbanded. And recommended bibliographies are already viewed a being relics from the past.

Martin found that it is important for library services not only to examine the fact that people do not consider libraries to be portals of information, but also the fact that today's users see themselves as being capable information seekers (Martin 2009). They have been conducting online searches almost since kindergarten, but they do not comprehend the chaotic nature of online information. They may feel that using library services requires more efforts and skills than searches on the Internet. While we, librarians, see the power of our databases and catalogue options, such as Boolean operators, the users see them as obstructions. And when our self-confident users fail in their library searches, they are left feeling confused and frustrated with the library (Ibid). What can we do? The promotion of information literacy training as a basic library service is very important today. Quite naturally, today's bibliographer finds it difficult to compete with Google, Wikipedia and computer memory. If, in the modern era, bibliographers answered the enquiries of the readers, searching for and offering useful and relevant information, now, instead of bibliographic instruction, librarians engage users in information literacy training. As Martin stressed, "we can encourage information literacy while embracing postmodernism; information literacy is about exploration, not information control" (Martin 2009: 6). Postmodern librarians must make users aware that our collections exist for the express purpose of sharing the different opinions, theories, and truths which postmodernism values, as an almost playful place where not one idea dominates (Ibid: 7).

Commenting on some cases of librarians clinging to an authoritarian metanarrative, Lankes observed, 


\begin{abstract}
"This resistance to the democratisation of authority among librarians is ironic because there are few professions better suited to the authoritative world of the Internet than librarians. They have a culture of open and free expression and access to ideas. They are generalists who move agilely across different topical domains. They are skilled at searching out information, and locating potential biases (and uses) in information. Their enterprises (i.e. libraries) have little invested in the production of information, and much invested in the consumption of information products from a wide variety of sources. Further, librarians already have a reputation as authoritative, not authoritarian" (Lankes 2007: 679).
\end{abstract}

The postmodern user does not need an information expert or priest, so the reference librarians must allow students to explore and evaluate resources on their own, with guidance from librarian as their helper.

\title{
Discussion
}

As we have seen, the arena in which knowledge and ideas are created, shared and documented - the librarians' arena - is undergoing a transformation of unusual scale and impact, which is equivalent, or perhaps even greater, than the invention of the printing press (Kaufman 2005). It is clear that the Internet and online information introduced many postmodern values to the library, such as consumerism, hybridity, decentralism, and chaos. Libraries and the librarians now find themselves asking a series of fundamental questions. Does our postmodern society mean that we have to give up all our meta-narratives? How do we fit in new phenomena while not losing the values that are important to the library and the librarian? What new roles will librarians acquire in the changing information environment? What aspects of library philosophy and practice will prove the most resistant or impervious to change?

Ray (2001) found that postmodern libraries now need to be more flexible organisations with open boundaries; they should focus on their missions, learning and relationships. Here are some concepts that may be also important to the postmodern library and its services:

\section{- Re-thinking the classical library services}

The function of libraries has always been to guide users to information. The Internet is one of the most important factors that have changed the face of libraries. Today, for many people, Google and Wikipedia are more important and comfortable information portals than library. If librarians are no longer information experts, how should we perceive their new role? Of course, librarians can help users to understand the value of the materials preserved and digitised by libraries. The subject expertise of the librarians should also be developed and used to foster public engagement with the library collections. 
For example, as the ACRL (2006) agenda stresses, the culture of libraries and their staff must go beyond a mindset focused on ownership and control to one that seeks to provide service and guidance in more useful ways, by helping the users find and use information that may be available in electronic form through a range of providers, including the libraries themselves.

Davis (2008) argues that the values of neutrality, rationality and objectivity can be deconstructed for librarians who continually make value judgments in the course of 'evaluating' information sources and determining what are 'good' and 'bad' materials or websites for users; and the librarians should redefine their role in order to assist in the establishment of a truly equitable society.

The image of library services must be more postmodern and less didactic by guiding users away from postmodern chaos and teaching them how to evaluate information. For example, Harley et al. stressed that the value of a library is not so much in how many resources are offered, but in the nature of the services, activities, and programs it provides. The task of the academic librarian is to facilitate the students' critical thinking skills, not to teach them our tedious classification systems (Harley et al. 2001). LeMoine (2012) also found that postmodern library users know how to search and locate information, but have huge gaps in critically thinking about the nature and origin of this information, and this is where librarians are desperately needed.

\section{- Creating the new role and value of library}

Political support has always been essential for libraries as social institutions. It is important for librarians to understand how our society and users are transforming. It is necessary to react flexibly to the changes in society and to go along with them, as well as to create a mission and role for libraries in today's information society. And librarians need the courage to stand for their values. According to LeMoine (2012), librarians are the ones who seek to hear the voices of the "others" lost under the domination of meta-narratives; so the library structures and format change, but the postmodern library will continue to allow many narratives to be told. "Our place is that of fellow traveller, not tour guide; fellow student, not scholar; adventurer, not expert; and lay, not clergy. We are no longer experts, but we still know the value of information, with its origins and narratives" (ibid). The mission of the postmodern library must be to provide barrier-free access to quality information in support of reading, research, learning, teaching, and service to the society. By becoming cultural centres an expansive role can also be provided for libraries in the future. Thereby, libraries will not only serve as information resources, but as much more, with the exact mission and goals evolving and changing over time.

The dominant factor in the development of libraries is the ongoing trend towards the digital distribution of information through the global network infrastructure. This implies a shift from the traditional role of the library towards a role as a supplier of networked services for digital information resources (Owen 1997). 


\section{- User involvement: from user to participant}

The library of the modern era was centred on its physical building and the book collection. The readers of the digimodern era increasingly use the library online, as well as utilising the capabilities of the Web 2.0 platform. And the readers are empowered media users, who control and shape content, by evaluating the books they have read, and sharing their reading experiences with other users on the library website.

Rather than seeking dominance and control, postmodern leaders need to focus on integration. According to Bruun (2011), today most libraries have a more relaxed and natural way of interacting with digital possibilities - now the use of digital media and digital services is viewed more as a useful tool than as a threat to the libraries. The libraries have realised that even though the users aren't library experts, they are experts in being users. This in turn means that the libraries can acquire a great deal of knowledge and valuable information from their users. User involvement in digital projects means the creation of a new type of library service and interaction between libraries and their users. The users can help shape the library space and services more directly by using the tools and methods which are common in digital culture. This in turn can create new places for dialogue between the library and the user.

\section{Conclusions}

Naturally, there are many aspects related to this topic that could be discussed, but according to postmodern philosophy this paper presents only a fragmentary survey of how postmodernism has changed and is changing libraries.

In our contemporary libraries, modern categories (such as valuing and preserving the printed word, order in organising catalogues and collections) and postmodern ones (pluralism, variety, virtuality, disappearance of barriers, and participation of the reader) have merged. A postmodern library is a creative mix of old and new, of tools and resources, blending digital and printed books, and staff expertise in new and ever-changing arrays. A postmodern library is not an antithesis of a traditional modern library but has a different paradigm. The differences between the modern and postmodern belief systems can be illustrated by the following dichotomies: 


Modern library
Stability
Collection-centred
The object and subject of activity
Closed repositories
Order
Librarian as the source of information
Answering enquiries
Service at the library building
Homogeneity
Meta-narratives
Centralised control
Linear hierarchical structure
Clear boundaries, reality
Clear identity (mission of libraries)
The original and the sacred meaning thereof
Preservation of the original
Knowledge
Bibliographer as an expert

Book, linear text
Postmodern library

Fluidity, flexibility

Reader-centred

Process

Open collections

Order

Self-service, reader participation

Information literacy training

E-services online

Diversity, hybridity

Pluralism

Coordination, decentralism

Network structure, integration

Relativity, virtuality

Vagueness of the identity and

mission of the library

User copy, global access

Digitalisation of the original

Skills

Consultant as an assistant, reader participation

Multimedia, hypertext

The postmodern library is a new hybrid organisation primarily using new technologies and means of communication to get, systematise and make information accessible on different carriers. The libraries of the digimodern era are characterised by the love of technology. Computer technologies have drastically affected library philosophy and practices, thus the concept of librarianship and its practices have changed considerable. The library has today has become a rather flexible information and cultural institution with vague virtual barriers and access-centred mission. A postmodern library is a client-driven library; it researches and understands the users' needs and expectations. Moreover, users may play a key role as co-creators of new library services.

Today, librarians should not only diligently use new technologies but also have a deeper understanding of postmodernism, the information society and social transformations. This understanding will help in the creation of a library mission and the design of new services. 


\section{References}

ACRL. (2006). Changing Roles of Academic and Research Libraries. URL http://www. ala.org/acrl/issues/value/changingroles (20.10.2013).

Borges, J. (1972). Paabeli raamatukogu. Hargnevate teede aed. Tallinn, Loomingu raamatukogu, 5/6.

Bruun, S. (2011). Denmark User Involvement in Digital Library Projects. Making the Global Local. URL http://slq.nu/?article=denmark-user-involvement-in-digitallibrary-projects-making-the-global-local (20.10.2013).

Davis, C. (2008). Librarianship in the 21th Century - Crisis or Transformation? Public Library Quarterly, 27 (1), 57-82.

Ford, S. (1994). The Disorder of Things. URL http://www.nsys.by:8101/kinamen/dunaev/html(15.09.2013)

Friend, F.J. (1998). Mission and Purpose of Academic Libraries in the 21 st Century. In Proceedings of the International Conference on New Missions of Academic Libraries, Oct. 25-28 1998, Beijing. URL http://www.ucl.ac.uk/scholarly-communication/articles/beij.htm (20.10.2013).

Giddens (1990). The Consequences of Modernity. Cambridge: Polity Press.

Harley, B. , Dreger, M. , \& Knobloch, P. (2001). The Postmodern Condition: Students, the Web, and Academic Library Services. RSR: Reference Services Review, 29 (1), 23-22.

Kaufman, P. (2005). Role and Mission of Academic Libraries: Present and Future. URL https://www.ideals.illinois.edu/bitstream/handle/2142/123/ROLE\%20AND\%20 MISSION\%20OF\%20ACADEMIC\%20LIBRARIES.doc.pdf?sequence=6

Kirby, A. (2009). Digimodernism. How New Technologies Dismantle the Postmodern and Reconfigure our Culture. New York: Continuum.

Kruk, M. (2003). Truth and Libraries. Australian Library and Information Association. URL http://alia.org.au/publishing/alj/52.3/full.text/kruk.html (20.10.2013).

Laak, M. (2013). Heritage, User and the Digital Environment: Rewriting the Narrative of the Literary Past. In: The Digital Turn: User's Practices and Cultural Transformations. Frankfurt am Main [etc.]: PL Academic Research.

Lankes, R.D. (2007). Credibility on the Internet: Shifting From Authority to Reliability. Journal of Documentation, 64 (5), 667-686.

LeMoine, B. (2012). Nailing Jelly to the Wall: Understanding Postmodernism's Influence on Library Inormation Science. Library Philosophy and Practice, March. URL http://unllib.unl.edu/LPP/lemoine.htm (20.10.2013).

Lyotard, J.-F. (1997). The Postmodern Condition: a Report of Knowledge. Manchester: Manchester University Press.

Martin, P.N. (2009). Societal Transformation and Reference Services in the Academic Library: Theoretical Foundations for Re-Envisioning Reference. Library Philosophy and Practice, May. URL http://unllib.unl.edu/LPP/pamelamartin.htm (20.10.2013).

Owen, J.S.M. (1997). The Future Role of Libraries in the Information Age. In: International Summer School on the Digital Library, 10-22 August 1997, Tilburg University. URL http://eprints.rclis.org/5656/1/Future-role-of-libraries.htm (20.10.2013).

Postmodernism. (2002). URL

http://www.ellin.ttu.ee/ranno/postmodernism/index.html (15.09.2013). 
Ray, K. (2001). The Postmodern Library in an Age of Assessment. Proceeding of the 10th National Conference of the Association of College and Research Libraries, March 15-18, 2001, Denver, Colorado. URL

http://www.ala.org/ala/acrl/acrlevents/kray.pdf (10.09.2013)

Stone, S. (2000). Postmodern Approach to Organizing Information. URL http://www. du.edu/lisa/students/student_papers/sergio.htm (15.09.2013).

Viires, P. (2013). Digimodernistlik eesti kirjanik. Methis. Studia Humaniora Estonica, 8 (11). URL http://ojs.utlib.ee/index.php/methis/article/view/999 (01.11.2013). 


\title{
E-books in the Tallinn Central Library: First experiences
}

\author{
Triinu Seppam
}

\section{About the e-book lending service}

Our library started lending modern e-books in Estonian on 1 February 2012 one year and 10 months ago. The service is free of charge. Today the service can be used only by Tallinn Central Library users, because we are a municipal library, and we can only buy e-books with city funds, although about $50 \%$ of the total funding for books comes from the Ministry of Culture.

E-books can be borrowed 24/7, three e-books at a time. The loan period is 21 days, the same as for printed books. If the user forgets to return the e-book, the e-book "returns" itself after the due date. To read an e-book, the user has to have an Internet connection (it means that the user will not get to download the e-book file to his/her device) and use one of the newer browsers: Internet Explorer 9, Firefox, Chrome or the last versions of Safari. The user can read an e-book on his/her computer, on an iPAD or other tablet, on a smartphone or an e-book reader (for instance, a Sony e-book reader), which has a flexible web browser, and supports html5 and Javascript.

We provide e-book lending service through our own online lending and reading environment, which we call ELLU. ELLU is software which allows us to buy and lend e-books in the ePUB format, and allows our users to borrow and read e-books online. The library purchases a certain number of licenses ("virtual copies") of an e-book, and the number of licenses equals the number of users that can read the e-book at the same time.

Today e-book lending service has been used by more than 2,400 library users (as of 28.10.2013 - 2,452 users), who have made almost 14000 loans.

Although we are a municipal library, and our aim is to serve our community, we have also made this service available to Estonian schools in foreign countries and to children and youth under the age of 18 who live in areas where the Estonian communities are very small. As a result, students and teachers from New York, Washington, Dublin, Bologna, Cologne Munich, Stockholm, Shanghai, Taiwan and elsewhere have signed up to read e-books via ELLU. 


\section{Who reads e-books?}

It seems natural to associate e-books with children and youth. Jaanika Palm, a researcher at the Estonian Children's Literature Centre, recently provided advice in a popular news portal on how to get children to read books (Palm 2013). One suggestion was to use multimedia channels - audio books, movies and digital books - to promote children's interest in literature. However, are e-books only for young people? What do the ELLU statistics show us?

According to our statistics the audience is wider than just youth. Forty-two percent of the ELLU users were born between 1985 and 2009; 36\% between 1970 and 1984; and 19\% between 1950 and 1969.

Table 1 show how the statistics on ELLU users vary during one month.

Table 1. The dynamics of ELLU users in September and October 2013

\begin{tabular}{l|c|c|c|c|c|c|c}
\hline \multirow{2}{*}{$\begin{array}{l}\text { Year of } \\
\text { birth }\end{array}$} & $\mathbf{2 7 . 0 9 .}$ & $\mathbf{2 8 . 1 0 .}$ & \multirow{2}{*}{ Difference } & $\mathbf{2 7 . 0 9 .}$ & $\mathbf{2 8 . 1 0 .}$ & $\mathbf{2 7 . 0 9}$. & $\mathbf{2 8 . 1 0 .}$ \\
\cline { 2 - 5 } & Users & Users & & $\begin{array}{c}\text { Female } \\
\text { users }\end{array}$ & $\begin{array}{c}\text { Female } \\
\text { users }\end{array}$ & $\begin{array}{c}\text { Male } \\
\text { users }\end{array}$ & $\begin{array}{c}\text { Male } \\
\text { users }\end{array}$ \\
\hline $1920-29$ & 2 & 2 & 0 & 1 & 1 & 1 & 1 \\
\hline $1930-39$ & 17 & 17 & 0 & 9 & 9 & 8 & 8 \\
\hline $1940-49$ & 51 & 52 & 1 & 35 & 35 & 16 & 17 \\
\hline $1950-59$ & 140 & 145 & 5 & 98 & 103 & 42 & 42 \\
\hline $1960-69$ & 311 & 321 & 10 & 228 & 236 & 83 & 85 \\
\hline $1970-74$ & 254 & 265 & 11 & 183 & 192 & 71 & 73 \\
\hline $1975-79$ & 301 & 311 & 10 & 222 & 230 & 79 & 81 \\
\hline $1980-84$ & 294 & 309 & 15 & 242 & 255 & 52 & 54 \\
\hline $1985-89$ & 371 & 381 & 10 & 292 & 300 & 79 & 81 \\
\hline $1990-94$ & 262 & 271 & 9 & 196 & 205 & 66 & 66 \\
\hline $1995-99$ & 214 & 227 & 13 & 154 & 161 & 60 & 66 \\
\hline $2000-04$ & 125 & 138 & 13 & 90 & 99 & 35 & 39 \\
\hline $2005-09$ & 12 & 13 & 1 & 6 & 7 & 6 & 6 \\
\hline Total & 2,354 & 2,452 & 98 & 1,756 & 1,833 & 598 & 619 \\
\hline
\end{tabular}

We can see that the service has gained new users of all ages.

And an interesting fact: $75 \%$ of ELLU users are female. In his column in the Finnish magazine Kirjasto (Library), Jukka Relander, the President of the Finnish Library Association, wrote that men read more nowadays than they used to; they just don't use the library - they google and read texts online, because they are more interested in non-fiction (Relander 2013). It's difficult to comment on this statement - one thing is for sure, we need more research about reading. 
Of course, the statistics are totally different, when we examine people's reading habits beyond ELLU and outside the library. For instance, the Helsinki City Library conducted a survey at the end of February 2013 in which they asked people about their reading habits. In her presentation at the Nordic-Baltic conference, Marja Hjelt, an information specialist at the Helsinki City Library, explained that one out of five people in Finland have read e-books (in metropolitan areas, its one out of four) and $5 \%$ to $8 \%$ of ones who have read e-books, have used the e-book systems provided by Finnish libraries (although not all libraries offer e-books to their users) (Hjelt 2013). The survey also showed that half of those who have read e-books are only testing the service - this may also be the case with ELLU. Some people may only be testing the service. We do know that last year 1,404 people registered with ELLU and 464 of them have borrowed e-books this year - I think this number makes sense, because the selection of books in ELLU is still quite small.

\section{Shouldn't we just be buying more printed books and expanding the library's opening hours?}

On 28 October 2013, I took the 670 available e-book titles and analysed when people had last borrowed them $-60 \%$ of the loans were made outside of our library's opening hours, i.e. on Mondays after 7 p.m.; on other workdays after 8 p.m.; on Saturdays after 5 p.m.; or on Sundays.

Thirty-seven percent of the loans that were made outside of the library's working hours were made on Sundays. Fifty-eight percent of loans were made between 8 p.m. and 7:59 a.m.

Table 2. When e-books were borrowed

\begin{tabular}{c|c}
\hline $\begin{array}{c}\text { Time that loans were made outside of the } \\
\text { library's working hours }\end{array}$ & Number of loans \\
\hline $8: 00-8: 59$ a.m. & 11 \\
\hline 9:00-09:59 a.m. & 23 \\
\hline 10:00 a.m. $-7: 59$ p.m. & 134 \\
\hline $8: 00-8: 59$ p.m. & 33 \\
\hline $9: 00-9: 59$ p.m. & 48 \\
\hline $10: 00-10: 59$ p.m. & 48 \\
\hline $11: 00-11: 59$ p.m. & 53 \\
\hline 12 midnight $-12: 59$ a.m. & 25 \\
\hline $1: 00-1: 59$ a.m. & 10 \\
\hline $2: 00-7: 59$ a.m. & 15 \\
\hline Total & 400 \\
\hline
\end{tabular}


E-books have two more advantages, which people seem to forget - privacy when borrowing (other users don't see what you choose from the shelf) and safety (the opportunity to borrow literature at 11:30 at night in a safe environment, from your home).

\section{About the challenges ahead}

Our library has signed the following agreement with the Estonian Publishers' Association (it is optional for the publishers): an e-book "can be borrowed 35 times under one licence" and thereafter the library must buy a new licence; the price for a licence (for lending out the book 35 times) is the retail price; the publishers can sell us an e-book 3 or 6 months after the e-book has been published, or never (for instance, if they don't get the author's consent, they can't sell it to us; or they think that the library would damage sales).

The UK publisher HarperCollins claims that the average library book is replaced after being loaned out 26 times, and this should also apply to e-books. I hope that this model will not be implemented in Estonia, although we have heard publishers talking about it. The HarperCollins model is only one of many that are used in other countries.

Today, if we want to buy an e-book, we make a request and compile a list of the e-books we want to buy, and send it to the e-book manufacturer (for instance, the Estonian Digital Books Centre). The manufacturer then asks the publisher for permission, and thereafter lets us know which e-books we can buy and which we can't. Sometimes we have to contact the publishers and authors directly. It is not always easy to get a licence to lend e-books - it takes time, and for different reasons, some e-books will never find their way to ELLU.

The fact that the authors and publishers can decide not to sell e-books to libraries can increase social inequality. So I think that the biggest challenge is the Copyright Act, and the European Union's Information Society Directive of 2001, which don't recognise new IT solutions and say that e-books are not books (Linask 2013). This directive is the reason why libraries all around the world are struggling with different e-book lending models. Many of these models are too expensive for libraries. But I think that the worst possible model is asking the library user to pay for borrowing e-books.

The Estonian Digital Books Centre has managed to get us the rights to lend more than 600 e-book titles in Estonian via ELLU, and currently at the same retail price as everyone else. The second largest company in Estonia - DIGIRA - has refused to sell us e-books for different reasons.

In 2012 we bought e-books only from the Estonian Digital Books Centre, from 31 publishers in total. We didn't get consent to lend 85 titles, which is $17 \%$ of our requested titles; $55 \%$ of which was literature written by Estonian authors. We got negative responses from 15 publishers. 
In 2013 we have asked the Estonian Digital Books Centre for 220 titles and haven't received 34 titles $(16 \%)$. If we include those titles and the books that we have requested from DIGIRA (altogether 371 titles), the statistics are quite depressive. We haven't received $59 \%$ of the requested titles; $63 \%$ of which were written by Estonian authors.

We have also tried to get new licenses for the titles that have expired. We got negative answers for 26 titles; $92 \%$ of which were written by Estonian authors.

As long as there are two copyrights (one for print books and one for e-books), it's not clear how libraries are going to purchase e-books in the future. Today, if the library lends out a printed book, the author gets paid for the loan from the Estonian Author's Benefit Fund, but this doesn't apply to e-books that are borrowed via the Internet. Therefore, we proposed a compromise solution - the library will buy another licence for an e-book after it has been lent out 35 times, and the author will get the money from that sale. It would be very helpful if the Estonian Author's Benefit Fund would also pay for e-book loans.

And, of course, there's also the VAT issue. Today there are two different value added tax rates in Estonia: one for printed books, which is 9\%, and one for e-books, which is $20 \%$, because according to the law, an e-book is not a book, but a service.

France and Luxembourg, which have passed laws that tax the e-books downloaded from the Internet at the low VAT rate since January 2012, have now been sued by the European Union (Taxation ...2013). In my opinion the VAT rate for both printed books and e-books should be the same. Both of these formats serve the same purpose - reading and knowledge.

\section{References}

Hjelt, M. (2013). Finns'wishes and opinions of libraries e-resources. Nordic-Baltic conference material, 13.09.2013.

Linask, K. (2013). Raamatukogud ei soovi e-raamatu-alast segadust ja ebakindlust. Raamatukogu, 4.

Palm, J. (2013). Kaheksa head nõuannet, mille abil saad oma lapsed lugema ka kõige igavamaid raamatuid! Delfi, 14.10.

http://naistekas.delfi.ee/perekond/vaikelaps/kaheksa-head-nouannet-mille-abil-saadoma-lapsed-lugema-ka-koige-igavamaid-raamatuid.d?id=66903835_(17.10.2013)

Relander, J. (2013). Mieslaskeuma. Kirjasto, 2.

Taxation: Commission refers France and Luxembourg to the Court of Justice over reduced VAT rates on e-books (press release on 21.02.2013).

http://europa.eu/rapid/press-release_IP-13-137_en.htm (30.10.2013). 


\title{
Exciting reading from the past: Archiving and usability of the periodicals stored in the digital collections of the National Library of Estonia
}

\author{
Krista Kiisa
}

Reading, in its very different forms, is definitely a part of the Estonian lifestyle. And not only in the form of reading books from cover to cover, but also the very different aspects of reading periodicals. I am not referring to the wellknown habit of reading the latest breaking news from the front page of a newspaper's website. Rather, I am talking about the user behaviour which we have noticed, working with periodicals in the National Library of Estonia (National Library) - acquiring data from publishers and disseminating it to our customers via our digital archive DIGAR. (http://digar.ee)

Firstly, about the methods we use to collect periodicals for our digital archive.

\section{The workflow for current periodicals}

The National Library's priority in working with periodicals is to acquire and archive the print files of currently published material. The current Legal Deposit Act in Estonia applies to printed materials and web publications, but not to electronic print files. Although the Legal Deposit Act allows us to collect and archive web publications, we do not have the resources to extensively harvest dynamic data from the newspapers' websites. And as the content published on the Web usually differs totally from the content on paper, it was decided that greater efforts should be made to clarify the following message to the publishers: it is useful for you to archive the print files of your paper edition in the National Library. Since the law does not support us, we had to rely on the goodwill of the publishers in the negotiations and the valuable experience it provides to the publishers regarding the future legal deposit system, which we hope will come into force in 2014 with the amended Legal Deposit Act. 
We already started negotiations with the largest daily newspaper Postimees in 2007 and received surprisingly positive feedback. The first print files (starting retroactively from 2006) started to arrive in our ftp-server during the same year. The supply was not as regular and technically proper as we had perhaps hoped, but the first steps were taken. This first attempt served as a test case with a well-known publisher, which made it much easier to start convincing the other publishers. Over the next several years, we were able to convince nearly half the newspaper publishers to send us their print files voluntarily. It was a good start.

But you cannot expect the readers to be interested in your collection unless the material offered is comprehensive and current. Proceeding from that assumption, we wanted to have the current periodicals deposited in the library not at some time during the day or week, not after several reminders, but early in the morning before the workday started. Facing financial difficulties, the library could save a lot of money by not having to purchase several additional paper copies for library users who come to the library to read the latest news. In addition to our own daily work compiling the Database of Estonian Articles, in which about 200 articles are added to the database each day. Why not use the electronic print files, which would be ready starting at 8 am, eliminating the need to buy several extra paper copies? The key here is to provide the readers with a means to browse and search.

In autumn 2012, we faced a situation where the new Legal Deposit Law had not yet entered into force, and we lacked the resources to work case by case with all the publishers. That was the starting point for negotiations with the Estonian Newspaper Association (EALL). Currently, the EALL unites 40 newspapers published in Estonia, with a total daily circulation of 510,500 copies. The EALL was very interested in cooperating after it was made clear that both parties could benefit from such collaboration.

The Estonian Newspaper Association supports the idea that we should archive the electronic print files, and send the publishers their files if and when they need them. Even more, the EALL saw that this was business model they could use - the opportunity to use the National Library's server as an intermediate station where media monitoring companies, with licences from the EALL, could download the print files for their commercial use.

It was decided to immediately open all the electronic print files for use on the premises of the National Library. This is something we definitely cannot retract under any circumstances. The people, who make the effort to come to the library to read the periodicals - and there are still many who do - must get access to all of them. The restrictions on access to broader online use are determined by the publishers: it is their right to determine these restrictions for the public.

Today we have 41 newspaper publishers who send their newspaper print files to our archive daily for a total of 110 titles. This means that we receive 
about $99 \%$ of the currently published daily and weekly newspapers at the same time that they are sent to the printers - hours before they actually come on sale. This number does not include the so-called "small" newspapers published by schools, churches, institutions, organisations, different societies and companies. Currently there are 342 such titles in Estonia, and this is a field of activity that is waiting for its turn.

As far as the users' reading habits, there are people who like to browse and those who like to search. In the electronic environment, users no longer read newspapers page by page from the front page to the obituaries, even when reading the print files in pdf format. Even more, I dare say that they sometimes do not read the entire articles. Due to a lack of time, they expect to extract the information based on a specific subject flow or area of interest.

The average user likes to browse, and not only in the latest issue. The newspapers in the library's digital archives are also actively browsed weeks after they are published. Considering the increasing popularity of smartphones and tablet computers, this trend will apparently grow.

At the same time, more advanced users like to search among a large amount of well-systematised material. Our task is to support these users and keep them using our collection. We will probably be more successful at this, if we can reduce the gap in time between the publication and processing of the published material in our database.

Having kept an eye on the user behaviour related to the library's digital archive, I would venture to say that the use of the digital archive does not harm the publisher's commercial interests in any way. Firstly, the readers using our portal are more in the need of accurate search results based on older rather than more recent news. On the other hand, the overall market in Estonia is so small that it is very difficult for publishers to make a profit from selling newspapers that are more than 1 or 2 weeks old. But for the library and our readers this is still valuable material.

The everyday users do not appreciate the library's goal of permanent preservation. If they cannot get the material they want; if the material is locked and can be access only at the National Library, they are disappointed in both the newspaper and DIGAR. This is obviously not a good platform for developing new services for the National Library users.

\section{Web harvesting is another work process being actively developed}

Currently we are using a selective method for registering and archiving the publications on Web. The archiving activity operates according to the Legal Deposit Act, which as been in force since 2006. 
The general criteria for selecting and archiving online materials are the following: their publication, identifiability, exhaustiveness, long-term and permanent value, and place of publication (based on the publisher). All these criteria were decided by the Working Group of Web Archiving Experts - a joint advisory body comprised of members from the leading memory and research institutions. The goal of the working group is to provide advice on how to select material for archiving. The broad-based working group also represents the interests of current and future researchers and potential everyday readers of the interface. Since it is impossible to foresee what will be important for future researchers and users, it is necessary to harvest a snapshot of the entire Estonian national Web. There are plans to harvest exclusively Web-based periodicals based on their frequency of publishing starting in 2014. We expect to satisfy quite an extensive user interest towards that interface.

Last but not least - the oldest activity at the National Library of Estonia is the digitisation of historic newspapers, which we have been doing in cooperation with the Archival Library of the Estonian Literary Museum and the Academic Library of Tallinn University.

The digitisation of older newspapers is done predominantly from the microfilms that were made in the early 1990's. This means that the quality of the scanned images is often quite poor. Unfortunately, this is our only option. Due to the very complicated history of Estonian library holdings after World War II, no library in Estonia currently possesses a complete hard-copy newspaper collection. The nearly complete microfilmed/digitised collection is the result of cooperation during which single physical copies were gathered in the 1990's from various libraries for short-term microfilming purposes and are now accessible at http://dea.nlib.ee

This is probably one of the reasons why it is so actively used by the readers. The digital collection is the most comprehensive one. At the moment it is still an image database where searching is possible only by title and date. Although there is no full-text search available yet, it is still being quite actively used.

There are 380 titles with a total of 1.3 million pages, most of which are in Estonian. About 300 individual visits are made to the database every day. Although it is said that Estonians are stingy with compliments, it is quite the opposite with the users of old newspapers. Despite the fact that they can only view a rather poor quality image in the DEA with no full-text search, they give us very positive feedback! Our next plan is to use OCR and run the article segmentation on these pages. The activity was started thanks to the European Newspapers project. This is a great opportunity to gain knowhow from our project partners and gives us the possibility to use OCR and run article-level processing for half of our digitised newspaper images.

Currently, there are three different databases in three different places that the users must search if they want to find periodicals. This is something we want to change in the very nearest future. Therefore, we plan to acquire portal 
software in order to provide a single point of access to all the newspapers historic digitised, current print files or those harvested from the Web. The current plan is to open the new newspaper portal in 2014. We also plan to enable crowd-sourcing there, as we hope it will increase the popularity of the archive and, with the help of our users, we can improve the current quite poor OCR result obtained from scanned images on microfilm.

Speaking of the most popular periodical titles I would like to highlight the journals digitised in cooperation with the publisher Kultuurileht. After going online in 2012, its journals Akadeemia and Looming have been attracting a continually increasing number of user visits every month. The older annual sets of Looming are digitised and accessible from the very first issue in 1923.

Despite the fact that periodicals very quickly become "old news", I'm convinced that they continue to be and have the right to be at the forefront of digital library developments and should also be available on the users' desktops. 


\title{
Prima Vista Literary Festival: The message delivered by libraries in space and time
}

\author{
Ilona Smushkina, Elena Sipria-Mironov
}

\section{The role of libraries in the promotion of reading}

Libraries are in a perfect position to encourage the reading habits of their users. At the same time, the role of libraries in the society has changed. If some time ago they could be described as book banks, libraries are now performing the functions of open information and cultural centres. Today, libraries are safe, non-commercial and very open social institutions where everybody is welcome regardless of their social status, education, age, income or nationality.

Like public libraries, academic libraries also need to provide their readers with advice. The university community needs these services more than ever, as the electronic resources and means of communication employed by students increasingly distract their attention. After looking back at the history of academic libraries in the 20th century, there is a strong need to encourage reading among the users, by including programming, connecting with other libraries, expanding ideas of genre, and developing the readers' advisory skills (Smith $\&$ Young 2008). In an attempt to promote literacy, many academic libraries are trying to implement reading programs. In order to encourage reading among their students, some libraries have organised book talks and reading groups to provide common reading experiences; some have started book clubs that meets monthly and serve the university community as a resource that encourages reading for pleasure and enrichment. Other libraries participate in communal reading programmes on their campuses; book discussions are held at various times and locations on campus to include as many students, faculty and staff members as possible (Hillery \& Henkel 2010).

Today, probably no one doubts the need, importance and essential nature of reading on an individual scale, as well as in respect to the entire state or even the world. Reading has been an inseparable part of everyday life for Estonians 
for some time. Books are important to people and have been the central cultural medium in Estonia. A large number of Estonians, as well as Russians living in Estonia, continue the traditional book-centred way of experiencing culture. At the same time, for the younger generations books have become secondary compared to electronic media when seeking aesthetic experiences (Lõhmus, Lauristin \& Salupere 2004). The reading habits of people can change in time, but letters, words and texts remain. Reading has changed its 'way of being' and the task of the libraries is to keep pace with these changes. Libraries have had a certain meaning throughout the centuries. Libraries, founded as initiatives by people, were established to satisfy the need for education and culture. Today a library is still an environment that promotes thinking and the enjoyment of privacy. It is a place where the reader and the writer can meet; a place where a great deal of work is done to ensure that children and youngsters will continue to be interested in books and reading. It is also a cultural centre where different cultural and educational events take place.

\section{How did we come up with the idea of a literary festival?}

In order to preserve social demand, libraries have to meet the needs of the readers and use the feedback they receive in organising their work. At this point we should describe a survey carried out by the Department of Public Relations at the University of Tartu Library in 1999. The survey had a purely pragmatic aim - to learn what the readers expect, to decide how to plan further activities, which events to organise, and how to use financial resources more efficiently. A questionnaire was compiled for the library users and 400 copies were handed out, of which, more than 350 were returned with answers. The survey showed that most people come to the library to study and to borrow books. At the same time, the readers tend to do many things while using different services during a visit. Many of the people who participated in the survey also use the library as a place to meet friends and spend time. At that time, we were sad to discover that the events organised at the library were not well-attended. The answers to the questionnaire also showed the paradoxical reason; i.e. the readers did not perceive the events organised by us as library events.

We also became convinced that we must learn more about the people who have participated in our events, have organised conferences and seminars at the library, or assisted us with the exhibitions. Thus, in addition to the user questionnaire, we also organised a focus group interview. The focus group included 14 people from the University of Tartu, among them a philologist, lawyer, biologist, historian, philosopher, lecturer on social work, doctor and economist from a professor emeritus to the chairman of the student council. In addition, a 
head of the Tartu Art College, a member of Tartu City Council, the Tartu Public Library director, a writer, and a politician agreed to participate in the focus group interview.

The respondents of both surveys assessed the book presentations, meetings with writers, scholars or politicians, book sales organised by publishers, etc. It turned out that book sales were the most popular, although the events related to art and music were also mentioned. Joint projects with other cultural institutions and publishers were regarded as successful and interesting. We were also interested in whether the library had managed to preserve its good reputation among those who matter the most to us - the academics and the students. The feedback of both user groups confirmed that "There is no better place and no better audience in Tartu". A few more examples of the typical answers:

\footnotetext{
"It is truly one of the places where the spirit of Tartu exists, its importance cannot be overestimated."

"The library has grown together with the University of Tartu, which has been and probably will remain the most important intellectual centre of Estonia for a long time."
}

In order to meet the expectations and needs of library users and use the financial resources most efficiently, we made some changes in the ways we organise the events at the library. We began to apply for funds from different foundations, decided to organise less rather than more events, but at the same time, to make these events larger. We started organising the UTLIB Market Book Fair in the spring, which quickly became a very popular event and which can also be considered to be the predecessor of the Prima Vista Literary Festival. In a few years, translating seminars, meetings with writers, exhibitions of book illustrations, workshops and other events were taking place during the book fair. At the same time, the Tartu Public Library organised the Park Library, concerts by singing writers and other events for readers. The Tartu Department of the Estonian Writers' Union and the Estonian Literary Society also became very active. In 2003, the representatives of all these organisations came together at our library to discuss the idea of organising a literary festival and thus the development of a network of Tartu's literary institutions began. It should not be overlooked that, right from the beginning, the Tartu City Government provided moral and financial support.

Therefore we can say that the library users, as well as the actions of other organisations, but also our own aspirations and even financial troubles, have affected the birth of this great literary festival. 


\section{From idea to reality}

The first Prima Vista Literary Festival was greatly praised by the public - it was awarded the title of Cultural Event of the Year in Tartu. Already in 2005, when the extensive survey entitled Tartu - European City of Culture was conducted, it showed that the Prima Vista festival was greatly appreciated by the audiences (Vihalemm \& Keller 2005). This survey also included suggestions for improving the festival's public communications, which were subsequently taken into account. In 2010 the festival's organising committee won the Culture Carrier Award as Producer of the Year in Tartu.

The main programme takes place during the second week of May, but there are many warm-up events before the festival, as well as events that take place after the official programme has ended. The World Book and Rose Day is celebrated on April 23rd as a warm-up event, and it has become almost as big as the entire festival was during the first years. The festival also awards a yearly literary prize called First Step for the best fiction debut - the winner of the prize is announced during the celebration of the Book and Rose Day.

Festival programmes need a symbolic creative space, which unites the cultural institutions, the organisers of the event and the usual social meeting places creating synergy, which stimulates and offers new impulses, affecting the culture of the whole city (Richards \& Palmer 2010). Thus, the events which focus on local culture or traditions are the most common means for giving a place meaning and strengthening its identity. Every year the Prima Vista Festival organises more than 100 different events during one week, with the events varying from meetings with writers to fashion shows. All of this comprises an extensive springtime event that arouses interest, not only among the citizens of Tartu, but also throughout Estonia. More than 100 performers from various countries participate every year, and the festival has attracted about 15,000 people altogether. The programme includes meetings with writers, poetry readings, book presentations, workshops, films, theatre performances, concerts, conferences, seminars, competitions, art and book exhibitions (usually about15 exhibitions).

As mentioned above, the festival grew out of the UTLIB Market Book Fair, which was organised for the first time by the University of Tartu Library Festival in 2002. Today, the fair is the largest book fair in Southern Estonia with more than 30 publishers participating every year. There is also a second-hand book fair, which gives people the opportunity to find rarer or cheaper books. Book presentations, meetings with the writers and other events are, of course, parts of the fair programme. In addition to the book fair, the Park Library, which is organised by the Tartu Public Library, has also remained a traditional event. This open-air library offers an opportunity for all the passersby to stop by and even to borrow books, since there is also a registration desk where they can easily become library users. As a real library, the Park Library offers much 
more than just an opportunity to borrow books. People can play board games and use the Internet; and there are also many events, the most popular of which is the concert of the singing writers. In July 2013, a CD called Lutsuvad Kivid was released with the songs that have been performed by various writers during these concerts since 2005. Most of these authors have participated in the festival for many years.

There is also a children's programme. This usually includes around 20 events for children of different ages who can participate in workshops, meet the writers, as well as take part in literary tours and orientation games. An event called "Grandma in the Apple Tree" is worth special mention, as it is a family event for children and grandparents, who come to the library to read and play games together.

\section{The relationship between the festival and the local community}

Festivals provide a positive cultural influence, contribute to a community's individuality and identity, improve the cohesion and quality of community life and enable individuals to improve their personal welfare through acknowledgement, socialising and cultural development. The organisers' reactions to the attitudes of the community, cooperation between the organisers of the festival and the local people can improve the communications between the local community and the guests of the festival, which increases the benefits of both parties and is the basis of success of every festival. (Delamere 2001). This very diverse programme is a result of cooperation - during the last 10 years Prima Vista has had many partners, including the Finnish Institute, the German Institute, the Polish Embassy, the Hungarian Institute, different departments of the University of Tartu, the Estonian National Museum, Tartu Toy Museum, schools and day-care centres, the literary magazine Värske Rõhk, the Estonian Librarians' Association, the movie theatre Tartu Elektriteater, the Tartu Uus Teater (Tartu New Theatre), Tartu Art College, other festivals such as tARTuFF and Mailaul, and many other organisations. Prima Vista also collaborates with bookshops and even shopping centres, such as the Tartu Kaubamaja, to stage literary events in as many different places and as many different forms as possible. Therefore Prima Vista is constantly expanding its presence in the city space and providing opportunities to meet and socialise; to participate in literary life that is not meant only for the so-called "literary circles", students and academics, but for everybody interested in literature. The festival connects people of different ages and nationalities, who have different interests, tastes and social status. 
Every year the organising committee works out a main theme or slogan, which, in the past, has included "The Last Days of Libraries?", "The Art of Survival", "Change of Course", "Room ID", and "Time Flies!" The festival also has a patron. Every year the organising committee asks a renowned Estonian writer, critic or cultural figure to be the festival's patron. The past patrons include Rein Veidemann, Arvo Valton, Indrek Hirv, Doris Kareva, Andres Ehin, Rein Raud, Hannes Varblane, Leelo Tungal, and Mihkel Mutt.

Prima Vista also introduces the literature and culture of other peoples and contributes to the integration of and communications between different ethnic groups. Thanks to a long-term partnership with the representative institutions of different countries, the festival has attracted guests from Hungary, Finland, Poland, Latvia, Spain, the U.K., U.S., France, Germany, etc. (Their performances in Estonia have been supported by the respective institutes, embassies or councils.) One of the most memorable events was the visit of the writer, philosopher and publicist Umberto Eco; the festival has also been visited by German musician and poet Wolf Biermann, British punk poet John Cooper Clarke, American cyberpunk classic Bruce Sterling, Finnish writer Joel Haahtela, Hungarian writer Attila Bartis, and many others. From the beginning, one of the aims has been to integrate the local non-Estonian communities. Thus, the local Armenian, Ukrainian and Jewish communities have introduced their culture and literature at Prima Vista. There is a noticeable focus on the Russianspeaking audience, as this is the largest non-Estonian community in Estonia. Every year Prima Vista has a special programme in Russian and the traditions of Slavic studies at the University of Tartu play an important role in the formation of these sub-programmes. Renowned Russian writers such as Lyudmila Ulitskaya, Dina Rubina, Aleksandra Marinina, Dmitri Bykov, Grigory Oster, Jevgeni Griškovets, Leonid Mlechin, as well as internationally renowned translator and publisher Elena Kostioukovitch have visited Prima Vista. One of the traditions involving the Russian guests are the informal meetings organised at a bookshop in the city centre which specialises in Russian-language literature - the Russian-speaking intellectuals come together to have a cup of tea and meet the guest. The discussions revolve around writing, history and politics, as well as the personal lives of the guest writers. Intriguing political issues, relations between Estonia and Russia, as well as the views and ideas of the creative people turn these meetings into very passionate and unforgettable experiences; and the feedback from the local Russian intelligentsia has always been very emotional and grateful. At the same time, it should be stressed that main reason for inviting the writers from Russia to the festival is to bring Russian culture closer to the Estonians, by introducing the best representatives of Russian literature to Estonian audiences. Both the Estonian readers, as well as writers, have provided very positive feedback about the Russian programme at Prima Vista. There have always been many Estonians at the events involving the Russian 
writers - partly because the discussions are often moderated by renowned Estonian writers, critics, translators and academics.

Every year the Prima Vista programme can also be enjoyed in some other Estonian town. The partner-town programme is always coordinated by the central library of the respective town, which is often the main cultural centre of its region. Our partners have included Narva, Pärnu, Viljandi, Põltsamaa, Võru, Elva, and Valga, along with the people from the libraries in these towns. The tasks of the partner library include organising a part of the programme, communicating with the local government and finding the financial resources for the partner-town programme. As Prima Vista is a major literary event renowned throughout Estonia, the partner towns usually receive the support they need from the local governments. The Prima Vista organising committee provides advice and support, and invites the patron as well as some of the foreign guests and Estonian writers to appear in the partner town. The role of libraries in the local cultural life is very important today and major cultural events give them an opportunity to highlight their social role in the community.

\section{In conclusion}

Throughout the centuries, the University of Tartu Library has had a special role in the history of Estonian society, culture and science. The intellectual environment of the university town has been, and most probably will remain, a challenge and a yardstick for the activities of our library.

Let's try to be honest, at least to ourselves - what is the social role of libraries in a contemporary society and cultural space? In our very pragmatic era, this question poses a major challenge to us. The rapid development of information technology undoubtedly provides new directions of development for libraries, but at the same time, it requires that new ways of communicating with the potential readers be found. For us, one of these ways is the Prima Vista Literary Festival. We are convinced that the University of Tartu Library must not only support the scholarly work and teaching processes of the university, but it also needs to contribute to shaping the intellectual community of Estonia.

\section{References}

Delamere, T. (2001). Development of Scale to Measure Resident Attitudes Toward the Social Impacts of Community Festivals, Part 2: Verification of the Scale. Event Management, Vol. 7(1), 25-38.

http://lin.ca/sites/default/files/attachments/CCLR9_11.pdf

Hillery, L.B. \& Henkel, H.L. (2010). Literature, Community and Cooperation: The Big Read at Regent University. Public Services Quarterly, 10(6), 331-342. 
Lõhmus, M., Lauristin, M. \& Salupere, R. (2004). Inimesed kultuuriväljal: aktiivsus ja eelistused (People on the cultural field: activity and preferences). V. Kalmus, M. Lauristin \& P. Pruulmann-Vengerfeldt (Eds.), Eesti elavik 21. sajandi algul: ülevaade uurimuse Mina. Maailm. Meedia tulemustest. Tartu: Tartu Ülikooli Kirjastus.

Richards, G. \& Palmer, R. (2010). Eventful Cities: Cultural Management and Urban Revitalisation. Oxford: Elsevier.

Smith, R. \& Young, N. (2008). Giving pleasure its due: Collection promotion and readers' advisory in academic libraries. The Journal of Academic Librarianship, 34(6), $520-526$.

Vihalemm. T. \& Keller. M. (2005). Tartu - Euroopa kultuurilinn. Kirjandusfestival "Prima Vista", 5.-6. mai, 2005, Tartu. Publiku ja osalejate tagasiside uuring (Tartu an European cultural center. Literary festival Prima Vista. Feedback research of the audience and participants). Phare CBC 2002 programm, Tartu Ülikool.

http://www.tartu.ee/data/3_Prima_Vista_publiku_tagasiside0.pdf 